Cristina Banks-Leite

Conservação da comunidade de aves de sub-bosque em paisagens fragmentadas da Floresta Atlântica

São Paulo

2009 


\section{Cristina Banks-Leite}

\section{Conservação da comunidade de aves de sub-bosque em paisagens fragmentadas da Floresta Atlântica}

Tese apresentada ao Instituto de Biociências da Universidade de São Paulo, para a obtenção de Título de Doutor em Ciências, na Área de Ecologia.

Orientador: Jean Paul Metzger

São Paulo

2009 


\section{Ficha Catalográfica}

\section{Banks-Leite, Cristina}

Conservação da comunidade de aves de sub-bosque em paisagens fragmentadas da Floresta Atlântica.

Número de páginas: 227

Tese (Doutorado) - Instituto de Biociências da Universidade de São Paulo. Departamento de Ecologia.

1. Efeitos de borda 2. Perda de habitat 3. Indicadores de biodiversidade I. Universidade de São Paulo. Instituto de Biociências. Departamento de Ecologia.

\section{Comissão Julgadora:}




\section{Dedicatória}

Aos meus pais e irmã, pelo apoio incondicional 


\section{Agradecimentos}

Agradeço ao Conselho Nacional de Desenvolvimento Científico e Tecnológico (CNPq) pela bolsa de doutorado e financiamento da pesquisa de campo, e à Coordenação de Aperfeiçoamento de Pessoal de Nível Superior (CAPES) pela bolsa de doutorado sanduíche. Agradeço também às diversas instituições e universidades pela disponibilização de infra-estrutura que tornaram este trabalho possível: Departamento de Ecologia/USP, Silwood Park/Imperial College London, SELVA e BIOCAPSP.

Agradeço ao Dr. Jean Paul Metzger pela orientação, apoio financeiro constante, vasta infra-estrutura disponível, vários incentivos, muita paciência, tremenda confiança e muitos, mas muitos, ensinamentos. Mas principalmente agradeço pela amizade tão querida durante estes anos todos.

To Dr. Robert Ewers for hosting me in his lab for one year. What started as a project to analyse one chapter became a joint collaboration of six manuscripts. But mainly, for sparing the time, and patience, to teach me the whole process from data analysis to manuscript submission.

Aos Doutores que, com um pequeno comentário ou com horas a fio de conversas, aumentaram consideravelmente a qualidade deste trabalho: Renata Pardini, Luís Fábio Silveira, Pedro Develey, Raph Didham, Paulo Inácio Lopes, Jos Barlow, Toby Gardner, Ale Uezu, Val Kapos, Erica Hasui, Guy Pe’er, Mick Crawley, Cagan Sekercioglu, Bill Laurance, Astrid Kleinert.

Às 33 pessoas que me ajudaram no trabalho de campo! Ao Danilo Boscolo (agora Dr. também!) por me ensinar o básico do básico em direção 4X4 off-road, e como trabalhar em uma paisagem fragmentada. Carlos Candia (Kiwi), e Adriana Bueno, por terem me ajudado a descobrir todos os proprietários e, junto com Bastião, ter desbravado as matas de Tapiraí. À Renata Pardini por ter ajudado tanto durante meus enlouquecimentos pra organizar o campo. A Rafael Pimentel, Erica Hasui e Kiwi por agüentar condições inumanas de trabalho de campo, chuva, sol, frio, calor, carrapato, berne, fome e todas as outras intempéries possíveis e imaginárias. Mas principalmente gostaria de agradecer a Celso Henrique Parruco e José Roberto Mello Jr. (Magrão) por terem permanecido nestas condições do começo ao fim e terem se tornado braço direito, esquerdo, pés e cabeça. As constantes brincadeiras, músicas de altíssima qualidade e muitos ensinamentos sobre a vida na roça, mantiveram minha sanidade mental durante o trabalho de campo; mas foi pelo companheirismo da divisão de trabalho físico e mental e da completa confiança que tenho em Celso e Magrão que estes dois se tornaram amigos pra vida. 
A Laura Naxara, Paula Lira e Daniela Bertani por terem sido colegas de trabalho e ótimas amigas. Difícil dizer onde o trabalho termina e a amizade começa, mas sei que estas três mulheres incríveis me ajudaram no trabalho de campo, análises e escrita e foram amigas maravilhosas durante boa parte do meu caminho pela USP.

Aos colegas de laboratório pela companhia e ajuda em diversos momentos, Miltinho, Rafa, Kiwi, Marcelo, Simone, Mari Dixo, Thais Olitta, Thais Condez, Tank, Robertinha, Fabi, Cintia, além dos já saídos Ana Maria, Danilo e André. E especialmente ao Leandro, pelos mapas, e ao Welington por inúmeras ajudas com o(s) computador(es)! E aos amigos que simplesmente tornaram a vida mais divertida e fácil nestes anos, Elliot, Rodrigo, Maria Cecília, Karl, Luis Arthur, Dede, Miguel, Pluck, Kirsten, Lika.

À Dra. Astrid Kleinert, Dr. Márcio Martins, Dalva Molnar e Bernadete Poli Preto por todo o apoio durante minha passagem pela Pós-Graduação como representante discente.

A todos os proprietários de Tapiraí que gentilmente cederam suas casas e sítios para que este trabalho pudesse ser conduzido. Agradeço também aos funcionários da CBA por estarem sempre dispostos a ajudar no que fosse preciso.

A meu pai, mãe e irmã, a quem dedico esta tese, por terem sempre dado todo o apoio e estímulo do mundo! Agradeço também à Luci, cuja escolha profissional serviu como exemplo e que também sempre apoiou e torceu desde o começo. E claro, ao Fabrício, que ajudou a tornar estes anos mais agradáveis e divertidos!

And finally to Rob, my greatest love, to whom I'm dedicating the rest of my life. 


\section{Índice}

$\begin{array}{ll}\text { Resumo } & 01\end{array}$

$\begin{array}{ll}\text { Summary } & 02\end{array}$

Capítulo 1. Introdução geral 03

1.1. Introdução 05

1.2. Objetivos 13

1.3. Áreas de estudo 16

1.4. Método de amostragem de aves de sub-bosque 21

Capítulo 2. Ecosystem boundaries 31

Resumo/Summary 34

2.1. Introduction 36

2.2. Diversity in habitat edges 41

2.3. Abiotic changes and their effects on ecological processes at edges $\quad 43$

2.4. Mediation of cross-system flows 45

2.5. Species interactions 47

2.6. Conclusion 48

Capítulo 3. Edge effects as the principal cause of area effects on birds in fragmented secondary forest 59

$\begin{array}{ll}\text { Resumo/Summary } & 62\end{array}$

3.1. Introduction 64

3.2. Methods 67

3.3. Results 73

3.4. Discussion $\quad 75$

Capítulo 4. Disentangling the confounded effects of habitat loss, configuration and quality on bird communities of the Atlantic Forest 93

Resumo/Summary 96

4.1. Introduction 98 
4.2. Methods

4.3. Results

4.4. Discussion

Capítulo 5. Temporal sampling protocol influences the detection of ecological patterns

Resumo/Summary

5.1. Introduction

5.2. Methods

5.3. Results

5.4. Discussion

5.5. Supplementary Material

Capítulo 6. Comparing the use of species and structural measures as indicators of ecological integrity

Resumo/Summary

6.1. Introduction

6.2. Methods

6.3. Results

6.4. Discussion

6.5. Supplementary Material 


\section{Resumo}

Florestas tropicais comportam dois terços de todas as espécies existentes no mundo, mas a perda de habitat, fragmentação e alteração na qualidade do habitat estão levando esta biodiversidade à extinção. Apesar de haver uma extensa literatura sobre este assunto, há um consenso geral de que o conhecimento gerado por muitos estudos é dependente do contexto e permeado por dificuldades metodológicas, como a alta correlação entre os fenômenos ocorrentes em paisagens alteradas pela ação humana e a miríade de respostas biológicas encontradas entre espécies. Desta forma, há ainda muita incerteza sobre a generalidade dos padrões observados e sua efetiva aplicação para a conservação de áreas naturais. Assim, nesta tese o objetivo foi de contribuir para esta discussão ao responder as seguintes perguntas: (i) Qual papel que bordas ecossistêmicas e efeitos de borda desenvolvem em comunidades naturais? (ii) A comunidade de aves é afetada pela fragmentação do habitat de maneira semelhante em matas primárias e secundárias? (iii) Seriam os efeitos de área e de borda análogos, e estariam estes associados em uma relação causal? (iv) Como a comunidade de aves se comporta com relação à variação na cobertura florestal, configuração do fragmento e qualidade do habitat, e será possível separar o efeito de cada variável? (v) Diferenças no protocolo amostral poderiam alterar as estimativas de atributos da comunidade e mudar a magnitude dos padrões ecológicos observados assim como a probabilidade de detectálos? E (vi) qual estratégia é mais eficiente em identificar locais com alta integridade da comunidade, espécies indicadoras ou métricas indicadoras, como métricas da paisagem? Para responder estas perguntas foram usados dados provenientes de mais de 7000 aves capturadas com redes de neblina em 65 pontos amostrais localizados em seis paisagens de diferentes proporções de cobertura florestal e graus de perturbação na Mata Atlântica do Planalto Atlântico Paulista. Os resultados mostram que: (i) bordas estão presentes tanto em habitats naturais quanto alterados pela ação humana e produzem grandes efeitos sobre espécie e comunidades; (ii) apesar de matas secundárias possuírem uma comunidade de aves empobrecida, a forma como as aves são afetadas pela fragmentação nestes habitats é semelhante a matas primárias; (iii) efeitos de borda não são apenas análogos, mas podem ser a causa dos efeitos de área de fragmento; (iv) os efeitos de mudanças na cobertura florestal, configuração do fragmento e qualidade do habitat são altamente correlacionados e só podem ser separados com o uso de técnicas estatísticas que controlem explicitamente esta correlação; (v) a forma como o protocolo de amostragem é estruturado temporalmente afeta os padrões encontrados da relação espécie-área em paisagens fragmentadas; e por fim, (vi) métricas indicadoras, produzem resultados mais fortes e consistentes do que espécies indicadoras na identificação de áreas com alta integridade da comunidade. Assim, conclui-se que as aves de sub-bosque na Mata Atlântica são fortemente afetadas pela perda de habitat, fragmentação e mudanças na qualidade do habitat, mas esta influência é muito dependente do contexto temporal e espacial em que o estudo é realizado. Ainda, devido à baixa consistência dos resultados obtidos com amostras de curta duração, aliado ao grande poder explicativo dos modelos contendo métricas da paisagem, métricas indicadoras devem ser consideradas como a melhor estratégia para a identificação de áreas com alta integridade da comunidade. 


\section{Summary}

Tropical forests hold two thirds of all species in the world, but alterations in habitat cover, fragmentation and quality are driving tropical biodiversity to the brink of extinction. Despite the extended literature on this subject, there is a general agreement that the knowledge gained from many of these studies are context-specific and pervaded by methodological difficulties, such as high inter-correlations among many phenomena in human-altered landscapes and diverse biological responses to landscape change that depend on species traits. Because of these issues, there is great uncertainty about the generality of observed patterns and the effective application of results in the conservation of natural areas. Thus, in this thesis the aim was to bring light to some of these concerns by answering the following questions: (i) What is the role of ecosystem boundaries and edge effects on natural communities? (ii) Do bird communities show similar patterns of responses to habitat fragmentation in secondary forests as those previously reported for primary forest? (iii) Are edge and area effects on bird species functionally similar and even causally associated? (iv) How does a tropical understory bird community respond to the highly inter-correlated variation in forest cover, patch configuration and habitat quality; and is it possible to set these influences apart? (v) Could differences in sampling protocol alter community estimates or change the magnitude of ecological trends and the probability of detecting them? And (vi), which strategy is more efficient in identifying sites with the highest community integrity, indicator species or structural indicators, such as landscape metrics? To address these questions I used data from more than 7000 birds captured using mist nets in 65 sites from six landscapes with different proportions of forest cover and habitat degradation in the Atlantic Forest of Brazil. The results showed that: (i) edges are ubiquitous features of natural and human-altered landscapes and strongly influence most species; (ii) even though the bird community in secondary forests is degraded relative to primary communities, birds from these areas show similar responses to edge and area effects found for primary forests; (iii) edge effects are not only functionally similar, but might also be the main drivers of area effects in fragmented landscapes; (iv) the effects of changes in forest cover, patch configuration and habitat quality are highly confounded and without the use of analyses that explicitly model this correlation it is impossible to pull apart the relative influence of each variable; (v) the way the sampling protocol is designed temporally affects the perceived patterns of how species respond to area effects; and finally, (vi) structural indicators generate stronger and more consistent results than indicator species in predicting changes in community integrity. In conclusion, the results show that understorey birds are highly affected by changes in habitat cover, fragmentation and habitat quality in the Atlantic forest, but this influence is strongly dependent on the temporal and spatial context of the study. Also, because of the low consistency of results obtained from short-surveys, and the large explanatory power of models containing landscape metrics, structural indicators should be viewed as the best strategy for identifying sites with high community integrity. 


\section{Capítulo 1}

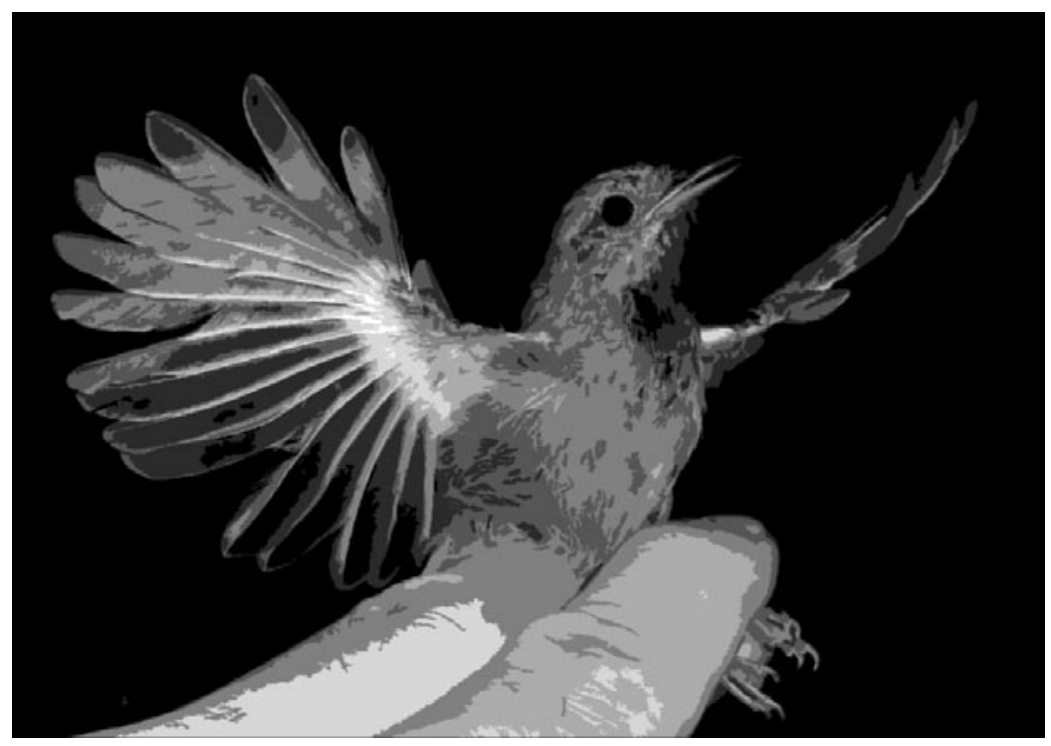




\section{1 - Introdução}

Os últimos 50 anos foram marcados por uma perda de biodiversidade sem precedentes na História e hoje se sabe que as mais importantes causas desta perda foram as mudanças nos habitats naturais (e.g. uso de solo, desmatamento), mudanças climáticas, invasão de espécies, uso excessivo dos recursos naturais (e.g. caça) e poluição (Millennium Ecosystem Assessment, 2005a). Apesar de todas estas mudanças poderem ser detectadas na maioria dos biomas, a importância de cada um destes fatores varia de bioma para bioma. Enquanto ecossistemas árticos, por exemplo, se mostram mais sensíveis a mudanças climáticas, florestas tropicais são consideravelmente mais impactadas por mudanças no uso do solo (Sala et al., 2000). Outro variante é que a magnitude da influência das atividades humanas sobre a perda de espécies também é desigual entre os diferentes biomas do planeta. Ocupando uma área de apenas 7\% do planeta, as florestas tropicais abrigam mais de 60\% de todas as espécies conhecidas, mas ao mesmo tempo, sofrem a maior perda proporcional de área (Millennium Ecosystem Assessment, 2005b; Ewers et al., 2008; Gardner et al., 2009; Bradshaw et al., 2009). Desta forma, a destruição de florestas tropicais levará a uma perda de biodiversidade incomparável a qualquer outro bioma, tornando o estudo dos efeitos das mudanças causadas pelo Homem em florestas tropicais de suma relevância (Gardner et al., 2009; Bradshaw et al., 2009).

Mas como se dão estas mudanças em habitats de florestas tropicais e porque elas são tão importantes? Em uma revisão sobre a importância e dificuldade de estudar e conservar a biodiversidade em florestas tropicais alteradas pela ação humana, Gardner et al. (2009) propõem um esquema conceitual que facilita o entendimento destas mudanças. Atividades humanas como o desmatamento, corte seletivo, agricultura e 
pecuária agem diretamente na perda e degradação do habitat, no uso do solo (e.g. tipo de matriz), na regeneração florestal e na configuração da paisagem. Tais alterações, por sua vez, afetam diretamente a disponibilidade de recursos alimentares e reprodutivos (e.g. locais para nidificação), a dispersão de indivíduos e propágulos, e o comportamento das espécies e, adicionalmente, novas condições climáticas que excedem os limites fisiológicos das espécies são criadas. Todos estes mecanismos irão então acarretar em mudanças nas populações (e.g. taxa de natalidade, mortalidade), comunidades (e.g. composição, riqueza) e interação entre espécies (e.g. cadeia trófica, mutualismo) (Gardner et al., 2009).

A criação deste esquema conceitual tão detalhado só foi possível devido à grande quantidade de informação existente sobre os efeitos das atividades humanas. Por exemplo, diversos trabalhos teóricos e empíricos mostram que a redução na quantidade de habitat altera a maioria dos padrões e processos encontrados na natureza, causando declínios ou alterações em riqueza de espécies (Giraudo et al., 2008; Klingbeil \& Willig, 2009), abundância e distribuição populacional (Lande, 1987; Hanski et al., 1996), diversidade genética (Hoehn et al., 2007), interação inter-específica (Tylianakis et al., 2008) e invasão de espécies exóticas (Didham et al., 2007). Para citar mais alguns exemplos, há também diversas evidências sobre os efeitos deletérios da degradação do habitat sobre a riqueza e composição de espécies nativas (Aleixo, 1999; Costa \& Magnusson, 2002; Barlow et al., 2006; Peters et al., 2006), comportamento das espécies (Bonte \& van Dyck, 2009) e invasão de espécies exóticas (Uehara-Prado et al., 2009). O tipo de uso do solo nas áreas não-florestadas no qual os fragmentos de habitat estão inseridos é também um fator importante, pois algumas espécies são incapazes de usar estes habitats e conseqüentemente terão maior chance de se extinguirem localmente; enquanto outras espécies, capazes de usar a matriz, serão beneficiadas (Didham et al., 
1998; Becker et al., 2007; Umetsu \& Pardini, 2007; Barlow et al., 2007a). Além disso, o tipo de matriz é também um dos determinantes na forma como as espécies serão afetadas pelo desmatamento (Antongiovanni \& Metzger, 2005; Umetsu et al., 2008; Prugh et al., 2008; Vieira et al., 2009; Fonseca et al., 2009).

Paisagens antropizadas são também altamente dinâmicas (Metzger, 2002; Teixeira et al., 2009; Metzger et al., 2009), o que significa que uma área desmatada pode vir a ser floresta novamente para ser desmatada subseqüentemente. Neste contexto, a regeneração florestal ganha especial importância, pois espécies capazes de utilizar matas secundárias estão menos sujeitas à extinção local do que aquelas que dependem exclusivamente de matas primárias ou pouco perturbadas (Laurance, 2007; Barlow et al., 2007a; Gardner et al., 2009; Bradshaw et al., 2009). Por fim, a importância da configuração e fragmentação da paisagem, que inclui questões como efeitos de borda, isolamento entre fragmentos e presença de corredores, têm sido vastamente estudadas e resultados recentes mostram que aspectos relacionados à configuração da paisagem podem ter conseqüências drásticas para a biodiversidade (Ferraz et al., 2007; Boscolo et al., 2008; Martensen et al., 2008; Awade \& Metzger, 2008; Vieira et al., 2009; Dixo et al., 2009). Como exemplo, cita-se que efeitos de borda acarretam em alterações na riqueza de espécies e composição da comunidade (Laurance, 2004; Laurance et al., 2007), tamanho populacional (Ewers \& Didham, 2007), movimentação de indivíduos (Laurance et al., 2004; Hansbauer et al., 2008), entre outros.

Apesar da extensa literatura existente, aqui citada em alguns poucos exemplos, e de haver hoje melhor compreensão sobre os efeitos das mudanças nos habitats nativos (Millennium Ecosystem Assessment, 2005b; Gardner et al., 2009), ainda há muita incerteza sobre a generalidade dos padrões encontrados, o que dificulta a definição de 
implantação de práticas conservacionistas. Gardner et al. (2009) discutem que esta dificuldade se dá porque o conhecimento atual sobre os efeitos das atividades humanas é em geral dependente do contexto em que a pesquisa foi feita e a partir disso discutem três tópicos que pesquisadores devem considerar ao estudar áreas de florestas tropicais alteradas pelo homem: (i) o conhecimento sobre valores conservacionistas é em geral gerado a partir de um número limitado de espécies; (ii) prioridades conservacionistas devem estar associadas ao conhecimento da biologia de cada espécie; e (iii) medidas imprecisas e viés do observador freqüentemente geram estimativas errôneas sobre o valor conservacionista de uma determinada área. Estas importantes considerações possuem também uma especial relevância atual, pois indicam novas lacunas de conhecimento; assim sendo, estes tópicos serão aqui apresentados em maior detalhe e usados para contextualizar as questões abordadas nesta tese.

Os resultados de pesquisas ecológicas são, de fato, geralmente bastante dependentes do contexto. Por exemplo, via de regra, espécies respondem mais fortemente à fragmentação e efeitos de borda (e.g. a interação entre dois habitats distintos) em biomas tropicais do que em zonas temperadas (Baldi, 1996; Lindell et al., 2007), e também, as espécies devem mostrar diferentes respostas à fragmentação dependendo da quantidade de cobertura vegetal na escala da paisagem (Andrén, 1994; Bascompte \& Sole, 1996; Fahrig, 2003). Este último caso tem atraído especial atenção (Arroyo-Rodríguez et al., 2009), pois há previsões de que as espécies devem responder mais fortemente ao isolamento e tamanho dos fragmentos florestais em paisagens em um contexto de baixa proporção de cobertura florestal (Fahrig, 2003). Assim, foi proposta a existência de um limiar em torno de 20 a 30\% de proporção da cobertura florestal nativa, abaixo do qual a fragmentação teria efeitos mais intensos quando comparado a paisagens mais florestadas (Fahrig, 1998; Flather \& Bevers, 2002). 
Quanto às três considerações apresentadas por Gardner et al. (2009), a primeira discute o fato que mudanças no habitat natural irão afetar cada taxon de uma maneira particular. Gardner et al. (2009) apresentam uma compilação de estudos multi-taxa em que a congruência na forma como diferentes táxons (variando de família a reino) são afetados pelas mudanças em seu habitat é em geral bastante baixa. Contudo, esta congruência não está restrita somente a táxons de ordem mais elevada. Dentro de uma mesma família, existe grande variação inter-específica na forma como as espécies se comportam em relação às mudanças no habitat (Gardner et al., 2008; Billeter et al., 2008; Bernhardt-Römermann et al., 2008), mas talvez ainda mais problemático seja o fato de que a variação intra-específica (Fahrig, 2007; Hansbauer et al., 2008; Bonte \& van Dyck, 2009) e até mesmo individual (Fleishman et al., 2002) pode ser tão grande quanto a inter-específica. O motivo pelo qual esta variação comportamental intraespecífica e individual pode ser problemática é porque a extrapolação dos resultados de pesquisas ecológicas se torna muito baixa caso o desenho experimental não seja muito bem pensado a priori. Afinal há casos em que a variação inter-anual no comportamento das espécies é grande o suficiente para gerar resultados díspares dos efeitos da fragmentação e degradação do habitat dependendo da época amostrada (Fleishman et al., 2002; Barlow et al., 2007b).

A segunda consideração apresentada por Gardner et al. (2009) está relacionada ao fato de que para se ter um completo entendimento de como as espécies são afetadas em paisagens alteradas é necessário primeiro saber o quão dependente elas são de matas primárias, ou de matas que sofreram pouco distúrbio antropogênico. A comparação da importância relativa entre matas primárias e secundárias é também um assunto bastante discutido atualmente, pois há dois pontos de vista divergentes: de um lado há autores que sugerem que com a crescente urbanização da população humana, áreas serão 
liberadas para a regeneração secundária e com isso aumentará a área de habitat nativo para as espécies, o que as "livrará" do risco de extinção (Wright \& Muller-Landau, 2006); mas por outro lado há autores que discutem que florestas secundárias possuem comunidades animais e vegetais bastante empobrecidas em relação às matas primárias, o que torna as florestas primárias insubstituíveis (Develey \& Metzger, 2006; Gardner et al., 2007; Laurance, 2007; Barlow et al., 2007a). Esta discussão também levanta a dúvida se padrões e processos observados em matas primárias seriam alterados em matas secundárias. A importância desta questão está novamente relacionada à extrapolação dos resultados. Por exemplo, segundo Gardner et al. (2009), quase 90\% dos estudos sobre efeitos da fragmentação, e áreas correlacionadas, publicados no Brasil citam trabalhos publicados pelo Projeto de Dinâmica Biológica de Fragmentos Florestais em Manaus (PDBFF), onde os fragmentos são formados por mata primária. Mas se matas primárias e secundárias funcionarem de formas diferentes, então os resultados do PDBFF poderão ser somente comparáveis a outros ambientes de áreas primárias, reduzindo assim bastante seu escopo.

A terceira e última consideração apresentada por Gardner et al. (2009) é relacionada a três principais dificuldades metodológicas presentes em praticamente todos os estudos observacionais conduzidos em áreas alteradas e que pesquisadores devem analisar durante o delineamento do projeto e análise de dados. A primeira dificuldade metodológica discutida é o fato de que a forma como as espécies são afetadas pelas mudanças nos habitats naturais é dependente da escala espacial. De fato, diferentes espécies percebem seu habitat natural de formas distintas (Cushman \& McGarigal, 2004) e a determinação da escala que mais afeta as espécies tem importância tanto durante a criação de um desenho experimental quanto na elaboração e aplicação de estratégias conservacionistas. Afinal, um experimento conduzido na escala 
errada pode não detectar padrões existentes em um determinado táxon, e da mesma forma, estratégias conservacionistas podem não ser efetivas se aplicadas numa escala imprópria. A segunda dificuldade metodológica está relacionada ao fato de que dados de ocorrência são fracos representantes de viabilidade funcional das espécies, e que é necessário haver dados coletados durante um longo período de tempo para se ter estimativas corretas dos dados populacionais. Este ponto também levanta a dúvida: quanto tempo de amostragem seria considerado suficiente e quais as conseqüências de um esforço reduzido? Apesar de esta ser uma questão bastante estudada (Mac Nally, 1997; Bergallo et al., 2003; McGlinn \& Palmer, 2009), até hoje não há solução definitiva (Elphick, 2008). A qualidade dos dados depende do esforço de coleta, que é restringido por tempo e dinheiro; e a busca pelo balanço ideal entre bons dados e dinheiro disponível é um problema do qual os pesquisadores têm de lidar (Gardner et al., 2008).

Por fim, a terceira dificuldade metodológica que praticamente todos os pesquisadores enfrentam ao estudar paisagens alteradas é que a grande maioria dos padrões e processos existentes na natureza não ocorre de forma independente dos demais (Gardner et al., 2009), no entanto poucas análises estatísticas conseguem lidar de forma eficaz com esta correlação. Há dois exemplos clássicos que sofrem destes problemas: a correlação entre perda e fragmentação de habitat (Koper et al., 2007), e a correlação entre efeitos de área do fragmento e efeitos de borda (Ewers et al., 2007). Análises estatísticas inadequadas têm sido por vezes utilizadas para responder esta questão gerando a noção de que perda de habitat é mais importante do que fragmentação (Trzcinski et al., 1999; Fahrig, 2003). De forma semelhante, efeitos de borda têm sido considerados pouco importantes e muito variáveis quando comparado aos efeitos de área (Fahrig, 2003). Porém, há uma dificuldade intrínseca de separar os efeitos de área 
de fragmento e de borda, pois ambos os efeitos são correlacionados espacialmente e atuam de forma sinergística (Laurance \& Yensen, 1991; Malcolm, 1994; Ewers et al., 2007). O melhor entendimento da relação entre os efeitos de área e borda, e de perda de habitat e fragmentação, podem auxiliar na construção de uma base teórica mais sólida para a ecologia de paisagens que ainda utiliza muito da Teoria de Biogeografia de Ilhas para explicar seus fenômenos (Laurance, 2008).

Estas são algumas das questões e dificuldades que pesquisadores enfrentam ao tentar determinar os efeitos das alterações causadas por humanos em habitats naturais. No entanto, estas dificuldades jamais deixarão de existir, enquanto que o mesmo não pode ser dito para as espécies, que estão sendo desaparecendo em uma taxa alarmante (Bradshaw et al., 2009) de até 10 milhões de espécies por década (Pimm \& Raven, 2000). Desta forma, é importante não somente determinar como a biodiversidade é alterada pelas ações humanas, mas também apontar quais seriam as melhores estratégias conservacionistas. Uma estratégia atualmente em foco é o uso de indicadores tanto para seleção quanto para monitoramento de áreas prioritárias para conservação (Mace \& Baillie, 2007). Em geral, a estratégia mais estudada é o uso de espécies indicadoras ou representativas, que são organismos cujas características (e.g. abundância, ocorrência, sucesso reprodutivo) podem ser usadas como um índice de atributos difíceis ou dispendiosos de serem medidos (Caro \& O'Doherty, 1999). Mas como discutido anteriormente, existe uma série de fatores comportamentais, temporais e espaciais que podem alterar a resposta das espécies às mudanças no habitat; de forma que alguns autores sugerem que a variação na eficácia do uso de espécies indicadoras é tão alta que esta não deve ser vista como uma estratégia confiável (Hess et al., 2006; Grenyer et al., 2006). Existem ainda outras alternativas, como o uso de variáveis ambientais como indicadores de áreas prioritárias para a conservação (Lindenmayer et al., 2002; Faith, 
2003), porém esta estratégia tem sido pouco estudada e evidências de sua eficácia são ainda bastante discutidas (Araújo, 2003).

Assim, nesta tese procurou-se buscar a resposta para algumas das questões levantadas anteriormente, uma vez que são questões relevantes do ponto de vista teórico e importantes do ponto de vista prático e conservacionista. Para esta tese, escolheu-se trabalhar na Mata Atlântica, considerado um dos "hotspots” mais ameaçados do mundo (Myers et al., 2000; Metzger, 2009). Na Mata Atlântica, mais especificamente no Planalto Atlântico de São Paulo, também podem ser encontradas condições ideais para testar a influência da perda e degradação do habitat, regeneração florestal e configuração da paisagem, uma vez que há diversas áreas com diferentes graus de fragmentação, além de florestas com diferentes graus de perturbação, porém conectadas em um bloco de aproximadamente 1 milhão de hectares (Ribeiro et al., 2009). Por fim, como grupo taxonômico escolheu-se as aves, mais especificamente as aves de subbosque. A vantagem de se estudar aves é conferida pela taxonomia do grupo bem resolvida, fácil identificação e extensa literatura disponível, o que facilita a comparação e contextualização dos resultados. Além disso, aves estão entre os grupos que melhor respondem às mudanças nos habitats naturais, de forma que o custo-benefício de estudar estes organismos é próximo ao ideal (Gardner et al., 2008)

\subsection{Objetivos}

Esta tese foi estruturada de forma que o primeiro capítulo tem o objetivo de introduzir brevemente os assuntos abordados nos capítulos 2 a 6, apresentar as áreas de estudo e métodos de coleta; enquanto que no último capítulo, os resultados encontrados são discutidos de forma integrada. Os capítulos 2 a 6 são apresentados em formato de 
manuscritos a serem publicados em revistas científicas internacionais, cujos objetivos principais encontram-se a seguir.

\subsection{1 - Capítulo 2: Bordas ecossistêmicas}

A finalidade neste capítulo foi de fazer uma revisão sobre bordas entre dois ecossistemas distintos a ser publicada na Encyclopedia of Life Sciences como um Advanced Article, cujo público-alvo é formado por estudantes de graduação e pósgraduação e pesquisadores especializados em áreas distintas. O objetivo foi de apresentar os conceitos de bordas ecossistêmicas e de efeitos de borda, além de discutir como a presença ou criação de bordas pode alterar a diversidade, condições abióticas e processos ecológicos, mediação de fluxos e interação de espécies. Apesar de bordas entre diversos tipos de ecossistemas serem discutidas neste capítulo, maior atenção é dada para bordas antropogênicas criadas entre florestas e áreas abertas. Desta forma, esta revisão é particularmente interessante para introduzir o capítulo 3.

\subsection{2 - Capítulo 3: Efeitos de borda como um dos determinantes dos efeitos de área de fragmento sobre a comunidade de aves em uma floresta secundária}

Neste capítulo existem dois objetivos principais. O primeiro objetivo é de verificar se a comunidade de aves em matas secundárias apresenta os mesmo efeitos de área de fragmento e de borda já observados para matas primárias. Pretende-se, assim, contribuir para a discussão do funcionamento e relevância de matas secundárias na conservação da biodiversidade. O segundo objetivo principal é de verificar se os efeitos de área e de borda agem de forma similar em aves e se estes estão associados de forma causal. Assim, pretende-se contribuir para um melhor entendimento da diferença teórica entre a Teoria de Biogeografia de Ilhas e Ecologia da Paisagem, e ao mesmo tempo prover 
dados que possam auxiliar na conservação de áreas fragmentadas. Para atingir este objetivo, três hipóteses são testadas: (i) A magnitude dos efeitos de borda está relacionada ao tamanho do fragmento? (ii) Efeitos de borda e tamanho de fragmento podem produzir os mesmos gradientes de alteração da composição da comunidade de aves? Se efeitos de borda forem controlados, as espécies continuam respondendo a mudanças no tamanho do fragmento? (iii) As espécies de aves mostram respostas similares a efeitos de borda e efeitos de tamanho do fragmento?

1.2.3 - Capítulo 4: Separando os efeitos correlacionados da perda de habitat, configuração e qualidade do mata na comunidade de aves em uma paisagem fragmentada

O objetivo principal foi de tentar separar e avaliar a importância relativa de três variáveis intrinsecamente correlacionadas: a perda de habitat na escala da paisagem; a configuração na escala da mancha; e a qualidade do habitat na escala local. Procurou-se, assim, contribuir para o melhor entendimento da importância relativa da perda de habitat e fragmentação e da escala espacial para comunidade de aves. Para isso foram utilizadas técnicas estatísticas que testam e modelam, ao invés de ignorar, a correlação entre as variáveis. Em particular, foi comparado o uso de partição de variância com o uso de equações estruturais para estimar a contribuição única e compartilhada entre as três escalas consideradas: paisagem, mancha, e ponto de coleta.

1.2.4 - Capítulo 5: Alterações temporais no protocolo de amostragem podem afetar a detecção de padrões ecológicos

Aqui, o objetivo principal foi de verificar se a escolha do protocolo temporal de amostragem poderia afetar os padrões ecológicos encontrados (dada a variação temporal no padrão comportamental de aves), e desta forma avaliar a consistência e poder de 
extrapolação de estudos conduzidos com esforço amostral reduzido. Para atingir este objetivo, foram analisados três diferentes itens: (i) Como a captura de aves por redes de neblina muda ao longo do dia, entre estações do ano e com o aumento de esforço amostral? (ii) Mudanças na taxa de captura podem afetar as estimativas de riqueza de espécies e composição da comunidade? (iii) Mudanças no protocolo temporal, como amostrar apenas em um período do dia, uma estação do ano e com reduzido esforço amostral, podem influenciar a detecção de padrões ecológicos?

1.2.5 - Capítulo 6: Comparando o uso de espécies e de métricas da paisagem como indicadores de mudanças na integridade da comunidade

O objetivo principal foi de comparar a eficiência do uso de espécies indicadoras ao de indicadores baseados em métricas da paisagem para detectar mudanças na composição da comunidade originadas por distúrbios humanos. Assim, pretende-se contribuir para a discussão de quais indicadores seriam mais úteis para estabelecer estratégias conservacionistas na Mata Atlântica, e em outros biomas florestais. Para atingir o objetivo principal, foram abordadas as seguintes questões: (i) Quais indicadores (espécies ou métricas da paisagem) são mais eficientes em apontar áreas com maior integridade da comunidade de aves na escala da paisagem e escala regional? (ii) Como a resolução dos dados pode afetar a eficiência destes indicadores? (iii) Qual estratégia possui maior capacidade de extrapolação, i.e. indicadores escolhidos para um local são altamente aplicáveis em outras áreas, considerando paisagens com diferentes proporções de cobertura vegetal e diferentes escalas de estudo?

\section{3 - Áreas de estudo}

Para responder as perguntas do capítulo 6 foram utilizados dados provenientes de três regiões de estudo localizadas no Planalto Atlântico de São Paulo (Fig. 1), enquanto que 
os capítulos 2 a 5 foram analisados com dados provenientes de apenas uma destas área de estudo (Tapiraí, Fig. 1c). Estas regiões foram inicialmente escolhidas para se testar questões relacionadas com o limiar de fragmentação (Fahrig, 2003), por isso as paisagens fragmentadas apresentam condições abióticas similares, mas coberturas florestais abaixo, acima e no limiar teórico de fragmentação (Metzger, 2006).

Estas três regiões possuem vegetação original classificada como floresta ombrófila densa montana (Veloso et al., 1991), hoje representada por um mosaico de estádios avançados e intermediários de sucessão, além de possuírem condições climáticas, edáficas e de relevo semelhantes. Em cada região de estudo foi realizado uma amostragem pareada de duas paisagens, uma fragmentada e outra contínua. As paisagens fragmentadas possuem área de 10.000 ha e consistem principalmente de propriedades particulares. Já as paisagens contínuas, ou controles, apresentam no mínimo 10.000 ha de cobertura florestal nativa, pois em geral estas paisagens encontram-se conectadas à Serra de Paranapiacaba, que possui aproximadamente 1 milhão de hectares e consiste no maior trecho de Mata Atlântica hoje existente (Ribeiro et al., 2009). As paisagens fragmentadas foram escolhidas por apresentarem diferentes proporções de cobertura florestal, com o objetivo então de testar a existência do limiar teórico de fragmentação (Fahrig, 1998; Flather \& Bevers, 2002). Assim foi escolhida uma paisagem abaixo do limiar (Ribeirão Grande), outra no limiar (Caucaia) e por fim uma paisagem acima do limiar de fragmentação (Tapiraí). A paisagem de Ribeirão Grande situa-se na região oeste do Planalto Atlântico, apresenta aproximadamente 10\% de cobertura florestal e tem como controle uma área florestal dentro da propriedade particular Sakamoto (Fig. 1a). A paisagem de Caucaia, por sua vez, situa-se mais ao leste, próximo à cidade de São Paulo, apresenta cerca de $30 \%$ de cobertura florestal nativa e tem como controle a Reserva Florestal do Morro Grande (Fig. 1b). Por fim, a 
paisagem de Tapiraí encontra-se entre as duas paisagens citadas acima, apresenta cerca de $50 \%$ de cobertura florestal nativa e encontra-se pareada ao Parque Estadual do Jurupará (Fig. 1b).

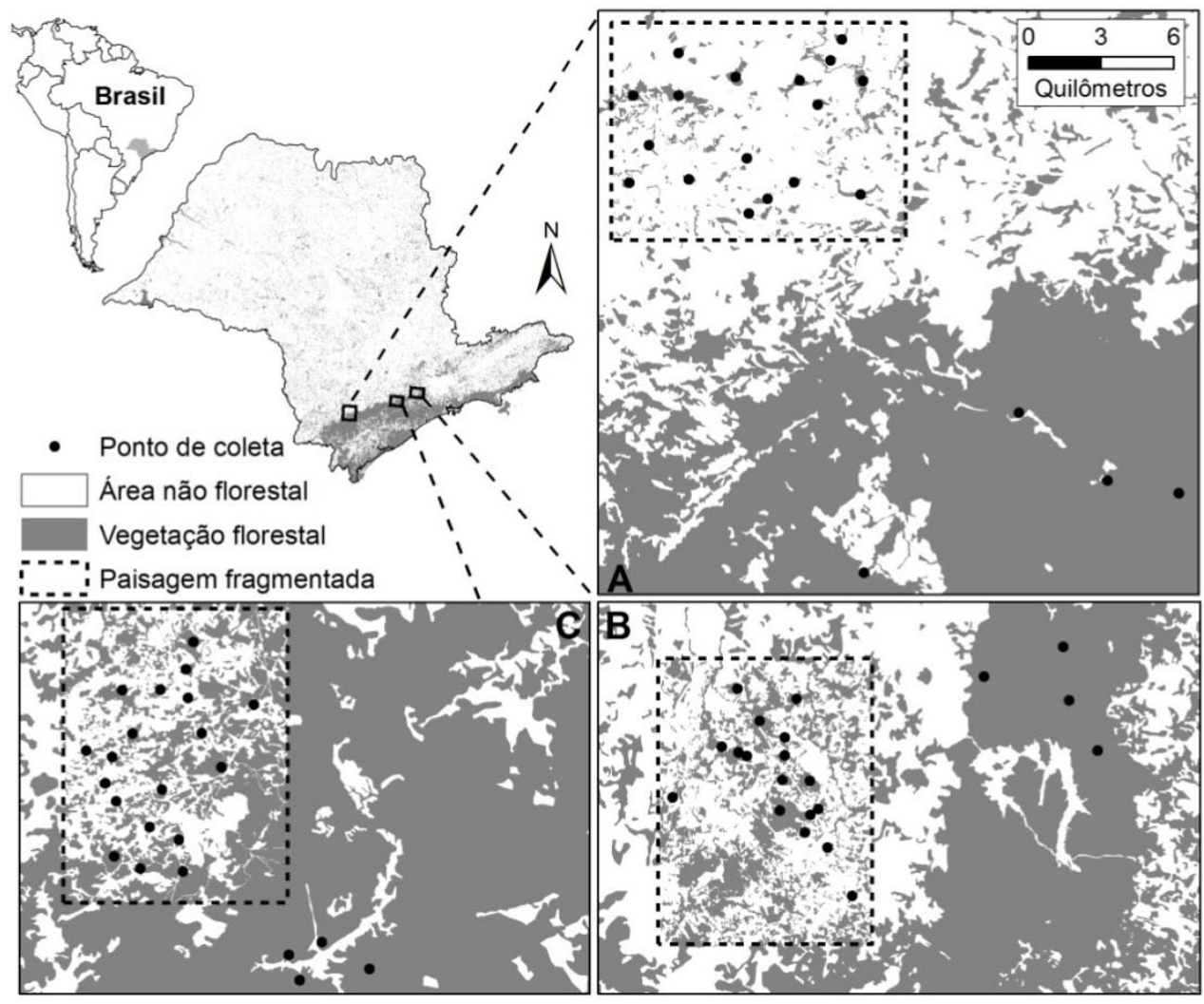

Figura 1 - Localização das áreas de estudo dentro do Estado de São Paulo. As áreas florestadas são mostradas em cinza tanto no mapa do Estado quanto nos mapas das paisagens, enquanto que os círculos pretos são os pontos de captura de aves de subbosque tanto nas paisagens fragmentadas quanto nas paisagens contínuas. Ribeirão Grande com apenas $10 \%$ de cobertura florestal encontra-se mais ao oeste do Estado (painel A). No centro, encontra-se Tapiraí com 50\% de cobertura florestal nativa (painel C) e mais ao leste do Estado encontra-se Caucaia com 30\% de cobertura florestal (painel B).

\subsection{1 - Ribeirão Grande}

A paisagem encontra-se em uma região que compreende parte dos municípios de Capão Bonito e Ribeirão Grande ( $24^{\circ} 07^{\prime}$ S, $48^{\circ} 24^{\prime}$ W). Nesta área, a altitude varia entre 800 e 1000 m acima do nível do mar, e segundo o banco de dados do Centro de Pesquisas 
Meteorológicas e Climáticas Aplicadas a Agricultura (www.cpa.unicamp.br), a temperatura média mensal varia de $18^{\circ}$ a $25^{\circ} \mathrm{C}$ e a precipitação média é de $1221 \mathrm{~mm}$ ao ano. A estação chuvosa vai de outubro a março, já que esta época do ano recebe mais de 68\% do volume hídrico. A classificação da cobertura do solo, feita com base no processamento de uma imagem Spot 5 obtida no ano de 2005, mostra que a paisagem fragmentada é composta por aproximadamente 10\% de vegetação florestal nativa, 31\% de agricultura, $42 \%$ de pastagens e 1\% de reflorestamento de árvores exóticas. Nesta paisagem foram amostrados 17 pontos localizados em fragmentos florestais, sendo que sete fragmentos eram pequenos (4 a 9 ha), oito tinham tamanho mediano (11 a 37 ha) e três eram grandes (43 a 92 ha). A paisagem contínua pareada a Ribeirão Grande encontra-se na propriedade do Sr. Sakamoto. Esta área florestal apresenta estrutura florestal típica de áreas maduras, porém nota-se impacto de corte seletivo recente (de 20 a 40 anos atrás), pois árvores de dossel de grande porte são raras. Nesta paisagem controle foram coletados dados em 4 pontos amostrais, distantes entre si por pelo menos $1,5 \mathrm{~km}$.

\subsection{2 - Caucaia}

A paisagem encontra-se em uma região que compreende parte dos municípios de Cotia e Ibiúna ( $23^{\circ} 47^{\prime}$ S, $47^{\circ} 07^{`}$ W). Nesta área, a altitude varia entre 850 e 1100 m acima do nível do mar, e segundo o banco de dados do Centro de Pesquisas Meteorológicas e Climáticas Aplicadas a Agricultura (www.cpa.unicamp.br), a temperatura média mensal varia de 16 e $23{ }^{\circ} \mathrm{C}$ e a precipitação média anual é de 1322 mm ao ano. A estação chuvosa vai de outubro a março, já que esta época do ano recebe mais de $72 \%$ do volume hídrico. A classificação da cobertura do solo, feita com base no processamento da imagem Spot 5 obtidas no ano de 2005, mostra que a paisagem fragmentada é composta por aproximadamente 30\% de vegetação florestal nativa, $8 \%$ de vegetação 
secundária (estádios iniciais de sucessão), 38\% de agricultura ou pasto, 7\% de reflorestamento e $16 \%$ de instalações rurais e urbanas. Nesta paisagem foram amostrados 17 pontos localizados em fragmentos florestais, sendo que sete fragmentos eram pequenos (2 a 9 ha), oito tinham tamanho mediano (14 a 52 ha) e três eram grandes (56 a 158 ha). A Reserva Florestal do Morro Grande tem por volta de 10.000 ha e é principalmente composta por mata secundária em estádio intermediário/avançado de sucessão, e que estão regenerando, após corte raso, há cerca de 80 anos, e por algumas manchas de florestas maduras (Metzger et al., 2006). Nesta paisagem controle foram coletados dados em 4 pontos amostrais em áreas de regeneração, distantes entre si por pelo menos $1,5 \mathrm{~km}$.

\subsection{3 - Tapiraí}

A paisagem está localizada em uma região que compreende parte dos municípios de Tapiraí e Piedade $\left(23^{\circ} 50^{\prime}\right.$ S, $\left.47^{\circ} 20^{\prime}\right)$. Nesta área, a altitude varia entre 800 e $1100 \mathrm{~m}$ acima do nível do mar, e segundo o banco de dados do Centro de Pesquisas Meteorológicas e Climáticas Aplicadas a Agricultura (www.cpa.unicamp.br), a temperatura média mensal varia de $15^{\circ}$ a $22^{\circ} \mathrm{C}$ e a precipitação média é de $1808 \mathrm{~mm}$ ao ano. A estação chuvosa vai de outubro a março, já que esta época do ano recebe mais de 68\% do volume hídrico. A classificação da cobertura do solo feita com base no processamento da imagem Spot 5 obtida no ano de 2005, mostra que a paisagem fragmentada é composta por aproximadamente 50\% de vegetação florestal nativa, 3\% de vegetação secundária em estádios iniciais de sucessão, 30\% de agricultura ou pasto e 5\% de reflorestamento de eucalipto. Nesta paisagem foram amostrados 19 pontos localizados em fragmentos florestais, sendo que sete fragmentos eram pequenos (2 a 5 ha), oito tinham tamanho mediano (18 a 41 ha) e três eram grandes (78 a 156 ha). 
Foram também amostrados 8 pontos na borda de fragmentos, sendo que 4 pontos amostrais estavam localizados em fragmentos de tamanho mediano e os demais em fragmentos de tamanho grande. O Parque Estadual de Jurupará, adjacente à paisagem fragmentada de Tapiraí, tem por volta de 26.000 ha e é principalmente composto por mata secundária em estádio avançado de sucessão, sem sinais recentes de perturbação (indicado pela presença de diversas árvores com diâmetro à altura do peito $>1 \mathrm{~m}$ ), e estrutura e composição similar a encontrada em florestas primárias (Develey \& Metzger, 2006). Nesta paisagem controle foram coletados dados em 4 pontos amostrais, distantes entre si por pelo menos $1,5 \mathrm{~km}$.

\section{4 - Método de amostragem de aves de sub-bosque}

Para a amostragem de aves, escolheu-se o método de redes de neblina. Apesar de este método ser alvo de diversas críticas (Remsen \& Good, 1996), sua escolha teve como principal objetivo reduzir o viés do observador e manter a homogeneidade na qualidade dos dados (Karr, 1981; Pearman, 2002), uma vez que para coletar dados dos 65 pontos amostrais foram necessário 6 anos de coleta (de 2001 a 2007) e a supervisão de

diferentes pesquisadores. Alexandre C. Martensen supervisionou a amostragem das paisagens de Caucaia e Ribeirão Grande, e seus respectivos controles, enquanto Tapiraí e Jurupará foram por mim supervisionadas.

Em cada ponto amostral foram utilizadas 10 redes de neblina (12 $\mathrm{m}$ de comprimento, $2.5 \mathrm{~m}$ de altura, $31 \mathrm{~mm}$ de malha) dispostas em uma linha reta, e sempre que possível seguindo o nível de relevo. Cada local foi amostrado duas vezes na estação seca e duas vezes na estação chuvosa para controlar possíveis diferenças sazonais na movimentação de aves, sendo que em média cada um dos 65 pontos amostrais foi amostrado por 637 horas/rede por local (Desv. Pad = 76.7). As redes eram checadas a cada hora e fechadas sempre que havia chuva. As aves capturadas eram identificadas, 
pesadas, medidas e marcadas individualmente com anilhas cedidas pelo Centro Nacional de Pesquisa para a Conservação de Aves Silvestres - CEMAVE (registro junto ao CEMAVE: 522117) e liberadas próximo às redes.

Houve, no entanto, pequenas mudanças no protocolo e esforço amostral entre as paisagens amostradas. Nas paisagens de Caucaia e Morro Grande, que foram as primeiras a serem amostradas, as redes eram abertas com o nascer do sol e fechadas nove horas depois durante 8 dias não-consecutivos. Nestas paisagens, cada sítio foi amostrado em média por 537 horas-rede. Na paisagem de Ribeirão Grande e Sakamoto, as redes eram abertas em quatro rodadas de dois dias consecutivos. No primeiro dia as redes eram abertas com o nascer do sol e fechadas ao pôr-do-sol, enquanto no segundo dia a redes eram novamente abertas no nascer do sol e fechadas seis horas depois. Nestas paisagens, o esforço médio por fragmento foi de 691 horas-rede. Já em Tapiraí e Jurupará, as últimas paisagens a serem amostradas, o protocolo foi o mesmo utilizado na paisagem de Ribeirão Grande e Sakamoto, porém na ultima rodada as redes foram fechadas quando completaram-se 680 horas-rede por local, de forma que todas os pontos amostrais tiveram exatamente o mesmo esforço amostral. Apesar de haver diferenças no esforço amostral entre paisagens, análises dos dados (Capítulo 5) mostram que com apenas 340 horas/rede seriam obtidos os mesmo resultados e padrões ecológicos que foram obtidos com 680 horas/rede, de forma que não há razão para esperar que estas diferenças resultem em estimativas incorretas da comunidade de aves. 


\section{Bibliografia}

Aleixo, A. (1999) Effects of selective logging on a bird community in the Brazilian Atlantic forest. Condor, 101, 537-548.

Andrén, H. (1994) Effects of habitat fragmentation on birds and mammals in landscapes with different proportions of suitable habitat: a review. Oikos, 71, 355-366.

Antongiovanni, M. \& Metzger, J. P. (2005) Influence of matrix habitats on the occurrence of insectivorous bird species in Amazonian forest fragments. Biological Conservation, 122, 441-451.

Araújo, M. B. (2003) Predicting species diversity with ED: the quest for evidence. Ecography, 26, 380-383.

Arroyo-Rodríguez, V., Pineda, E., Escobar, F., \& Benitez-Malvido, J. (2009) Value of small patches in the conservation of plant-species diversity in highly fragmented rainforest. Conservation Biology in press

Awade, M. \& Metzger, J. P. (2008) Using gap-crossing capacity to evaluate functional connectivity of two Atlantic rainforest birds and their response to fragmentation. Austral Ecology, 33, 863-871.

Baldi, A. (1996) Edge effects in tropical versus temperate forest bird communities: three alternative hypotheses for the explanation of differences. Acta Zoologica Academiae Scientiarum Hungaricae, 42, 163-172.

Barlow, J., Gardner, T. A., Araujo, I. S., Avila-Pires, T. C., Bonaldo, A. B., Costa, J. E., Esposito, M. C., Ferreira, L. V., Hawes, J., Hernandez, M. I. M., Hoogmoed, M. S., Leite, R. N., Lo-Man-Hung, N. F., Malcolm, J. R., Martins, M. B., Mestre, L. A. M., Miranda-Santos, R., Nunes-Gutjahr, A. L., Overal, W. L., Parry, L., Peters, S. L., Ribeiro-Junior, M. A., da Silva, M. N. F., Silva Motta, C., \& Peres, C. A. (2007a) Quantifying the biodiversity value of tropical primary, secondary, and plantation forests. Proceedings of the National Academy of Sciences, 104, 18555-18560.

Barlow, J., Overal, W. L., Araujo, I. S., Gardner, T. A., \& Peres, C. A. (2007b) The value of primary, secondary and plantation forests for fruit-feeding butterflies in the Brazilian Amazon. Journal of Applied Ecology, 44, 1001-1012.

Barlow, J., Peres, C. A., Henriques, L. M. P., Stouffer, P. C., \& Wunderle, J. M. (2006) The responses of understorey birds to forest fragmentation, logging and wildfires: an Amazonian synthesis. Biological Conservation, 128, 182-192.

Bascompte, J. \& Sole, R. V. (1996) Habitat fragmentation and extinction thresholds in spatially explicit models. Journal of Animal Ecology, 65, 465-473.

Becker, C. G., Fonseca, C. R., Haddad, C. F. B., Batista, R. F., \& Prado, P. I. (2007) Habitat split and the global decline of amphibians. Science, 318, 1775-1777. 
Bergallo, H. G., Esbérard, C. E. L., Mello, M. A. R., Lins, V., Mangolin, R., Mello, G. G. S., \& Baptista, M. (2003) Bat Species Richness in Atlantic Forest: What Is the Minimum Sampling Effort? Biotropica, 35, 278-287.

Bernhardt-Römermann, M., Römermann, C., Nuske, R., Parth, A., Klotz, S., Schmidt, W., \& Stadler, J. (2008) On the identification of the most suitable traits for plant functional trait analyses. Oikos, 117, 1533-1541.

Billeter, R., Liira, J., Bailey, D., Bugter, R., Arens, P., Augenstein, I., Aviron, S., Baudry, J., Bukacek, R., Burel, F., Cerny, M., De Blust, G., De Cock, R., Diekotter, T., Dietz, H., Dirksen, J., Dormann, C., Durka, W., Frenzel, M., Hamersky, R., Hendrickx, F., Herzog, F., Klotz, S., Koolstra, B., Lausch, A., Le Coeur, D., Maelfait, J. P., Opdam, P., Roubalova, M., Schermann, A., Schermann, N., Schmidt, T., Schweiger, O., Smulders, M. J. M., Speelmans, M., Simova, P., Verboom, J., van Wingerden, W. K. R. E., \& Zobel, M. (2008) Indicators for biodiversity in agricultural landscapes: a pan-European study. Journal of Applied Ecology, 45, 141150.

Bonte, D. \& van Dyck, H. (2009) Mate-locating behaviour, habitat-use, and flight morphology relative to rainforest disturbance in an Afrotropical butterfly. Biological Journal of the Linnean Society, 96, 830-839.

Boscolo, D., Candia-Gallardo, C., Awade, M., \& Metzger, J. P. (2008) Importance of Interhabitat Gaps and Stepping-Stones for Lesser Woodcreepers (Xiphorhynchus fuscus) in the Atlantic Forest, Brazil. Biotropica, 40, 273-276.

Bradshaw, C. J. A., Sodhi, N. S., \& Brook, B. W. (2009) Tropical turmoil: a biodiversity tragedy in progress. Frontiers in Ecology and the Environment, 7, 79-87.

Caro, T. M. \& O'Doherty, G. (1999) On the use of surrogate species in conservation biology. Conservation Biology, 13, 805-814.

Costa, F. R. C. \& Magnusson, W. (2002) Selective logging effects on abundance, diversity, and composition of tropical understory herbs. Ecological Applications, 12, 807-819.

Cushman, S. \& McGarigal, K. (2004) Hierarchical analysis of forest bird speciesenvironment relationships in the Oregon coast range. Ecological Applications, 14, 1090-1105.

Develey, P. F. \& Metzger, J. P. (2006) Emerging threats to birds in Brazilian Atlantic forests: the roles of forest loss and configuration in a severely fragmented ecosystem. Emerging Threats to Tropical Forests (ed. by W. F. Laurance and C. A. Peres), pp. 269-290. University of Chicago Press, London.

Didham, R. K., Hammond, P. M., Lawton, J. H., Eggleton, P., \& Stork, N. E. (1998) Beetle species responses to tropical forest fragmentation. Ecological Monographs, 68, 295-323.

Didham, R. K., Tylianakis, J. M., Gemmell, N. J., Rand, T. A., \& Ewers, R. M. (2007) Interactive effects of habitat loss and species invasion on native species decline. Trends in Ecology \& Evolution, 22, 489-496. 
Dixo, M., Metzger, J. P., Morgante, J. S., \& Zamudio, K. R. (2009) Habitat fragmentation reduces genetic diversity and connectivity among toad populations in the Brazilian Atlantic Coastal Forest. Biological Conservation in press.

Elphick, C. S. (2008) How you count counts: the importance of methods research in applied ecology. Journal of Applied Ecology, 45, 1313-1320.

Ewers, R. M. \& Didham, R. K. (2007) The effect of fragment shape and species' sensitivity to habitat edges on animal population size. Conservation Biology, 21, 926-936.

Ewers, R. M., Laurance, W. F., \& Souza, C. M. (2008) Temporal fluctuations in Amazonian deforestation rates. Environmental Conservation, 35, 303-310.

Ewers, R. M., Thorpe, S., \& Didham, R. K. (2007) Synergistic interactions between edge and area effects in a heavily fragmented landscape. Ecology, 88, 96-106.

Fahrig, L. (1998) When does fragmentation of breeding habitat affect population survival? Ecological Modelling, 105, 273-292.

Fahrig, L. (2003) Effects of habitat fragmentation on biodiversity. Annual Review of Ecology, Evolution and Systematics, 34, 487-515.

Fahrig, L. (2007) Non-optimal animal movement in human-altered landscapes. Functional Ecology, 21, 1003-1015.

Faith, D. P. (2003) Environmental diversity (ED) as surrogate information for specieslevel biodiversity. Ecography, 26, 374-379.

Ferraz, G., Nichols, J. D., Hines, J. E., Stouffer, P. C., Bierregaard, R. O., Jr., \& Lovejoy, T. E. (2007) A large-scale deforestation experiment: effects of patch area and isolation on Amazon birds. Science, 315, 238-241.

Flather, C. H. \& Bevers, M. (2002) Patchy reaction-diffusion and population abundance: The relative importance of habitat amount and arrangement. American Naturalist, 159, 40-56.

Fleishman, E., Ray, C., Sjogren-Gulve, P., Boggs, C. L., \& Murphy, D. D. (2002) Assessing the roles of patch quality, area, and isolation in predicting metapopulation dynamics. Conservation Biology, 16, 706-716.

Fonseca, C. R., Ganade, G., Baldissera, R., Becker, C. G., Boelter, C. R., Brescovit, A. D., Campos, L. M., Fleck, T., Fonseca, V. S., Hartz, S. M., Joner, F., Käffer, M. I., Leal-Zanchet, A. M., Marcelli, M. P., Mesquita, A. S., Mondin, C. A., Paz, C. P., Petry, M. V., Piovensan, F. N., Putzke, J., Stranz, A., Vergara, M., \& Vieira, E. M. (2009) Towards an ecologically-sustainable forestry in the Atlantic Forest. Biological Conservation, 142, 1209-1219.

Gardner, T. A., Barlow, J., Chazdon, R. L., Ewers, R. M., Harvey, C. A., Peres, C. A., \& Sodhi, N. S. (2009) Prospects for tropical forest biodiversity in a human-modified world. Ecology Letters in press. 
Gardner, T. A., Barlow, J., Parry, L. W., \& Peres, C. A. (2007) Predicting the uncertain future of tropical forest species in a data vacuum. Biotropica, 39, 25-30.

Gardner, T. A., Barlow, J., Araujo, I. S., Avila-Pires, T. C., Bonaldo, A. B., Costa, J. E., Esposito, M. C., Ferreira, L. V., Hawes, J., Hernandez, M. I. M., Hoogmoed, M. S., Leite, R. N., Lo-Man-Hung, N. F., Malcolm, J. R., Martins, M. B., Mestre, L. A. M., Miranda-Santos, R., Overal, W. L., Parry, L., Peters, S. L., Ribeiro-Junior, M. A., da Silva, M. N. F., Silva Motta, C., \& Peres, C. A. (2008) The cost-effectiveness of biodiversity surveys in tropical forests. Ecology Letters, 11, 139-150.

Giraudo, A., Matteucci, S., Alonso, J., Herrera, J., \& Abramson, R. (2008) Comparing bird assemblages in large and small fragments of the Atlantic Forest hotspots. Biodiversity and Conservation, 17, 1251-1265.

Grenyer, R., Orme, C. D., Jackson, S. F., Thomas, G. H., Davies, R. G., Davies, T. J., Jones, K. E., Olson, V. A., Ridgely, R. S., Rasmussen, P. C., Ding, T. S., Bennett, P. M., Blackburn, T. M., Gaston, K. J., Gittleman, J. L., \& Owens, I. P. F. (2006) Global distribution and conservation of rare and threatened vertebrates. Nature, 444, 93-96.

Hansbauer, M. M., Storch, I., Leu, S., Nieto-Holguin, J. P., Pimentel, R. G., Knauer, F., \& Metzger, J. P. (2008) Movements of neotropical understory passerines affected by anthropogenic forest edges in the Brazilian Atlantic rainforest. Biological Conservation, 141, 782-791.

Hanski, I., Moilanen, A., \& Gyllenberg, M. (1996) Minimum viable metapopulation size. American Naturalist, 147, 527-541.

Hess, G. R., Bartel, R. A., Leidner, A. K., Rosenfeld, K. M., Rubino, M. J., Snider, S. B., \& Ricketts, T. H. (2006) Effectiveness of biodiversity indicators varies with extent, grain, and region. Biological Conservation, 132, 448-457.

Hoehn, M., Sarre, S. D., \& Henle, K. (2007) The tales of two geckos: does dispersal prevent extinction in recently fragmented populations? Molecular Ecology, 16, 32993312.

Karr, J. R. (1981) Surveying birds with mist nets. Studies in Avian Biology, 6, 62-67.

Klingbeil, B. T. \& Willig, M. R. (2009) Guild-specific responses of bats to landscape composition and configuration in fragmented Amazonian rainforest. Journal of Applied Ecology in press.

Koper, N., Schmiegelow, F., \& Merrill, E. (2007) Residuals cannot distinguish between ecological effects of habitat amount and fragmentation: implications for the debate. Landscape Ecology, 22, 811-820.

Lande, R. (1987) Extinction thresholds in demographic models of territorial populations. The American Naturalist, 130, 624.

Laurance, S. G. W. (2004) Responses of understory rain forest birds to road edges in Central Amazonia. Ecological Applications, 14, 1344-1357. 
Laurance, S. G. W., Stouffer, P. C., \& Laurance, W. E. (2004) Effects of road clearings on movement patterns of understory rainforest birds in central Amazonia. Conservation Biology, 18, 1099-1109.

Laurance, W. F. (2008) Theory meets reality: how habitat fragmentation research has transcended island biogeographic theory. Biological Conservation, 141, 1731-1744.

Laurance, W. F. \& Yensen, E. (1991) Predicting the impacts of edge effects in fragmented habitats. Biological Conservation, 55, 77-92.

Laurance, W. F. (2007) Have we overstated the tropical biodiversity crisis? Trends in Ecology \& Evolution, 22, 65-70.

Laurance, W. F., Nascimento, H. E. A. M., Laurance, S. G. W., Andrade, A., Ewers, R. M., Harms, K. E., Luizao, R. C., \& Ribeiro, J. E. L. S. (2007) Habitat fragmentation, variable edge effects, and the landscape-divergence hypothesis. PLoS ONE, 2, e1017.

Lindell, C. A., Riffell, S. K., Kaiser, S. A., Battin, A. L., Smith, M. L., \& Sisk, T. D. (2007) Edge responses of tropical and temperate birds. Wilson Journal of Ornithology, 119, 205-220.

Lindenmayer, D. B., Cunningham, R. B., Donnelly, C. F., \& Lesslie, R. (2002) On the use of landscape surrogates as ecological indicators in fragmented forests. Forest Ecology and Management, 159, 203-216.

Mac Nally, R. (1997) Monitoring forest bird communities for impact assessment: the influence of sampling intensity and spatial scale. Biological Conservation, 82, 355367.

Mace, G. M. \& Baillie, J. E. M. (2007) The 2010 biodiversity indicators: Challenges for science and policy. Conservation Biology, 21, 1406-1413.

Malcolm, J. R. (1994) Edge effects in Central Amazonian forest fragments. Ecology, 75, 2438-2445.

Martensen, A. C., Pimentel, R. G., \& Metzger, J. P. (2008) Relative effects of fragment size and connectivity on bird community in the Atlantic Rain Forest: Implications for conservation. Biological Conservation, 141, 2184-2192.

McGlinn, D. J. \& Palmer, M. W. (2009) Modeling the sampling effect in the species-time-area relationship. Ecology, 90, 836-846.

Metzger, J. P. (2002) Landscape dynamics and equilibrium in areas of slash-and-burn agriculture with short and long fallow period (Bragantina region, NE Brazilian Amazon). Landscape Ecology, 17, 419-431.

Metzger, J. P. (2006) Conservação da Biodiversidade em Paisagens Fragmentadas no Planalto Atlântico de São Paulo - II. Projeto de Pesquisa, CNPq, Brasília.

Metzger, J. P., Alves, L. F., Pardini, R., Dixo, M., Nogueira, A. A., Negrão, M. F. F., Martensen, A. C., \& Catharino, E. L. M. (2006) Características ecológicas e 
implicações para a conservação da Reserva Florestal do Morro Grande. Biota Neotropica, 6.

Metzger, J. P. (2009) Conservation issues in the Brazilian Atlantic forest. Biological Conservation, 142, 1138-1140.

Metzger, J. P., Martensen, A. C., Dixo, M., Bernacci, L. C., Ribeiro, M. C., Teixeira, A. M. G., \& Pardini, R. (2009) Time-lag in biological responses to landscape changes in a highly dynamic Atlantic forest region. Biological Conservation, 142, 1166-1177.

Millennium Ecosystem Assessment (2005a) Ecosystems and Human Well-being: biodiversity synthesis. World Resources Institute, Washington, DC.

Millennium Ecosystem Assessment (2005b) Ecosystems and Human Well-Being: Synthesis. Island Press, Washington, DC.

Myers, N., Mittermeier, C. G., Mittermeier, R. A., Fonseca, G. A. B., \& Kent, J. (2000) Biodiversity hotspots for conservation priorities. Nature, 403, 853-858.

Pearman, P. B. (2002) The scale of community structure: Habitat variation and avian guilds in tropical forest understory. Ecological Monographs, 72, 19-39.

Peters, S. L., Malcolm, J. R., \& Zimmerman, B. L. (2006) Effects of selective logging on bat communities in the southeastern Amazon. Conservation Biology, 20, 14101421.

Pimm, S. L. \& Raven, P. (2000) Extinction by numbers. Nature, 403, 843-845.

Prugh, L. R., Hodges, K. E., Sinclair, A. R. E., \& Brashares, J. S. (2008) Effect of habitat area and isolation on fragmented animal populations. Proceedings of the National Academy of Sciences, 105, 20770-20775.

Remsen, J. V. \& Good, D. A. (1996) Misuse of data from mist-net captures to assess relative abundance in bird populations. Auk, 113, 381-398.

Ribeiro, M. C., Metzger, J. P., Martensen, A. C., Ponzoni, F. J., \& Hirota, M. M. (2009) The Brazilian Atlantic Forest: How much is left, and how is the remaining forest distributed? Implications for conservation. Biological Conservation, 142, 1141-1153.

Sala, O. E., Chapin, F. S., III, Armesto, J. J., Berlow, E., Bloomfield, J., Dirzo, R., Huber-Sanwald, E., Huenneke, L. F., Jackson, R. B., Kinzig, A., Leemans, R., Lodge, D. M., Mooney, H. A., Oesterheld, M., Poff, N. L., Sykes, M. T., Walker, B. H., Walker, M., \& Wall, D. H. (2000) Global biodiversity scenarios for the year 2100. Science, 287, 1770-1774.

Teixeira, A. M., Soares-Filho, B. S., Freitas, S. R., \& Metzger, J. P. (2009) Modeling landscape dynamics in an Atlantic Rainforest region: Implications for conservation. Forest Ecology and Management, 257, 1219-1230.

Trzcinski, M. K., Fahrig, L., \& Merriam, G. (1999) Independent effects of forest cover and fragmentation on the distribution of forest breeding birds. Ecological Applications, 9, 586-593. 
Tylianakis, J. M., Didham, R. K., Bascompte, J., \& Wardle, D. A. (2008) Global change and species interactions in terrestrial ecosystems. Ecology Letters, 11, 1351-1363.

Uehara-Prado, M., Fernandes, J. d. O., Bello, A. d. M., Machado, G., Santos, A. J., Vazde-Mello, F. Z., \& Freitas, A. V. L. (2009) Selecting terrestrial arthropods as indicators of small-scale disturbance: A first approach in the Brazilian Atlantic Forest. Biological Conservation, 142, 1220-1228.

Umetsu, F., Metzger, J. P., \& Pardini, R. (2008) Importance of estimating matrix quality for modeling species distribution in complex tropical landscapes: a test with Atlantic forest small mammals. Ecography, 31, 359-370.

Umetsu, F. \& Pardini, R. (2007) Small mammals in a mosaic of forest remnants and anthropogenic habitats-evaluating matrix quality in an Atlantic forest landscape. Landscape Ecology, 22, 517-530.

Veloso, H. P., Rangel-Filho, A. L. R., \& Lima, J. C. A. (1991) Classificação da vegetação brasileira adaptada a um sistema universal. IBGE, Rio de Janeiro, Brasil..

Vieira, M. V., Olifiers, N., Delciellos, A. C., Antunes, V. Z., Bernardo, L. R., Grelle, C. E. V., \& Cerqueira, R. (2009) Land use vs. fragment size and isolation as determinants of small mammal composition and richness in Atlantic Forest remnants. Biological Conservation, 142, 1191-1200.

Wright, S. J. \& Muller-Landau, H. C. (2006) The future of tropical forest species. Biotropica, 38, 287-301. 


\section{Capítulo 2}

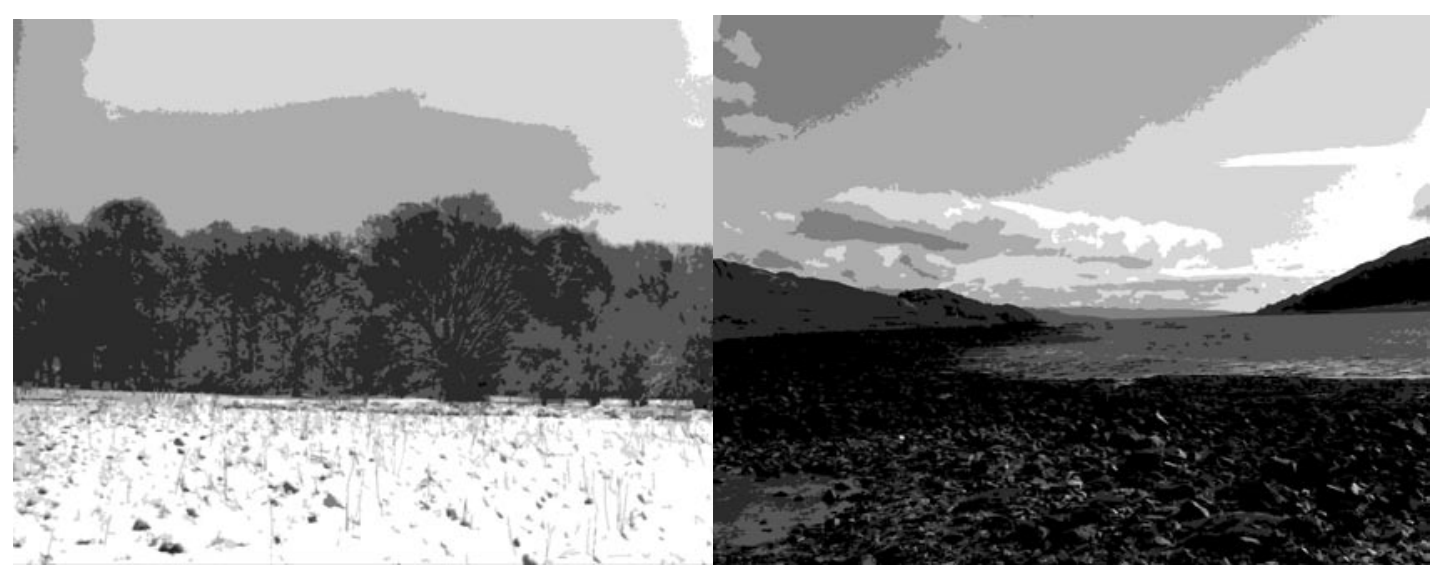




\section{Capítulo 2}

\section{Ecosystem Boundaries}

Cristina BANKS-LEITE \& Robert M. EWERS

A ser publicado na Encyclopedia of Life Sciences como um Advanced Article. 


\section{Resumo}

Bordas ecossistêmicas são zonas de transição entre dois habitats adjacentes. Bordas podem ser encontradas naturalmente em todos os biomas, mas sua ocorrência tem aumentado consideravelmente devido às mudanças nos habitats naturais causadas pela ação humana. Ambientes de borda produzem alterações bióticas e abióticas na medida em que estes ambientes modificam as condições microclimáticas, a composição de comunidade animais e vegetais e interações entre espécies. Os fluxos de energia, material e organismos entre ambientes separados por bordas são também fortemente alterados, sendo que a taxa destes fluxos é mediada por uma série de variáveis. 


\title{
Ecosystem Boundaries
}

\begin{abstract}
Ecosystem boundaries are zones of transitions between two adjacent habitats. They occur naturally in all biomes but the extent of boundaries has been greatly increased by anthropogenic habitat modification. Habitat edges have profound effects on abiotic and biotic environments, altering microclimate, the composition of plant and animal communities and the strength of species interactions. The rate of flows of energy, material and organisms across habitat edges is altered, with the size of these fluxes mediated by a wide range of variables.
\end{abstract}

Key-words: ecotone, edge effect, edge species, habitat fragmentation

\section{Key concepts:}

- Ecosystem boundaries are the locations exhibiting gradients of change in environmental conditions and a related shift in the composition of plant and/or animal communities

- Edge effect is the influence that one ecosystem exerts on an adjacent ecosystem

- The creation of habitat edges generates a new combination of environmental conditions by changing the amount of sunlight, wind, temperature and humidity

- Habitat edges often support high species diversity, but the combination of species present at edges is very different to the one found deep inside continuous habitats

- Neighbouring ecosystems experience flows of organisms, materials and energy across the shared boundary 


\section{Content list:}

- Introduction

- Diversity in habitat edges

- Abiotic changes and their effects on ecological processes at edges

- Mediation of cross-system flows

- Species interactions

- Conclusion

\section{1 - Introduction}

\section{Defining an ecosystem boundary}

Ecosystems are the combination of the environment, plant and animal communities in a particular habitat or region. While some species are able to endure remarkably diverse conditions and, as a result, be present throughout widespread regions of the globe, most species are dependent on the environmental conditions specific to their home ecosystem. Thus, whenever environmental gradients occur (e.g. climatic, edaphic, altitudinal), there is often a related shift in the composition of plant and animal communities, It is locations exhibiting these gradients of change that are considered to be ecosystem boundaries. (See also: Ecosystem Concepts: Introduction)

It is often difficult to clearly delineate ecosystem boundaries in nature, because a boundary for one species or ecological characteristic is often not a boundary for another. Moreover, ecosystem boundaries are more correctly considered as a transition zone from one ecosystem to the next, as opposed to a distinct line, making the job of defining 
an ecosystem boundary a complex one. For example, even at an apparently sharp and well-defined boundary such as a field abutting a forest, the width of the boundary zone differs depending on the species or ecological characteristic being studied, with some characteristics such as temperature changing over a narrow transition zone (Cadenasso et al., 1997), but others such as the abundance of species changing over a very wide transition zone (Ewers \& Didham, 2008).

Types of ecosystem boundaries: from natural to anthropogenic

Ecosystem boundaries can take many forms depending on how they were created, but the two main types of ecosystem boundaries are those caused by an environmental change or by an anthropogenic modification to natural habitats. For instance, in a tropical forest, natural ecosystem boundaries can occur between evergreen and riparian forest, and between the riparian forest and the river that it borders (Fig. 1a). Near the shore in coastal regions, ecosystem boundaries occur across the gradient from marine to intertidal to foreshore environments (Fig. 1b). As habitats are converted from natural to human land uses, anthropogenic boundaries have been created in almost all natural ecosystems. Common examples of anthropogenic boundaries are those between natural grasslands and croplands, croplands and forests (natural or plantations), or plantations of exotic trees and natural forests (Fig. 1c,d). In the past few decades, anthropogenic ecosystem boundaries have become one of the most comprehensively researched areas in ecology due to a steadily increasing awareness of their ecological effects (Ries et al., 2004).

$<$ Figure 1 near here $>$ 
Edge effects in ecology and conservation biology

The ecological conditions in one habitat often penetrate across an ecosystem boundary to influence the conditions of a neighbouring habitat. This influence of one ecosystem on an adjacent ecosystem is known as an edge effect (Murcia, 1995). For example, the microclimatic conditions inside an evergreen rainforest are fairly stable; humidity is high, light levels and temperature are low. At anthropogenic forest edges, however, trees that were previously embedded inside the forest can now be adjacent to a more open ecosystem such as a pasture. These trees experience much hotter, drier and lighter conditions with greater amounts of diurnal variation, as the microclimatic conditions of the pasture ecosystem penetrate the forest ecosystem. Moreover, the pasture microclimate near the forest will also be slightly more humid, colder and darker than pasture sites far from the forest (Cadenasso et al., 1997).

The width of the transition zone where edge effects can be detected is not fixed; it varies greatly depending on the taxa or ecological characteristic that is being assessed (Ewers \& Didham, 2006b). Microclimatic effects tend to stabilise within $50 \mathrm{~m}$ of a habitat edge (Cadenasso et al., 1997), whereas there is now direct evidence showing that edge effects on invertebrates can extend over more than one kilometre (Ewers \& Didham, 2008). But edge effects are not fixed throughout the transition zone, and are better viewed as a continuum from strong to weak effects as one moves from the boundary to the interior of the two habitats that form the boundary. Edge effects vary in two distinct components: magnitude or amplitude and the scale or the spatial extent over which the effect occur (Ewers \& Didham, 2006b). The magnitude of an edge effect is the difference between the maximum and minimum values of any given ecological characteristic that is measured across the transition zone from the interior of one habitat to the interior of the other; while the extent of an edge effect is the distance over which 
the changes in the response variable can be detected. Although most authors recognize that edge effects impact the ecosystems on both sides of the boundary, few studies actually record ecological characteristics in both ecosystems. Rather, they tend to focus their research effort on one of the two ecosystems forming the boundary (Fonseca \& Joner, 2007). However, without collecting information from both sides of the ecosystem boundary it is difficult to quantify the magnitude and extent of edge effect. Furthermore, by measuring both sides of the boundary, edge effects can then be modelled using non-linear regression techniques. Modern methods for defining the location of ecosystem boundaries now typically use algebraic derivatives to assess changes of an ecological characteristic across a suspected transition zone (Walker et al., 2003; Ewers \& Didham, 2006b).

Besides being highly variable in space, edge effects are also not constant through time. There is a time lag between the creation of edges and the manifestation of their effects, and in some cases this time lag can take more than 20 years to manifest itself (Laurance, 2008). Although some animals might instantly start avoiding a newly created edge, most plants will take many years to respond to this new environment and even longer periods will be needed before these effects are transmitted through a trophic chain. But time since creation of edges is not the only source of temporal variability; edge effects can also vary through the day, between seasons and between years (Murcia, 1995). Temporal effects are usually viewed as random or confounding effects, but understanding the reasons of their influence might shed light into the own causes of edge effects. In Madagascar, for instance, some frog species actively avoided habitat edges in the dry season but showed no such aversion during the wet season, showing that changes in microclimatic conditions were the main reason why these species were so influenced by edge effects (Lehtinen et al., 2003). 
Edge effects have gained particular recognition in the field of landscape ecology and in the study of habitat fragmentation (Laurance, 2008). Habitat fragments experience the effects of edges along their entire perimeter and are strongly affected by the matrix habitat that surrounds them. The total impact of edge effects in habitat fragments is a function of the fragment's edge:area ratio, with smaller patches having a larger proportion of their area encompassed within the transition zone and consequently impacted by the matrix habitat. Edge effects can penetrate hundreds of meters inside a habitat fragment (See: Cross-system flows), so small fragments may not contain habitat that is unaffected by the habitat boundary. To determine how large a patch would have to be in order to contain areas beyond the influence of edge effects, Laurance \& Yensen (1991) created the "Core-area model”, in which a fragment is divided into a "core” and an "edge" zone, corresponding to the distance to which the transition zone penetrates a fragment (Fig. 2a). This core-area model is simple and intuitive, but assumes the core and edge zones of a fragment are homogenous. This assumption has been challenged by studies showing that edge effects are additive; edge zones near two or more habitat edges experience stronger edge effects than edge zones close to only one edge (Fig 2b)(Malcolm, 1994). More recently, it was discovered that the magnitude and extent of edge effects change consistently with the size of the fragment being studied (Ewers et al. 2007, Fig. 2c). Because of this synergy it is now becoming apparent that edge effects might be one of the major causes of area effects in fragmented landscapes (Ries et al., 2004; Ewers \& Didham, 2007). (See also: Landscape Ecology; Islands)

$<$ Figure 2 near here $>$ 


\section{2 - Diversity in ecosystem boundaries}

Anthropogenic ecosystem boundaries were initially viewed as having a positive influence on species. This notion originated with Aldo Leopold (1933) who noticed a higher diversity of game species near habitat edges and suggested that creating more boundaries would be an appropriate wildlife management strategy. The pattern of increased species richness at habitat edges has now been observed in a wide range of ecosystems (Ewers \& Didham, 2006a). However, this peak in diversity at edges is not necessarily caused by a beneficial effect of edges per se, but often results from an overlap of species from the communities inhabiting the adjacent habitats forming the boundary (Ås, 1999; Ewers \& Didham, 2006a).

As more evidence has become available, this initial view of edges as having a positive impact on diversity has been largely reversed (Laurance, 2008). Many individual species have been shown to be negatively affected by edges either directly or indirectly (See: Species interactions), with several studies showing that various species of plants, arthropods, amphibians, reptiles, birds and mammals either avoid, or have a reduced abundance near habitat edges (Ewers \& Didham, 2006a; Laurance, 2008). Yet despite the large number of species that are negatively impacted by proximity to habitat edges, the invasion by species from a matrix community into a fragment edge often overrides the loss of species from a fragment community, resulting in higher species diversity at edges (Ewers et al., 2007). The important point is that while there may be a greater number of species present at a habitat edge, the combination of species present at edges is very different to the one found in undisturbed habitats, and a wide range of species that are sensitive to the altered ecological conditions at the edge are lost.

It is a difficult, if not impractical, task to predict which species might be sensitive to habitat edges and which are not. For instance, Didham et al. (1998) found 
that two beetle species from the genus Araptus had very different responses to the habitat edges of Central Amazonia; one species was apparently insensitive to edges while the other avoided edges and only occurred deep inside forest. Such variable responses to edges among closely related species have created the notion that edges do not have a consistent effect on species (Fahrig, 2003). However, edge effects are far from random and ecological and life-history traits can be used to predict species responses to habitat edges. In general, there is a suite of characteristics that is generally hypothesised to increase species vulnerability to edges, such as high dispersal ability, forest dependence and open-matrix intolerance (Imbeau et al., 2003; Ewers \& Didham, 2006a). However, the exact set of characteristics conferring susceptibility to habitat edges varies among taxa. In a meta-analysis of studies on habitat edges from North America, Brand (2004) found that bird species are more prone to be sensitive to forest edges if they require mesic conditions, have smaller body sizes, are less ecologically plastic, and have longer incubation and nestling periods. Butterflies, on the other hand, are more sensitive to edges if they are more vulnerable to predation and are lighter in colour, which makes them more sensitive to micro-climatic conditions (Ries et al., 2004).

Ries et al. (2004) presented a predictive model of species responses to edge effects that takes into the account the relative distribution of resources in the two neighbouring habitats and the resource requirements of individual species (Fig. 3). In this model, species are predicted to be most abundant at edges if the resources in the adjacent habitats forming the edge are complementary. For example, species such as the brown-headed cowbird (Molothrus ater) increase in abundance at edges because the individuals use the forest to parasitize nests but forage in open fields. By contrast, 
species that depend on the resources provided in just one of the two adjacent habitats are predicted to decrease in abundance near edges.

$<$ Figure 3 near here $>$

\section{3 - Abiotic changes and their effects on ecological processes at habitat edges}

The creation of habitat edges generates a new combination of environmental conditions by changing the amount of sunlight, wind, temperature and humidity (Murcia, 1995). These abiotic alterations occurring at habitat edges affect a myriad of ecological processes such as recruitment, germination, survival, immigration and emigration. Here, we focus on how such abiotic changes directly affect plant ecology. We discuss indirect effects and how animals are affected by edges in Species Interactions.

In undisturbed forests, typically 1 to $3 \%$ of sunlight reaches the floor but most plant species cannot grow and reproduce under those circumstances (Chazdon \& Fetcher, 1984). For this reason, natural treefall gaps play a major role in the regeneration of tropical forests, and thus, it is not surprising that there is a great increase in productivity when the understory at edges receive from 15 up to $100 \%$ of sunlight (Denyer et al., 2006). This increase in photosynthetically active radiation in the lower levels of the forest is the main factor responsible for the thickening of the foliage and vegetation structure that is distinctive of forest edges, but is also partially responsible for elevated recruitment of pioneer species at edges (Laurance et al., 1998). Another rare event in the lower strata of undisturbed forests is the occurrence of strong winds, but habitat edges are exposed to increased windspeed and turbulence (Chen et al., 1992). Strong winds striking forest edges cause a substantial loss of aboveground biomass at forest edges (Laurance, 2008), and also generate an increase in downwind 
turbulence which results in elevated forest structural damage, windthrow and gap formation. It is not only strong winds that affect forest edges. Even relatively weak winds can affect the forest structure by dropping wind-transported particles at habitat edges, which can result in higher invasion rates by weedy and pioneer species (Cadenasso \& Pickett, 2001; Duncan et al., 2008), or elevated concentrations of nutrients and pollutants at forest edges (Weathers et al., 2001).

It is often interactions between multiple abiotic factors that are responsible for changes to ecological processes and communities at edges. Forest edges, for instance, have typically higher temperatures than deep inside undisturbed forest (Kapos, 1989; Denyer et al., 2006). The combination of elevated temperature and wind speed at edges results in decreased humidity (Camargo \& Kapos, 1995), while the combination of higher temperatures and lower humidity at forest edges results in elevated seed desiccation, lower seedling and sapling survival rates, higher mortality of adult trees, and an increase in fire frequency (Laurance, 2008). Because of these important interactions, Didham et al. (1998) noted that "distance to edge” acting as a composite variable was a better predictor of changes in arthropod community composition than any single environmental variable alone. The same concept applies to ecological processes. For instance, decreased humidity at forest edges can increase rates of leaf fall and the mortality of adult trees. Windthrow of live and dead trees is more common at edges than in continuous forest because of the higher wind speed and turbulence at edges. Wind can also transport propagules of weedy and pioneer species, facilitating their invasion across forest edges. Disruptions to the forest canopy from wind damage, leaf fall and an accelerated rate of wind-driven gap formation, combined with proximity to the edge itself allows more sunlight to reach the forest floor, promoting the recruitment of pioneer species. Given a sufficient amount of time for these processes to 
occur, forest edges tend towards a vegetation composition and structure that is analogous to those of early-successional systems (Tabarelli et al., 2008).

\section{4 - Mediation of cross-system flows}

Neighbouring ecosystems experience flows of organisms (see: Diversity in ecosystem boundaries), materials and energy (see: Abiotic changes) across the shared boundary (Murcia, 1995). Like any other biological boundary, the rate of ecological flows across ecosystems, and the magnitude and extent to which they occur, is modulated by several factors such as compass orientation, slope inclination, landscape context, the relative area of patch and matrix habitats in a landscape, the degree of contrast between the two habitats, boundary structure and edge permeability (Fig. 4).

Changes in abiotic conditions such as solar radiation, temperature and wind are the primary forces driving edge effects. Thus any feature of the environment that regulates changes in abiotic conditions may also modulate the magnitude and extent of edge effects. For instance, the compass orientation of a boundary can influence the strength of edge effects by altering the amount of exposure to sunlight and this influence, in turn, varies predictably with latitude. In the Northern Hemisphere, southfacing edges are more exposed to sunlight and the opposite is true in the Southern Hemisphere. Similarly, seasonal changes to the solar transit and the inclination and aspect of slopes alter the amount of sunlight entering a forest. Slope inclination also influences the movement rates of matter across the edge. Chemical compounds and fertilizers used in agricultural habitats can be passively transported across habitat edges if the latter are sited downhill or downwind of an agricultural field (Weathers et al., 2001).

$<$ Figure 4 near here $>$ 
The strength of edge effects is also dependent on the landscape context. Donovan et al. (1997) reported that the rates of nest predation by brown-headed cowbirds (Molothrus ater) at habitat edges were only detected in moderately to highly fragmented landscapes. Similarly, the relative area of the habitats forming the edge is an important element, with the dominant direction of ecological flows depending on the proportional dominance of one of the habitats within a landscape. For instance, the influence of the edge created by a treefall gap on a continuous forest is small and in a relatively short time period this gap will be filled with regrowth and so the ecological flows from the forest to the gap will be much larger than in the opposite direction. But in large scale disturbances, where thousands of hectares of forest are replaced by an agricultural matrix, the relative proportion of matrix and fragment habitats is reversed and the matrix will exert a much stronger influence on forest patches.

Although all ecosystems can be affected by the creation of edges, some are likely to be more affected than others depending on the relative similarity of the two habitats. For example, there is a remarkable contrast in ecological characteristics between a forest and a grassland, but relatively little contrast at the boundary between a natural and plantation forest or between a natural grassland and managed pasture. In general, the greater the contrast between two habitats, the stronger the edge effects are expected to be (Fig. 4).

Vegetation structure at a habitat edge is a key determinant influencing the extent and magnitude of edge effects (Cadenasso \& Pickett, 2001). Didham \& Lawton (1999) presented strong evidence highlighting the importance of vegetation structure for regulating microclimate, by showing that the width of the transition zone for air temperature and evaporative water loss was narrower when dense vegetation had "sealed" the edge. Such closed edges reduce the distance over which edge-induced 
micro-climatic changes occur, as well as filtering atmospheric pollutants and the influx of seeds of weedy species that invade habitat edges (Cadenasso \& Pickett, 2001; Weathers et al., 2001).

Habitat edges are zones of transition that can slow or redirect flows of materials, energy and organisms between adjacent ecosystems. It has been proposed, however, that ecosystem boundaries should not be seen as an independent landscape component, but as the one side of a "flow regulation" gradient that has habitat corridors at the opposite end (Puth \& Wilson, 2001). Puth \& Wilson (2001) suggest that while edges can stop or reflect ecological flows, habitat corridors channel them, and that any single structure can function as a corridor or a boundary depending on the flow. For instance, a forestfield interface can act as a habitat edge for forest-dependent species, reflecting these organisms back to the forest patch, but as a corridor for edge-specialist species, channeling these species along the edge.

\section{5 - Species interactions}

Species interactions are sometimes intensified near ecosystem boundaries due to the mixing of species from the two adjacent ecosystems. For example, a spatial overlap between the nesting patterns of hawksbill sea turtles (Eretmochelys imbricata) and the foraging patterns of mongooses (Herpestes javanicus) leads directly to an intensification of hawksbill nest predation at the boundary between foreshore vegetation and open sand (Leighton et al., 2008). Similarly, many bird species experience reduced reproductive success near forest edges due to an increase in predation or nest predation rates (Chalfoun et al., 2002). Yet despite the increased predation risk, many species preferentially use habitat edges for nesting. This combination of reduced reproductive success, yet a clear preference to nest near habitat edges, suggests that edges may 
function as an "ecological trap", and evidence to base this notion has been presented for a wide range of organisms such as birds, sea turtles and plants at both natural and anthropogenic ecosystem boundaries (Lahti, 2001; Asquith \& Mejía-Chang, 2005; Leighton et al., 2008). Although most of the evidence comes from vertebrates, there are also studies showing that species interactions involving insects can also be altered at habitat edges. For example, the mantid Stagmomantis limbata preferentially deposits oothecae (egg cases) near habitat edges where bird predation rates are high (Ries \& Fagan, 2003), and the holly leaf-miner Phytomyza ilicis has lower survivorship at habitat edges due to an interaction with host plants (McGeoch \& Gaston, 2000)

\section{6 - Conclusion}

Ecosystem boundaries are zones of transition where organisms, energy and materials flow from one ecosystem to another. When boundaries occur naturally, the end result is a habitat that presents unique environmental conditions which a proportion of species from both adjoining ecosystems can tolerate, and for this reason there can be a local increase in biodiversity at ecological boundaries. When boundaries are created anthropogenically there is often a disruption to, or modification of, ecological processes which affect many species, some positively and some negatively. The exact influence of habitat boundaries on species can be mediated by a wide range of variables that modify the degree to which materials and energy flow across the boundary, and by species interactions that can intensify near habitat edges. 


\section{References}

Ås, S. (1999) Invasion of matrix species in small habitat patches. Conservation Biology, $3,1$.

Asquith, N. M. \& Mejía-Chang, M. (2005) Mammals, edge effects, and the loss of tropical forest diversity. Ecology 86: 379-390.

Brand, L. A. (2004) Prediction and assessment of edge response and abundance for desert riparian birds in southeastern Arizona. PhD Thesis. Colorado State University, Fort Collins.

Cadenasso, M. L. \& Pickett, S. T. A. (2001) Effect of edge structure on the flux of species into forest interiors. Conservation Biology 15: 91-97.

Cadenasso, M. L., Traynor, M. M., \& Pickett, S. T. A. (1997) Functional location of forest edges: gradients of multiple physical factors. Canadian Journal of Forest Research 27: 774-782.

Camargo, J. L. C. \& Kapos, V. (1995) Complex edge effects on soil-moisture and microclimate in Central Amazonian forest. Journal of Tropical Ecology 11: 205221.

Chalfoun, A. D., Thompson, F. R., III, \& Ratnaswamy, M. J. (2002) Nest predators and fragmentation: a review and meta-analysis. Conservation Biology 16: 306-318.

Chazdon, R. L. \& Fetcher, N. (1984) Photosynthetic light environments in a lowland tropical rainforest in Costa Rica. Journal of Ecology 72 553-564.

Chen, J., Franklin, J. F., \& Spies, T. A. (1992) Vegetation responses to edge environments in old-growth Douglas-fir forests. Ecological Applications 2: 387-396.

Denyer, K., Burns, B. R., \& Ogden, J. (2006) Buffering of native forest edge microclimate by adjoining tree plantations. Austral Ecology 31: 478-489.

Didham, R. K., Hammond, P. M., Lawton, J. H., Eggleton, P., \& Stork, N. E. (1998) Beetle species responses to tropical forest fragmentation. Ecological Monographs 68: 295-323.

Didham, R. K. \& Lawton, J. H. (1999) Edge structure determines the magnitude of changes in microclimate and vegetation structure in tropical forest fragments. Biotropica 31: 17-30.

Donovan, T. M., Jones, P. W., Annand, E. M., \& Thompson, F. R., III (1997) Variation in local-scale edge effects: mechanisms and landscape context. Ecology 78: 20642075.

Duncan, D., Dorrough, J., White, M., \& Moxham, C. (2008) Blowing in the wind? Nutrient enrichment of remnant woodlands in an agricultural landscape. Landscape Ecology 23: 107-119. 
Ewers, R. M. \& Didham, R. K. (2006a) Confounding factors in the detection of species responses to habitat fragmentation. Biological Reviews 81: 117-142.

Ewers, R. M. \& Didham, R. K. (2006b) Continuous response functions for quantifying the strength of edge effects. Journal of Applied Ecology 43: 527-536.

Ewers, R. M. \& Didham, R. K. (2007) The effect of fragment shape and species' sensitivity to habitat edges on animal population size. Conservation Biology 21: 926936.

Ewers, R. M. \& Didham, R. K. (2008) Pervasive impact of large-scale edge effects on a beetle community. Proceedings of the National Academy of Sciences of the United States of America 105: 5426-5429.

Ewers, R. M., Thorpe, S., \& Didham, R. K. (2007) Synergistic interactions between edge and area effects in a heavily fragmented landscape. Ecology 88: 96-106.

Fahrig, L. (2003) Effects of habitat fragmentation on biodiversity. Annual Review of Ecology, Evolution and Systematics 34: 487-515.

Fonseca, C. R. \& Joner, F. (2007) Two-sided edge effect studies and the restoration of endangered ecosystems. Restoration Ecology 15: 613-619.

Imbeau, L., Drapeau, P., \& Monkkonen, M. (2003) Are forest birds categorised as "edge species" strictly associated with edges? Ecography 26: 514-520.

Kapos, V. (1989) Effects of isolation on the water status of forest patches in the Brazilian Amazon. Journal of Tropical Ecology 5: 173-185.

Lahti, D. C. (2001) The "edge effect on nest predation" hypothesis after twenty years. Biological Conservation 99: 365-374.

Laurance, W. F. (2008) Theory meets reality: how habitat fragmentation research has transcended island biogeographic theory. Biological Conservation 141: 1731-1744.

Laurance, W. F., Ferreira, L. V., Rankin-de Merona, J. M., Laurance, S. G., Hutchings, R. W., \& Lovejoy, T. E. (1998) Effects of forest fragmentation on recruitment patterns in Amazonian tree communities. Conservation Biology 12: 460-464.

Laurance, W. F. \& Yensen, E. (1991) Predicting the impacts of edge effects in fragmented habitats. Biological Conservation 55: 77-92.

Lehtinen, R. M., Ramanamanjato, J. B., \& Raveloarison, J. G. (2003) Edge effects and extinction proneness in a herpetofauna from Madagascar. Biodiversity and Conservation 12: 1357-1370.

Leighton, P. A., Horrocks, J. A., Krueger, B. H., Beggs, J. A., \& Kramer, D. L. (2008) Predicting species interactions from edge responses: mongoose predation on hawksbill sea turtle nests in fragmented beach habitat. Proceedings of the Royal Society B: Biological Sciences 275: 2465-2472.

Leopold, A. (1933) Game management. Charles Scribner's Sons, New York. 
Malcolm, J. R. (1994) Edge effects in Central Amazonian forest fragments. Ecology 75: 2438-2445.

McGeoch, M. A. \& Gaston, K. J. (2000) Edge effects on the prevalence and mortality factors of Phytomyza ilicis (Diptera, Agromyzidae) in a suburban woodland. Ecology Letters 3: 23-29.

Murcia, C. (1995) Edge effects in fragmented forests - Implications for conservation. Trends in Ecology and Evolution 10: 58-62.

Puth, L. M. \& Wilson, K. A. (2001) Boundaries and corridors as a continuum of ecological flow control: Lessons from rivers and streams. Conservation Biology 15: 21-30.

Ries, L. \& Fagan, W. F. (2003) Habitat edges as a potential ecological trap for an insect predator. Ecological Entomology 28: 567-572.

Ries, L., Fletcher, R. J., Jr., Battin, J., \& Sisk, T. D. (2004) Ecological responses to habitat edges: mechanisms, models and variability explained. Annual Review of Ecology, Evolution and Systematics 35: 491-522.

Tabarelli, M., Lopes, A. V., \& Peres, C. A. (2008) Edge-effects drive tropical forest fragments towards an early-successional system. Biotropica 40: 657-661.

Walker, S., Wilson, J. B., Steel, J. B., Rapson, G. L., Smith, B., King, W. M., \& Cottam, Y. H. (2003) Properties of ecotones: Evidence from five ecotones objectively determined from a coastal vegetation gradient. Journal of Vegetation Science 14: 579-590.

Weathers, K. C., Cadenasso, M. L., \& Pickett, S. T. A. (2001) Forest edges as nutrient and pollutant concentrators: potential synergisms between fragmentation, forest canopies, and the atmosphere. Conservation Biology 15: 1506-1514. 


\section{Further Reading list}

Laurance, W. F., and R. O. Bierregaard, Jr. 1997. Tropical Forest Remnants: Ecology, management, and conservation of fragmented communities. The University of Chicago Press, Chicago.

Laurance, W. F., R. K. Didham, and M. E. Power. 2001. Ecological boundaries: a search for synthesis. Trends in Ecology and Evolution 16:70-71.

Lindenmayer, D. \& Fische, J. 2006. Habitat Fragmentation and Landscape Change: An Ecological and Conservation Synthesis. Island Press, Washington.

\section{Glossary:}

Edge species - edge species are organisms that have higher density at habitat edges than in either of the two habitats that abut to form the edge. Related terms are: interior species that are organisms that occur in higher densities in the natural habitat; matrix species that are organisms that occur in higher densities in the matrix and edge-neutral species that do not show any specific response to the presence of habitat edges.

Edge habitat -edge habitat is the habitat falling within the zone of transition across a habitat boundary in which edge effects can be detected. A related term is interior habitat which is areas that are not impacted by edge effects. The extent of edge habitats is process and species-specific, such that an area that represents an edge habitat for one species might represent an interior habitat for another.

Closed edge - in contrast to open edge, closed edges are habitat edges with a dense vegetation structure. Closed edges are often found in old edges where regrowth has sealed the edge or in cases when the structural difference between the adjacent habitats forming the edge is small and has low contrast. 


\section{Figure Legends}

Figure 1 - Examples of four ecosystem boundaries. (a) Natural ecosystem boundaries occur between a tropical evergreen and riparian forest, and between the riparian forest and the river that it borders. (b) Natural boundaries occur across the gradient from marine to intertidal to foreshore environments near the shore in temperate coastal regions. (c) Anthropogenic boundaries occur between the ginger plantation and the yam plantation, and between the latter and the tropical secondary-forest. (d) Anthropogenic boundaries occur between a planted forest and an open field in a temperate region.

Figure 2 - Representation of edge effects on habitat fragments. (a) The Core-area model of Laurance and Yensen (1991) showing the edge zone (light green) as a distinct and homogenous habitat that differs from the core zone (dark green). (b) The additive effects model of Malcolm (1994) showing that edge zones adjacent to two edges are more heavily impacted (lightest green) than edge zones near just one edge (intermediate green). (c) The proportion of a habitat fragment that is impacted by edges decreases as patch size increases, with progressively lighter shades of green representing areas more heavily impacted by the habitat edge.

Figure 3 - The predictive model of edge effects built by Ries et al. (2004) to explain changes in the abundance of species near habitat edges based on resource distribution. (a) When resources are concentrated in one habitat and those in the adjacent habitat are supplementary (where resources from one habitat can be substituted by resources from the other) but of a lower quality, a transitional decline in abundance across the habitat edge is predicted. (b) However, when resources in the lower quality habitat are 
complementary to those in the higher quality habitat (the low quality habitat provides resources that are required by the species but are not present in the high quality habitat), then being on the edge allows maximum access to the resources contained in both habitats resulting in an increased abundance near the edge. When resource availability is relatively equal between patches, a neutral response is predicted when (c) resources are supplementary, and a positive one when (d) resources are complementary. When (e) resources are concentrated along the edge, a positive response is once again predicted. Figure reproduced by permission of Leslie Ries and Annual Reviews.

Figure 4 - Schematic representation of cross-system flows between adjacent habitats in a tropical landscape disturbed by human use. Arrows represent the direction of crosssystem flows and arrow thickness represents the magnitude of edge effects. (a) Edge effects between a mature tropical forest and a clear-cut area are very strong, whereas in (b) edge effects between mature and early successional forest are weaker. (c) Edge effects between early successional forest and unmaintained pasture are expected to be weak, as are those between (d) unmaintained pasture and a clear-cut. (e) Edge effects between early successional forest and clear-cut area are expected to be strong, although less than those between the clear-cut and mature forest. 
Figure 1

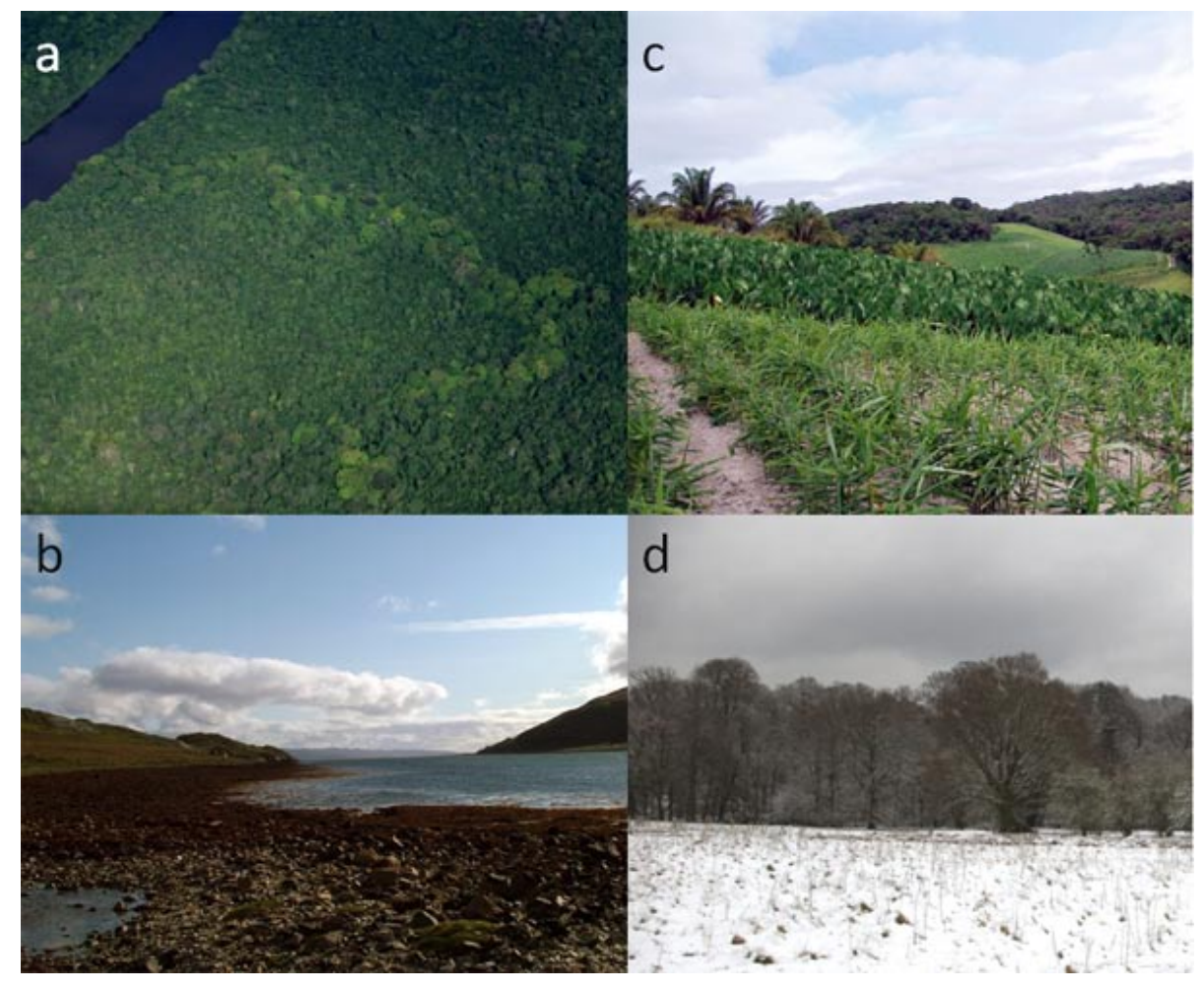


Figure 2
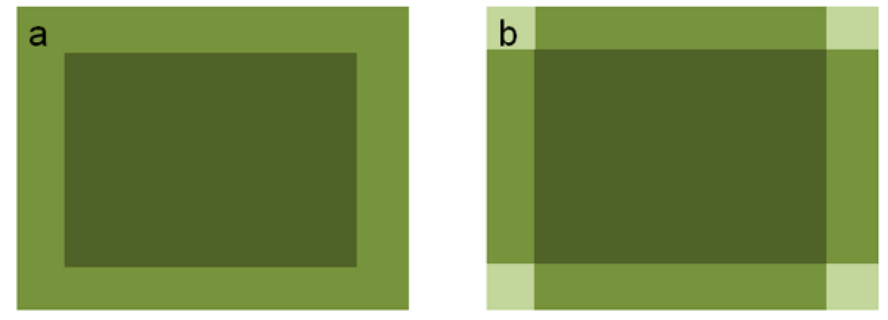

C
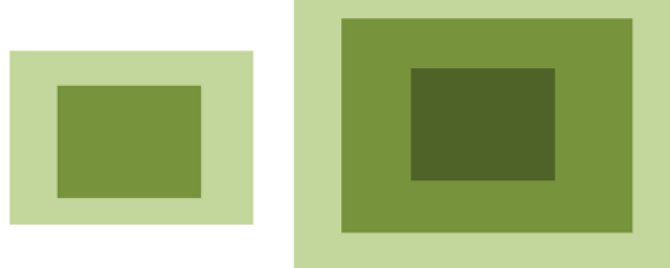

Patch size 
Figure 3

\section{Edge \\ between:}
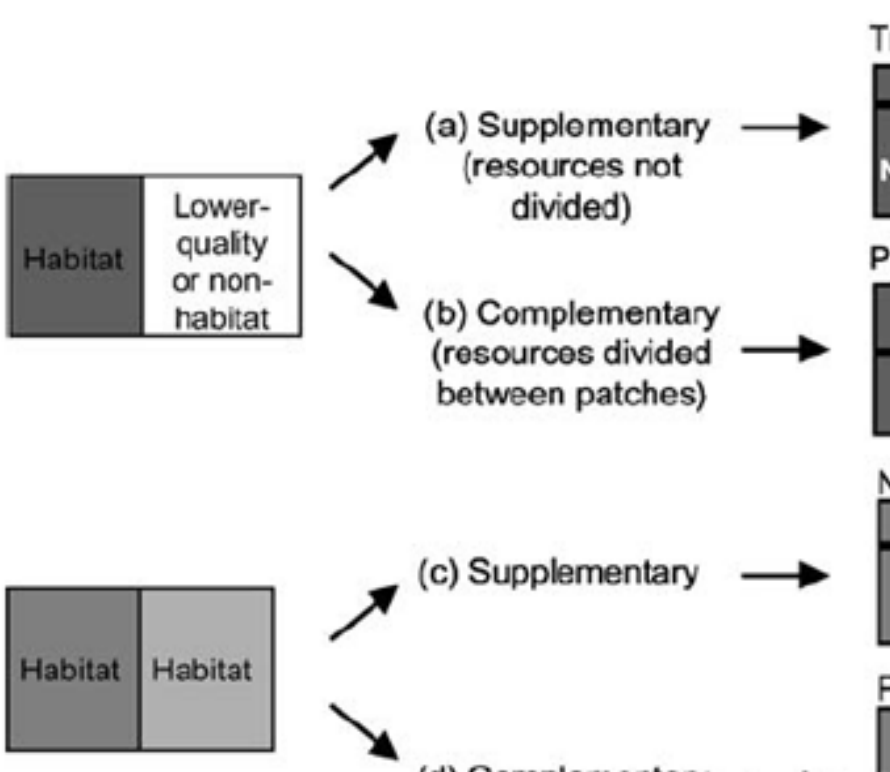

(c) Supplementary

(d) Complementary

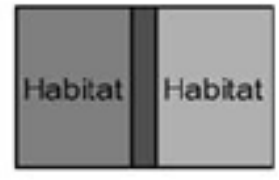

(e) resources

concentrated at edge

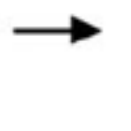

Resource

distribution:

Predicted

edge response:

Transitional

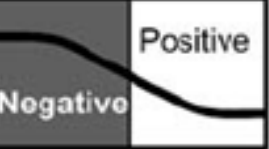

Positive

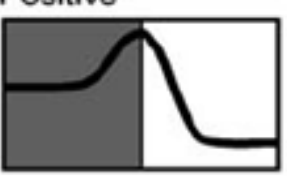

Neutral

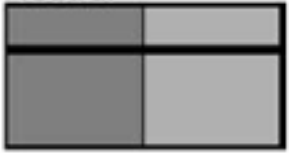

Positive

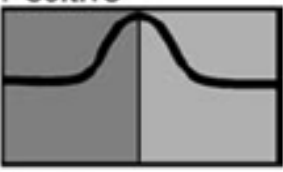

Positive

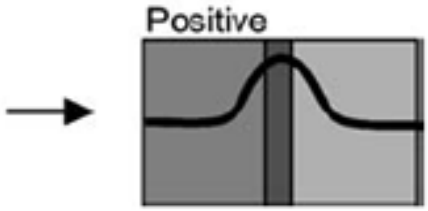


Figure 4

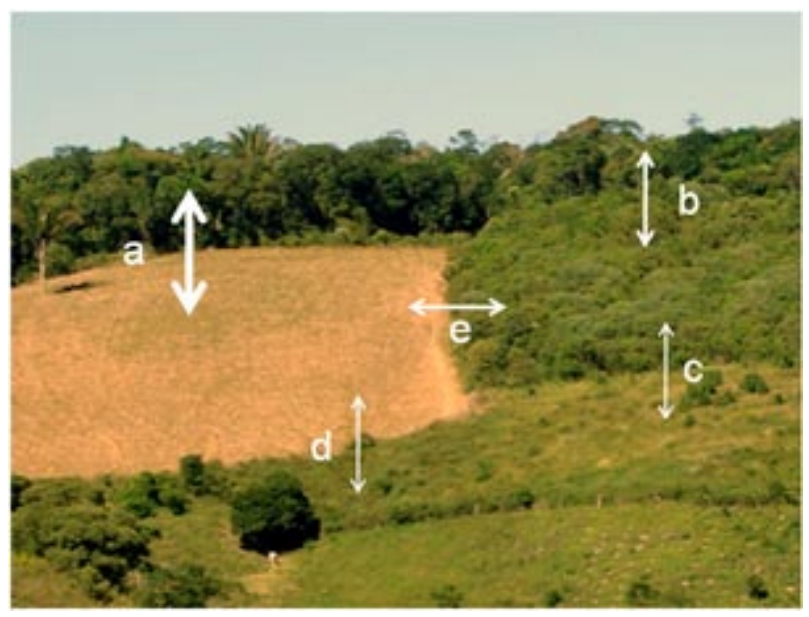




\section{Capítulo 3}

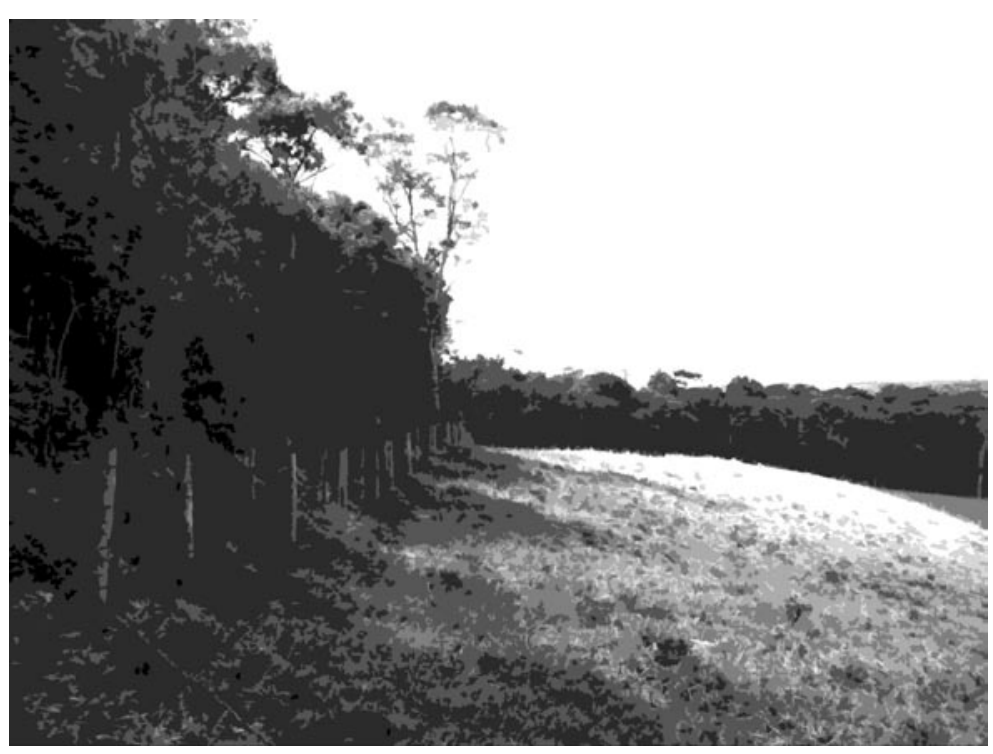




\section{Capítulo 3}

Edge effects as the principal cause of area effects on birds in fragmented secondary forest

Cristina BANKS-LEITE, Robert M. EWERS \& Jean-Paul METZGER 


\section{Resumo}

A comunidade de aves em florestas tropicais é fortemente afetada tanto pela área de fragmentos florestais quanto por efeitos de borda. Apesar de acreditar-se que seja diferente a forma como efeitos de borda e de área de fragmento influenciam as espécies, o fato de que ambos estes efeitos são altamente correlacionados espacialmente levanta questões como: como se dá a interação entre estes dois padrões ecológicos? E seriam eles independentes ou apenas duas diferentes manifestações espaciais do mesmo fenômeno? Além disso, será que fragmentos pequenos compostos por vegetação secundária, localizados em paisagens onde a maioria das espécies sensíveis já foi extinta localmente, exibiriam efeitos de área e de borda similares aos já encontrados em regiões de floresta primária? Para responder estas perguntas, nós testamos se haviam diferenças na estrutura de vegetação e composição da comunidade entre bordas e áreas no interior de fragmentos em 31 sítios localizados em paisagens fragmentadas e contínuas de Mata Atlântica. As aves foram capturadas com o uso de redes de neblina, sendo que cada sítio foi amostrado por 680 horas-rede, o que resultou em um total aproximado de 22,000 horas-rede e 3,381 indivíduos capturados ao longo de dois anos. Os resultados mostram que a comunidade de aves em fragmentos de vegetação secundária era mais pobre que aquela encontrada em matas contínuas adjacentes, mas ainda era bastante influenciada por efeitos de borda. Em paisagens fragmentadas compostas por florestas secundárias, os efeitos de área e de borda também interagiram, uma vez que a magnitude da diferença na composição de espécies entre borda e interior diminuía significativamente com a redução de área de fragmento. A mudança na composição de espécies de aves entre áreas de borda e interior florestal foi similar à mudança a encontrada entre fragmentos grandes e pequenos (uma vez que as espécies apresentaram respostas congruentes entre efeitos de área e de borda). No entanto, ao fixar experimentalmente os efeitos de borda, a variação em área de fragmento deixou de influenciar a composição da comunidade de aves. Assim, nossos resultados mostram que apesar de florestas secundárias apresentarem uma comunidade de aves empobrecida, padrões ecológicos, como os efeitos de área e de borda, encontrados em florestas secundárias são similares aos encontrados em áreas de matas primárias. Nós também apresentamos evidências de que efeitos de borda são as principais causas dos efeitos de área em paisagens fragmentadas. 


\section{Summary}

Bird communities in tropical forests are strongly affected by both patch area and habitat edges. Although the underlying causes for edge and area effects on species may be different, the fact that both effects are intrinsically confounded in space raises questions about how these two widely reported ecological patterns interact, and are they independent or simply different spatial manifestations of the same phenomenon? Moreover, do small patches of secondary forest, in landscapes where the most sensitive species have gone locally extinct, exhibit similar patterns to those previously observed in fragmented and continuous primary forests? We addressed these questions by testing edge-related differences in vegetation structure and bird community composition at 31 sites in fragmented and continuous landscapes in the imperilled Atlantic forest of Brazil. Over a two-year period, birds were captured with mist nets to a standardized effort of 680 net-hours at each site ( 22,000 net-hours resulting in 3,381 captures). We found that the bird community in patches of secondary forest was degraded in species composition compared to primary continuous forest, but still exhibited a strong response to edge effects. In fragmented secondary forests, edge and area effects also interacted, such that the magnitude of edge to interior differences on bird community composition declined markedly with patch size. The change in bird species composition between forest interiors and edges was similar to the change in community composition between large and small habitat patches (a result caused by individual species having congruent responses to edge and area), but after controlling for edge effects community composition was no longer affected by patch area. Our results show that although secondary forests hold an impoverished bird community, ecological patterns such as area and edge effects are similar to those reported for primary forests. We also provide further evidence that edge effects are the main drivers of area effects in fragmented landscapes.

Key-words: edge avoidance, fragmentation, rainforest, species-area relationship, understory birds.

Running head: EDGE EFFECTS CAUSE AREA EFFECTS ON BIRDS 


\section{1 - Introduction}

Of the $11,000,000 \mathrm{~km}^{2}$ of surviving tropical forest in the world, half is degraded and in various stages of secondary regrowth (Wright, 2005). In some countries, such as Puerto Rico and Costa Rica, the area of secondary forest is now larger than that of old-growth forest (Wright \& Muller-Landau, 2006). Because much old-growth forest is steadily being converted into regrowth, the role of secondary forests in conserving forest biodiversity has become a hotly debated topic. Some claim that, as primary forests decline, most forest species will be able to persist in regrowth, which will buffer them from extinction (Wright \& Muller-Landau, 2006); this assertion is supported by evidence that secondary forests can either promote recolonization of isolated primary patches or function as habitat for some forest-specialist species (Stouffer \& Bierregaard, 1995b; Pardini et al., 2005). However, others believe that species richness and composition in tropical secondary forest is usually much different from that in primary forests, and that secondary forests should be regarded as suitable habitat only for a limited subset of forest species (Barlow et al., 2007; Gardner et al., 2007; Laurance, 2007). This latter contention is supported by analyses showing that the ability of bird species to use secondary habitats in the tropics does not reduce their risk of becoming extinct from deforestation (Harris \& Pimm, 2004). Given the postulated central role that secondary forests may play in the long-term preservation of tropical biodiversity, it is essential to understand how species respond to these habitats and whether secondary forests maintain similar ecological communities, patterns and processes as those described for primary forests.

Edge effects have been reported as one of the most important patterns structuring both flora and fauna of primary tropical forests (Didham et al., 1998; Restrepo \& Gomez, 1998; Oliveira et al., 2004; Pardini, 2004). However, there are at 
least three reasons for thinking that small patches of secondary forests should have weaker edge effects than in primary forests. First, many areas of secondary forest are a patchwork of regrowth of varying ages, such that a patch can be partly composed of light-demanding tree species which are positively affected by edges, and by juveniles of shade tolerant species which are negatively affected (Oliveira et al., 2004; Laurance et al., 2006; Teixeira et al., 2009), thus complicating the detection of a general trend of edge effects on the plant community. Second, the species that are expected to be most sensitive to edge effects are no longer present in fragments of secondary forest. Soon after isolation, many bird species disappear from remnant habitat patches as they may be reluctant to cross open areas, unable to survive in small fragments or to withstand changes in vegetation structure (Stouffer \& Bierregaard, 1995b; Ferraz et al., 2003; Moore et al., 2008). Thus, only the species with the ability to cross edges and open areas, and then to survive in disturbed vegetation, are expected to be found in secondary forest patches. Lastly, small fragments are unlikely to exhibit detectable edge effects because synergies between edge and area effects complicate their detection (Malcolm, 1994; Ewers \& Didham, 2006). Small patches have high perimeter/area ratios and the centre of those patches are consequently affected by multiple edges in such a way that they do not have a true interior (Malcolm, 1994), with the implication that community composition should not vary between the patch edge and interior. This reasoning has led to the suggestion that species found in small patches, or that otherwise benefit from deforestation or forest fragmentation, have a preference for edge habitats (Anjos \& Bocon, 1999; Sekercioglu et al., 2002). If this is correct, then we would expect to find a high congruence between species responses to edge and area; i.e., species that are more abundant at edges should also be more abundant in small patches (Fletcher et al., 2007). 
Although patch area and edges might affect species for different reasons (Fletcher et al., 2007), the fact that species may have congruent responses to these two effects suggests that their influence on communities may be analogous due to a possibly causal association between the two effects. This idea is supported by analyses showing that much of the correlation between patch area and community structure can be caused by edge effects (Ewers et al., 2007; Fletcher et al., 2007) and that area-related gradients in population size and density can be generated by edge effects alone (Ewers \& Didham, 2007). Many ecological studies confound the effects of patch area and edges (Fletcher et al., 2007) and there are few studies that have rigorously and purposefully attempted to separate the effects of the two variables. One outstanding question then is whether species are responding in a similar way to edge and area gradients, and after controlling for edge effects, are they still affected by area? The question has considerable importance: area effects, such as the species-area relationship, are considered one of the few ecological laws and form the basis of island biogeography theory (MacArthur \& Wilson, 1967), which has also strongly influenced much of the disciplines of landscape ecology (Haila, 2002) and conservation biology. If species responses to edge and area effects are correlated or even causally associated, then actions to mitigate area effects without considering edge effects would most likely be ineffective.

In a world in which tropical primary forest is coming under increasing threat from human encroachment (Millennium Ecosystem Assessment, 2005), where secondary forests are becoming progressively more abundant (Wright \& MullerLandau, 2006) and where most ecosystems are fragmented to varying degrees (Riitters et al., 2000), it is of utmost importance to evaluate how ecological communities are structured in secondary forest habitats. To address this issue, we studied the Atlantic 
forest of Brazil, one of the most endangered biomes in the world with less than $16 \%$ of the original area remaining and that being mainly comprised of secondary vegetation scattered in patches smaller than 50 ha (Ribeiro et al., 2009). This biome has a high rate of species endemism (Cincotta et al., 2000) and the most threatened avifauna in the Americas (Manne et al., 1999). In this study we addressed two main questions: (1) Do bird communities show similar patterns of responses to habitat fragmentation in secondary forests as those previously reported for primary forest? To address this issue, we evaluated whether secondary forest patch edges differ from patch interiors in vegetation structure or in the richness and abundance of understory birds and functional groups. (2) Are edge and area effects on bird species functionally similar and even causally associated? This issue was addressed by assessing: (a) how the strength of edge effects is related to patch size; (b) whether gradients in bird communities across forest edges are similar to gradients across patch sizes, and if controlling for edge effects would remove a significant effect of area on community composition; and (c) if species show concordant responses to edge and area effects.

\section{2 - Methods}

Study area

Field work was conducted in the Atlantic Plateau of the State of São Paulo, Brazil. Altitude in this area ranges from $750 \mathrm{~m}$ to $1000 \mathrm{~m}$ above sea level, with a mean annual temperature of $19^{\circ} \mathrm{C}$ and annual rainfall of $1808 \mathrm{~mm}$, and the original vegetation is lower montane rainforest. Sampling was partly conducted in a 10,000 ha fragmented landscape $\left(23^{\circ} 50^{\prime} \mathrm{S}, 47^{\circ} 20^{\prime} \mathrm{W}\right)$, which has $50 \%$ native forest cover in various successional stages (from 20 to over 100 years), $38 \%$ cropland and the remaining is mainly comprised of wetlands, Eucalyptus spp. Plantations and other land uses. We also 
sampled an adjacent forested area, the 26,000 ha State Park of Jurupará, which is connected to a 1 million ha tract of Atlantic forest (Ribeiro et al., 2009). This control area is located just five kilometres from the fragmented landscape. It has historically been subjected to selective logging for hardwood tress and now consists of highly advanced successional stages, with a species composition approaching that of primary forests.

In total, we sampled 31 sites both in the continuous forest (four sites) and in the fragmented landscape (19 patch interiors plus 8 patch edges). Forest patches were selected to reflect the natural variation in patch size and connectivity present in the fragmented landscape. Thus we selected seven small patches ranging from 3 to 5 ha, eight medium-sized patches from 8 to 30 ha and four large patches of 90 to 150 ha. These fragments are composed of a mosaic of different forest successional stages, with a predominance of medium to advanced stages. The four control sites in Jurupará were separated by at least $1.5 \mathrm{~km}$, and were sited at least $400 \mathrm{~m}$ from the nearest forest edge. We sampled in the interior of all 19 patches, and also at the edges of four randomly selected medium patches and at the edges of all four large patches. We standardized edge sites by choosing locations that consisted of a boundary between forest in medium to advanced successional stage and a large expanse of open matrix composed of either croplands or pasture.

\section{Vegetation sampling}

At all 31 sites, we assessed vegetation structure in a $2.5 \times 120 \mathrm{~m}$ plot along a $120-\mathrm{m}$ mist net line. Inside this plot we measured the diameter at breast height of all trees (above $5 \mathrm{~cm} \mathrm{DBH}$ ) and the number of bromeliads in bloom at up to four meters height above ground. We also quantified understory vegetation stratification with 42 foliage 
height profiles in each plot. Every $6 \mathrm{~m}$ along the plot, we sampled two points (one on each side of the path) with a $2.5 \mathrm{~m}$ vertical pole and recorded the 50 -cm height intervals which had vegetation touching the pole. For analysis, we summed the number of records for each of the five height intervals resulting in profiles of foliage height distribution for each plot.

\section{Bird sampling}

Understory birds were sampled using 10 mist nets (12 m length, $2.5 \mathrm{~m}$ high, $31 \mathrm{~mm}$ mesh) positioned end-on-end in a single line. We sampled each site for four sets of two consecutive days, from sunrise to sunset. Each site was sampled twice in the dry season (austral winter of 2005 and 2006) and twice in the wet season (summer of 2005/2006 and 2006/2007), until we had sampled a total of 680 net-hours per site. All captured birds were marked with a numbered aluminium band provided by the Centre of Research for Conservation of Wild Birds (CEMAVE - IBAMA), and released. At patch interior sites, mist nets were positioned 50 meters from the nearest edge (although in small patches mist net lines were inevitably closer to the edge), while at edge sites the mist net line was just 5 meters from the border and followed the edge contour. Because the definition of a "true interior condition" depends on the organism of interest, small patches might not present such conditions and because we did not sample precisely in the centre of each patch, we use the term "interior" to designate sampling sites that were not located at the patch edges. In patches where both the edge and interior were sampled, the two mist net lines were separated by at least $100 \mathrm{~m}$ and were sampled simultaneously.

All birds were identified to species in the field and later categorized into three functional guilds and two habitat specialization categories. The former categorization 
represents the main trophic guilds of understory birds: frugivorous, nectarivorous (hummingbirds) and insectivorous birds, according to Hasui (2003), and the latter divided bird species according to their published responses to human-disturbances (Stotz et al., 1996; Develey, 2004). We refer to species that are negatively affected by human disturbances as sensitive species, and to those that are able to survive in areas of disturbed vegetation as well as in forest patches as generalist species.

\section{Statistical analyses}

To quantify vegetation structure, we calculated the mean and coefficient of variation of $\mathrm{DBH}$, the number of trees and the number of bromeliads inside each plot. For vegetation stratification, we used PCA to summarize the profiles of foliage height distribution into one value per site. Differences between edge and interior sites for vegetation structure were analyzed using Wilcoxon paired-tests since these measures did not conform to any specific distribution. Differences in the bird assemblages were measured as species richness and capture rate (hereafter referred to as abundance, as we excluded all recaptures within the same site from the analysis), and tested for significance using generalised linear mixed models with Poisson errors for nested count data (one-way analysis of deviance).

To understand how the bird community was affected by habitat fragmentation, we conducted a hybrid multidimensional scaling ordination (HMDS), using the BrayCurtis dissimilarity index on untransformed species abundance at all 31 sites. The hybrid MDS was introduced by Faith et al. (1987) and combines both the PCoA (classical MDS) and the non-metric MDS (NMDS). It has the advantage of assuming a linear relationship between the ecological distances obtained by the ordination and the

dissimilarity measures where it is most often straight (the PCoA part), and only 
monotonicity where ecological distances are too high to be accurately measured (the NMDS part) (Faith et al., 1987). Following Laurance et al. (2006), we used the first two axis scores as $x$ and $y$ grid coordinates for each sampling site and then calculated the centroid (the average of the $x$ and $y$ coordinates) for each of the following site categories: large patch interiors, edges and small patch interiors. To estimate the strength of edge effects on community composition, we measured the Euclidean distance between the coordinates of each edge site in the ordination space to each of these three centroids, and also to the interior site located in the same patch. We used one-way ANOVA to test for differences in the Euclidean distances from edge scores to each centroid and analyzed the contrast coefficients to evaluate which differences were significant. For instance, if the mean and standard deviation of the Euclidean distance from edge scores to the edge centroid is significantly lower than to the remaining centroids, this would mean that in the ordination plot all edge sites form a tight group that is isolated from the remaining sites. This approach thus tested for similarity between the bird community found at edges and a generic community as represented by each centroid, such as "edge community”, "small patch community,” and so on.

To evaluate whether edge effects were less marked in medium ( 10 to 40 ha) than large patches (> 90 ha), we used the Euclidean distance between the HMDS scores for the paired edge and interior sites as the response variable in a simple linear regression against patch size. If the strength of edge effects does not vary with patch size, the difference in community composition from the edge to interior within a patch, as represented by the Euclidean distance, should not vary as a function of patch size. In a second step, we calculated a control site centroid and then measured the Euclidean distances from the centroid to the coordinates of each site located in patches. We grouped the sites by patch size (large, medium and small) and edge or interior, then 
tested for differences in the compositional similarities from the control centroid with a one-way ANOVA, and checked which classes were significantly different from each other with contrasts.

Because area and edge effects are intrinsically confounded when sampling communities at the interior of patches, we controlled for such correlations both statistically and by fixing the distance to edge where sampling took place. For that we conducted a series of simple linear regressions. First, we tested for an effect of patch size on the Euclidean distances from the control centroid to the interior sites in small, medium and large patches. In this case area and edge effects are confounded, because the distance of the sampling site to the patch edge increases with patch size. Second, we regressed the Euclidean distances from these same sites against distance to edge (measured as a straight line from the sampling site to the nearest patch edge). We then used the residuals from the second regression and regressed them against patch size, to see if the effect of area remains after the edge effect has been removed. Lastly, we regressed patch size against the Euclidean distances from control to the edge sites in medium patches and large patches, and the interior sites of small patches, which were unavoidably located close to the patch edge. In this case the distance to edge where sampling took place does not increase with patch size and thus any effect on community composition could be attributed to area alone.

To assess the responses of individual species to area and edge effects, we first selected species with more than five individuals recorded and that were captured in more than three out of the eight patches in which we sampled edges. We then fitted a one-way analysis of deviance with Poisson errors for nested data to test for a difference in species abundance at edge vs. interior sites. To test species responses to changes in patch size we used generalised linear models with Poisson errors. For each of the two 
models, we recorded the coefficient estimates as a measure of the species response to that variable, and tested for a linear correlation between the Z-values, obtained from the paired edge-interior differences, and the $\beta$-values, obtained from the models where patch size was the explanatory variable. Because species that increased in abundance in patch interiors received positive Z-values, we hypothesised a positive correlation between the coefficient estimates, i.e., species increasing in abundance in patch interiors will be the ones positively affected by patch size, and vice-versa. All analyses were performed in the R program v2.5.1 (R Development Core Team 2007).

\section{3 - Results}

We recorded a total of 2681 individuals belonging to 114 species from 3,381 captures. The community was numerically dominated by the white-shouldered fire-eye, Pyriglena leucoptera (162 individuals), the swallow-tailed manakin, Chiroxiphia caudata (159) and the black-goggled tanager, Trichothraupis melanops (152). Approximately $50 \%$ of the species captured were endemic to the Atlantic forest and 19 species were captured only in the continuous forest control.

\section{Patch edge versus interior}

We did not find any significant differences between the edges and patch interiors for any measure of vegetation structure (Table 1), nor for total bird species richness and the richness of all guilds except sensitive species, in which species richness was lower at edges (Table 2). There was, however, a significant decrease in the total abundance of the bird community and in the abundances of functional groups of insectivores and sensitive species at edges, while hummingbirds showed a significant increase in abundance at edges (Table 2). 
Community changes at secondary forest edges

The first two axes resulting from an HMDS ordination explained 57\% of the variation in species composition among the 31 sites. Clear gradients in community composition were observed along both axes, with the centroids for control sites and large patches having negative values on both axes and the centroids for small patch interiors and edges having positive values (Fig. 1). The average community dissimilarity between edge sites and large patch interiors was significantly larger than the average dissimilarity among edge sites, between paired edge and interior sites and between edges sites and small patch interiors $\left(F_{3,28}=4.60, P<0.01\right.$, Fig 2$)$. This shows that the edge community (1) did not have a distinctive community consisting primarily of exclusive, edge-specialist species, (2) was not spatially autocorrelated with the community present in its own patch interior, and (3) was statistically similar to the bird community present in small patch interiors.

\section{Interaction between edge and area effects}

The magnitude of edge-related changes in community composition was dependent on patch size. Communities at the edge and interior of large patches differed by a significantly greater amount than communities at the edge and interior of medium sized patches $\left(R^{2}=0.67, F_{1,6}=12.11, P=0.01\right.$, Fig. 3$)$. The difference in compositional similarities from the control centroid was smaller at the interior of large patches than at their edges, which differed from the control community by a similar amount as the community found in small patch interiors $\left(F_{4,22}=5.38, P<0.01\right.$; Fig. $\left.4 \mathrm{~b}\right)$. The community composition sampled at the interior of patches changed significantly with increasing patch area $\left(R^{2}=0.55, F_{1,17}=21.61, P<0.001\right.$, Fig. $\left.4 \mathrm{a}\right)$ and with increasing

distance from the nearest edge $\left(R^{2}=0.43, F_{1,17}=12.83, P=0.002\right)$. However, 
community composition did not change with patch area either when we statistically controlled for the distance to edge $\left(R^{2}=0.04, F_{1,17}=1.56, P=0.22\right)$, or when we controlled edge effects by sampling at a fixed distance to edge in all patches $\left(R^{2}=0.01\right.$, $F_{1,17}=0.19, P=0.667$, Fig. 4a).

\section{Individual species responses to edge and area}

In the patches where we sampled the bird community at both edge and interior sites, we captured 1,368 individuals belonging to 81 species. Of these, 37 species (592 individuals) were captured frequently enough to contrast their numerical responses to habitat edges and patch area. Species were uniformly distributed in their responses to both edge and area. Five species significantly increased in abundance at edges and seven significantly decreased in abundance at edges, while the abundance of eight species was negatively correlated with patch size and 10 species were positively correlated (at $\alpha=0.05$ ). There was a significant positive correlation between species responses to edge and to area $(r=0.417, \mathrm{~N}=37, P=0.008)$, suggesting that species responses to these two spatial variables were concordant (Fig. 5).

\section{4 - Discussion}

In primary Neotropical forests, the vegetation structure at forest edges is markedly different from that in the forest interior (Malcolm, 1994; Harper et al., 2005; Laurance et al., 2006). However, we did not find a similar pattern in the secondary forests of the Atlantic plateau, where patches have been subjected to both selective logging and/or clear-cutting since the beginning of the 1900s. Moreover, different timings of land use change across the region have created a landscape with heterogeneous fragments that vary in successional stage, both within and among patches (Teixeira et al., 2009; 
Metzger et al., 2009). In such a context, it is not surprising that we found no systematic differences in vegetation structure between patch edges and interiors, as it is entirely conceivable that some edge sites could be older than interior sites located in the same patch.

Previous studies have suggested that edge effects on bird communities are mediated in great part through changes in vegetation structure (Restrepo \& Gomez, 1998; Laurance, 2004; Laurance et al., 2004). We would then expect that the lack of edge-related differences in vegetation structure at our study sites, combined with the prior loss of 19 highly sensitive forest specialists from this fragmented landscape, would result in either no edge effects on bird communities, or at least edge effects that are much weaker than those detected in other studies. But this was not the case and our results were similar to those obtained from studies in the primary forest of Amazonia. Species richness is at most weakly affected by habitat edges (Restrepo \& Gomez, 1998; Laurance, 2004), however the insectivorous and sensitive species, and the community as a whole, were less abundant at forest edges while hummingbirds increased in abundance at edges, just as they do in primary forests (Stouffer \& Bierregaard, 1995a; 1995b; Restrepo \& Gomez, 1998; Laurance, 2004).

The combined changes in the abundance of individual species resulted in a shift in community composition at forest edges. But how did this change occur? Edges did not have higher species richness or an assemblage that was distinguished by the invasion of matrix or transient species, such as has been seen with arthropods (Ewers et al., 2007) and birds in temperate forests (Lindell et al., 2007). At forest edges and gaps, canopy-dwelling bird species may descend to the understory (Levey, 1988) and matrix species may likewise ascend to the canopy (CBL, personal observation), but species with both preferences rely upon the foliage-air interface and do not penetrate beneath 
the forest canopy to a great extent. In Amazonia, where there are no native matrix species, edges are dominated by gap and edge specialist species (Restrepo \& Gomez, 1998; Laurance et al., 2004). Unfortunately, in the Atlantic forest we do not have prior knowledge about the treefall gap avifauna and most information about species use of habitat edges is anecdotal, as no previous studies have specifically addressed this issue. However, considering that just six species were exclusively captured at edges (five of which were singletons) and that just five of 37 species increased in abundance at edges, we do not have evidence to conclude that forest edges have a distinct and clearly definable bird assemblage.

Instead, edge effects produced patterns of bird community composition that were functionally and quantitatively similar to area effects. While the bird community present at the interior of large patches had a fairly pristine community (relative to control sites), the community at the edge of large patches was similar to that of small patch interiors (Fig. 4b). A comparable, but weaker, pattern was also seen in medium-sized patches, which had interior communities that differed from those of small patch interiors, but had edge communities that were similar to their own interior and to small patch communities. This result is consistent with the concept of an interaction between area and edge effects. Malcolm (1994) was the first to suggest that a site within a patch would suffer not only from the influence of the nearest edge, but from the summed effect of all surrounding edges which would be more intense in small than in large patches. Recently, Ewers et al. (2007) extended this notion by showing that area and edge effects act synergistically, such that the magnitude of edge to interior differences increases exponentially with patch size. In this study, we found a four-fold increase in the strength of edge effects when patch size increased nine times (Fig. 3). But we only studied edges in patches varying in size from 15 to 145 ha, whereas Ewers et al. (2007) 
sampled patches spanning nine orders of magnitude in size, indicating that we may have captured just a small proportion of the area-related gradient in the strength of edge effects.

It has been suggested that many species are erroneously considered to be edgespecialists as a result of flawed sampling and analyses (Villard, 1998) and that these may in fact be species with preferences for disturbed vegetation (Imbeau et al., 2003). Nevertheless, a recent review by Fletcher et al. (2007) showed that species generally have consistent responses to patch area and edges in that edge-sensitive species are also area-sensitive, and edge-loving species are also generalist specialists: our analyses at the species-level, coupled with the community-level results, corroborated this pattern. In fact, species that are unable to cross open fields or utilize edge habitats will most likely show consistent responses to edge and area. This also explains why we found the strength of edge effects to increase with patch size, as sensitive species, which avoided edges, were only present in large patches. However, as edge and area effects are often intrinsically confounded, it is difficult to know if these sensitive species were responding to area per se or to multiple edge effects.

Fletcher et al. (2007) suggested two ways to control for this potentially confounded correlation at the community level; the best option is to measure responses to area by fixing the distance from the nearest edge, or alternatively one could statistically control for edge effects before testing for area effects. In the present study, we used both methods which yielded the same conclusion; after controlling for the distance to the edge, area did not affect species composition, suggesting that edge effects might be in fact the main driver of area effects. Ewers et al. (2007) have previously suggested that edge effects could underlie many ecological patterns that are superficially related to patch area, and later showed in a spatially-explicit model that 
edge effects, in combination with patch shape, can generate strong areal gradients in the size and density of beetle species' populations (Ewers \& Didham, 2007). In a complementary meta-analysis, Fletcher et al. (2007) suggested that it is common for ecological studies to confound edge and area effects, and that there is considerable evidence to support the contention that edge effects are an important determinant of area effects for many taxa. Our study is one of the few that have purposefully distinguished between edge and area effects, and our results lend empirical support to the hypothesis that, in landscape ecology, the effects of patch area on communities may frequently be mediated through edge effects.

In conclusion, we found a degraded bird community in a fragmented landscape of Atlantic secondary forest when compared to a nearby continuous primary forest. Nevertheless, edge effects in patches of secondary forest were just as strong as those reported for fragments and areas of continuous Amazonian primary forest, showing that at least some of the ecological patterns described for primary forests are essentially alike in secondary forests. We also provided evidence to suggest that edge-related gradients in bird community composition are not only quantitatively similar to arearelated gradients, but may in fact be the principal driver of the widely known pattern of area effects on communities in fragmented landscapes. These results are relevant not only for elucidating the theoretical underpinnings of the species-area relationship in island biogeography and landscape ecology (Laurance, 2008), but also by having particular application in the conservation and management of endangered tropical forest areas, such as the Atlantic forest.

\section{Acknowledgements}

We thank all those who participated in this study, including the 33 people who assisted with the field work. In particular, we would like to thank J.R. Mello Jr. and C. Parruco, 
without who this work would not have been possible. R. Didham, R. Fletcher, W. Laurance and R. Pardini provided helpful comments on this manuscript. Research support was provided by CNPq, CAPES, Instituto de Biociências/USP, Imperial College London, SELVA and BIOCAPSP.

\section{References}

Anjos, L. \& Bocon, R. (1999) Bird communities in natural forest patches in southern Brazil. Wilson Bulletin, 111, 397-414.

Barlow, J., Gardner, T. A., Araujo, I. S., Avila-Pires, T. C., Bonaldo, A. B., Costa, J. E., Esposito, M. C., Ferreira, L. V., Hawes, J., Hernandez, M. I. M., Hoogmoed, M. S., Leite, R. N., Lo-Man-Hung, N. F., Malcolm, J. R., Martins, M. B., Mestre, L. A. M., Miranda-Santos, R., Nunes-Gutjahr, A. L., Overal, W. L., Parry, L., Peters, S. L., Ribeiro-Junior, M. A., da Silva, M. N. F., Silva Motta, C., \& Peres, C. A. (2007) Quantifying the biodiversity value of tropical primary, secondary, and plantation forests. Proceedings of the National Academy of Sciences, 104, 18555-18560.

Cincotta, R. P., Wisnewski, J., \& Engelman, R. (2000) Human population in the biodiversity hotspots. Nature, 404, 990-992.

Develey, P. F. (2004) Efeitos da fragmentação e do estado de conservação da floresta na diversidade de aves de Mata Atlântica. PhD Thesis. Universidade de São Paulo, São Paulo.

Didham, R. K., Hammond, P. M., Lawton, J. H., Eggleton, P., \& Stork, N. E. (1998) Beetle species responses to tropical forest fragmentation. Ecological Monographs, 68, 295-323.

Ewers, R. M. \& Didham, R. K. (2006) Confounding factors in the detection of species responses to habitat fragmentation. Biological Reviews, 81, 117-142.

Ewers, R. M. \& Didham, R. K. (2007) The effect of fragment shape and species' sensitivity to habitat edges on animal population size. Conservation Biology, 21, 926-936.

Ewers, R. M., Thorpe, S., \& Didham, R. K. (2007) Synergistic interactions between edge and area effects in a heavily fragmented landscape. Ecology, 88, 96-106.

Faith, D. P., Minchin, P. R., \& Belbin, L. (1987) Compositional dissimilarity as a robust measure of ecological distance. Vegetatio, 69, 57-68.

Ferraz, G., Russell, G. J., Stouffer, P. C., Bierregaard, R. O., Pimm, S. L., \& Lovejoy, T. E. (2003) Rates of species loss from Amazonian forest fragments. Proceedings of the National Academy of Sciences of the United States of America, 100, 1406914073. 
Fletcher, R. J., Ries, L., Battin, J., \& Chalfoun, A. D. (2007) The role of habitat area and edge in fragmented landscapes: definitively distinct or inevitably intertwined? Canadian Journal of Zoology, 85, 1017-1030.

Gardner, T. A., Barlow, J., Parry, L. W., \& Peres, C. A. (2007) Predicting the uncertain future of tropical forest species in a data vacuum. Biotropica, 39, 25-30.

Haila, Y. (2002) A conceptual genealogy of fragmentation research: from island biogeography to landscape ecology. Ecological Applications, 12, 321-334.

Harper, K. A., MacDonald, S. E., Burton, P. J., Chen, J., Brosofske, K. D., Saunders, S. C., Euskirchen, E. S., Roberts, D., Jaiteh, M. S., \& Esseen, P. A. (2005) Edge influence on forest structure and composition in fragmented landscapes. Conservation Biology, 19, 768-782.

Harris, G. M. \& Pimm, S. L. (2004) Bird species' tolerance of secondary forest habitats and its effects on extinction. Conservation Biology, 18, 1607-1616.

Hasui, E. (2003) Influência da variação fisionômica da vegetação sobre a composição de aves frugívoras da Mata Atlântica. PhD Thesis. Universidade de Campinas, Campinas.

Imbeau, L., Drapeau, P., \& Mönkkönen, M. (2003) Are forest birds categorised as "edge species" strictly associated with edges? Ecography, 26, 514-520.

Laurance, S. G. (2004) Responses of understory rain forest birds to road edges in central Amazonia. Ecological Applications, 14, 1344-1357.

Laurance, S. G., Stouffer, P. C., \& Laurance, W. F. (2004) Effects of road clearings on movement patterns of understory rainforest birds in Central Amazonia. Conservation Biology, 18, 1099-1109.

Laurance, W. F. (2008) Theory meets reality: how habitat fragmentation research has transcended island biogeographic theory. Biological Conservation, 141, 1731-1744.

Laurance, W. F. (2007) Have we overstated the tropical biodiversity crisis? Trends in Ecology \& Evolution, 22, 65-70.

Laurance, W. F., Nascimento, H. E. M., Laurance, S. G., Andrade, A., Ribeiro, J. E. L. S., Giraldo, J. P., Lovejoy, T. E., Condit, R., Chave, J., Harms, K. E., \& D'Angelo, S. (2006) Rapid decay of tree-community composition in Amazonian forest fragments. Proceedings of the National Academy of Sciences, 103, 19010-19014.

Levey, D. J. (1988) Tropical wet forest treefall gaps and distributions of understory birds and plants. Ecology, 69, 1076-1089.

Lindell, C. A., Riffell, S. K., Kaiser, S. A., Battin, A. L., Smith, M. L., \& Sisk, T. D. (2007) Edge responses of tropical and temperate birds. Wilson Journal of Ornithology, 119, 205-220.

MacArthur, R. H. \& Wilson, E. O. (1967) The theory of island biogeography. Princeton University Press, Princeton. 
Malcolm, J. R. (1994) Edge effects of central Amazonian forest fragments. Ecology, 75, 2438-2445.

Manne, L. L., Brooks, T. M., \& Pimm, S. L. (1999) Relative risk of extinction of passerine birds on continents and islands. Nature, 399, 258-261.

Metzger, J. P., Martensen, A. C., Dixo, M., Bernacci, L. C., Ribeiro, M. C., Teixeira, A. M. G., \& Pardini, R. (2009) Time-lag in biological responses to landscape changes in a highly dynamic Atlantic forest region. Biological Conservation, 142, 1166-1177.

Millennium Ecosystem Assessment (2005) Ecosystems and Human Well-Being: Synthesis. Island Press, Washington, DC.

Moore, R. P., Robinson, W. D., Lovette, I. J., \& Robinson, T. R. (2008) Experimental evidence for extreme dispersal limitation in tropical forest birds. Ecology Letters, 11.

Oliveira, M. A., Grillo, A. S., \& Tabarelli, M. (2004) Forest edge in the Brazilian Atlantic forest: drastic changes in tree species assemblages. Oryx, 38, 389-394.

Pardini, R. (2004) Effects of forest fragmentation on small mammals in an Atlantic Forest landscape. Biodiversity and Conservation, 13, 2567-2586.

Pardini, R., de Souza, S. M., Braga-Neto, R., \& Metzger, J. P. (2005) The role of forest structure, fragment size and corridors in maintaining small mammal abundance and diversity in an Atlantic forest landscape. Biological Conservation, 124, 253-266.

Restrepo, C. \& Gomez, N. (1998) Responses of understory birds to anthropogenic edges in a Neotropical montane forest. Ecological Applications, 8, 170-183.

Ribeiro, M. C., Metzger, J. P., Martensen, A. C., Ponzoni, F. J., \& Hirota, M. M. (2009) The Brazilian Atlantic Forest: How much is left, and how is the remaining forest distributed? Implications for conservation. Biological Conservation, 142, 1141-1153.

Riitters, K., Wickham, J., O'Neill, R. V., Jones, B., \& Smith, E. (2000) Global-scale patterns of forest fragmentation. Conservation Ecology, 4, 3.

Sekercioglu, C. H., Ehrlich, P. R., Daily, G., Aygen, D., Goehring, D., \& Sandi, R. F. (2002) Disappearance of insectivorous birds from tropical forest fragments. Proceedings of the National Academy of Sciences U.S.A., 99, 263-267.

Stotz, D., Fitzpatrick, J. W., Parker III, T. A., \& Moskovits, D. K. (1996) Neotropical birds: ecology and conservation. University of Chicago Press, Chicago.

Stouffer, P. C. \& Bierregaard, R. O. Jr. (1995a) Effects of forest fragmentation on understory hummingbirds in Amazonian Brazil. Conservation Biology, 9, 10851094.

Stouffer, P. C. \& Bierregaard, R. O. Jr. (1995b) Use of Amazonian forest fragments by understory insectivorous birds. Ecology, 76, 2429-2445. 
Teixeira, A. M., Soares-Filho, B. S., Freitas, S. R., \& Metzger, J. P. (2009) Modeling landscape dynamics in an Atlantic Rainforest region: Implications for conservation. Forest Ecology and Management, 257, 1219-1230.

Villard, M.-A. (1998) On Forest-interior Species, Edge Avoidance, Area Sensitivity and Dogmas in Avian Conservation. Auk, 115, 801-805.

Wright, S. J. (2005) Tropical forests in a changing environment. Trends in Ecology \& Evolution, 20, 553-560.

Wright, S. J. \& Muller-Landau, H. C. (2006) The future of tropical forest species. Biotropica, 38, 287-301. 
Table 1. Effects of habitat edges on vegetation structure. Results are for Wilcoxon paired tests $(N=8)$ for the five measures of vegetation structure. Positive $Z$ values indicate higher values in patch interiors, negative values indicate higher values at patch edges. Vegetation stratification is represented as the first axis of a PCA performed on the profiles of foliage height distribution for each site.

\begin{tabular}{|c|c|c|c|c|c|c|}
\hline & \multicolumn{2}{|c|}{ Patch edge } & \multicolumn{2}{|c|}{ Patch interior } & & \\
\hline Vegetation Structure & Median & $\begin{array}{l}\text { Inter- } \\
\text { quartile } \\
\text { range }\end{array}$ & Median & $\begin{array}{l}\text { Inter- } \\
\text { quartile } \\
\text { range }\end{array}$ & $Z$ & $P$ \\
\hline Coefficient of variation of $\mathrm{DBH}$ & 0.67 & 0.18 & 0.64 & 0.10 & -0.56 & 0.575 \\
\hline Mean of DBH & 34.19 & 1.65 & 33.33 & 2.88 & 0.42 & 0.674 \\
\hline Number of trees & 105 & 19.25 & 96 & 22.55 & 0.14 & 0.889 \\
\hline Number of bromeliads ( $\log 2)$ & 0.60 & 0.78 & 0.92 & 0.57 & 1.35 & 0.176 \\
\hline Vegetation stratification & - & & - & - & -0.28 & 0.779 \\
\hline
\end{tabular}


Table 2. Effects of habitat edges on bird communities. Results are for generalized linear mixed model with Poisson errors for nested count data $(N=8)$ on the species richness and abundance of birds and functional guilds. Positive $Z$ values indicate higher values in patch interiors, negative values indicate higher values at patch edges; * indicates significant results at $P<0.05$.

\begin{tabular}{lrrrr}
\hline & \multicolumn{2}{c}{ Abundance } & \multicolumn{2}{c}{ Richness } \\
\hline Assemblages & $Z$ & $P$ & \multicolumn{1}{c}{$Z$} & $P$ \\
\hline Total bird assemblage & 3.09 & $0.002 *$ & 0.45 & 0.652 \\
Frugivorous birds & 1.41 & 0.160 & 0.08 & 0.930 \\
Insectivorous birds & 5.04 & $<0.001 *$ & 0.90 & 0.364 \\
Hummingbirds & -4.30 & $<0.001 *$ & -1.74 & 0.080 \\
Sensitive species & 5.92 & $<0.001 *$ & 2.61 & $0.008 *$ \\
Generalist species & -1.32 & 0.187 & -1.36 & 0.171 \\
\hline
\end{tabular}




\section{Figure Legends}

Figure 1. Ordination plot of HMDS axes showing gradients in bird composition among 31 sites in Brazilian Atlantic forest patches. Filled and open squares represent interior and edge sites respectively and symbols are scaled to represent patch size. Letters represent the centroids for different site categories: $\mathrm{C}=$ control sites, $\mathrm{E}=$ edge, $\mathrm{L}=$ large patch interiors, $\mathrm{S}=$ small patches.

Figure 2. Dissimilarity of bird community composition between sites located at patch edges and the centroids for different site categories. Euclidean distance is measured from Fig. 1 and represents the distance between edge sites (open squares) and the “edge", "large patch interior" and "small patch" centroids and to the interior sites located in the same patch. Edge communities were significantly more different to large patch communities than they were to (1) adjacent sites located in the interior of the same patch; (2) other edge sites; or (3) small patch communities. Thick lines represent the median, boxes represent the interquartile range and whiskers represent minimum and maximum values. Asterisk depicts significant difference among levels.

Figure 3. Difference in bird species composition between paired sites located at the edge and interior of large and medium-sized patches, regressed against log10- transformed patch size. Species composition was calculated from the first two axes of an HMDS ordination (Fig. 1), and the difference between communities was the Euclidean distance between the location of the paired edge and interior sites in ordination space.

Figure 4. Decay of compositional similarities in the bird community between the control centroid and the different sites regressed against patch size as a (a) continuous and (b) 
categorical variable. In (a), triangles represent patches where only one site was sampled, open squares represent the edge sites in medium and large patches and filled squares represent the interior sites in these same patches. The dashed line is fitted through the data from small patches and the edge of medium and large patches, and was not statistically significant. The solid line corresponds to the least-squares line fitted through the data from small patches and the interior sites of medium and large patches $(P<0.001)$. In (b), sites are classified as belonging to either the interior of small (3-5 ha) patches, or the edge and interior of medium (8-30 ha) and large (90-150 ha) patches. Control sites are presented for comparison and to show within-control variability, but were not tested in the model. Thick lines represent the median, boxes represent the interquartile range and whiskers represent minimum and maximum values. Asterisks depict significant difference among levels. The decay in compositional similarities was significantly smaller at the interior of large patches than at any other patch size class, while the communities at the edges of large and medium patches were similar to the one found at small patches.

Figure 5. Consistency of species responses to forest edges and patch size. Edge effects for individual species are represented by the Z-values from a generalized linear mixed model with Poisson errors for nested data of abundance in edge and interior, with negative values representing an increase in abundance at patch edges. Area effects are represented by the $\beta$ - values resulting from generalized linear models with Poisson errors, in which negative values represent species that increased in abundance in smaller patches. 
Figure 1

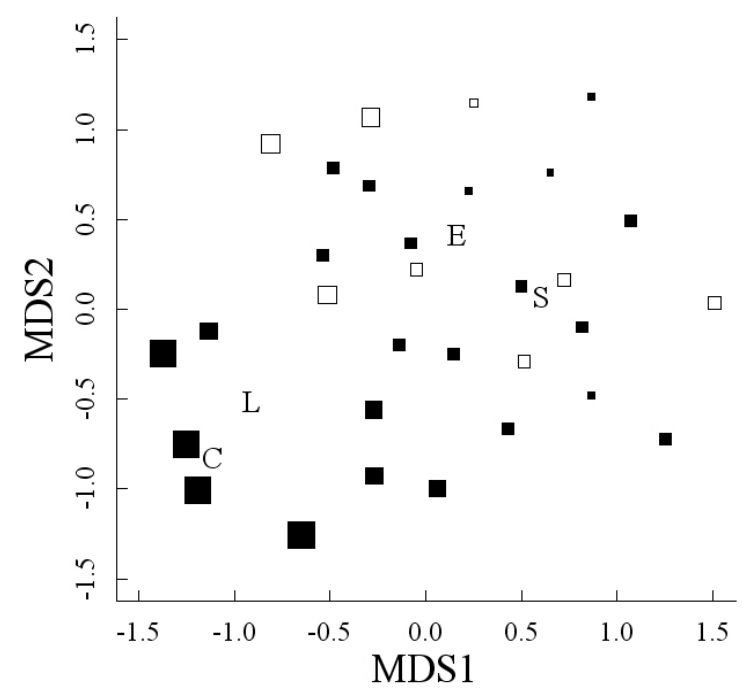


Figure 2

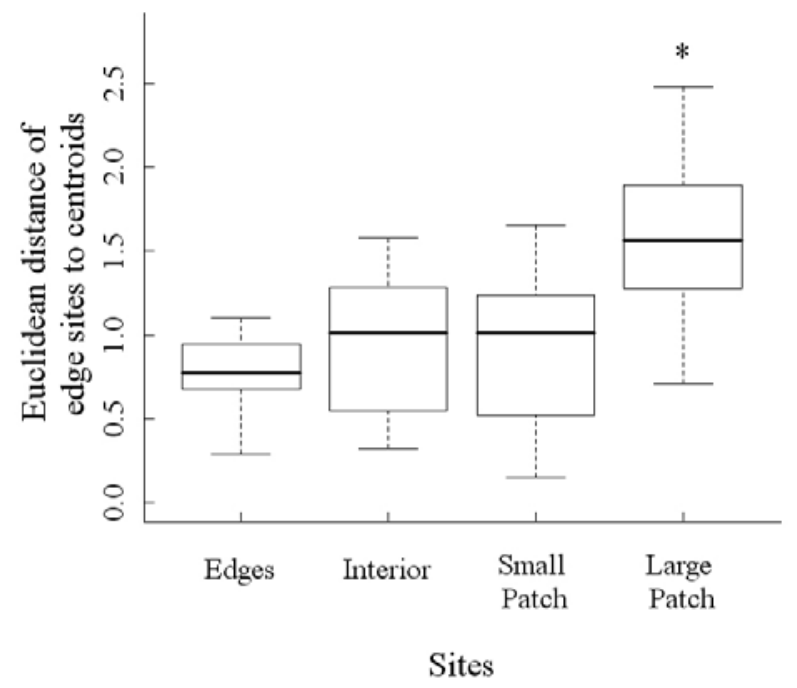


Figure 3

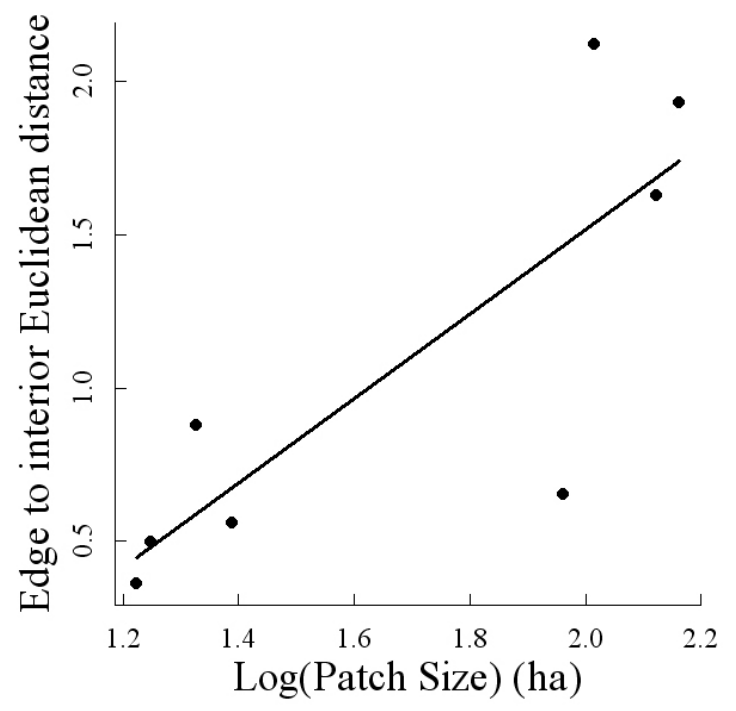


Figure 4

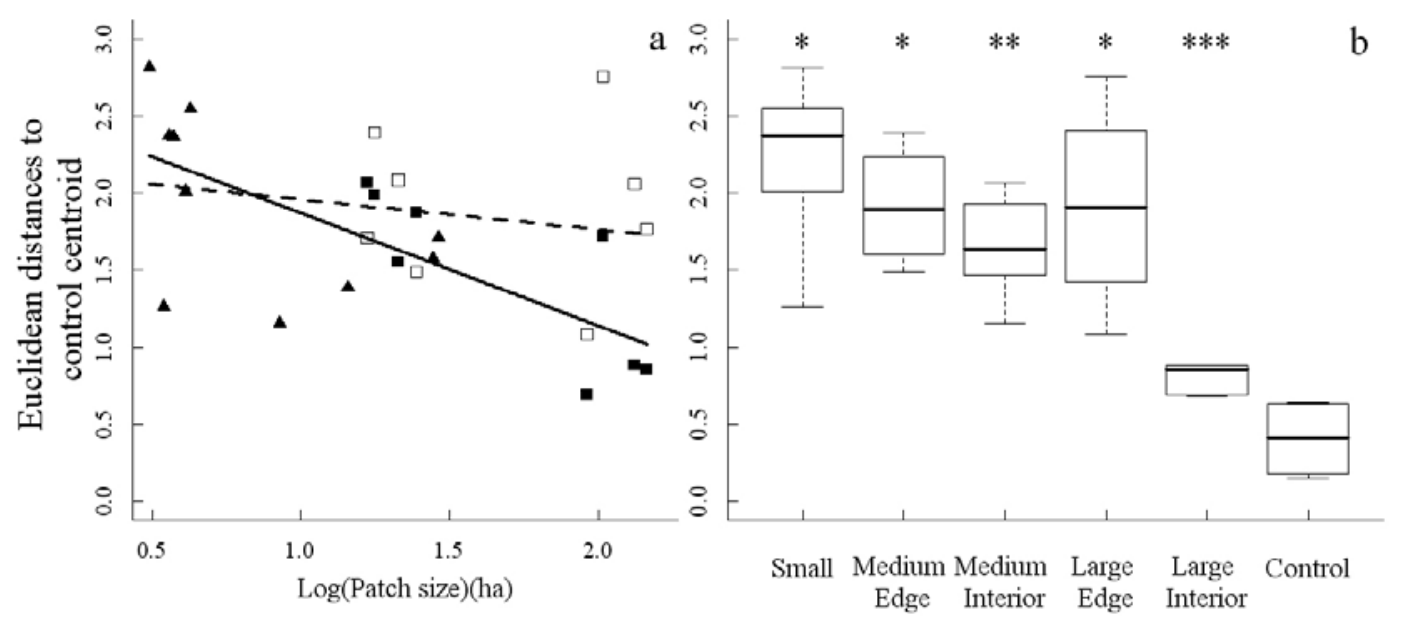


Figure 5

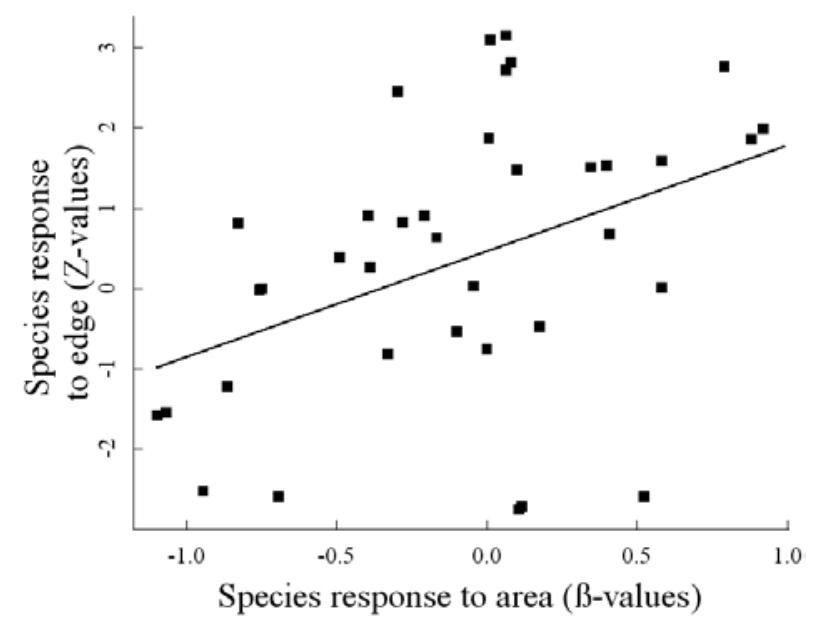




\section{Capítulo 4}

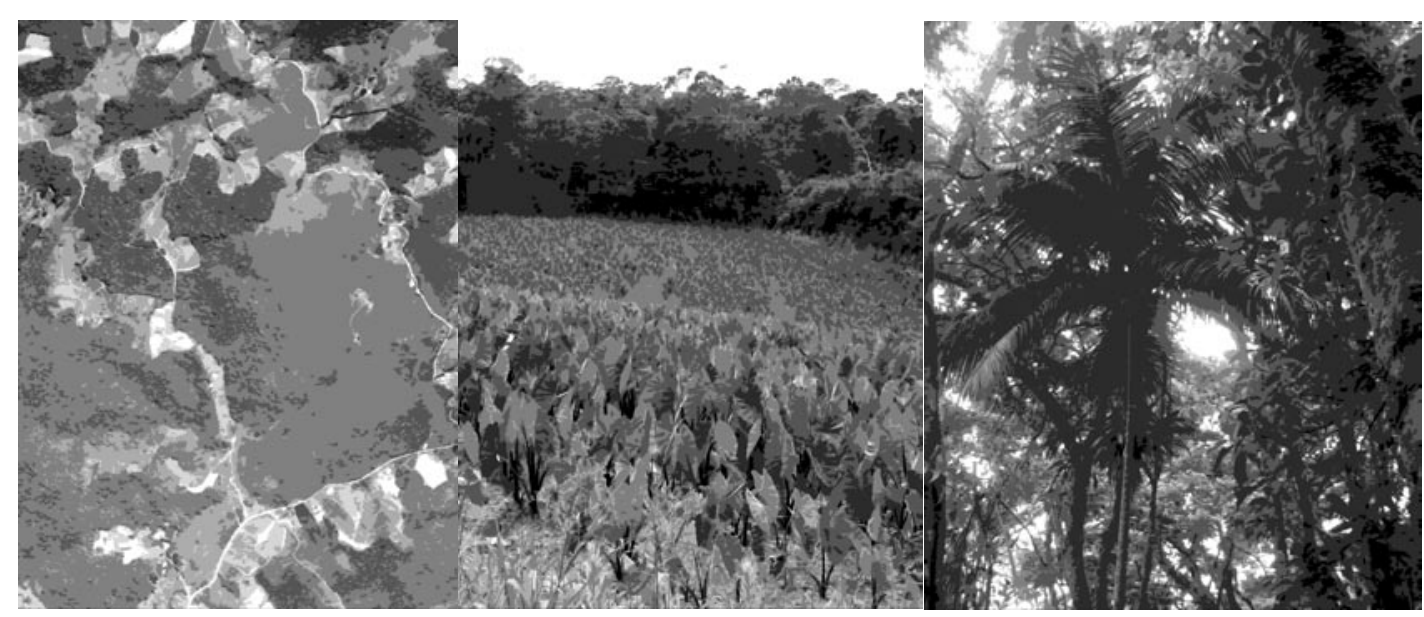


Capítulo 4

Disentangling the confounded effects of habitat loss, configuration and quality on understorey bird communities of the Atlantic Forest

Cristina BANKS-LEITE, Robert M. EWERS \& Jean-Paul METZGER 


\section{Resumo}

Diversos estudos procuram identificar a importância relativa de fatores responsáveis pelas variações em populações e comunidades presentes em paisagens fragmentadas, como a importância de perda de cobertura florestal, configuração de fragmentos florestais e qualidade do habitat. No entanto, a natureza altamente correlacionada destes fatores complica a análise dos dados, pois técnicas estatísticas comuns levam a resultados simplistas e bastante enviesados. Assim, neste estudo, nós usamos duas técnicas estatísticas, partição de variância e modelos de equações estruturais, que exploram explicitamente a correlação entre variáveis para estimar a correlação entre a perda de cobertura florestal, configuração de fragmentos florestais e qualidade do habitat, assim como avaliar a relativa importância destes fatores como variáveis preditoras da comunidade de aves. Nós estudamos uma paisagem fragmentada de Floresta Atlântica, na qual a comunidade de aves foi amostrada com um esforço fixo de 680 horas-rede em cada um dos 23 sítios amostrados, o que resultou em aproximadamente 2,600 capturas em um total de 15,000 horas-rede. Os resultados das regressões simples e múltiplas mostraram que as mudanças na cobertura florestal, configuração de fragmentos florestais e qualidade do habitat foram responsáveis por explicar uma grande proporção na variação da comunidade de aves, mas os resultados da partição de variância mostraram que a correlação entre os fatores era tão alta que a contribuição única de cada um era insignificante. Os resultados dos modelos de equação estrutural mostraram que todas as variáveis eram importantes, apesar de nãoindependentes, preditoras da riqueza de espécies, abundância e composição da comunidade, e também que a importância relativa de cada fator dependia do atributo e da comunidade analisada. Nossos resultados corroboram a noção de que as espécies são afetadas por características do habitat em múltiplas escalas simultaneamente e desafiam as sugestões de que perda de habitat é mais importante que configuração dos remanescentes. 


\begin{abstract}
Numerous studies attempt to identify a single dominant factor, such as habitat loss, configuration or quality, that underlies the responses of species to habitat fragmentation. Yet the heavily intercorrelated nature of these factors complicates analyses, and standard statistical approaches lead to oversimplified and biased results. In this study, we used variation partitioning and structural equation modelling (SEM) to estimate the relative importance of changes in forest cover, patch configuration and habitat quality as predictors of spatial patterns of variation in bird community structure in the fragmented Atlantic forest in Brazil. Mist-net sampling with a constant effort of 680 net-hours at each of 23 sites resulted in almost 2,600 captures from 15,000 net-hours. Simple and multiple regressions showed that changes in forest cover, patch configuration and habitat quality explained a large proportion of the variation in the bird community, but the results from variation partitioning showed that the intercorrelation among factors was so high that the unique contribution of each was negligible and non-significant. SEM, meanwhile, showed that all variables were important, albeit non-independent, predictors of species richness, abundance and composition, and that the relative importance of each factor differed depending on the community attribute and assemblage analysed. Our results corroborate the notion that species simultaneously respond to habitat characteristics at multiple scales and challenge the growing notion that habitat cover is more important than configuration.
\end{abstract}

Key-words: habitat fragmentation, structural equation modeling, understory birds, variation partitioning, scale

\title{
Running head: DISENTANGLING THE EFFECTS OF HABITAT
}

FRAGMENTATION 


\section{1 - Introduction}

As an area is deforested, the habitat is simultaneously lost, fragmented and altered in quality due to changes in vegetation structure (Fahrig, 2003; Gardner et al., 2009). These three processes occur simultaneously and are so tightly correlated in space that the task of separating them in the field is almost insurmountable. Thus, identifying the relative influence of habitat loss, fragmentation and quality suffers from large methodological difficulties. Nonetheless, the question has tremendous practical importance, as conservations strategies directed to mitigate one of these factors might not be efficient to reduce the impacts of the others (Gardner et al., 2009).

There is an extended literature on the importance of habitat loss, configuration and quality for species of various taxa. For instance, numerous studies have shown that habitat quality, represented by changes in vegetation structure and composition, has a strong influence on taxa ranging from lichens to birds (Johansson \& Ehrlen, 2003; Coreau \& Martin, 2007; Barlow et al., 2007). The same can also be said about the influence of patch size and edge effects (Villard et al., 1999; Ewers et al., 2007; Ferraz et al., 2007; Ewers \& Didham, 2008), and for the amount of forest cover in the landscape (Trzcinski et al., 1999; Saab, 1999; Fahrig, 2002; Fleishman \& Mac Nally, 2007). But vegetation structure and composition are highly influenced by patch size and edge effects (Laurance et al., 2006; Santos et al., 2008), and the configuration of a landscape is strongly correlated with the amount of forest cover (Andrén, 1994; Fahrig, 2003). The variables described also above represent three distinct hierarchical scales; the plot (or site), patch and landscape scale representing changes in vegetation structure and composition, patch size and distance to edge, and forest cover respectively (Cushman \& McGarigal, 2004). Thus, these factors are nested in space and causally associated, so it is not surprising that they are highly correlated in nature. 
High collinearity among variables poses a strong bias on standard statistical analyses. In multiple regressions, the presence of collinear variables has a profound effect on the slope estimates and standard error of the variables, which are the basis from which p-values are calculated (Legendre \& Legendre, 1998; Graham, 2003). In such a context, stepwise procedures such as backward deletion of non-significant variables that are otherwise recommended (Crawley, 2007), can give misleading results as the decision to delete the least significant variable may not generate the best subset of variables in the model (Petraitis et al., 1996). To avoid this problem, many researchers choose to omit correlated variables by including only the most important explanatory variable (e.g. largest $R^{2}$ ) in the model, but this approach does not allow for testing the relative importance of variables (Legendre \& Legendre, 1998). One of the most popular alternative procedures has been the use of residual regressions, in which one variable is assumed to be functionally more important than the other (Graham, 2003). Here, the less important variable is regressed against the more important one and the residuals from this regression will be used as the predictor representing the less important variable. However, a major drawback of this procedure is that the shared contribution of the two variables is attributed to just one of the them, and if the correlation between the two variables is large then it is most likely that the variable considered a priori to be less important will never show a strong, unique effect (Koper et al., 2007).

More recently, some studies have overcome these problems by using techniques that explicitly account for, rather than ignore, the intercorrelation “problem”. With basic equations of addition and subtraction, variation partitioning is the simplest and easiest way to measure the amount of shared and unique contribution of correlated variables (Legendre \& Legendre, 1998; Cushman \& McGarigal, 2002). Another promising approach is structural equation modelling (SEM), which is similar to path analysis but 
overcomes many of the drawbacks (Petraitis et al., 1996) by incorporating latent variables which account for the correlation among variables (Graham, 2003). Interestingly, most studies investigating the relative importance of habitat cover, configuration and quality that have accounted for the covariance among variables have reached the conclusion that multiple factors drive biodiversity changes (Saab, 1999; Cushman \& McGarigal, 2004; Lawler \& Edwards, 2006; Battin \& Lawler, 2006; Coreau \& Martin, 2007). These results stand in contrast to studies that have used residual regressions and have reported that only one factor was important (van Dorp \& Opdam, 1987; Trzcinski et al., 1999; Fahrig, 2003).

In this study, we addressed the question of how a tropical understory bird community responds to highly inter-correlated variation in forest cover, patch configuration and habitat quality. We used two statistical approaches that explicitly account for the correlation among variables to explore this question: (1) we use variation partitioning as a tool to assess the unique and shared contribution of the three variables, and (2) we compare the variance partitioning results with those from a SEM, in which we search for the best set of predictors for explaining patterns in the understory bird community. We show that standard statistical techniques give an oversimplified and biased impression of how habitat loss and fragmentation alter bird communities, and describe how those communities are simultaneously structured by landscape, patch and local characteristics.

\section{2 - Methods}

Study area

The study was conducted in the Atlantic Plateau of the State of São Paulo, Brazil. The original vegetation in the area is classified as lower montane Atlantic forest, the mean 
altitude is $870 \mathrm{~m}$ above sea level, the mean annual temperature is $19^{\circ} \mathrm{C}$ and annual rainfall is $1,808 \mathrm{~mm}$ (www.cpa.unicamp.br). Part of the sampling was conducted in a 10,000 ha fragmented landscape $\left(23^{\circ} 50^{\prime} \mathrm{S}, 47^{\circ} 20^{\prime} \mathrm{W}\right)$, which has $50 \%$ native forest cover in various successional stages (from 20 to over 100 years), $38 \%$ cropland and the remaining is mainly comprised of wetlands, Eucalyptus spp. Plantations and other land uses. We also sampled an adjacent forested area, the State Park of Jurupará, which is located just five km from the fragmented landscape. It has historically been subjected to selective logging of hardwood tress and now consists of a highly advanced successional stage, with a species composition approaching that of primary forests.

We sampled a total of four sites in the continuous forest and 19 patches in the fragmented landscape. Forest patches were selected to reflect the natural variation in patch size and connectivity present in the fragmented landscape. Thus we selected seven small patches ranging from 3 to 5 ha, eight medium-sized patches from 8 to 30 ha and four large patches of 90 to 150 ha. A stratified selection procedure was performed so that in each size class, half of the patches had low values of the proximity index (at the patch level) and half had high proximity levels (McGarigal \& Marks, 1995). The fragments were composed of a mosaic of different forest successional stages, with a predominance of medium to advanced stages ( $\sim 30$ years or older). The four control sites in Jurupará State Park were separated by at least $1.5 \mathrm{~km}$, were located at least $400 \mathrm{~m}$ from the nearest forest edge, and situated in two large blocks of forest of approximately 6,700 ha and 14,800 ha each.

\section{Sampling the bird community}

Birds were sampled using 10 mist nets (12 m length, $2.5 \mathrm{~m}$ high, $31 \mathrm{~mm}$ mesh) positioned in a single line that was as straight as possible and followed the slope 
contour. We sampled each of the 23 sites in four surveys of two consecutive days. In the first day, nets were opened at sunrise and closed at sunset; on the second day nets were opened at sunrise and closed six hours later. Each site was surveyed twice in the dry season (austral winter of 2005 and 2006) and twice in the wet season (summer of 2005/2006 and 2006/2007), until we reached a total of 680 net-hours per site. Nets were checked every hour and closed whenever there was a heavy rain. All captured birds were marked with a numbered aluminum band provided by the Center of Research for Conservation of Wild Birds (CEMAVE - IBAMA) and released in the vicinity. All birds were identified to species in the field and later categorized into two habitat specialization categories, sensitive and generalist species, that divided bird species according to their published responses to human disturbances (Stotz et al., 1996).

\section{Measuring forest cover, patch configuration and habitat quality}

At all 23 sites, we assessed habitat quality by measuring vegetation structure in a $2.5 \times$ $120 \mathrm{~m}$ plot along a 120-m mist net line. Inside this plot we measured the diameter at breast height of all trees (above $5 \mathrm{~cm} \mathrm{DBH}$ ) and the number of bromeliads in bloom at up to four meters height above ground. We also quantified understory vegetation stratification with 42 foliage height profiles in each plot. Every $6 \mathrm{~m}$ along the plot, we sampled two points (one on each side of the path) with a $2.5 \mathrm{~m}$ vertical pole and recorded the $50-\mathrm{cm}$ height intervals which had vegetation touching the pole. Changes in habitat quality were quantified as the mean and coefficient of variation of $\mathrm{DBH}$, the number of trees and the number of bromeliads inside each plot, and the profiles of foliage height distribution at each site.

To measure forest cover and patch configuration, we classified a Spot 5 image from 2005 into forest and non-forest with a 10 m resolution. Patch and landscape 
metrics were calculated using Fragstats 3.3 (McGarigal \& Marks, 1995). Patch level metrics related to habitat configuration were: patch size, distance from the sampling point to the nearest edge and the perimeter to area ratio of the patch. Landscape variables related to habitat cover were the amount of forest cover in circles of radii at every $100 \mathrm{~m}$ interval from 300 to $1300 \mathrm{~m}$ around the sampling point (radii selected following Boscolo (2007).

\section{Statistical analyses}

The relative structure of bird assemblages were quantified as species richness, capture rate (hereafter referred to as abundance, as we excluded all recaptures within the same site from the analysis), and community composition, which was measured as a single axis of a Principal Coordinate Analysis (PCoA), using a Bray-Curtis dissimilarity index on untransformed abundance data.

We first performed a Mantel test with 1000 permutations to check for spatial autocorrelation among sites in the fragmented landscape in terms of bird community composition. At this step, we did not analyse all 23 sites because the control sites were located in a different part of the study area, and their inclusion would bias the analysis of spatial structure by mostly evaluating if the community composition at the control sites was different to the one found in the fragmented landscape. We also constructed a Pearson correlation matrix to examine the univariate relationships between the response and explanatory variables, and excluded explanatory variables that did not have significant correlations with any of the bird assemblages. We then performed a separate Principal Components Analysis (PCA) on each of the three sets of variables representing changes in forest cover, patch configuration and habitat quality to reduce these variables into a small number of axes representing the three major factors. Simple 
and multiple linear regressions were used to investigate how the richness and abundance of sensitive species, generalist species and the total community, as well as community composition, were influenced by each of these factors. We used variation partitioning (Legendre \& Legendre, 1998) to assess the unique and shared contribution of each factor to the models explaining patterns of variation in the bird community. The unique contribution of each factor to each of the bird community models was tested with a residual regression.

For the structural equation models, we created a structure in which the response variable (species abundance, richness, or composition) was directly affected by habitat cover, configuration and quality, which were in turn caused by a single latent variable (i.e. an unmeasured variable calculated using factor analysis), which we term “Anthropogenic disturbance” (Fig. 1a). The predicted covariances between the observed variables in the model are functions of the paths linking them (both directly and indirectly), thus with the use of SEM it is possible to obtain unbiased estimates of the predicted covariance matrix and, therefore, of the asymptotic probability of the model under the null hypothesis, which is tested with a $\chi^{2}$ test (Shipley, 2000). In other words, because all factors were caused by the same variable, it was implicit in the model that they should also be correlated among each other; thus, the SEM procedure translates this model structure into more accurate estimates of slopes, $p$-values and the goodness of fit of the model (Shipley, 2000). Inspection of the data showed that this was the only model structure possible (Fig. 1a), as there were no significant paths linking environmental variables among each other. Also, one of the two habitat quality axes was not significantly correlated with the remaining variables, therefore we used it in the model as an exogenous variable, i.e. not caused by any other variable. We performed backward elimination to remove the variables that contributed the least to explaining the 
response variable to reach the most parsimonious model in which all variables were significant at $P \leq 0.05$. The fit of each nested model in the backward deletion procedure was compared using AIC values (Burnham \& Andersen, 1998). All SEM analyses were performed in Amos 5 while the remaining analyses were performed in $R$ v2.5.1 ( $\mathrm{R}$ Development Core Team, 2007).

\section{3 - Results}

In total we captured 2166 individuals belonging to 109 species. The three most abundant species were Chiroxiphia caudata (134 individuals), Trichothraupis melanops (126 individuals) and Platyrinchus mystaceus (125 individuals), which are all strictly forest species. The bird community was typical of rich tropical areas with some abundant species (30 species with more than 30 individuals) but numerous rare species (73 species with less than 10 individuals). The first axis of the PCoA on bird community composition explained $17 \%$ of the variation in community composition and, because it was performed on an abundance data matrix, primarily reflected changes in abundance of the most frequently captured species.

A Mantel test showed that there was no spatial autocorrelation in species composition among sites in the fragmented landscape $(r=0.058, P=0.252)$. The first axis of the PCA on forest cover and patch configuration explained most of the variation (variation explained by the first PCA axis was $92.7 \%$ for habitat cover and $91 \%$ for patch configuration), and therefore we only used one axis; however, the PCA on vegetation structure variables explained just 33.5\% of the variation, so in subsequent analyses we also used the second axis which explained a further $15 \%$ of the variation.

The variables representing habitat cover and configuration were not only highly correlated within factors but also between factors $(r=0.92, P<0.001)$. The first axis of 
the habitat cover PCA was positively correlated to the amount of forest cover in the landscape, while the first axis of the patch configuration PCA was positively correlated with patch size and negatively with distance to the nearest edge. The first axis of the habitat quality PCA was not significantly correlated with the habitat cover and configuration axes and represented changes in foliage profiles, with low values representing high amounts of foliage in the stratum from 1 to $2.5 \mathrm{~m}$ above ground. The second habitat quality axis was correlated with habitat cover $(r=-0.56, P<0.01)$ and configuration $(r=-0.57, P<0.01)$ and represented changes in hardwood vegetation; low scores corresponded to a low density of mostly large trees, which is a forest structure consistent with old secondary growth vegetation.

The richness and abundance of all bird assemblages were strongly correlated with habitat cover, configuration and quality; full models including all factors had coefficients of determination varying from $R^{2}=0.44$ to 0.92 (Table 1). However, because of the high correlation among factors, the unique contribution of each factor explained just 3 to $6 \%$ of the variance in the response variable. There was no evidence that any factor had a consistently higher contribution to explaining the response variable (Table 1). Regression of residuals also showed that none of the unique contributions of the variables were significant ( $P>0.05$ in all cases). In fact, most of the influence of each variable was in their shared contribution, i.e. the correlation among them, and in some cases, such as for the species richness and composition of the total community, the influence of some variables was fully subsumed within that of another variable (Fig. 2).

Although the variation partitioning showed that all factors were highly correlated and had non-significant unique effects, the AIC evidence ratio obtained from the SEM model selection was very similar for most models, with the only exception 
being the full model which had a poorer fit in all cases (Table 2). This indicates that the exclusion of one variable from the model yielded a considerable loss of information but that this loss was counterbalanced by an increase in model parsimony. However, the non-significant changes in $\chi^{2}$ throughout the backward deletion procedure showed that the exclusion of variables did not affect the goodness of fit of models, suggesting that such variables were unimportant to the model (Table 2).

Because SEMs can explicitly model the collinearity among variables, we were able to perform a backward deletion of non-significant variables with higher confidence and obtain the most parsimonious and best fitting model. The abundance of the total assemblage was positively correlated with patch size (patch configuration PCA1 standardised slope coefficient: $\beta=0.70$ ) while species richness was positively related to habitat cover (forest cover PCA1 $\beta=0.59$ ). Similarly, the abundance of sensitive species was positively affected by patch size (patch configuration PCA1 $\beta=0.82$ ) and the age of the vegetation (habitat quality PCA2 $\beta=-0.19$ ) while the richness of sensitive species was affected by forest cover and the age of the vegetation (habitat cover PCA1 $\beta=0.79$; habitat quality PCA2 $\beta=-0.23$ ). Both the abundance and species richness of generalist species were negatively related to just habitat cover (abundance: $\beta$ $=-0.82$; richness: $\beta=-0.82$ ). Finally, the change in composition was the only community attribute that was simultaneously related to habitat cover $(\beta=-0.53)$ and configuration $(\beta=-0.44)$ (Fig. 1b).

\section{4 - Discussion}

In this study we have shown that the correlation among environmental variables can be so large that any conventional approach for statistically analysing these data, such as multiple regressions, would be flawed. However, the concurrent use of variation 
partitioning and SEM allowed us to decouple the correlation among factors, extract the contribution from each factor and then select the best set of predictors for each response variable. For instance, simple and multiple regressions showed that variables representing habitat cover, configuration and quality explained a large proportion of the variation in species richness and abundance of the different assemblages, while the variation partitioning results showed that the effects of all factors were almost completely subsumed within the others (Table 1, Fig. 3). However, while the results from variation partitioning showed us the exact unique and shared contribution of environmental variables, it did not give us a clear-cut basis from which to choose the most parsimonious model to explain changes in the bird community. Thus, the approach of using variation partitioning in parallel with SEM proved to be advantageous, with the SEM allowing us to build a more complete model that showed how birds respond to their surroundings at multiple spatial scales.

The relative importance of forest cover, patch configuration and habitat quality has considerable theoretical and applied importance and has therefore been the aim of many studies (Fleishman et al., 2002; Fahrig, 2003; Cushman \& McGarigal, 2004; Martensen et al., 2008). However, the intrinsically confounded nature of these three variables forces researchers to control for this correlation. The first and most obvious option is to design the sampling in such a way that these variables are not correlated by choosing sites that vary in some metrics but not in others. This approach is relatively straightforward for modelling studies (Fahrig, 2002), but may be an impossible task in reality: vegetation structure, which we used as a measure of habitat quality, is profoundly influenced by the patch and landscape scales (Laurance et al., 2006), edge influence is confounded with patch size (Ewers et al., 2007; Fletcher et al., 2007) and mean patch size is non-linearly correlated with forest cover in the landscape (Andrén, 
1994). In our study, for instance, variables representing habitat cover, configuration and quality were all significantly intercorrelated with each other, with correlation coefficients ranging from 0.54 to 0.92 .

The second option to deal with the intercorrelated nature of predictor variables is to employ some of the available statistical approaches that deal with this correlation (Graham, 2003; Lawler \& Edwards, 2006; Battin \& Lawler, 2006), yet some approaches may not necessarily be suitable for this question. For instance, the use of residual regressions in which a hierarchical importance of variables is imposed by the researcher has led to a growing notion that habitat cover is more important that configuration (Trzcinski et al., 1999; Fahrig, 2003). However, a recent study by Koper et al. (2007) showed very clearly that the assumptions of the researcher when conducting a residual regression pre-determine the outcome of these analyses. In an analysis of songbird abundance in Canada, Koper et al. (2007) found that the variable added into the model first, be it habitat cover or configuration, was reported as a more influential variable than the variable analysed through regression of the residuals.

Our results, and those from others that have also used variation partitioning (Bennett et al., 2004; Coreau \& Martin, 2007), challenge the notion that habitat cover is more important than configuration. Our results also stand in contrast to those of Cushman \& McGarigal (2004) in which the plot level (e.g. vegetation structure and floristics) was found to be more important than the patch and landscape levels. Instead, the results from variation partitioning showed that the understory bird community composition and structure was equally affected by variation in habitat cover, configuration and quality. However, although no variable had an overall stronger effect, the relative influence of variables differed depending on the community attribute and assemblage being tested. For both the total understory community and for the 
assemblage of sensitive species, abundance tended to be more strongly linked with patch configuration while species richness tended to be more affected by habitat cover (Table 2). And while habitat quality was always selected as an important variable jointly with either forest cover or patch configuration for the assemblage of specialist species, the assemblage of generalist species was solely influenced by changes in forest cover.

An example serves as a useful method to clarify the advantages of the concurrent use of variation partitioning and SEM. For instance, simple regressions showed that patch configuration and landscape cover explained an impressive 87 and $88 \%$ of the variation in community composition, respectively. A simple correlation revealed that forest cover and patch configuration were highly correlated $(r=0.92)$. Variation partitioning showed that the unique effects of each variable were insignificant and that most of the forest cover and patch configuration effects was subsumed in their shared contribution (but also partly in their shared contribution with habitat quality). So, just with these results it would be impossible to achieve the best predictive model of the changes in community composition, because given the high correlation among variables, and insignificant unique contributions, one would have to choose the variable explaining the largest proportion of variation in the response variable, which in this was case forest cover. But, the SEM results showed instead that community composition is actually being affected by changes in both habitat cover and patch configuration simultaneously, therefore corroborating previous findings that communities respond, not to one, but to several scales at the same time (Cushman \& McGarigal, 2004).

In conclusion, we found that the combined use of variation partitioning and SEMs can provide a clear understanding of the processes causing variation in natural communities when explanatory variables are highly intercorrelated. Using both 
approaches, we found that the understorey bird community in the Atlantic forests of Brazil was equally affected by changes in forest cover in the landscape, patch configuration and habitat quality, but that the importance of these factors changed depending on the community attribute and assemblage analysed. Our results strongly suggest that simplistic analyses might provide a biased impression of how communities are structured in fragmented landscapes, and may ultimately offer misleading information to be used in the conservation of natural areas.

\section{Acknowledgements}

We thank all those who participated in this study, including the 33 people who assisted with the field work, particularly J.R. Mello Jr. and C. Parruco. R. Didham, V. Kapos, A.C. Martensen, P.I.K.L. Prado provided helpful comments on this manuscript and B. Shipley provided comments on the SEM model. Research support was provided by CNPq, CAPES, Instituto de Biociências/USP, Imperial College London, SELVA and BIOCAPSP.

\section{References}

Andrén, H. (1994) Effects of habitat fragmentation on birds and mammals in landscapes with different proportions of suitable habitat: a review. Oikos, 71, 355-366.

Barlow, J., Gardner, T. A., Araujo, I. S., Avila-Pires, T. C., Bonaldo, A. B., Costa, J. E., Esposito, M. C., Ferreira, L. V., Hawes, J., Hernandez, M. I. M., Hoogmoed, M. S., Leite, R. N., Lo-Man-Hung, N. F., Malcolm, J. R., Martins, M. B., Mestre, L. A. M., Miranda-Santos, R., Nunes-Gutjahr, A. L., Overal, W. L., Parry, L., Peters, S. L., Ribeiro-Junior, M. A., da Silva, M. N. F., Silva Motta, C., \& Peres, C. A. (2007) Quantifying the biodiversity value of tropical primary, secondary, and plantation forests. Proceedings of the National Academy of Sciences, 104, 18555-18560.

Battin, J. \& Lawler, J. J. (2006) Cross-scale correlations and the design and analysis of avian habitat selection studies. Condor, 108, 59-70. 
Bennett, A. F., Hinsley, S. A., Bellamy, P. E., Swetnam, R. D., \& Mac Nally, R. (2004) Do regional gradients in land-use influence richness, composition and turnover of bird assemblages in small woods? Biological Conservation, 119, 191-206.

Boscolo, D. (2007) Influência da estrutura da paisagem sobre a persistência de três espécies de aves em paisagens fragmentadas da Mata Atlântica. PhD Thesis. Universidade de São Paulo, São Paulo.

Burnham, K. P. \& Andersen, D. R. (1998) Model selection and multimodel inference: a practical information-theoretic approach. 2nd Ed. Springer, New York.

Coreau, A. \& Martin, J. L. (2007) Multi-scale study of bird species distribution and of their response to vegetation change: a Mediterranean example. Landscape Ecology, 22, 747-764.

Crawley, M. J. (2007) The R book. JohnWiley \& Sons, Ltd., Chichester.

Cushman, S. \& McGarigal, K. (2004) Hierarchical analysis of forest bird speciesenvironment relationships in the Oregon coast range. Ecological Applications, 14, 1090-1105.

Cushman, S. A. \& McGarigal, K. (2002) Hierarchical, Multi-scale decomposition of species-environment relationships. Landscape Ecology, 17, 637-646.

Ewers, R. M. \& Didham, R. K. (2008) Pervasive impact of large-scale edge effects on a beetle community. Proceedings of the National Academy of Sciences of the United States of America, 105, 5426-5429.

Ewers, R. M., Thorpe, S., \& Didham, R. K. (2007) Synergistic interactions between edge and area effects in a heavily fragmented landscape. Ecology, 88, 96-106.

Fahrig, L. (2002) Effect of habitat fragmentation on the extinction threshold: a synthesis. Ecological Applications, 12, 346-353.

Fahrig, L. (2003) Effects of habitat fragmentation on biodiversity. Annual Review of Ecology, Evolution and Systematics, 34, 487-515.

Ferraz, G., Nichols, J. D., Hines, J. E., Stouffer, P. C., Bierregaard, R. O., Jr., \& Lovejoy, T. E. (2007) A large-scale deforestation experiment: effects of patch area and isolation on Amazon birds. Science, 315, 238-241.

Fleishman, E. \& Mac Nally, R. (2007) Measuring the response of animals to contemporary drivers of fragmentation. Canadian Journal of Zoology, 85, 10801090 .

Fleishman, E., Ray, C., Sjogren-Gulve, P., Boggs, C. L., \& Murphy, D. D. (2002) Assessing the roles of patch quality, area, and isolation in predicting metapopulation dynamics. Conservation Biology, 16, 706-716.

Fletcher, R. J., Ries, L., Battin, J., \& Chalfoun, A. D. (2007) The role of habitat area and edge in fragmented landscapes: definitively distinct or inevitably intertwined? Canadian Journal of Zoology, 85, 1017-1030. 
Gardner, T. A., Barlow, J., Chazdon, R. L., Ewers, R. M., Harvey, C. A., Peres, C. A., \& Sodhi, N. S. (2009) Prospects for tropical forest biodiversity in a human-modified world. Ecology Letters, 12.

Graham, M. H. (2003) Confronting multicollinearity in ecological multiple regressions. Ecology, 84, 2809-2815.

Johansson, P. \& Ehrlen, J. (2003) Influence of habitat quantity, quality and isolation on the distribution and abundance of two epiphytic lichens. Journal of Ecology, 91, 213221.

Koper, N., Schmiegelow, F., \& Merrill, E. (2007) Residuals cannot distinguish between ecological effects of habitat amount and fragmentation: implications for the debate. Landscape Ecology, 22, 811-820.

Laurance, W. F., Nascimento, H. E. M., Laurance, S. G., Andrade, A., Ribeiro, J. E. L. S., Giraldo, J. P., Lovejoy, T. E., Condit, R., Chave, J., Harms, K. E., \& D'Angelo, S. (2006) Rapid decay of tree-community composition in Amazonian forest fragments. Proceedings of the National Academy of Sciences, 103, 19010-19014.

Lawler, J. J. \& Edwards, T. C. Jr. (2006) A variance-decomposition approach to investigating multiscale habitat associations. Condor, 108, 47-58.

Legendre, P. \& Legendre, L. (1998) Numerical Ecology: Second English Edition. Elsevier Science B.V., Amsterdam.

Martensen, A. C., Pimentel, R. G., \& Metzger, J. P. (2008) Relative effects of fragment size and connectivity on bird community in the Atlantic Rain Forest: Implications for conservation. Biological Conservation, 141, 2184-2192.

McGarigal, K. \& Marks, B. J. (1995) FRAGSTATS: Spatial pattern analysis program for quantifying landscape structure. General Technical Report PNW-GTR-351.

Petraitis, P. S., Dunham, A. E., \& Niewiarowski, P. H. (1996) Inferring Multiple Causality: The Limitations of Path Analysis. Functional Ecology, 10, 421-431.

R Development Core Team (2007) R: A language and environment for statistical computing. R: A language and environment for statistical computing, Vienna, Austria.

Saab, V. (1999) Importance of spatial scale to habitat use by breeding birds in riparian forests: A Hierarchical Analysis. Ecological Applications, 9, 135-151.

Santos, B. A., Peres, C. A., Oliveira, M. A., Grillo, A., Alves-Costa, C. P., \& Tabarelli, M. (2008) Drastic erosion in functional attributes of tree assemblages in Atlantic forest fragments of northeastern Brazil. Biological Conservation, 141, 249-260.

Shipley, B. (2000) Cause and correlation in Biology: A user's guide to Path analysis, Structural Equations and causal inference. Cambridge University Press, Cambridge.

Stotz, D., Fitzpatrick, J. W., Parker III, T. A., \& Moskovits, D. K. (1996) Neotropical birds: ecology and conservation. University of Chicago Press, Chicago. 
Trzcinski, M. K., Fahrig, L., \& Merriam, G. (1999) Independent effects of forest cover and fragmentation on the distribution of forest breeding birds. Ecological Applications, 9, 586-593.

van Dorp, D. \& Opdam, P. (1987) Effects of patch size, isolation and regional abundance on forest bird communities. Landscape Ecology, 1, 59-73.

Villard, M. A., Trzcinski, M. K., \& Merriam, G. (1999) Fragmentation effects on forest birds: relative influence of woodland cover and configuration on landscape occupancy. Conservation Biology, 13, 774-783. 
Table 1. Upper panel shows the coefficient of determination $\left(R^{2}\right)$ for simple and multiple regression models on bird community attributes with habitat quality, cover and configuration as explanatory variables. All regression models were significant at $P \leq 0.05$. The lower panel presents the results from the variation partitioning in which we computed the $R^{2}$ of the unique contribution specific to each factor and the shared contribution across factors. None of the unique contributions were significant at $P \leq 0.05$. Shared contribution cannot be tested for significance and may show negative $R^{2}$ when the interaction of explanatory variables explain the response variable better than the sum of the individual effects.

\begin{tabular}{|c|c|c|c|c|c|c|c|c|}
\hline \multirow[b]{2}{*}{ Guilds } & \multirow[b]{2}{*}{ Response } & \multicolumn{3}{|c|}{ Simple regressions } & \multicolumn{4}{|c|}{ Multiple regression } \\
\hline & & Quality & Configuration & Cover & $\begin{array}{c}\text { Quality + } \\
\text { Configuration }\end{array}$ & $\begin{array}{c}\text { Quality + } \\
\text { Cover }\end{array}$ & $\begin{array}{c}\text { Cover }+ \\
\text { Configuration }\end{array}$ & $\begin{array}{c}\text { Quality + } \\
\text { Cover }+ \\
\text { Configuration }\end{array}$ \\
\hline \multirow{2}{*}{ All species } & Abundance & 0.29 & 0.49 & 0.35 & 0.51 & 0.41 & 0.51 & 0.55 \\
\hline & Richness & 0.33 & 0.28 & 0.34 & 0.39 & 0.43 & 0.34 & 0.44 \\
\hline \multirow{2}{*}{$\begin{array}{l}\text { Sensitive } \\
\text { species }\end{array}$} & Abundance & 0.45 & 0.88 & 0.85 & 0.90 & 0.88 & 0.90 & 0.92 \\
\hline & Richness & 0.45 & 0.79 & 0.84 & 0.83 & 0.87 & 0.85 & 0.88 \\
\hline \multirow{2}{*}{$\begin{array}{l}\text { Generalist } \\
\text { species }\end{array}$} & Abundance & 0.11 & 0.54 & 0.68 & 0.55 & 0.70 & 0.68 & 0.71 \\
\hline & Richness & 0.11 & 0.62 & 0.68 & 0.64 & 0.70 & 0.68 & 0.71 \\
\hline \multirow[t]{2}{*}{ Community } & composition & 0.34 & 0.87 & 0.88 & 0.87 & 0.88 & 0.91 & 0.91 \\
\hline & & \multicolumn{3}{|c|}{ Unique contribution } & \multicolumn{4}{|c|}{ Shared contribution } \\
\hline Guilds & Response & Quality & Configuration & Cover & $\begin{array}{c}\text { Quality + } \\
\text { Configuration }\end{array}$ & $\begin{array}{c}\text { Quality + } \\
\text { Cover }\end{array}$ & $\begin{array}{c}\text { Cover }+ \\
\text { Configuration }\end{array}$ & $\begin{array}{c}\text { Quality + } \\
\text { Cover }+ \\
\text { Configuration }\end{array}$ \\
\hline \multirow{2}{*}{ All species } & Abundance & 0.04 & 0.14 & 0.03 & 0.03 & -0.01 & 0.09 & 0.23 \\
\hline & Richness & 0.09 & 0.01 & 0.05 & -0.01 & 0.02 & 0.05 & 0.23 \\
\hline \multirow{2}{*}{$\begin{array}{l}\text { Sensitive } \\
\text { species }\end{array}$} & Abundance & 0.02 & 0.04 & 0.01 & 0.01 & 0.00 & 0.42 & 0.41 \\
\hline & Richness & 0.03 & 0.00 & 0.05 & 0.00 & 0.01 & 0.37 & 0.40 \\
\hline \multirow{2}{*}{$\begin{array}{l}\text { Generalist } \\
\text { species }\end{array}$} & Abundance & 0.02 & 0.00 & 0.15 & 0.00 & -0.01 & 0.44 & 0.09 \\
\hline & Richness & 0.03 & 0.01 & 0.07 & 0.00 & -0.01 & 0.53 & 0.09 \\
\hline Community & composition & 0.00 & 0.02 & 0.03 & 0.00 & 0.00 & 0.51 & 0.34 \\
\hline
\end{tabular}


Table 2 - Stepwise backward model selection for SEM models using measures of habitat quality (PC1 and PC2), habitat cover and habitat configuration to explain the species richness and abundance of the total bird community, sensitive species, generalist species and the total community composition. Estimates used for backward deletion were based on AIC values and their computed evidence ratios, but additionally the chisquare $\left(\chi^{2}\right)$ and the coefficient of determination $\left(R^{2}\right)$ are reported for ease of interpretation of model adequacy. The evidence ratio of 1.00 indicates the best models (with lowest AIC values), and model fit is considered to be significantly poorer when the evidence ratio is larger than 2.00. Models are organised from full ( $a$ ) to the most parsimonious ( $c$ or $d$ ).

\begin{tabular}{cccccc|ccccc}
\hline & \multicolumn{1}{c}{ Abundance } & \multicolumn{5}{c}{ Richness } \\
\hline & Model & $\chi^{2}$ & $R^{2}$ & $\begin{array}{c}\text { Evid. } \\
\text { Ratio }\end{array}$ & Exclusion & $\chi^{2}$ & $R^{2}$ & $\begin{array}{r}\text { Evid. } \\
\text { Ratio }\end{array}$ & Exclusion \\
Total & a & 1.4 & 0.54 & 7.73 & & 1.4 & 0.5 & 2.70 & \\
community & b & 1.5 & 0.55 & 2.84 & Quality PC1 & 2.1 & 0.48 & 1.36 & Configuration \\
& c & 3.1 & 0.51 & 1.12 & Quality PC2 & 4.7 & 0.43 & 1.00 & Quality PC1 \\
& d & 4.3 & 0.49 & 1.00 & Cover & 7.7 & 0.34 & 1.91 & Quality PC2 \\
Sensitive & a & 1.4 & 0.92 & 2.45 & & & & & \\
species & b & 1.6 & 0.92 & 1.00 & Quality PC1 & 1.6 & 0.88 & 1.93 & Configuration \\
& c & 5.0 & 0.90 & 2.03 & Cover & 2.3 & 0.87 & 1.00 & Quality PC1 \\
& & & & & & & & & \\
Generalist & b & 1.4 & 0.71 & 6.17 & & 1.4 & 0.77 & 1.59 & \\
species & c & 1.6 & 0.71 & 2.51 & Configuration & 2.4 & 0.76 & 1.00 & Configuration \\
& d & 3.7 & 0.70 & 1.07 & Quality PC1 & 5.2 & 0.72 & 1.46 & Quality PC2 \\
& & & 1.00 & Quality PC2 & 7.3 & 0.68 & 1.51 & Quality PC1 \\
& a & 1.4 & 0.91 & 4.60 & & & & & \\
Community & b & 1.8 & 0.91 & 2.15 & Quality PC2 & & & & \\
composition & c & 2.3 & 0.91 & 1.00 & Quality PC1 & & & & \\
\hline
\end{tabular}




\section{Figure Legends}

Figure 1 - a) Example of a full structural equation model in which all exploratory variables directly affect the response variable (species richness, abundance or composition). A single latent variable “Anthropogenic disturbance” was created to explicitly account for the high correlation among the variables representing habitat cover, habitat configuration and habitat quality (PCA2) in the model. The first axis of the habitat quality variable (PCA1) was not correlated with the remaining variables and was therefore modelled as an exogenous variable. Anthropogenic disturbance is the only latent variable in the model (oval), while the remaining variables and their measurement errors (“er”) were all measured (rectangles). b) Final structural equation model in which the response variable is the first axis of a PCoA representing changes in community composition. The links between the two variables of habitat quality and the response variables were removed during model selection. The links from habitat configuration and habitat quality show the standardised coefficients were significant with $P<0.05$.

Figure 2 - Venn diagram representing the variation partitioning results achieved for the models built for (a) total species richness and (b) total community composition. Each circle represents habitat quality, cover or configuration, with circle size being proportional to the $R^{2}$ obtained for each variable in a simple regression of that variable on the response variable (for values see Table 1). Overlapping sections represent the shared contribution between two or more variables. Both panels show that most of the influence from each environmental variable was a shared contribution such that the unique contribution from habitat quality, habitat cover or habitat configuration was nonsignificant. In (a) habitat configuration is fully subsumed within the effect of habitat cover, whereas in (b) the contribution of habitat quality is fully subsumed within those of habitat cover and configuration. 
Figure 1

a)

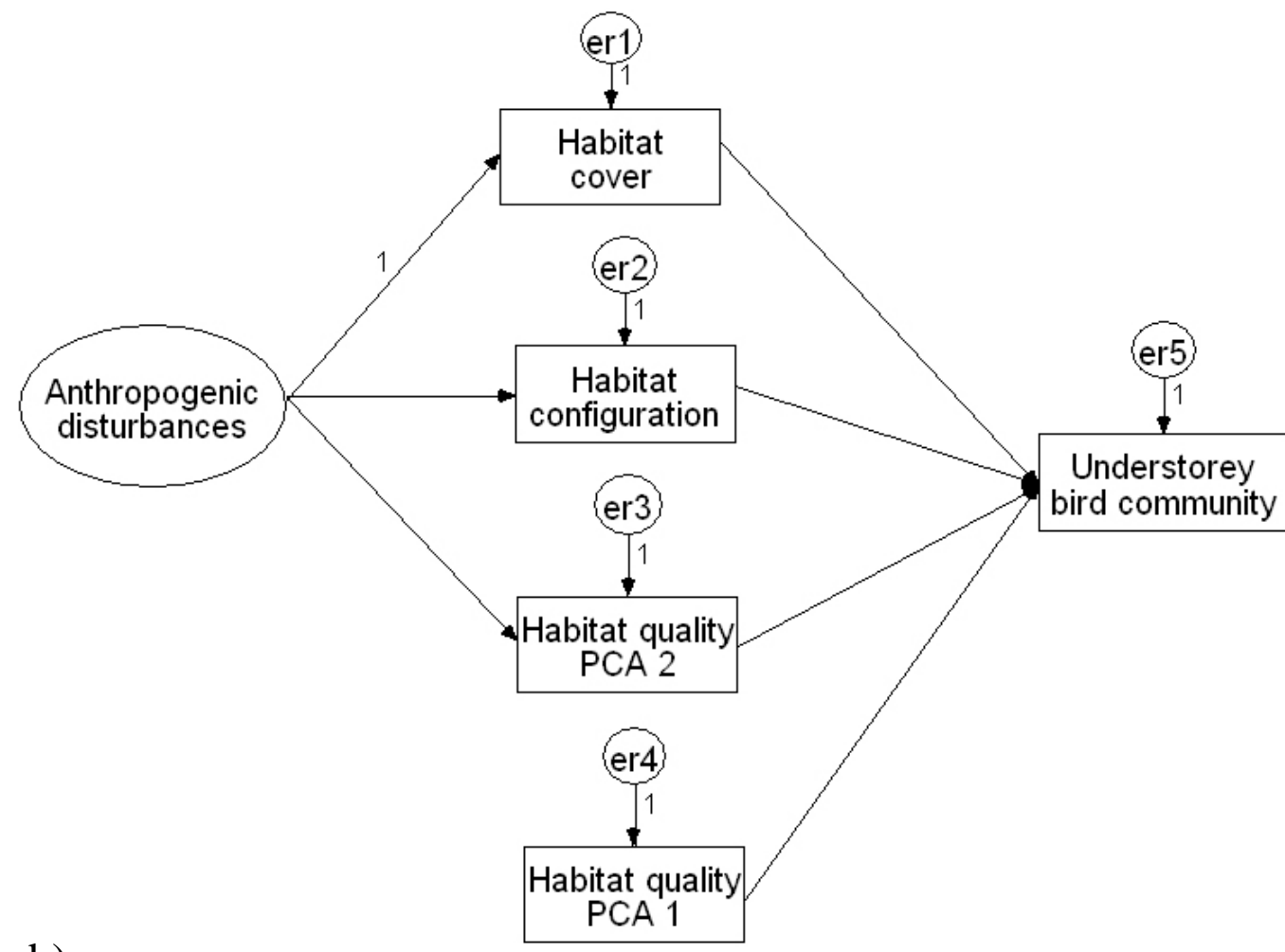

b)

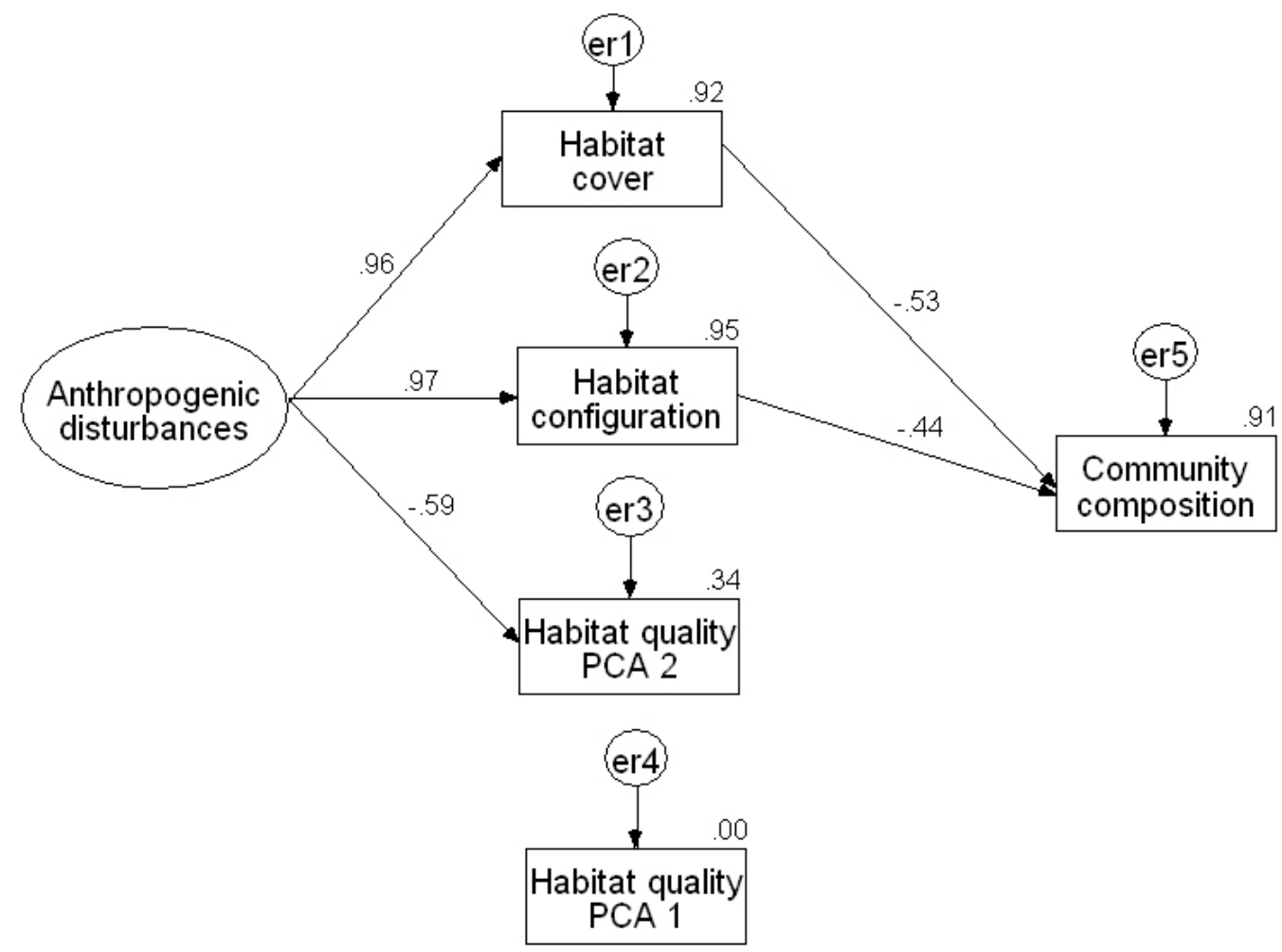


Figure 2
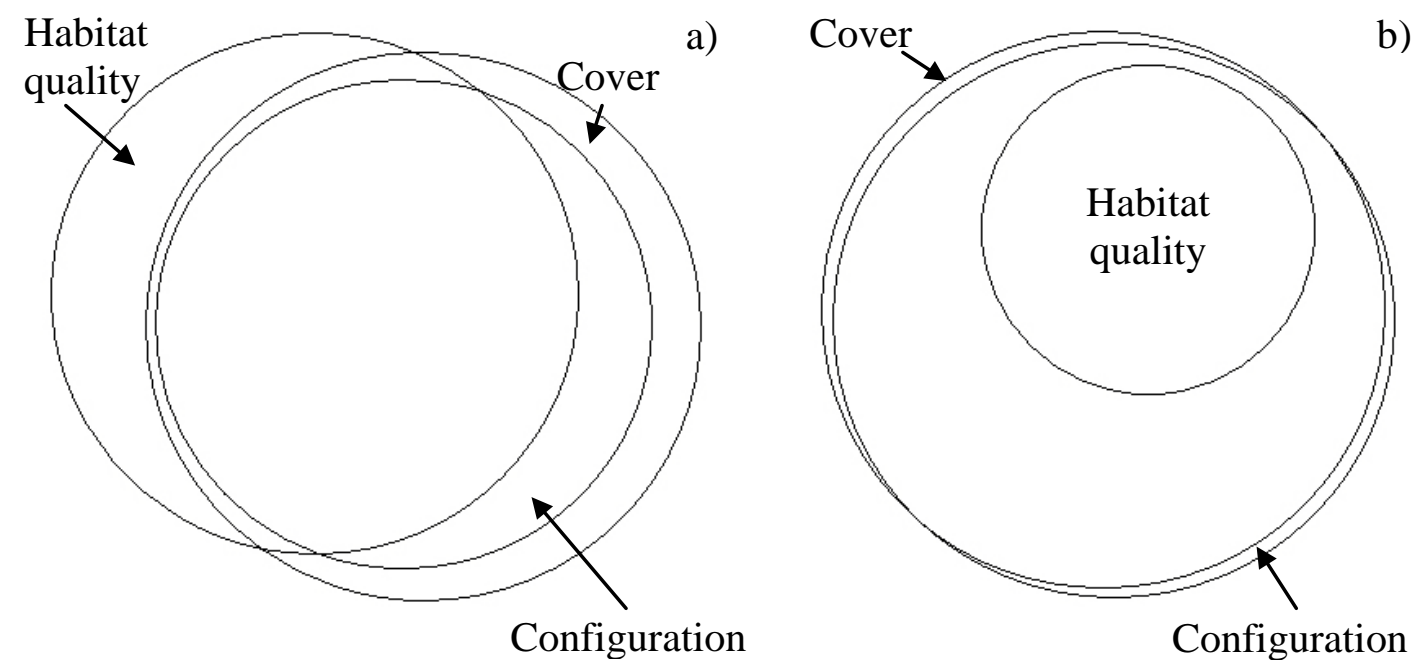


\section{Capítulo 5}

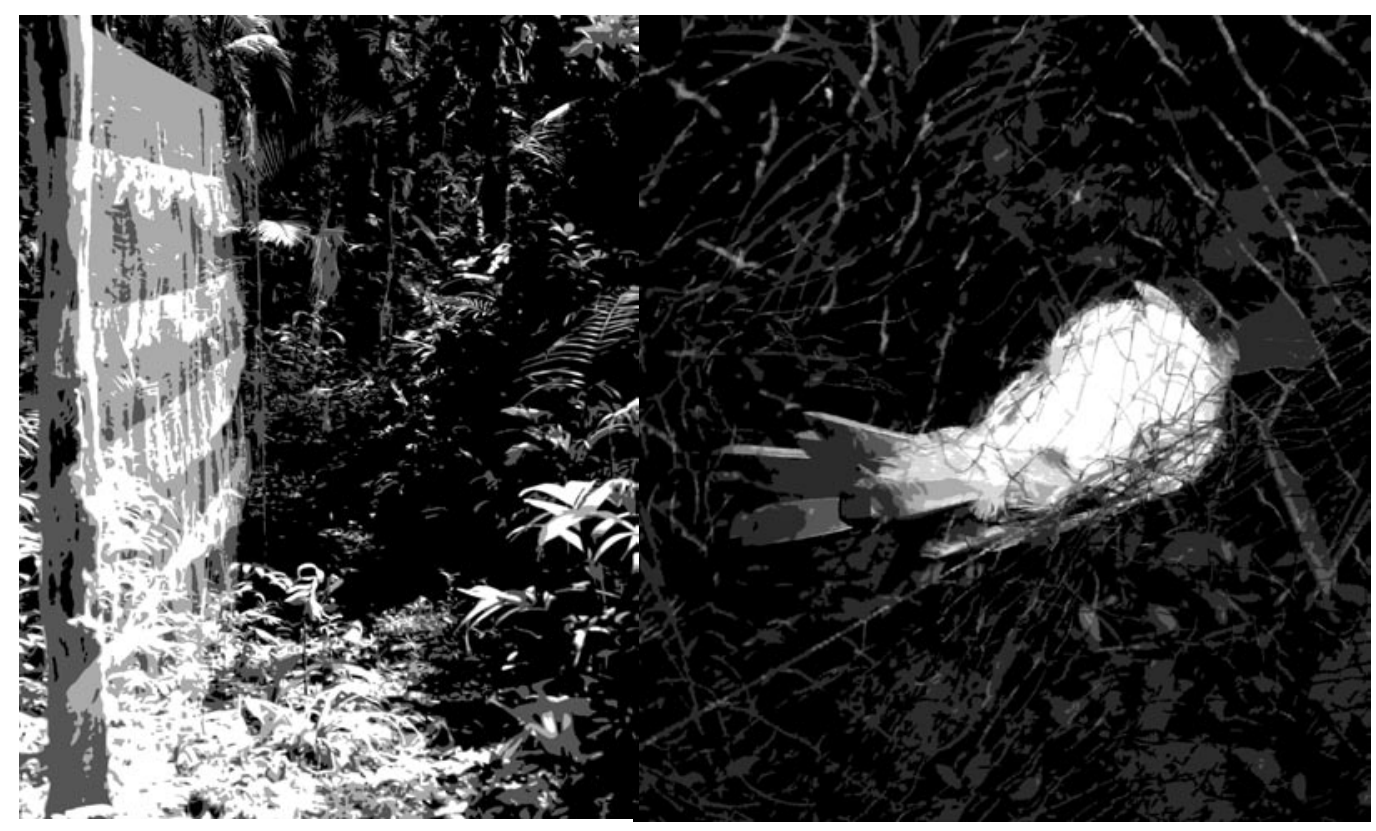




\section{Capítulo 5}

Temporal sampling protocol influences the detection of ecological patterns

Cristina BANKS-LEITE, Robert M. EWERS, Rafael G. PIMENTEL \& Jean Paul METZGER 


\section{Resumo}

Variações na detecção de espécies dentro de uma mesma área é um problema comum a muitas amostragens e pode ter forte influência sobre os dados coletados. Tal variabilidade pode ser causada por baixa acurácia dos métodos, o que pode ser resolvido com maior esforço amostral, ou por mudanças comportamentais das espécies ao longo do tempo, o que significa que a forma como o protocolo temporal é criado é bastante importante. Aqui nós usamos o exemplo de captura de aves por redes de neblina para avaliar se decisões sobre a forma como o protocolo temporal de amostragem é criado pode produzir inconsistências nos dados coletados e como isso pode afetar os padrões ecológicos que um projeto pode detectar. Com um banco de dados possuindo quase 3.400 capturas durante 21.000 horas-rede e em 31 sítios amostrais na Mata Atlântica, nós investigamos como a captura de aves variava ao longo do dia, entre estações seca e chuvosa e entre anos. Nós também verificamos como diferenças no protocolo de amostragem poderiam afetar estimativas de riqueza de espécies e composição da comunidade, e se estas diferenças poderiam alterar a magnitude, e probabilidade de detecção, de padrões ecológicos, como a relação espécie-área. Nós encontramos que a taxa de captura de aves era significativamente maior de manhã do que à tarde, era maior na estação seca do que na chuvosa, e também encontramos que a captura de aves não diminuiu ao longo dos anos, como seria de se esperar caso as aves aprendessem a localização das redes e passassem a evitá-las. Estimativas de riqueza de espécies e de composição da comunidade não mostraram alterações quando calculadas a partir de diferentes períodos do dia ou diferentes estações do ano, porém foram consideravelmente diferentes entre amostragens de curta duração (e.g. um dia de amostragem). A magnitude dos padrões ecológicos mostrou-se insensível a diferenças no protocolo amostral, mas a probabilidade de detecção foi fortemente alterada dependendo da estação amostrada e do tamanho do esforço amostral utilizado. Nós encontramos que a distribuição temporal do esforço amostral era mais importante do que o tamanho deste. Por fim, discutimos que projetos com o mesmo desenho amostral espacial, mas com pequenas diferenças no protocolo temporal de coleta, podem encontrar padrões ecológicos inconsistentes e conseqüentemente gerar estratégias conservacionistas inadequadas. Nossos resultados também levantam a dúvida sobre amostragens de curta duração como aquelas utilizadas em EIA/RIMA 


\section{Summary}

Within-site variability in species detectability is a problem common to many biodiversity assessments and can strongly bias the results. Such variability can be caused by simple counting inaccuracies, which can be solved by increasing sample size, or by temporal changes in the way species respond to their habitat, which means that the way the temporal sampling protocol is designed is also very important. Here, we use the example of mist-netted birds to determine if design decisions in the temporal sampling protocol can produce inconsistencies in the data collected and how these might affect the ecological patterns a project may detect. Using data from almost 3,400 birds captured from 21,000 net-hours at 31 sites in the Brazilian Atlantic forest, we investigated how bird capture rates varied at three temporal scales: through the day, between dry and wet seasons and among years. We then assessed whether differences in sampling protocol could alter estimates of species richness and community composition, or change the magnitude of ecological trends, such as the species-area relationship (SAR), and the probability of detecting them. We found that bird capture rates were consistently higher in the morning than in the afternoon, were higher in the dry than in the wet season, and did not decrease over time as expected from the hypothesis that birds become net-shy as sampling continues. Estimates of species richness and community composition were similar when calculated from data collected at different periods of the day and from different seasons, but substantially dissimilar among repeated surveys of short duration (i.e. one day). The magnitude of ecological trends was generally insensitive to sampling period, but the probability of detecting those relationships was greatly altered when sampling was conducted in only one season or with a short sampling period. We found that the temporal distribution of sampling effort was more important than the total amount of sampling effort. We discuss that projects with the same spatial sampling design, but with slight differences in temporal sampling protocol, could report inconsistent ecological patterns which may ultimately lead to the application of inappropriate conservation strategies. Our results raise questions about the reliability of snapshot surveys and rapid biodiversity assessments.

Key-words: Atlantic forest, Brazil, mist-nets, protocol, sample size, seasonality, trapping methods, understorey birds. 


\section{1 - Introduction}

At the start of ecological projects, decisions have to be taken about the sampling design used for collecting data. To achieve the most appropriate design to address a certain question, there are a number of considerations that researchers must have in mind in order to obtain the best data and consequently generate reliable inferences from their results. One important matter to be considered is that species detectability changes though time at any given site (Cam et al., 2002; Link \& Sauer, 2007). This within-site variability can be caused by either detection imperfections common to all methods and techniques (Link et al., 1994), or by biological reasons, such as species responding in a different way to their environment through time (Fleishman et al., 2002). If species behaviour does not change with time, then similar results should be achieved if a site is surveyed for many days in a row or in different seasons and/or years, as it is mainly dependent on sample size. However, if species respond differently to their environment though time, then a large sample size alone should not be enough to guarantee robust data, as the temporal allocation of sampling effort might strongly influence the results.

It is generally expected that design decisions in the temporal sampling protocol will influence the data collected (Field et al., 2002; Fleishman et al., 2002; Esberard, 2006). However, this issue has received much less attention than the role of sample size (eg. Heck et al., 1975; Mac Nally, 1997; Chao et al., 2009) and there is even evidence suggesting the contrary, that changes in the temporal sampling protocol do not pose a great influence on ecological data overall (Mac Nally et al., 2004). Nonetheless, considering that most animals have complex behaviour with diurnal and seasonal patterns, the way the sampling protocol is designed temporally might exert a stronger influence on the results of ecological projects than is realised.

The capture of birds with mist-nets provides good conditions to test if the way the temporal protocol is designed affects the quality of the data collected and how those 
design decisions might alter the results and inferences arising from a project. Birds have a well-known biology and mist-netting is a standard technique that allows researchers to perform surveys throughout the year (Wiens, 1992; Sutherland et al., 2004). Moreover, many of the drawbacks of using mist-nets and alterations in capture efficiency due to changes in bird behaviour have already been recognised (Remsen \& Good, 1996). For instance, the rate at which birds are captured by mist nets is a function of their activity pattern, so any factor capable of influencing bird activity will also affect capture rates, such as weather, season, time of day, habitat structure and biological traits (Remsen \& Good, 1996). Among these potential influences, time of day is considered to be one of the foremost factors influencing net captures and it is often suggested that more birds are captured in the early morning and late afternoon, while the noon period is thought to have a considerably lower capture rate (Ralph, 1976; Karr, 1981). Another central issue is the season in which sampling is performed (Quinlan \& Boyd, 1976). Migratory activities, temperature, changes in resource abundance and in the breeding behaviour of birds are all factors capable of having a profound influence on bird activity (Faaborg et al., 1984; Jenni \& Leuenberger, 1996; Develey \& Peres, 2000). Another equally important factor, especially for studies aiming at using capture-recapture data, is that birds are expected to avoid nets once captured such that capture rates should decrease after sampling a given place for a long time (MacArthur \& MacArthur, 1974; Manly, 1977).

If so many factors can affect capture rate and if bird captures forms the primary data being used for estimating species richness and community composition, it is to be expected that these estimates could be either biased or unreliable depending on the protocol chosen for sampling. Moreover, analyses using those estimates could also produce biased and inaccurate results, such as analyses of the species-area relationship 
(SAR), which are often one of the desired results of ecological projects. This question also has considerable importance in conservation biology as two different studies conducted in the same system but with different temporal protocols could find inconsistent outcomes, resulting in conflicting proposals for management actions.

To evaluate how design decisions about the temporal allocation of sampling effort can affect the results and inferences from a project, we assessed how temporal differences in species behaviour influence net captures, and whether estimates of community attributes and the outcomes of ecological analyses are also sensitive to temporal sampling patterns. We employed a dataset of bird communities in Brazilian Atlantic forest collected from more than 22,000 net hours sampling effort over a twoyear period. In this study we aimed to (1) understand how the capture rate changes along three temporal scales: within a day, between seasons (dry and wet season) and with increasing sampling-effort across years; (2) to assess if changes in capture rate affect estimates of species richness and community composition; and (3) we used the SAR (species-area relationship) as a model for investigating how ecological patterns, and the probability of detecting them, would change if we had sampled at just one period of the day, one season, or with reduced sampling effort.

\section{2 - Methods}

Study Site

The study was conducted in the Atlantic Plateau of the State of São Paulo, Brazil. The original vegetation in the area is classified as lower montane Atlantic forest, the mean altitude is $870 \mathrm{~m}$ above sea level, the mean annual temperature is $19^{\circ} \mathrm{C}$ and annual rainfall is $1,808 \mathrm{~mm}$ (www.cpa.unicamp.br). The dry season comprises the period between April and September; which are also the coldest months of the year (Fig. 1). Bird sampling was mostly conducted in a fragmented landscape $\left(23^{\circ} 50^{\prime} \mathrm{S}, 47^{\circ} 20^{\prime} \mathrm{W}\right.$ ) 
of approximately 10,000 ha, of which $50 \%$ was covered with second-growth forest of varying ages. We also sampled an adjacent forested area, the State Park of Jurupará, which spreads over two contiguous blocks of forest of approximately 6,700 ha and 14,800 ha, respectively. Birds were sampled in 27 sites in the fragmented landscape and in 4 sites located inside the State Park.

\section{Bird captures}

Birds were sampled using 10 mist nets (12 m length, $2.5 \mathrm{~m}$ high, $31 \mathrm{~mm}$ mesh) positioned in a single line that was as straight as possible and followed the slope contour. We sampled each of the 31 sites in four surveys of two consecutive days. In the first day, nets were opened at sunrise and closed at sunset (with a 5 minute precision). On the second day, nets were opened at sunrise and closed six hours later, so each survey had a total of approximately 170 net-hours (10 mist nets by site opened for 17 hours). Nets were closed whenever there was a heavy rain. Each site was surveyed twice in the dry season (austral winter of 2005 and 2006) and twice in the wet season (summer of 2005/2006 and 2006/2007), until we reached a total of 680 net-hours per site. Nets were checked every hour and the time of capture for individual specimens was recorded. All captured birds were marked with a numbered aluminum band provided by Center of Research for Conservation of Wild Birds (CEMAVE - IBAMA) and released in the vicinity.

\section{Analysis}

Diurnal, seasonal and annual influences on capture rate

To understand how the patterns of bird capture changed through the day, we grouped all the captures recorded in the 30 minutes earlier and later than full hours (i.e. 
all birds captured from 9:30 to 10:30 were assigned to the 10:00 hour). We further divided the day into two periods: the morning period comprising sunrise $(\sim 6: 00)$ to noon (12:00), and the afternoon period from 13:00 to sunset ( 18:00). When analysing differences in capture rate due to within-day variations, we used only the full days of sampling to follow the same protocol used by earlier studies (Ralph, 1976; Karr, 1981); the second day, when only the morning hours were sampled, was not included. To test for differences in capture rates between the dry and wet seasons, we pooled the netcapture data collected in the two consecutive years, to obtain just one record per site per season. We then pooled the data from sequential surveys to check for differences in capture rate with increasing sampling effort (170, 340, 510 and 680 net-hours). Finally, to check if captured birds tend to avoid nets in the future, we compared the four surveys of 170 net-hours for differences in capture rate (total number of records), capture rate of new individuals, and recapture rate (previously captured birds).

To analyse the data, we used generalised linear mixed models with Poisson errors for nested count data. In all our models we controlled for pseudoreplication by fixing the effects of site, which made the analyses analogous to paired $t$-tests and repeated measures ANOVA. In models with Poisson errors, the change in deviance attributable to the explanatory variables is distributed as a chi-squared distribution; thus hypothesis testing was performed by sequentially removing one explanatory variable from the full model and testing for a resulting change in deviance. To test for differences among the levels of each factor we grouped the levels and checked for significant increases in deviance. If the result was significant we retained the levels separately in the final model. We also performed the same procedure, but using Binomial errors instead of Poisson, to test for differences in recapture rate, controlling for the fact that they would be higher in places with more captures. 
$\underline{\text { Community attributes and ecological patterns }}$

To test if estimates of observed species richness and community composition would be affected by changes in sampling protocol, we calculated the Pearson correlation index for species richness, and a Mantel test for community composition by calculating the Bray-Curtis dissimilarity index on standardized abundances (ranging from 0 to 1) for each of the three temporal scales, using sites as replicates. High correlation values among different periods would reveal that the structure of the data across sites (the relative estimates of richness and community composition) would be similar if surveys were restricted to only one of these periods. However, these analyses do not indicate whether the absolute species composition present at each period would change; therefore as an auxiliary analysis, we performed an analysis of similarities (ANOSIM) to evaluate whether different species were being captured in different periods of the day or year.

To assess whether variation in sampling protocol could affect the outcome of ecological analyses, we used one of the most common analyses in ecology, the speciesarea relationship (SAR). We used data from 18 independent sites in forest fragments and the four sites located in the State Park and ran a series of simple linear regressions of species richness against two different explanatory variables: patch size (logtransformed richness and area) and the percentage of forest cover in an $800 \mathrm{~m}$ radius around the sampling point. From each regression we recorded the slope value $( \pm 1$ standard error), the residual sum of squares, degrees of freedom and the model $P$-value. Using these values we tested for differences between slopes with a modification of the $t$ test described in Zar (1996). We tested whether slopes and $P$-values would be different (1) if we had sampled in only the morning or afternoon period; (2) if we had sampled 
only in the dry or wet season; (3) among the four 170 net-hour surveys and (4) with increasing sampling effort (170, 340, 510 and 680 net-hours).

For a number of reasons, we used observed species richness and not estimators of richness in the above analyses. First, because the degree of bias, inaccuracy and imprecision of estimators is dependent on the sample coverage, which is a function of sampling effort (Brose et al., 2003). Thus, for our purposes, no single estimator would adequately suit all data subsets as we used a different sampling effort for each question. Second, little is gained from using richness estimators to assess the species-area relationship if data comes from a standardized sampling effort (Borges et al., 2009). Third, small patches in fragmented landscapes not only have decreased richness, but also have a lower carrying capacity (Schooley \& Branch, 2007), suggesting that species abundances in small patches will be reduced, leading to a probable overestimation of richness in small patches when compared to large ones. Preliminary analysis showed that capture rates increased with patch size (Supp. Mat.), however recapture rates decreased with patch size (Supp. Mat.), providing further support for the idea that there are both less species and less individuals present in smaller patches. Finally, most published papers on the SAR use observed richness and not estimated richness (Brose et al., 2003), so our results will be more relevant to the research community if they are also based on observed richness.

Finally, to check if changes in the outcome of ecological analyses could be attributed to differences in sample size alone (i.e. amount of sampling effort), we built sample-based rarefaction curves in the software EstimateS v.7 (Colwell, 2004). With this procedure, any possible temporal effect would disappear as the species richness for each sample size is achieved by random permutations of the data. We also built, for each site, sample-based accumulation curves of the richness of the understory-obligate 
bird species, as defined by Stotz et al. (1996). All other analyses were performed in the R program v.2.5.1 (R Development Core Team, 2007).

\section{3 - Results}

We recorded a total of 2,681 individuals belonging to 115 species from 3,381 captures. Accumulation curves showed that even after 680 net-hours we did not reach an asymptote in total species richness in any of the sites (Fig. 2a). The exclusion of the species belonging to the canopy and/or midstorey strata did not change the shape of the species accumulation curves (Fig. 2b); and also, inspection of the data suggests that some birds might be misclassified for this region as many of these species were commonly captured in the understorey (e.g. 165 captures of Sittasomus griseicapillus, 72 captures of Haplospiza unicolor, Anexo II). Consequently, all further analyses were conducted on the full dataset.

\section{Variation in bird captures across three temporal scales}

The number of birds captured changed significantly along the day $\left(\chi^{2}=400, \mathrm{df}=\right.$ $13, P<0.0001)$. In the second hour of the day we captured an average of 11.2 birds per sampling site, which was significantly higher than any other hour of the day (Fig. 3a). In the following hours we observed a steady decline in bird captures until the seventh hour of the day ( 12:00) when we captured an average of 6.6 birds per site. The afternoon period (from $~ 13: 00$ and on) showed a consistently low capture rate of 3.9 birds. However the pattern of bird capture along the day was influenced by season. In the wet season, capture rates were higher during the first four hours after sunrise, peaking in the second hour of day at an average 6.2 birds per site, while from 10:00 am until the rest of the day capture rates varied slightly around 1.9 birds per hour per site 
$\left(\chi^{2}=223 \mathrm{df}=13, P<0.0001\right.$; Fig. 3b). In the dry season there were two distinct periods of capture rates; the morning period when we captured an average of 4.9 birds per hour per site, and the afternoon period when we had an average of 2.3 captures $\left(\chi^{2}=133\right.$, df $=10, P<0.0001$, Fig. 3c). In the dry season, the mean capture rate was 57.2 birds per site, which was significantly higher than in the wet season $\left(\right.$ mean $=48.2, \chi^{2}=24.0, \mathrm{df}=$ 1, $P<0.0001)$.

The number of bird captures decreased across surveys $\left(\chi^{2}=48.87, \mathrm{df}=3, P<\right.$ 0.0001), but this decrease was only significant from the first to the second survey, which had a capture rate similar to subsequent surveys $\left(\chi^{2}=4.22, \mathrm{df}=2, P=0.121\right.$; Fig. 4a). This pattern was a combination of the decrease in the capture rate of new individuals $\left(\chi^{2}=57.35, \mathrm{df}=3, P<0.0001\right.$; Fig. $\left.4 \mathrm{~b}\right)$ counterbalanced by an increase in the number of recaptured individuals $\left(\chi^{2}=264.29, \mathrm{df}=3, P<0.0001\right.$; Fig. $\left.4 \mathrm{c}\right)$. In the first two surveys, recaptured individuals comprised around $10 \%$ of the total captures, while in the last two surveys this proportion increased to $25 \%$.

\section{Correlations among species richness and community composition}

We found a significant correlation across all sites between the morning and the afternoon in species richness $(r=0.423, P=0.017)$ and in community composition $(r=$ 0.458, $P<0.001$ ), and we also found a similar result between dry and wet season (Table 1). While species richness was poorly correlated among surveys of 170 net-hours, results were more consistent for community composition and among surveys of 340 nethours (Table 1). Although the relative structure of the bird community across all sites remained fairly similar, the absolute community composition changed significantly from morning to the afternoon period $\left(F_{1,61}=10.03, P<0.001\right)$, from dry to wet season $\left(F_{1,61}=2.75, P<0.001\right)$ and among different surveys $\left(F_{3,123}=2.46, P<0.001\right)$. 
Ecological patterns and the power to detect them

There was a significant and positive relationship between total species richness (680 net-hours) and both patch area $\left(R^{2}=0.286\right.$, Slope $\left.=0.045, F_{1,20}=8.01, P=0.010\right)$ and forest cover $\left(R^{2}=0.342\right.$, Slope $\left.=0.133, F_{1,20}=10.4, P=0.004\right)$. The regression slope estimates did not change significantly when we repeated the analysis using data from a single period of the day, single season or from a different total sampling effort. However, the interpretation of those results would have changed as the $P$-values in many cases went from significant to non-significant (Fig. 5). For instance, if we had performed the surveys only in the morning period we would have found the same ecological patterns as found for the full sampling, but we would not have detected a significant pattern if we had sampled just the afternoon period. In the dry season we would have found a significant pattern $(P=0.002)$ of species richness increasing with patch size (Fig. 5d), but if we had performed the surveys in the wet season, we would have concluded that patch size does not affect species richness $(P=0.145)$. A similar bias would have occurred if we had performed surveys of 170 net-hours to estimate bird responses to forest cover. Using a 170 net-hour survey, we would detect a significant pattern just one in four times (Fig. 5e). However, this variability in results was reduced by combining data from two or more surveys (> 340 net-hours; Fig. 5g,h).

The analyses performed on rarefied species richness, on the other hand, yielded more constant results as sample size was varied (170, 340, 510 and 680 net/hours). The slope estimates obtained from the regressions against patch size and forest cover were also fairly constant (Slope Patch size: mean $=0.05$, SD $=0.01$, Slope Forest cover: mean $=0.10, \mathrm{SD}=0.02$ ) but, in all cases, were significant at a $P$-value $\leq 0.01$. 


\section{4 - Discussion}

In this study, bird captures varied significantly through the day, between seasons and across surveys; but these results were somewhat expected (Ralph, 1976; Manly, 1977; Faaborg et al., 1984; Malizia, 2001). Less expected were the results about how such temporal variation in capture rates also affected the estimates of species richness and community composition. This trend has been rarely reported (Mac Nally, 1997; Barlow et al., 2007), although is generally expected to be present (Mac Nally, 2002). It was, however, surprising to find that the detection of ecological trends, such as the speciesarea relationship, was strongly altered depending on the temporal allocation of sampling effort. Although the potential for sampling methods to alter ecological results has been previously suggested (Fleishman \& Mac Nally, 2003; Mac Nally et al., 2004), to our knowledge this is the most extreme case of how such widespread analyses are sensitive to variations in sampling protocol.

There are two, non-mutually exclusive, hypotheses that could explain why the chance of detecting ecological trends changes temporally; one is biological and the other methodological. In the biological hypothesis, the detection of ecological relationships changes temporally because species are differentially affected by their environment through time. This hypothesis was supported by Fleishman et al. (2002) when investigating the relative influence of patch metrics and quality on a butterfly metapopulation. These authors reported that the strength of the ecological relationships was dependent on the temporal scale in which the data had been obtained, and they suggested that such variation reflected how species are affected by different resources through time (Fleishman et al., 2002). Similarly, Barlow et al. (2007) found that habitat comparisons of a butterfly community in the forests of Eastern Amazonia was also influenced by the time of year when sampling was conducted. They suggested that these 
results were probably dependent on within-year variation in climate, habitat and the species present in the region. Similarly, it is possible that birds may show stronger responses to their environment (i.e. patch size) in times of resource scarcity (i.e. dry season); thereby causing the seasonal variation we found in the SAR results. Although this biological hypothesis may account for the seasonal variation in ecological patterns, it alone cannot explain the differences in the SAR results between the morning and afternoon period and with increasing sampling effort.

In the methodological hypothesis, the detection of ecological relationships would change due to within-site variability caused by random effects which could be minimised with a larger effort per site (Link et al., 1994). Such issues have been thoroughly studied (Mac Nally, 1997; Moreno \& Halffter, 2000; Mac Nally \& Horrocks, 2002; Field et al., 2002; Watson, 2003; Chao et al., 2009) and it is generally proposed that, to reduce the influence of random effects, a site should ideally be surveyed until the asymptote in the species accumulation curve is reached (Gotelli \& Colwell, 2001). In our study, we performed a considerably larger sampling effort in comparison to other studies conducted elsewhere in Brazil (see review in Barlow et al., 2006), and yet an asymptote in the species accumulation curve was not reached at any of the sampling sites (Fig. 2). Despite not fully sampling the community, we found that the consistency of community estimates and of SAR results increased considerably with increasing sampling effort. For instance, among short surveys (170 net-hours), we found that species richness and community composition were poorly correlated and the probability of detecting a significant SAR pattern was inconsistent. By doubling the sampling effort to 340 net-hours, results were more consistent among surveys and not dramatically altered by further increases in sampling effort (to 510 and 680 net-hours; Fig. 5). 
Nevertheless, the chance of detecting an ecological trend is not just a simple function of sampling effort and number of captures, as the SAR results found for the morning period (240 net-hours) were basically identical as those found for the full sampling (680 net-hours, Fig. 5a,b). This shows that we could have obtained the same ecological result with one third of the total effort as long as each site had been equally sampled over the two year period. Moreover, the results from the regressions performed on rarefied species richness showed that probability of detecting ecological trends remained significant at a $P$-value $\leq 0.01$, even when the sampling effort was reduced to 170 net-hours. This suggests that differences in the likelihood of detecting ecological patterns in such short-duration samplings (Fig. 5e,f) was a result of temporal variation in the data rather than differences in sample size alone. These results suggest that the temporal distribution of sampling effort, driven by temporal changes in species responses to their environment, is more important than the amount of effort alone in generating consistent and reliable inferences from ecological data.

However, it is also important to point out one caveat in these results: it is possible that such large variation in the probability of detecting a significant SAR trend was partly caused by the low strength of this relationship in the study area (Link et al., 1994). Our estimates of the species-area relationship were very low (Slope $=0.045$ for patch area and Slope $=0.133$ for forest cover) compared to what is typically expected in fragmented landscapes $(z=0.25$, Ewers \& Didham, 2006). There are two main reasons that might explain why our study site has such a low $z$ value. Firstly, in all sites we performed the same sample size (680 net-hours), while most studies typically conduct larger sampling effort in larger patches. Because the number of species observed is so heavily dependent on sample size (Gotelli \& Colwell, 2001), increasing effort with fragment size is likely to result in a stronger SAR. Second, the studied landscape was 
heavily forested (50\% of forest cover) and it is hypothesised that in highly connected landscapes the slopes from the SARs should be lower (Hubbell, 2001). Nevertheless, before a project is completed and data is collected it is impossible to know if ecological patterns will be weak or strong. Therefore, it is better to be safe and make sure that the project is employing a robust temporal design that takes into consideration the different behavioural responses of species through time.

In conclusion, our results show that studies with the same spatial sampling design, but with small differences in temporal sampling protocol (such as surveying in just one season or with reduced effort), could obtain different outcomes from ecological analyses. Although our study was conducted in a seasonal tropical forest using a single sampling method, we believe these results can be extrapolated to other systems in which species respond differently to their environment through time. Most importantly, our results show the risks of projects that seek to apply their findings in conservation strategies. In particular, our data suggests that conclusions drawn from rapid risk assessments should be treated cautiously, as survey data collected from very limited time periods may provide a misleading impression of ecological patterns which, in turn, could lead to inappropriate conservation and management actions.

\section{Acknowledgements}

We would like to thank all field assistants, in particular J.R. Mello Jr. and C.H. Parruco. We also thank J. Barlow, P.K. Lira, R. Mac Nally, J.C. Motta Jr, L.F. Silveira, A. Uezu for helpful comments on this manuscript. Research support was provided by CNPq, CAPES, Instituto de Biociências/USP, Imperial College London, SELVA and BIOCAPSP. 


\section{References}

Barlow, J., Overal, W. L., Araujo, I. S., Gardner, T. A., \& Peres, C. A. (2007) The value of primary, secondary and plantation forests for fruit-feeding butterflies in the Brazilian Amazon. Journal of Applied Ecology, 44, 1001-1012.

Barlow, J., Peres, C. A., Henriques, L. M. P., Stouffer, P. C., \& Wunderle, J. M. (2006) The responses of understorey birds to forest fragmentation, logging and wildfires: An Amazonian synthesis. Biological Conservation, 128, 182-192.

Borges, P. A. V., Hortal, J., Gabriel, R., \& Homem, N. (2009) Would species richness estimators change the observed species area relationship? Acta Oecologica, 35, 149156.

Brose, U., Martinez, N. D., \& Williams, R. J. (2003) Estimating species richness: sensitivity to sample coverage and insensitivity to spatial patterns. Ecology, 84, 2364-2377.

Cam, E., Nichols, J. D., Sauer, J. R., \& Hines, J. E. (2002) On the estimation of species richness based on the accumulation of previously unrecorded species. Ecography, 25, 102-108.

Chao, A., Colwell, R. K., Lin, C. W., \& Gotelli, N. J. (2009) Sufficient sampling for asymptotic minimum species richness estimators. Ecology, 90, 1125-1133.

Colwell, R. K. (2004) Estimate S: Statistical estimation of species richness and shared species from samples. Estimate S: Statistical estimation of species richness and shared species from samples, Version 7., User's guide and application published at: http://viceroy.eeb.uconn.edu/estimates.

Develey, P. F. \& Peres, C. A. (2000) Resource seasonality and the structure of mixed species bird flocks in a coastal Atlantic forest of southeastern Brazil. Journal of Tropical Ecology, 16, 33-53.

Esberard, C. E. L. (2006) Effect of sampling of bats during subsequent nights in the same place. Revista Brasileira de Zoologia, 23, 1093-1096.

Ewers, R. M. \& Didham, R. K. (2006) Confounding factors in the detection of species responses to habitat fragmentation. Biological Reviews, 81, 117-142.

Faaborg, J., Arendt, W. J., \& Kaiser, M. S. (1984) Rainfall correlates of bird population fluctuations in a Puerto-Rican dry forest - A 9 year study. Wilson Bulletin, 96, 575593.

Field, S. A., Tyre, A. J., \& Possingham, H. P. (2002) Estimating bird species richness: How should repeat surveys be organized in time? Austral Ecology, 27, 624-629.

Fleishman, E. \& Mac Nally, R. (2003) Distinguishing between signal and noise in faunal responses to environmental change. Global Ecology and Biogeography, 12, 395-402. 
Fleishman, E., Ray, C., Sjogren-Gulve, P., Boggs, C. L., \& Murphy, D. D. (2002) Assessing the roles of patch quality, area, and isolation in predicting metapopulation dynamics. Conservation Biology, 16, 706-716.

Gotelli, N. J. \& Colwell, R. K. (2001) Quantifying biodiversity: procedures and pitfalls in the measurement and comparison of species richness. Ecology Letters, 4, 379-391.

Heck, K. L., Vanbelle, G., \& Simberloff, D. (1975) Explicit calculation of rarefaction diversity measurement and determination of sufficient sample size. Ecology, 56, 1459-1461.

Hubbell, S. P. (2001) The unified neutral theory of biodiversity and biogeography. Princeton University Press, Princeton.

Jenni, L. \& Leuenberger, M. (1996) Capture efficiency of mist nets with comments on their role in the assesment of passerine use. Journal of Field Ornithology, 67, 263274.

Karr, J. R. (1981) Surveying birds with mist nets. Studies in Avian Biology, 6, 62-67.

Link, W. A. \& Sauer, J. R. (2007) Seasonal components of avian population change: joint analysis of two large-scale monitoring programs. Ecology, 88, 49-55.

Link, W. A., Barker, R. J., Sauer, J. R., \& Droege, S. (1994) Within-site variability in surveys of wildlife populations. Ecology, 75, 1097-1108.

Mac Nally, R. (1997) Monitoring forest bird communities for impact assessment: the influence of sampling intensity and spatial scale. Biological Conservation, 82, 355367.

Mac Nally, R. (2002) Improving inference in ecologial research: issues of scope, scale and model validation. Comments on Theoretical Biology, 7, 237-256.

Mac Nally, R., Fleishman, E., \& Murphy, D. D. (2004) Influence of temporal scale of sampling on detection of relationships between invasive plants and the diversity patterns of plants and butterflies. Conservation Biology, 18, 1525-1532.

Mac Nally, R. \& Horrocks, G. (2002) Proportionate spatial sampling and equal-time sampling of mobile animals: A dilemma for inferring areal dependence. Austral Ecology, 27, 405-415.

MacArthur, R. H. \& MacArthur, A. T. (1974) On the use of mist nets for population studies of birds. Proceedings of the National Academy of Sciences, 71, 3230-3233.

Malizia, L. R. (2001) Seasonal fluctuations of birds, fruits, and flowers in a subtropical forest of Argentina. Condor, 103, 45-51.

Manly, B. F. J. (1977) The analysis of trapping records for birds trapped in mist nets. Biometrics, 33, 404-410. 
Moreno, C. E. \& Halffter, G. (2000) Assessing the completeness of bat biodiversity inventories using species accumulation curves. Journal of Applied Ecology, 37, 149158.

Quinlan, S. E. \& Boyd, R. (1976) Mist netting success in relation to weather. North American Bander, 1, 168-170.

R Development Core Team (2007) R: A language and environment for statistical computing. R: A language and environment for statistical computing, Vienna, Austria.

Ralph, J. C. (1976) Standardization of mist net captures for quantification of avian migration. Bird Banding, 47, 44-47.

Remsen, J. V. \& Good, D. A. (1996) Misuse of data from mist-net captures to assess relative abundance in bird populations. Auk, 113, 381-398.

Schooley, R. L. \& Branch, L. C. (2007) Spatial heterogeneity in habitat quality and cross-scale interactions in metapopulations. Ecosystems, 10, 846-853.

Stotz, D., Fitzpatrick, J. W., Parker III, T. A., \& Moskovits, D. K. (1996) Neotropical birds: ecology and conservation. University of Chicago Press, Chicago.

Sutherland, W. J., Newton, I., \& Green, R. E. (2004) Bird ecology and conservation: A handbook of techniques. Oxford University Press, Oxford.

Watson, D. M. (2003) The 'standardized search': An improved way to conduct bird surveys. Austral Ecology, 28, 515-525.

Wiens, J. A. (1992) The ecology of bird communities. Cambridge University Press, Cambridge.

Zar, J. H. (1996) Biostatistical Analysis. Prentice Hall International, London. 
Table 1. Pairwise correlations among sites between surveys of 170 net-hours and data pooled for surveys of 340 net-hours, based on Pearson correlation for species richness and Mantel test performed on a Bray-Curtis dissimilarity matrix for species composition. (Surveys: A - Dry Season 2005, B - Wet Season 2006, C - Dry Season 2006 and D - Wet Season 2007). ${ }^{*} P<0 \cdot 05$, ** $P<0 \cdot 01$.

\begin{tabular}{llll}
\hline Survey (170 net-hours ) & A & B & C \\
\hline Species richness & & & \\
B & -0.02 & & \\
C & 0.05 & $0.38^{*}$ & \\
D & 0.30 & 0.07 & $0.47^{*}$
\end{tabular}

Community composition

B

$0.21^{* *}$

C $0.26 * *$

$0.16^{*}$

$\mathrm{D}$

$0.23 * *$

$0.22 * * \quad 0.34 * *$

\begin{tabular}{ccrr}
\hline Survey (340 net-hours ) & C + D & B + D & B + C \\
\hline Species richness & & & \\
A + B & $0.51^{* *}$ & & \\
A + C & & $0.67^{* *}$ & \\
A + D & & & $0.43^{*}$
\end{tabular}

Community composition

$\begin{array}{lll}\mathrm{A}+\mathrm{B} & 0.39^{* *} & \\ \mathrm{~A}+\mathrm{C} & & 0.43^{* *} \\ \mathrm{~A}+\mathrm{D} & & \\ \end{array}$




\section{Figure Legends}

Figure 1 - Annual temperature and rainfall variation in the study region (www.cpa.unicamp.br). Bars represent changes in average monthly temperatures $\left({ }^{\circ} \mathrm{C}\right.$ ) while dots show the variation in average rainfall (mm).

Figure 2 - Species accumulation curves for each site showing in (a) the total number of species captured with increasing sampling effort (net-hours) and (b) number of understory-obligate species with increasing sampling effort. None of the sites showed signs of reaching an asymptote that would indicate that all species present had been recorded.

Figure 3 - Variation in bird capture rates through the day for (a) the full dataset, (b) the wet season and (c) the dry season. Thick lines represent the median, boxes represent the interquartile range and whiskers represent minimum and maximum values. Presence of capital letters indicate similarities among levels, such as: " $C$ " indicates the levels with a significant increase in captures when compared to the levels with "B”, which in turn had a significant increase in captures when compared to the level with "A", etc.

Figure 4 - Variation in bird captures among sequential 170 net-hour surveys (Survey A - Dry Season 2005, Survey B - Wet Season 2006, Survey C - Dry Season 2006, Survey D - Wet Season 2007), for (a) total captures (captures of new individuals plus recaptures), (b) captures of new individuals, (c) recaptures. Presence of capital letters indicate similarities among levels, such as: “B” indicates the levels with a significant increase in captures when compared to the levels with "A", which in turn had a significant increase in captures when compared to the level with no letters 
Figure 5 - Results of simple linear regressions for analyses of species richness against forest cover (left-hand panels) and patch size (right-hand panels) obtained using data from 22 sites. In each panel, $P$-values are represented by asterisks and filled dots represent the slope values ( $\pm 1 \mathrm{SE}$ ) obtained for each analysis. A horizontal dashed line represents $P=0.05$. The slope values did not change significantly when birds were sampled at just one time of day, one season, one survey (Survey: A - Dry Season 2005, B - Wet Season 2006, C - Dry Season 2006, D - Wet Season 2007) or with progressively greater sampling effort. 
Figure 1

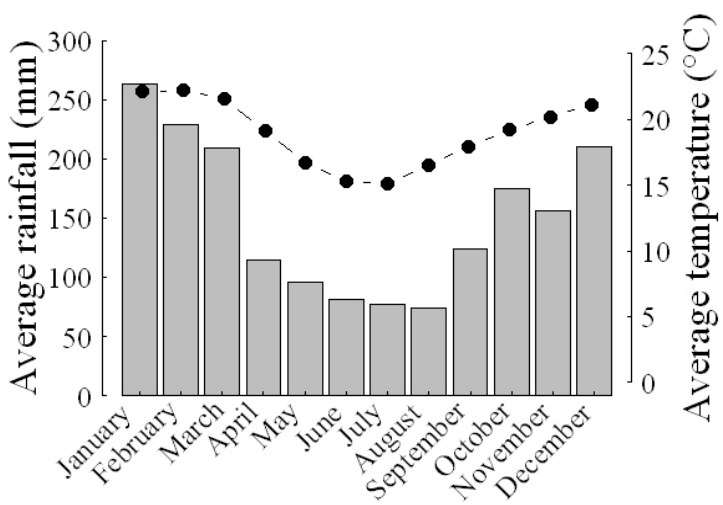


Figure 2
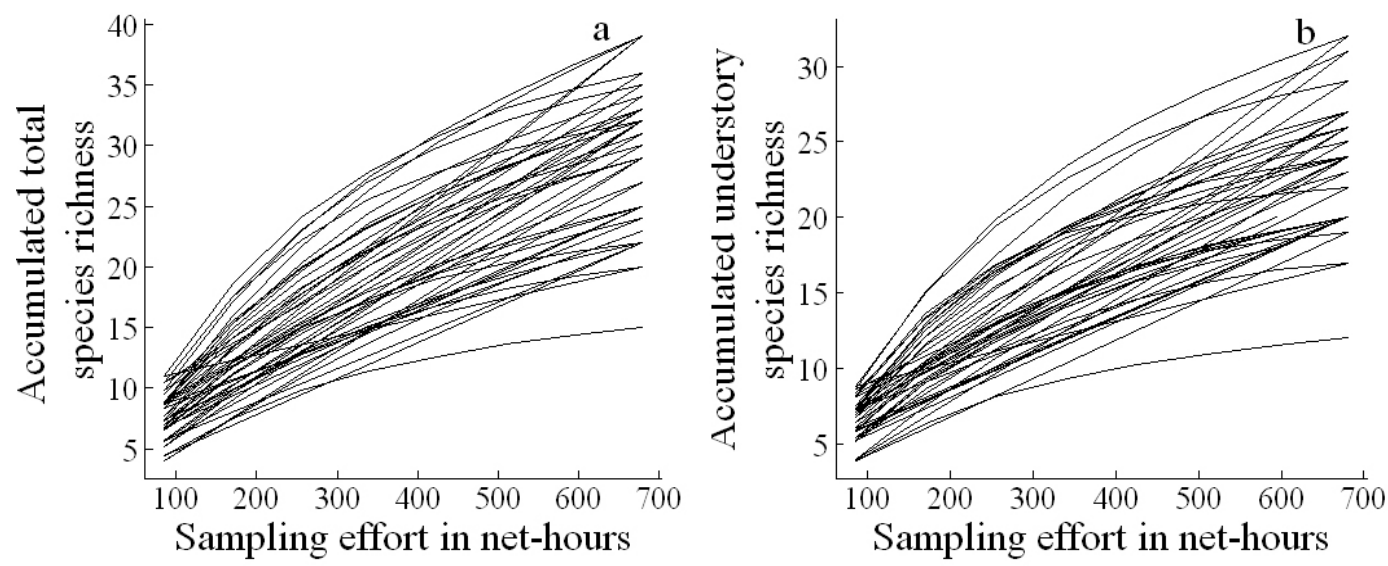
Figure 3
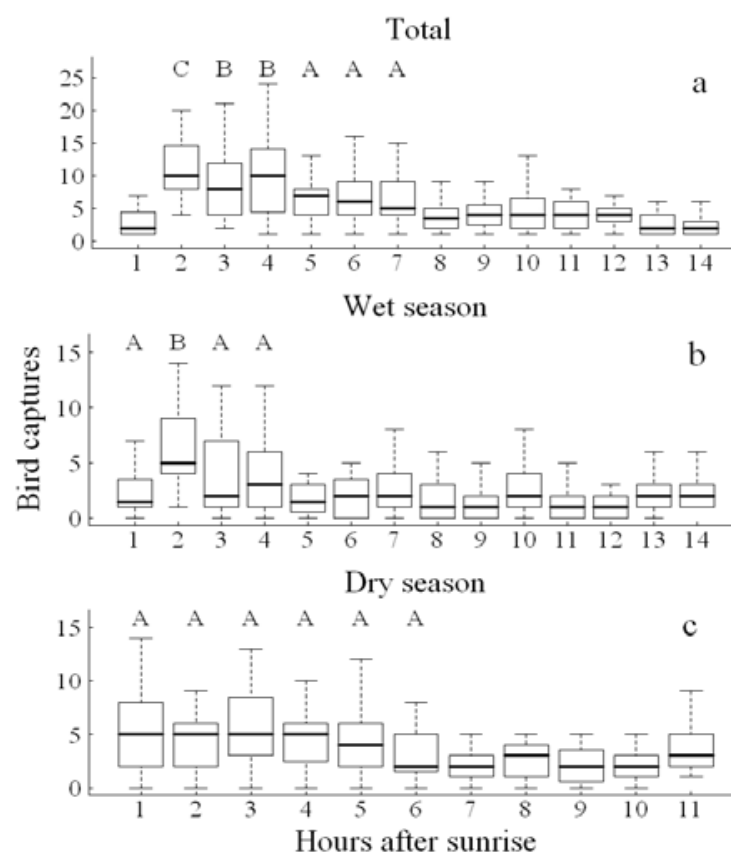
Figure 4
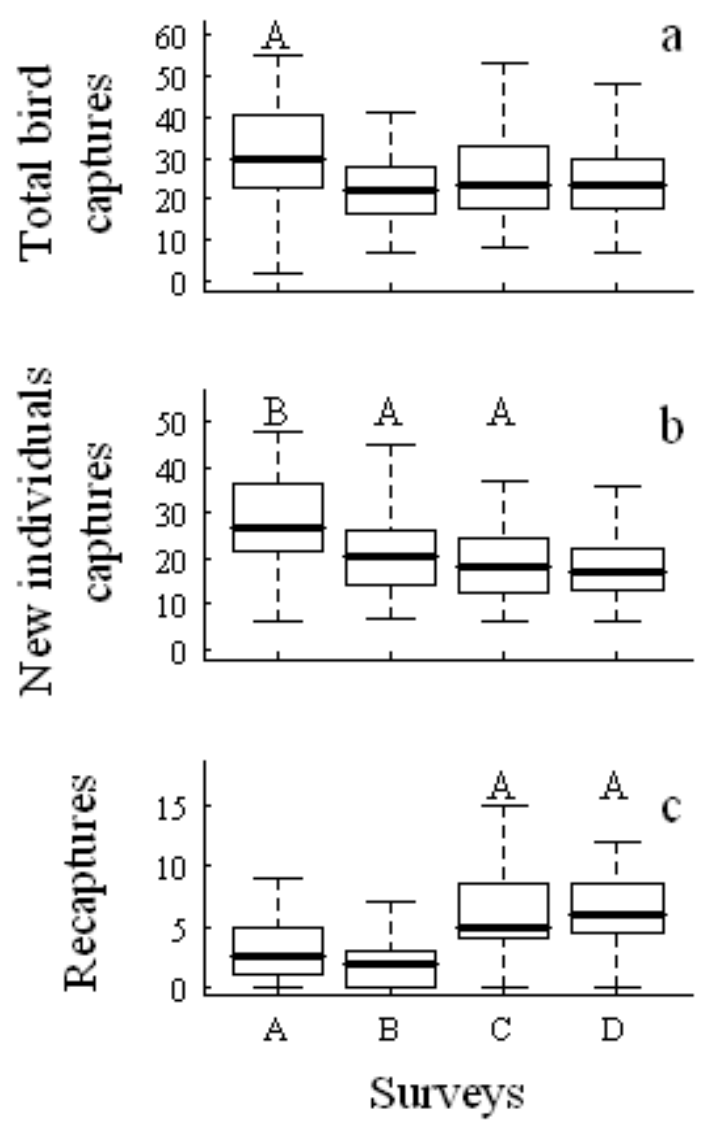
Figure 5

Forest cover analyses

Patch size analyses
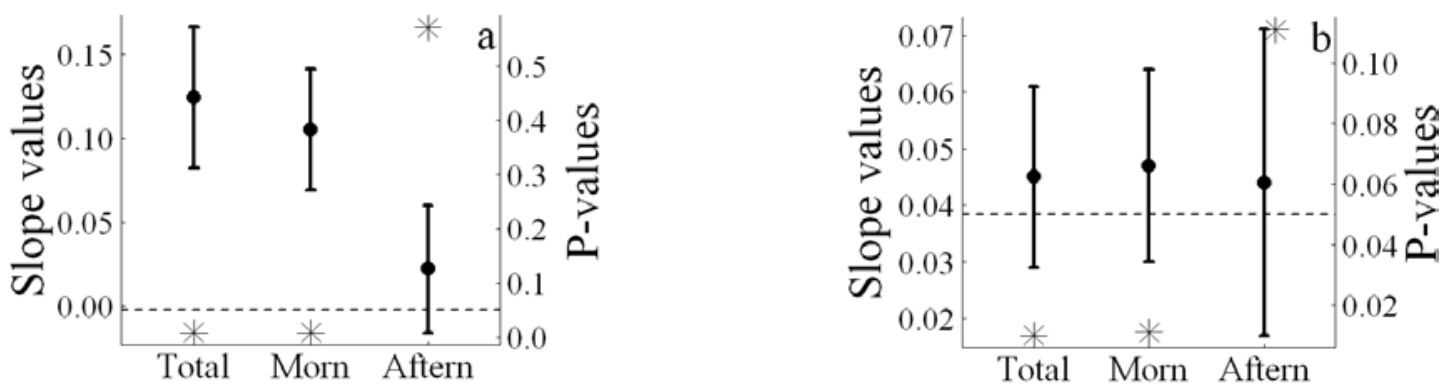

Daily periods
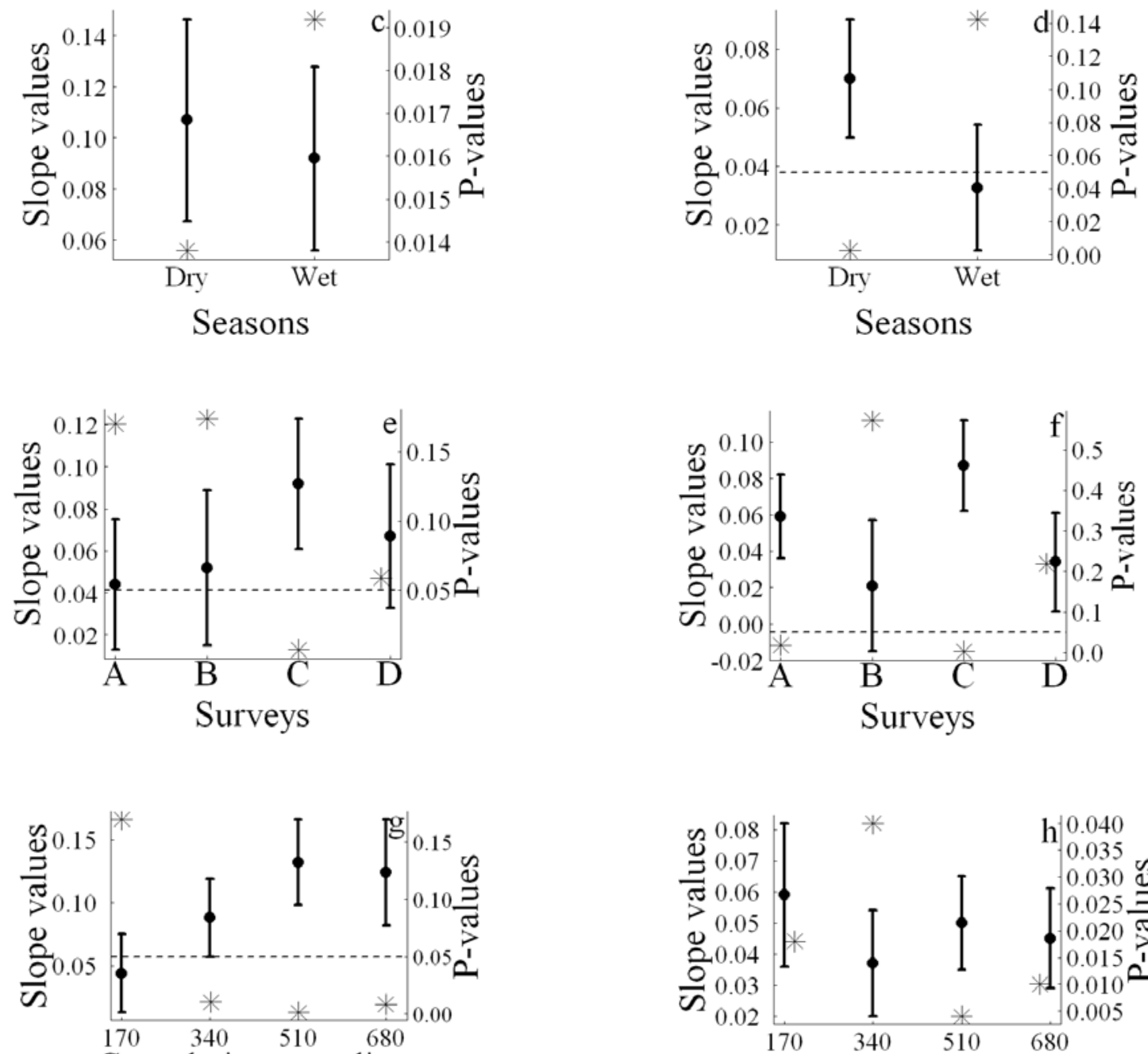

Cumulative sampling (net/hours)

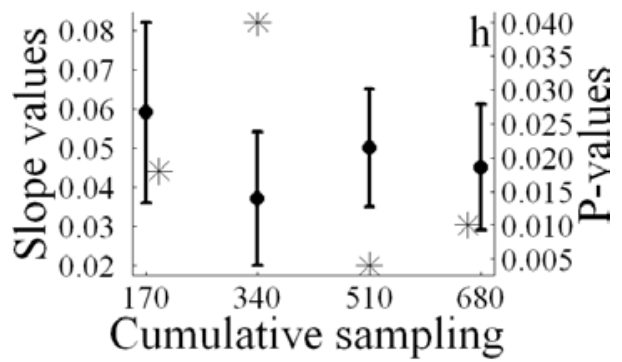
(net/hours) 


\section{5 - Supplementary material}

\section{Estimators of species richness}

Brose et al. (2003) proposed a framework to help deciding which nonparametric estimator of richness is most appropriate for each dataset. These authors proposed two possible pathways depending on the observed sample coverage. In path1, the true richness is calculated by a range of estimators (e.g. Jackknife, ACE, ICE), which are then used to estimate the sample coverage; and finally, the most appropriate estimator is chosen depending on the sample coverage of the dataset (see Fig. 6, Brose et al., 2003). In path 2, the most accurate estimator is solely chosen based on the community evenness. We used path 1, recommended by Brose et al. (2003), to assess which would be the most appropriate estimator for our dataset. By using a range of estimators (ACE, ICE, Chao 1, Chao2, Jackknife 1, Jackknife 2), we calculated that the most appropriate estimator for our dataset would be Jackknife 2, as our sample coverage was, on average, $72 \%$ of the true richness.

\section{Patch size affecting estimator biases}

In a second step, we regressed the species richness estimated using Jackknife 2 against the observed species richness. The relationship was strong and positive $\left(R^{2}=0.674\right.$, Slope $\left.=1.548, F_{1,20}=41.35, P<0.001\right)$. Then we regressed the residuals from this relationship against patch size (log-transformed). This yielded a weak, negative relationship $\left(R^{2}=0.148\right.$, Slope $=-1,448, F_{1,20}=3.47, P=0.077$ ), showing that there was a tendency that in small patches, where observed richness and capture rate was low, the estimated species richness (Jackknife 2) was comparable to, or higher than, that of large patches, where observed richness and capture rate were high. 
To further support the idea that small patches had a lower carrying capacity, we also conducted two linear models, one to test the effect of patch size on capture rate and another to test the effect of patch size on recapture rate. In the first model we used Poisson errors (with a quasipoisson correction for overdispersion) and found that patch size was positively related to capture rates $\left(R^{2}=0.268\right.$, Slope $\left.=0.777, P=0.012\right)$. In the second model we used binomial errors to account for the fact that recapture rate would be higher in patches with high capture rate We found that patch size was negatively related to recapture rate $\left(R^{2}=0.423\right.$, Slope $\left.=-0.114, P=0.001\right)$. These results, together with the fact that we had a uniform sampling effort at each site, illustrate how the fact that we captured less individuals in smaller patches is not related to changes in sample coverage, but is instead due to biological differences among patches (i.e. carrying capacity).

\section{References}

Brose, U., Martinez, N. D., \& Williams, R. J. (2003) Estimating species richness: sensitivity to sample coverage and insensitivity to spatial patterns. Ecology, 84, 23642377. 
Table S1 - Values of patch size (ha) for each site, sample coverage for each site in comparison to the Jackknife 2 non-parametric estimator and standard deviation of sample coverage among surveys A, B, C and D.

\begin{tabular}{l|rrr} 
Patch & \multicolumn{1}{c}{ Patch } & Sample & \multicolumn{1}{c}{ SD } \\
ID & \multicolumn{1}{c}{ Size } & Coverage & \\
\hline ID1 & 17.72 & 62.83 & 2.99 \\
ID2 & 3.00 & 53.18 & 4.86 \\
ID3 & 4.25 & 63.97 & 4.04 \\
ID4 & 24.50 & 85.33 & 2.38 \\
ID5 & 6600.00 & 78.58 & 1.41 \\
ID6 & 14800.00 & 76.02 & 6.38 \\
ID7 & 103.54 & 62.05 & 3.42 \\
ID8 & 3.73 & 66.67 & 1.89 \\
ID9 & 16.70 & 63.04 & 3.86 \\
ID10 & 4.10 & 67.36 & 2.99 \\
ID11 & 21.22 & 60.08 & 3.32 \\
ID12 & 3.61 & 43.49 & 3.40 \\
ID13 & 27.90 & 63.33 & 1.41 \\
ID14 & 3.46 & 73.92 & 4.79 \\
ID15 & 14.40 & 62.88 & 3.65 \\
ID16 & 92.00 & 57.37 & 4.20 \\
ID17 & 145.35 & 60.95 & 3.70 \\
ID18 & 29.00 & 53.27 & 4.79 \\
ID19 & 6600.00 & 76.45 & 8.37 \\
ID20 & 14800.00 & 61.18 & 2.38 \\
ID21 & 132.29 & 80.73 & 4.19 \\
ID22 & 3.10 & 72.99 & 3.74
\end{tabular}




\section{Capítulo 6}

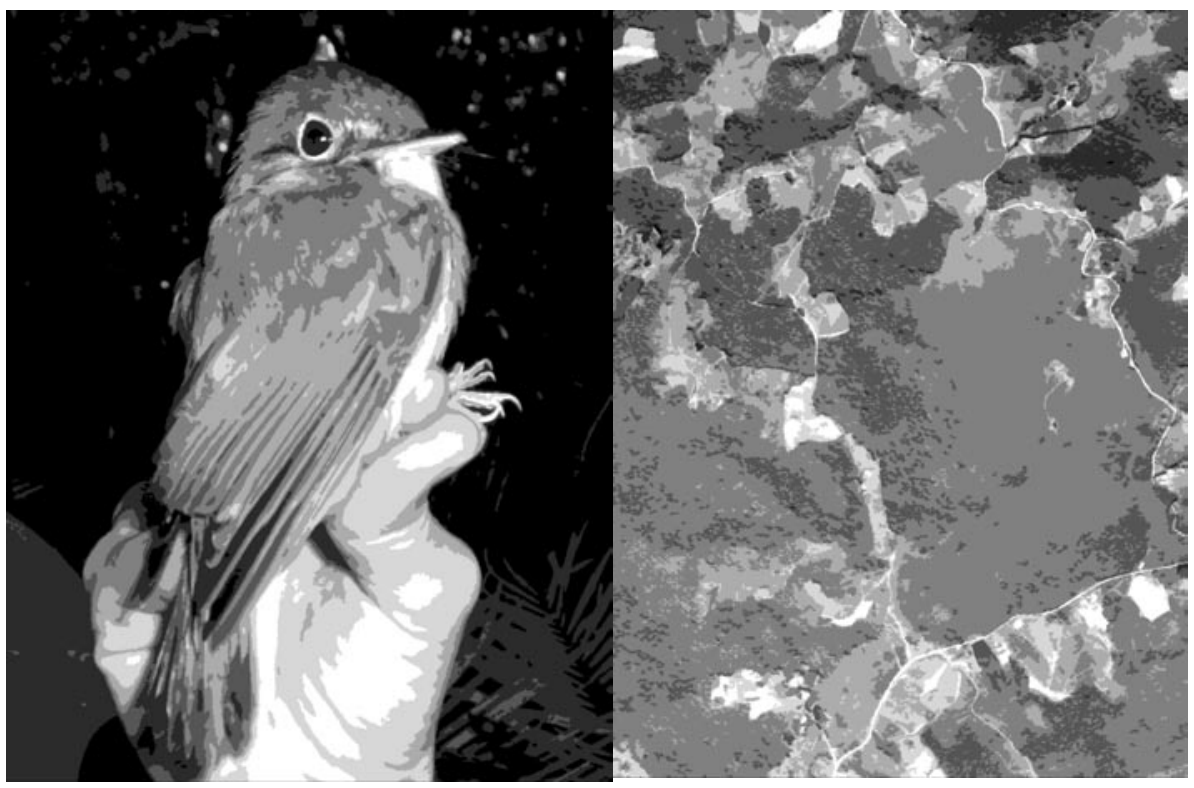




\section{Capítulo 6}

Comparing the use of species and landscape measures as indicators of ecological integrity

Cristina BANKS-LEITE, Robert M. EWERS, Valerie KAPOS, Alexandre C.

MARTENSEN \& Jean Paul METZGER 


\section{Resumo}

O uso de indicadores para avaliar e monitorar o status e valor de conservação de uma dada área tem sido criticado em diversas instâncias, porém continua sendo bastante utilizado uma vez que ainda não foi encontrada solução melhor. Entre as várias possibilidades do uso de indicadores, existem duas estratégias que se sobressaem: o uso de espécies indicadoras e o uso de métricas da paisagem como indicadores. Aqui, tivemos o objetivo de contrastar as vantagens e desvantagens destas duas estratégias de uso de indicadores: (1) ao comparar eficácia de espécies e métricas da paisagem em duas escalas distintas, escala da paisagem vs. regional; (2) avaliar como mudanças na resolução dos dados (abundância vs. presença-ausência e 10m vs. 30m de pixel da imagem) poderiam afetar estes resultados; e (3) quantificar o grau em que indicadores gerados para uma área, ou escala, a podem ser aplicados em contextos distintos. Para responder estas questões, nós usamos um banco de dados com mais de 7,000 aves capturadas por redes de neblina em 65 sítios amostrais localizados em seis paisagens de 10,000 ha cada na Floresta Atlântica do Estado de São Paulo (três paisagens fragmentadas com $10 \%$, $30 \%$ e $50 \%$ de cobertura florestal remanescente, e três controles: paisagens contínuas com mais de 90\% de cobertura florestal). Nós comparamos a eficácia destas estratégias como indicadores de mudanças na integridade da comunidade, aqui definida como a diferença da composição da comunidade de aves entre fragmentos e áreas controle. Apesar de na escala regional, espécies indicadoras apresentarem resultados mais robustos que os obtidos com métricas indicadoras, este padrão foi invertido na escala da paisagem, onde métricas da paisagem geraram resultados mais fortes e menos variáveis que o de espécies, independentemente da resolução dos dados. Com uma combinação de 10 métricas da paisagem, foi possível explicar até 99\% da variação da composição da comunidade. Indicadores baseados em métricas da paisagem também apresentaram maior eficiência quando aplicados em outros contextos. A perda de poder explicativo no uso de métricas indicadoras selecionadas como boas indicadoras para uma paisagem e aplicadas em outras paisagens variou em torno de 5 a 10\%, enquanto que a perda no poder explicativo da aplicação de espécies indicadoras em outras áreas foi de 25\%. Nós discutimos estes resultados no âmbito de questões de manejo e conservação atuais, e propomos que o uso de métricas indicadoras é a estratégia mais simples, mais barata e mais eficiente na identificação de áreas com comunidades integras. 


\begin{abstract}
The use of indicators for assessing and monitoring the status, condition or conservation value of a given landscape has been attacked on several grounds, but nonetheless retains appeal as no more parsimonious approach exists. Among the many variants, two indicator strategies stand out: the use of indicator species or of measures of landscape structure. Here, our goals were to contrast the advantages and disadvantages of these two strategies by: (1) comparing the effectiveness of species-based and structural-based indicators at regional vs. landscape spatial scales; (2) assessing how changes in data resolution (abundance vs. presence-absence data for indicator species, and coarse vs. fine pixel size for structural indicators) would affect these results; and (3) quantifying the degree to which indicators that are generated in one landscape can be transferred to additional landscapes. We used data from more than 7000 birds captured using mist nets in 65 sites from six landscapes in the Atlantic Forest of Brazil (three fragmented landscapes, $10 \%$, $30 \%$ and $50 \%$ of forest cover and three continuous landscapes with more than $90 \%$ forest cover). We assessed changes in community integrity, which we defined as deviations in bird community composition from control areas. Our results showed that at the regional scale, indicator species provide more robust predictions of community integrity than structural indicators. However, this pattern was inverted at the landscape scale; structural indicators performed better and were less variable than species, regardless of data resolution. A combination of 10 landscape measures explained up to $99 \%$ of the variation in community integrity. Structural indicators were also more transferable. Irrespective of data resolution, the loss in explanatory power from applying structural indicators obtained from one landscape to additional landscapes varied from 5 to $10 \%$, while indicator species lost an average of $25 \%$ of explanatory power. We discuss these results in the light of current conservation and management concerns and propose that landscape structural indicators might be the best, simplest to implement, and cheapest strategy for identifying with high community integrity.
\end{abstract}

Key-words: Atlantic Forest, biodiversity indicators, birds, habitat fragmentation, habitat loss, lansdcape metrics, surrogates, Umbrella Index

Running head: SPECIES VS. STRUCTURAL-BASED INDICATORS 


\section{1 - Introduction}

The interest in the use of biodiversity indicators has been rising rapidly for more than a decade. Since 2002, when 188 government Parties to the Convention on Biological Diversity agreed "to achieve by 2010 a significant reduction of the current rate of biodiversity loss” and to use indicators to monitor progress towards this target (Mace \& Baillie, 2007), the study of biodiversity indicators has attracted considerable attention (e.g. Kati et al., 2009; Mattfeldt et al., 2009; Michel \& Winter, 2009; Mawdsley \& O'Malley, 2009; Franco et al., 2009). However, for every study supporting the use of indicators (e.g. Manne \& Williams, 2003; Mac Nally \& Fleishman, 2004; Bubb et al., 2006), there is probably an equivalent number of studies arguing against their widespread use (e.g. Lawton et al., 1998; Andelman \& Fagan, 2000; Caro, 2003). In fact, the controversy around biodiversity indicators is so large that it has been suggested that surrogates are too context-specific to be reliable and that their use as a conservation strategy is limited (Hess et al., 2006).

The reason why biodiversity indicators do not uniformly work as an efficient strategy for representing biological conditions has both methodological and biological roots. Indicator species are often selected for ecologically unsound bases such as being appealing to the general public, and having a large area requirement or body size. These traits do not inevitably confer on the species that possess them a high correlation with local diversity or extinction threat (Hockey \& Curtis, 2009). As a result, the use of species selected for these reasons is frequently no more efficient than employing a random selection of species (Andelman \& Fagan, 2000; Caro, 2003; Grenyer et al., 2006; Roth \& Weber, 2008; Cabeza et al., 2008). Other methodological issues that may affect the efficiency of the indicator species strategy, and the comparability of the results across studies, are the lack of standardisation of the statistical methods used to 
select indicator species, variation in data resolution among studies that select indicator species, the spatial and temporal scale of the sampling design that is used for the selection of indicators (Weaver, 1995; Thomson et al., 2005; Grenyer et al., 2006; Billeter et al., 2008; Cabeza et al., 2008) and the region and extent of study area (Fleishman et al., 2002; Hess et al., 2006).

When selecting indicators, the usual goal is to maximise the spatial correlation between the occurrence of a given species with local species richness of one or several taxa, but this association has proven difficult to find (Lawton et al., 1998; Su et al., 2004). There is now mounting evidence showing that species richness holds little biological information and is highly sensitive to differences in sampling effort and to the invasion of matrix species, which have low conservation importance (Gotelli \& Colwell, 2001; Su et al., 2004; Barlow et al., 2007). In fact, when assessing the effects of tropical forest degradation on multiple taxa, several studies have shown that it is more important to explicitly consider patterns of community turnover rather than species richness (Barlow et al., 2007; Basset et al., 2008).

An approach that has received less attention than the use of indicator species is the use of structural-based indicators such as landscape metrics, or other environmental variables, to assess changes in biodiversity or ecological integrity (Noss, 1999; Lindenmayer et al., 2002a; Faith, 2003). The use of landscape metrics has distinct methodological advantages in that the data is relatively easy to obtain via satellite imagery (Turner et al., 2003), and that there are easy to use freeware programs available for quantifying landscape metrics such as the widely used Fragstats (McGarigal \& Marks, 1995). However, the use of landscape metrics also has a numbers of drawbacks. For example, the link between many landscape metrics and on the ground measures of biological condition are often not clear, and species with different life-histories respond 
differently to the same spatial patterns of habitat (Andrén, 1994; Noss, 1999; Lindenmayer et al., 2002a; Fahrig, 2003; Ewers \& Didham, 2006). Consequently, structural-based indicators may suffer from the same problems cited for species-based indicators and, as with the use of indicator species, structural indicators may not provide better results than chance alone (Araujo et al., 2001).

In this study, we compared the relative efficacy of species-based and structuralbased indicators for detecting changes in the integrity of bird communities, defined here as changes in community composition caused by anthropogenic disturbances. We used birds because they have been shown to be good indicators of ecological changes (Gardner et al., 2008) and because there is considerable knowledge of their responses to habitat loss and fragmentation for many areas of the world (Lindenmayer et al., 2002b; Billeter et al., 2008; Peters et al., 2008; Martensen et al., 2008; Ranganathan et al., 2008). Our goals were to (1) compare whether species or landscape structural indicators was more efficient in identifying sites with the highest community integrity at a regional and landscape scale; (2) assess how data resolution alters the efficiency of the two types of indicators; and (3) assess which indicator has the highest transferability, i.e. the ability of indicators generated in one area to successfully predict biological patterns in other areas and at different spatial scales.

\section{2 - Methods}

\section{Study area}

The study was conducted in the Atlantic Plateau of the State of São Paulo, Brazil. The original vegetation in the area is classified as lower montane Atlantic forest, the altitude ranges from 700 to $1100 \mathrm{~m}$ above sea level, the mean annual temperature varies from 15 
to $22^{\circ} \mathrm{C}$ and annual rainfall varies from 1,350 to over 2,000 mm (www.cpa.unicamp.br). Sampling was conducted in six 10,000-ha landscapes, three of which were fragmented but varied in the total amount of forest cover (10\%, 30\% and 50\%) while the remaining three had near-continuous forest cover (> 90\%) (Capítulo 1, Fig. 1). The fragmented landscapes were mainly composed of native vegetation in various successional stages (from 20 to over 100 years), croplands, pastures and plantations of Eucalyptus spp. The continuous landscapes, each paired with a nearby fragmented landscape (distance among landscape pairs ranged from 2 to $3 \mathrm{~km}$ ), were composed of native vegetation but varied in successional age and in the level of historical human impact. However, for these analyses we consider all sites sampled in the unfragmented landscapes as control areas.

We sampled a total of 12 sites in continuous forest (four sites in each control landscape) and 53 patches in the fragmented landscapes; 17 patches in the $10 \%$ forest cover landscape (hereafter 10\% FC landscape), 17 patches in the 30\% FC landscape, and 19 patches in the 50\% FC landscape. Forest patches were selected to reflect the natural variation in patch size and connectivity present in the fragmented landscapes. Thus in each landscape, we sampled in seven small patches ranging from 2 to 9 ha, seven to eight medium-sized patches from 12 to 40 ha, and three or four large patches of 45 to 150 ha. A stratified selection procedure was performed so that in each fragment size class, half of the patches had low values of the proximity index (e.g. proximity to other patches) and half had high proximity levels (McGarigal \& Marks, 1995). Fragments were composed of a mosaic of different forest successional stages, with most fragments in a medium successional stage ( $\sim 40$ to 60 years). 


\section{Bird sampling}

The understorey bird community was sampled using 10 mist nets (12 m length, $2.5 \mathrm{~m}$ high, $31 \mathrm{~mm}$ mesh) positioned in a single line that was as straight as possible and followed the slope contour. All 65 sites were sampled twice in the dry season (austral winter) and twice in the wet season (austral summer) to control for seasonal differences, and each site was sampled for an average of 637 net-hours (SD = 77). Nets were checked every hour and closed whenever there was a heavy rain. All captured birds were identified to species in the field and marked with a numbered aluminum band provided by Center of Research for Conservation of Wild Birds (CEMAVE - IBAMA) and released in the vicinity. Thus, between March 2001 and March 2007 we performed in total over 41,000 net-hours. There were minor differences in sampling protocol and across landscapes (Supp. Mat.), but there is no reason to expect that these differences would generate biased estimates of bird community composition. Similarly, there was a small amount of variation in sampling effort among landscapes (Supp. Mat.), which was statistically controlled for in all analyses.

\section{Landscape metrics}

Land cover for all landscapes was classified from Spot 5 images from 2005 with $10 \mathrm{~m}$ resolution. Landscape metrics were calculated using Fragstats 3.3 (McGarigal \& Marks, 1995) and were selected to represent environmental variables that are known to affect birds such as patch area, edge effects, connectivity and the proportion of forest cover around sampling points (Villard et al., 1999; Fletcher, 2005; Martensen et al., 2008). Thus we calculated the size, perimeter and shape of patches, the core area of patches using edge penetration distances of 20, 50 and 100 m (following Laurance, 2004), contiguity index, proximity index in the range of 20, 50 and 100 m (following Awade \& 
Metzger, 2008) and the proportion of forest in circles of radii of 300, 500 and $800 \mathrm{~m}$ around sampling points (following Boscolo, 2007).

Statistical Analysis

All analyses were conducted using R v2.7.1 (R Development Core Team, 2008).

\section{Assessing bird community integrity}

To assess changes in bird community integrity, we used bird community composition observed in the control sites as a reference condition and quantified the extent to which the species composition in fragments deviated from the reference sites. To obtain the most rigorous representation of variation in community composition, we inspected the scores from all combinations of five dissimilarity indices and three ordination methods that fit well to biological data (Legendre \& Legendre, 1998) (Supp. Mat.). The combination that produced the best results was the Principal Coordinate Analyses (PCoA) performed on a Bray-Curtis dissimilarity matrix (Supp. Mat., Fig. S1), so this combination was retained for all analyses.

Deviations in community composition from the reference condition can be measured as Euclidean distances in the multidimensional space from each patch to the control sites. But previous inspection of the data showed that there was a strong gradient in community composition from the control areas to the small isolated patches of the 10\% FC landscape in the first PCoA axis (Fig. 2) and an uninformative second axis, revealed by a distinctive horseshoe effect (Fig. S1); therefore we only used the first PCoA axis. Because all control sites were grouped at one end of the axis and we only used one ordination axis, we did not have to measure the Euclidean distance from the 
reference condition to each patch to calculate the deviations in community composition (i.e. community integrity), instead we used the original scores of the PCoA axis.

Although, the control sites were included in all ordinations to ensure that communities in forest fragments would be positioned relative to reference conditions in multidimensional space, all further analyses were based solely on the ordination scores from fragment communities.

\section{$\underline{\text { Selecting indicator species }}$}

We used the Umbrella Index (UI) developed by Fleishman et al. (2000) to select the set of indicator species whose conservation likely confers protection to other co-occurring species (paths 1 to 8 on Fig. 1). This index has two major advantages: (1) it avoids ambiguity by defining potential umbrella species in an ecological and quantitative framework, and (2) the utility of this index has been demonstrated a number of times and for various taxa including plants, butterflies and birds (Fleishman et al., 2003; Betrus et al., 2005; Bried et al., 2007).

The UI of each species was calculated as the sum of its medium rarity (1-|0.5- $P \mid$, where $P$ is the proportional occurrence), mean percentage of co-occurring species and disturbance sensitivity (Fleishman et al., 2000). The proportional occurrence $(P)$ of each species is calculated by summing the number of sites in which the species is present and dividing by the total number of sites sampled. The mean percentage of co-occurring species is calculated by averaging the species richness $\left(S_{\text {site }}-1\right)$ in each site from which the target species was recorded and dividing by the highest recorded species richness among all sites $\left(S_{\max }-1\right)$. To assess species' sensitivity to human disturbance, Fleishman et al. (2000; 2003) suggested using life history biological traits, such as nesting and feeding behaviour of birds. However, such detailed information is not 
available for most birds in this region, so we used an alternative approach to estimate species' sensitivity. We calculated the correlation between the abundance of each bird species in forest fragments and the gradient of community composition, as represented by the ordination scores. To avoid circularity in these estimates, for each correlation we ran a separate ordination including all recorded species but the one being tested (i.e. the relationship between species $i$ and an ordination performed on a matrix containing all species except i). Because species abundance does not regularly follow normal distributions, we used Generalised Linear Models (GLM) using Poisson errors to calculate the treatment deviance relative to the null deviance of the model (analogous to the $R^{2}$ measure in regression models and hereafter referred to as 'explained deviance'). Differences in sampling effort among sites were controlled by dividing the species abundances per site by the sampling effort of each given site. We used explained deviance as the measure of species' sensitivity to human disturbance for calculating the UI. All species that had an UI greater than the mean plus 1 standard deviation of the distribution of UI values were included in the set of indicator species (following Fleishman et al. 2000).

\section{$\underline{\text { Selecting landscape structural indicators }}$}

Because of high correlations among the measured landscape metrics (Table S1), we performed a Principal Components Analysis (PCA) to obtain 13 uncorrelated axes (one less than the number of metrics, $N$, that were calculated) that represented all the variation in the landscape metrics. PCA axes were obtained by log-transforming all variables which incorporated a measure of patch area, and scaling all $N$ metrics to have a zero mean and unit variance. Although it is often suggested that only PCA axes with a eigenvalue larger than 1 should be statistically interpreted (Legendre \& Legendre, 
1998), we retained all $N-1$ PCA axes because reducing the amount of environmental variation can limit species representation (Faith, 2003), and because preliminary data analysis showed that all axes were, at some point, correlated with changes in community composition and that their exclusion lead to a significant loss in explanatory power. To select a final set of structural indicators (paths 9 to 16, Fig. 1), we used backwards stepwise regression, in which the PCoA axis of community composition was the response variable and the set of PCA axes, representing changes in landscape metrics, were the explanatory variables. Models were compared with AIC (Burnham \& Anderson, 1998).

\section{Changing spatial scale and data resolution}

To estimate the potential effect of the spatial scale at which indicators are chosen and the resolution of the data that is used to select indicators, on the ability of the final indicator set to represent changes in community integrity, we repeated our analyses multiple times (Fig. 1).

First, we compared the sensitivity of species vs. landscape structural indicators by selecting indicators using data from two different scales: (1) the regional scale, using all 53 patches in a single analysis, and (2) separately for each landscape. For the landscape scale, we performed a separate ordination for each of the three fragmented landscapes, using the paired control landscapes as the reference sites from which community composition was measured.

Second, we assessed the impact of data resolution on the sensitivity of indicators. To determine how changes in data resolution would alter the sensitivity of species-based indicators, we collapsed the matrix of species abundances into presenceabsence only, resulting in a loss of ecological information about the relative abundances 
of species. For consistency, the use of presence-absence data required us to recalculate the measure of disturbance sensitivity in the UI, which was previously calculated by correlating species abundances with an ordination performed on an abundance matrix. For this analysis, we re-calculated disturbance sensitivity by modelling species presence-absence as the response variable and an ordination performed on presenceabsence data as the explanatory variable, using GLM models with binomial errors.

To assess how changes in data resolution would alter the efficiency of landscape structural indicators, we degraded the resolution of the 10-m pixel map from which landscape metrics were calculated into a 30-m pixel map, similarly to a Landsat image. Because of the changes in resolution, two out of the 13 landscape metrics could not be calculated in 30-m pixel images, thus we only obtained 11 PCA axes.

$\underline{\text { Testing for indicator transferability across landscapes and across scales }}$ Indicators that are highly transferable are those that can be selected from one location but are sensitive to changes in community integrity in other locations; in other words, we evaluated the efficiency of exogenous indicators (an indicator selected from one dataset and tested against one or more independent datasets) rather than endogenous indicators (an indicator selected from, and tested against, a single dataset). Thus, we estimated indicator transferability across landscapes by using the set of species and structural-based indicators selected from one landscape as the predictors of the changes in community integrity of the other landscapes. This test treats the indicators as exogenous, and we calculated the explanatory power of these various exogenous indicators with a multiple linear regression. When assessing the transferability of structural-based indicators, we performed a single PCA with all 53 patches to ensure 
that all ordination axes represented the same gradient of spatial patterning in all landscapes, and then later sub-divided the PCA axes by landscape.

The same procedure described above was used to test for indicator transferability across scales. Indicators that were selected from the regional scale dataset were applied to each of the three landscape scale datasets, and indicators selected from the three landscape scale datasets were applied to the regional scale dataset.

\section{Comparing the sensitivity of indicators to changes in community integrity}

Once the best subsets of indicators species and structural indicators had been selected, we assessed their ability to represent changes in community integrity using multiple linear regressions (GLM with Gaussian errors), in paths $a_{i j}$ to $d_{i j}$. The response variable in these regressions was deviations in community composition from the reference sites, and the explanatory variables were the chosen subset of either species-based or structural-based indicators (Fig. 1). Because it is more practical to use presence-absence rather than measures of species abundance as indicators in the field, whenever we tested the efficiency of indicator species we used the presence or absence of those species as the explanatory variables. Comparison of results where abundance rather than presenceabsence was used showed non-significant differences, so this decision did not alter any of the conclusions arising from the analyses. Measures of model fit from the multiple regressions were taken to indicate the relative sensitivity of the two indicator strategies to changes in community integrity.

We fitted GLMs for each combination of the indicator strategy (species vs. structural), data resolution (high vs. low), spatial scale (local vs. regional), and data transferability (multiple landscape and cross-scale comparisons). We took the model $R^{2}$ as a measure of the explanatory power with which a given indicator set was able to 
reflect changes in community integrity, and used this measure to compare the differences in sensitivity of the different combinations. However, we could not perform robust hypothesis tests because the total number of comparisons was low. Instead, we report effect sizes $(d)$, a measure of the magnitude of a difference (Cohen, 1988). Following Rosenthal \& Rosnow (1991), we computed $d$ from the value of the $t$-test of the differences between two means $(d=2 t / \sqrt{ } v)$, where $v$ is the degrees of freedom of the $t$-test, although we here used a paired $t$-test in which the comparisons of indicator sensitivity were nested by landscape. For instance, to assess differences in the sensitivity of indicator species when modifying data resolution, we calculated the $t$ value of the difference in $R^{2}\left[\left(a_{11}-b_{11}\right)+\left(a_{22}-b_{22}\right)+\left(a_{33}-b_{33}\right)+\left(a_{44}-b_{44}\right)\right]$ (Fig. 1$)$, from which calculated the effect size $d$. Effect sizes were interpreted in terms of the average percentile standing of one group mean relative to the other, in which an effect size larger than 1.7 shows that the mean of one group is at the 95.5 percentile of the other group $($ similar to a one-side $P$-value $=0.05)($ Cohen, 1988).

Comparisons of species vs. structural-based indicators and of high vs. low resolution data within an indicator strategy were performed using the observed $R^{2}$ of the regression models. But we took a different approach to compare the transferability potential and the effect of data resolution between species and structural-based indicators. We subtracted the $R^{2}$ of models built with exogenous indicators from the $R^{2}$ of models built with endogenous indicators and then compared this difference across strategies. For example, to compare the transferability across landscapes of species vs. structural-based indicators with high data resolution, we calculated $t$-values for the differences $\left\{\left[\left(a_{12^{-}} a_{11}\right),\left(c_{12^{-}} c_{11}\right)\right]+\left[\left(a_{13^{-}} a_{11}\right),\left(c_{13^{-}} c_{11}\right)\right]+\ldots+\left[\left(a_{31^{-}} a_{33}\right),\left(c_{31^{-}} c_{33}\right)\right]+\right.$ $\left.\left[\left(a_{32}-a_{33}\right),\left(c_{32}-c_{33}\right)\right]\right\}$ (Fig. 1$)$. And to compare the transferability from landscape to regional scale, we performed a $t$-test on the difference $\left\{\left[\left(a_{41^{-}} a_{44}\right),\left(c_{41^{-}} c_{44}\right)\right]+\left[\left(a_{42^{-}}\right.\right.\right.$ 
$\left.\left.\left.a_{44}\right),\left(c_{42}-c_{44}\right)\right]+\left[\left(a_{43^{-}}-a_{44}\right),\left(c_{43^{-}}-c_{44}\right)\right]\right\}$ (Fig. 1). These tests are designed such that a positive or negative $t$-value indicates that the use of exogenous indicators yields a gain or loss in explanatory power respectively, and that a large difference between two indicator combinations indicates that one has a high transferability and the other a low transferability.

\section{3 - Results}

We captured a total of 7295 individuals of 140 bird species in the fragmented and control landscapes. The 50\% FC landscape had the highest species richness and diversity (Species observed $=87$, Shannon Index $=3.59$ ), while a lower diversity was found in the $30 \%$ landscape (Species observed $=62$, Shannon Index $=3.32$ ) and $10 \%$ FC landscape (Species observed $=69$, Shannon Index $=3.16$ ). Of the 140 species, 23 were only captured in the control landscapes, and therefore were omitted from all analyses of indicator selection.

\section{Selecting indicators at the regional and landscape scale}

Using high resolution data at the regional scale, six species had UI scores above the cutoff value of 1.82 and were thus selected as indicators (Table S2). Three species were positively related to community integrity (sensitive species) while the remaining were negatively related to this gradient (tramp species). The set of indicator species was well correlated with changes in community integrity $\left(R^{2}=0.76, \mathrm{~F}_{6,46}=24.08, P\right.$-value $<$ 0.0001, Fig. 3a). The set of structural indicators contained a similar number of variables (five PCA axes) and also resulted in a significant relationship, but slightly weaker $\left(\mathrm{R}^{2}=\right.$ $0.62, F_{5,47}=15.16, P$-value $<0.0001$, Fig. $\left.3 c\right)$. 
There was a different pattern using high resolution data at the landscape scale. In all three landscapes (10, 30 and 50\% FC), the sensitivity of structural indicators outperformed that of species-based indicators (Fig. 3a,c). Structural indicators explained an average of $96 \%(\mathrm{SD}=0.03)$ of the variation in ecological integrity, whereas sets of indicator species explained an average of $78 \%(S D=0.07)$ across the three landscapes. Although the number of comparisons was too low to yield a statistically significant difference, the effect size was 5.28 indicating that the mean of one group is past the 97.7 percentile standing of the other group (Cohen, 1988). This indicates that the relative sensitivity of species-based and structural-based indicators can be considered significantly different. However, it should be noted that structural indicators required, on average, a larger number of variables (from 10 to 11 PCA axes) than required by indicator species (four to five species) (Table S2, Fig. 3a,c).

\section{Changing data resolution}

Reducing data resolution had variable and scale-dependent impacts on the species-based indicators, and a consistent negative impact on structural-based indicators (Fig. 3b,d). At the regional scale, the use of data on species presence-absence yielded results that were stronger $\left(R^{2}=0.88, \mathrm{~F}_{7,45}=45.06, P\right.$-value $\left.<0.0001\right)$ than the ones originated from abundance data (Fig. 3a,b), while at the landscape scale the reduction in data resolution yielded weaker results $($ Effect Size $=1.98$, Percentile $=97.1)$. For structural indicators, the reduction in data resolution from a $10-\mathrm{m}$ to a $30-\mathrm{m}$ pixel image led to a reduction in explanatory power both at the regional scale $\left(R^{2}=0.57, \mathrm{~F}_{4,48}=16.40, P\right.$-value $<0.0001$, Fig. 3c,d) and at the landscape scale (Effect Size $=12.29$, Percentile $>97.7$ ). 
Testing indicator transferability across landscapes and scales

The sensitivity of high resolution indicator species to changes in community integrity decreased by an average of $28.5 \%$ when using exogenous indicators (Fig. 3a). By contrast, high resolution structural indicators had much higher transferability across landscapes and resulted in an average loss of explanatory power of just 5.5\% (Effect Size $=3.57$, Percentile $<$ 97.7, Fig. 3c). There was little difference in the transferability of species-based and structural-based indicators built with low resolution data (mean loss in explanatory power was 14 and 16\% respectively, Fig. 3). The transferability of indicator species was similar at high and low resolution $($ Effect Size $=0.82$, Percentile $=$ 79), but considerably lower for structural-based indicators at low resolution data (Effect Size $=4.33$, Percentile $<97.7)$.

Indicator species selected using landscape scale datasets performed poorly when tested on regional data (mean loss in explanatory power $=25 \%$ ), a trend that was not observed for structural indicators which showed an average loss in explanatory power of just 3.5\% (Effect Size $=5.90$, Percentile $<97.7$, Fig. 3). On the other hand, both species and structural indicators selected using regional data with high data resolution lost a similar, and considerable, amount of explanatory power when applied to the landscape scale (mean loss in explanatory power $=23$ and 22\% respectively, Effect Size $=0.11$, Percentile < 54), suggesting that the patterns observed at a large scale may not have direct relevance at a more local scale. The transferability of indicator species was not only poor for high resolution data; it was also poor and variable for low resolution data across scales (an average loss of 27\%, although in one case exogenous indicators had better prediction than endogenous ones), while structural indicators built from low resolution data had a consistently high transferability both from the regional to 
landscape scale and vice-versa (Mean loss in explanatory power $=8$ and 6\% respectively).

\section{4 - Discussion}

It would be expected that bird species would generate the best indicators for the bird community, but we found that structural indicators based on remotely sensed landscape metrics outperformed the use of species-based indicators. Using subsets of 13 original landscape metrics, we were able to explain an average of $96 \%$ of the variation in bird community integrity at the landscape scale, compared to just $78 \%$ using indicator species. Moreover, the results from structural indicators were less variable and more transferable across landscapes and scales than those obtained from indicator species (Fig. 3).

Despite the clear superiority of structural indicators, it would be incorrect to conclude that the use of indicator species would be an inefficient strategy in the Atlantic Forest. In fact, the models relating indicator species to changes in species community were among the strongest in the published literature (Faith, 2003; Mac Nally \& Fleishman, 2004), with $R^{2}$ values ranging from 0.44 to 0.88 . Had we not directly compared the use of indicator species to the use of structural indicators, we would almost certainly have concluded that indicator species are an efficient strategy that should be pursued. However, we found that indicator species yielded variable outcomes, which was partly caused by the variable efficiency of the UI method (e.g. 30\% FC landscape with low resolution data, Fig. 3b, Table S2), and also, this strategy had low transferability; two characteristics which are strongly undesirable when using indicators to design a conservation strategy (Hess et al., 2006). 
The transferability of indicator species selected using either high or low data resolution were consistently low, resulting in an average $25 \%$ loss in the ability of those indicators to reflect changes to community integrity. These results corroborate previous findings that changes in the observational scale and study region strongly affect the efficiency of the use of indicator species (Weaver, 1995; Hess et al., 2006; Billeter et al., 2008). This outcome, however, has a strong biological basis and is probably due to the three fragmented landscapes having a different degree of habitat loss. For instance, some species selected as good indicators for one landscape were not even captured in other landscapes, either because they were too forest-dependent and thus only occurred in the 50\% FC landscape (e.g. Myrmotherula gularis), or because they were too disturbance-dependent and only occurred in the 10\% FC landscape (e.g. Arremon taciturnus). It is to be expected that indicators selected from replicate landscapes with a similar amount of forest cover would show much higher transferability, as has been shown in other biomes (Mac Nally \& Fleishman, 2004; Betrus et al., 2005). Nonetheless, in a heavily fragmented biome such as the Atlantic Forest, it is important to be able to identify a single set of indicator species that can be used across the full gradient of habitat loss and fragmentation that exists. If this is not possible, alternative indicators must be considered.

Structural indicators proved to be a powerful and reliable alternative to the use of indicator species. Although structural indicators performed slightly worse than indicator species as endogenous indicators at the regional scale, this result was more than compensated by the consistently high explanatory power of structural indicators at the landscape scale (Fig. 3). Structural indicators had reduced sensitivity to changes in community integrity when low resolution data was used to generate them, but even the low resolution structural indicators were comparable in sensitivity to the high resolution 
indicator species. Perhaps most importantly, the transferability of structural indicators was very high in almost all cases, with the one exception being the transferability from regional indicators to the landscape scale. However, even in this case, the regional indicator was able to explain more than $70 \%$ of the changes in community integrity.

The use of structural indicators has further advantages over the use of indicator species that should not be overlooked. First, landscape metrics can be obtained for any place for which satellite images are available, such as from the free Landsat archive (www.landcover.org), while the use of indicator species requires field work which is often expensive and time consuming (Gardner et al., 2008). Second, landscape metrics always yield one measure per site, while indicator species might go undetected at the time of sampling creating the problem of "absence of information" (Metzger et al., 2008). Third, there is a substantial number of studies from many parts of the world showing how habitat loss and fragmentation affect species and communities, and this knowledge can help direct the selection of structural variables to be used as indicators (Ribeiro et al., 2009). As shown in our analysis of birds in the Atlantic Forest, there is high transferability of structural indicators across landscapes and from the landscape to the regional level. Thus, local studies that have identified landscape metrics that are correlated with changes in community composition can be used as indicators for nearby regions or for use at a larger spatial scale.

Structural indicators have many advantages over species indicators, but it is important to stress that we would have not reached this result had we not performed an exhaustive biological survey to measure the effects of forest fragmentation and habitat loss on bird community integrity. Consequently, it will always be necessary to conduct field surveys to collect information on the strength of species responses to changes in their habitat as to identify, select and validate structural indicators. Furthermore, it is 
possible that this result was produced because birds show very strong responses to habitat loss, fragmentation and degradation (Ferraz et al., 2007; Barlow et al., 2007; Gardner et al., 2008; Martensen et al., 2008), and that if we were studying other taxa that respond to alternative features of the environment that we did not measure (Dixo \& Martins, 2008), then species indicators may outperform structural indicators. However, there is now considerable evidence showing that the major causes of the widespread loss of biodiversity are habitat loss (Fahrig, 2003) and fragmentation (Ewers \& Didham, 2006), and that forest-dependent species are similarly affected by these variables (Pardini et al., 2009; Metzger et al., 2009). Such a consistently observed causal relationship should be regarded as a stronger basis for designing indicators than a simple correlation between species occurrence and high species richness. Therefore, we suggest that structural indicators may be a more parsimonious approach than species indicators in situations where there is strong, prior knowledge about the environmental variables that affect species and communities, whereas species indicators may be more parsimonious in situations where there is poor knowledge of the taxon biology.

Our results are among the strongest patterns recorded of the impacts of landscape modification on community composition, and lead us to advocate the use of landscape structural indicators for both monitoring and assessing the conservation value of Atlantic Forest areas. It is much easier for governments, NGOs and conservation stakeholders to identify landscapes of high conservation value using satellite imagery than it is to embark on a search for a 'best' indicator taxon that will often show poor spatial congruence with the species richness of other taxa. In a time when areas for conservation have to be selected hastily, the use of landscape structural indicators seems to be the best, easiest and cheapest strategy for identifying areas with high community integrity. 


\section{Acknowledgements}

We would like to thank all field assistants, in particular J.R. Mello Jr. and C.H. Parruco.

We also thank J. Barlow and T. Gardner for helpful comments on this manuscript. Research support was provided by CNPq, CAPES, Instituto de Biociências/USP, Imperial College London, SELVA and BIOCAPSP.

\section{References}

Andelman, S. J. \& Fagan, W. F. (2000) Umbrellas and flagships: Efficient conservation surrogates or expensive mistakes? Proceedings of the National Academy of Sciences of the United States of America, 97, 5954-5959.

Andrén, H. (1994) Effects of habitat fragmentation on birds and mammals in landscapes with different proportions of suitable habitat: a review. Oikos, 71, 355-366.

Araujo, M. B., Humphries, C. J., Densham, P. J., Lampinen, R., Hagemeijer, W. J. M., Mitchell-Jones, A. J., \& Gasc, J. P. (2001) Would environmental diversity be a good surrogate for species diversity? Ecography, 24, 103-110.

Awade, M. \& Metzger, J. P. (2008) Using gap-crossing capacity to evaluate functional connectivity of two Atlantic rainforest birds and their response to fragmentation. Austral Ecology, 33, 863-871.

Barlow, J., Gardner, T. A., Araujo, I. S., Avila-Pires, T. C., Bonaldo, A. B., Costa, J. E., Esposito, M. C., Ferreira, L. V., Hawes, J., Hernandez, M. I. M., Hoogmoed, M. S., Leite, R. N., Lo-Man-Hung, N. F., Malcolm, J. R., Martins, M. B., Mestre, L. A. M., Miranda-Santos, R., Nunes-Gutjahr, A. L., Overal, W. L., Parry, L., Peters, S. L., Ribeiro-Junior, M. A., da Silva, M. N. F., Silva Motta, C., \& Peres, C. A. (2007) Quantifying the biodiversity value of tropical primary, secondary, and plantation forests. Proceedings of the National Academy of Sciences, 104, 18555-18560.

Basset, Y., Missa, O., Alonso, A., Miller, S. E., Curletti, G., De Meyer, M., Eardley, C., Lewis, O. T., Mansell, M. W., Novotny, V., \& Wagner, T. (2008) Changes in arthropod assemblages along a wide gradient of disturbance in Gabon. Conservation Biology, 22, 1552-1563.

Betrus, C. J., Fleishman, E., \& Blair, R. B. (2005) Cross-taxonomic potential and spatial transferability of an umbrella species index. Journal of Environmental Management, 74, 79-87.

Billeter, R., Liira, J., Bailey, D., Bugter, R., Arens, P., Augenstein, I., Aviron, S., Baudry, J., Bukacek, R., Burel, F., Cerny, M., De Blust, G., De Cock, R., Diekotter, 
T., Dietz, H., Dirksen, J., Dormann, C., Durka, W., Frenzel, M., Hamersky, R., Hendrickx, F., Herzog, F., Klotz, S., Koolstra, B., Lausch, A., Le Coeur, D., Maelfait, J. P., Opdam, P., Roubalova, M., Schermann, A., Schermann, N., Schmidt, T., Schweiger, O., Smulders, M. J. M., Speelmans, M., Simova, P., Verboom, J., van Wingerden, W. K. R. E., \& Zobel, M. (2008) Indicators for biodiversity in agricultural landscapes: a pan-European study. Journal of Applied Ecology, 45, 141150.

Boscolo, D. (2007) Influência da estrutura da paisagem sobre a persistência de três espécies de aves em paisagens fragmentadas da Mata Atlântica. PhD Thesis. Universidade de São Paulo, São Paulo.

Bried, J. T., Herman, B. D., \& Ervin, G. N. (2007) Umbrella potential of plants and dragonflies for wetland conservation: a quantitative case study using the umbrella index. Journal of Applied Ecology, 44, 833-842.

Bubb, P., Jenkins, M., \& Kapos, V. (2006) Biodiversity indicators for national use: Experience and guidance. p. -16. UNEP-WCMC, Cambridge, UK. http://www.unepwcmc.org/resources/publications/binu/

Burnham K.P \& Anderson, D. (1998) Model Selection and Inference (AIC). Model Selection and Inference pp. 1-31.

Cabeza, M., Arponen, A., \& Van Teeffelen, A. (2008) Top predators: hot or not? A call for systematic assessment of biodiversity surrogates. Journal of Applied Ecology, 45, 976-980.

Caro, T. M. (2003) Umbrella species: critique and lessons from East Africa. Animal Conservation, 6, 171-181.

Cohen, J. (1988) Statistical power analysis for the behavioral sciences, 2nd edn. Lawrence Earlbaum Associates, Hillsdale.

Dixo, M. \& Martins, M. (2008) Are leaf-litter frogs and lizards affected by edge effects due to forest fragmentation in Brazilian Atlantic forest? Journal of Tropical Ecology, 24, 551-554.

Ewers, R. M. \& Didham, R. K. (2006) Confounding factors in the detection of species responses to habitat fragmentation. Biological Reviews, 81, 117-142.

Fahrig, L. (2003) Effects of habitat fragmentation on biodiversity. Annual Review of Ecology, Evolution and Systematics, 34, 487-515.

Faith, D. P. (2003) Environmental diversity (ED) as surrogate information for specieslevel biodiversity. Ecography, 26, 374-379.

Ferraz, G., Nichols, J. D., Hines, J. E., Stouffer, P. C., Bierregaard, R. O., Jr., \& Lovejoy, T. E. (2007) A large-scale deforestation experiment: effects of patch area and isolation on Amazon birds. Science, 315, 238-241.

Fleishman, E., Murphy, D. D., \& Brussard, P. E. (2000) A new method for selection of umbrella species for conservation planning. Ecological Applications, 10, 569-579. 
Fleishman, E., Nally, R. M., \& Fay, J. P. (2003) Validation tests of predictive models of butterfly occurrence based on environmental variables. Conservation Biology, 17, 806-817.

Fleishman, E., Ray, C., Sjogren-Gulve, P., Boggs, C. L., \& Murphy, D. D. (2002) Assessing the roles of patch quality, area, and isolation in predicting metapopulation dynamics. Conservation Biology, 16, 706-716.

Fletcher, R. J. (2005) Multiple edge effects and their implications in fragmented landscapes. Journal of Animal Ecology, 74, 342-352.

Franco, A. M. A., Anderson, B. J., Roy, D. B., Gillings, S., Fox, R., Moilanen, A., \& Thomas, C. D. (2009) Surrogacy and persistence in reserve selection: landscape prioritization for multiple taxa in Britain. Journal of Applied Ecology, 46, 82-91.

Gardner, T. A., Barlow, J., Araujo, I. S., Avila-Pires, T. C., Bonaldo, A. B., Costa, J. E., Esposito, M. C., Ferreira, L. V., Hawes, J., Hernandez, M. I. M., Hoogmoed, M. S., Leite, R. N., Lo-Man-Hung, N. F., Malcolm, J. R., Martins, M. B., Mestre, L. A. M., Miranda-Santos, R., Overal, W. L., Parry, L., Peters, S. L., Ribeiro-Junior, M. A., da Silva, M. N. F., Silva Motta, C., \& Peres, C. A. (2008) The cost-effectiveness of biodiversity surveys in tropical forests. Ecology Letters, 11, 139-150.

Gotelli, N. J. \& Colwell, R. K. (2001) Quantifying biodiversity: procedures and pitfalls in the measurement and comparison of species richness. Ecology Letters, 4, 379-391.

Grenyer, R., Orme, C. D., Jackson, S. F., Thomas, G. H., Davies, R. G., Davies, T. J., Jones, K. E., Olson, V. A., Ridgely, R. S., Rasmussen, P. C., Ding, T. S., Bennett, P. M., Blackburn, T. M., Gaston, K. J., Gittleman, J. L., \& Owens, I. P. F. (2006) Global distribution and conservation of rare and threatened vertebrates. Nature, 444, 93-96.

Hess, G. R., Bartel, R. A., Leidner, A. K., Rosenfeld, K. M., Rubino, M. J., Snider, S. B., \& Ricketts, T. H. (2006) Effectiveness of biodiversity indicators varies with extent, grain, and region. Biological Conservation, 132, 448-457.

Hockey, P. A. R. \& Curtis, O. E. (2009) Use of basic biological information for rapid prediction of the response of species to habitat loss. Conservation Biology, 23, 64-71.

Kati, V., Dimopoulos, P., Papaioannou, H., \& Poirazidis, K. (2009) Ecological management of a Mediterranean mountainous reserve (Pindos National Park, Greece) using the bird community as an indicator. Journal for Nature Conservation, 17, 4759.

Laurance, S. G. (2004) Responses of understory rain forest birds to road edges in central Amazonia. Ecological Applications, 14, 1344-1357.

Lawton, J. H., Bignell, D. E., Bolton, B., Bloemers, G. F., Eggleton, P., Hammond, P. M., Hodda, M., Holt, R. D., Larsen, T. B., Mawdsley, N. A., Stork, N. E., Srivastava, D. S., \& Watt, A. D. (1998) Biodiversity inventories, indicator taxa and effects of habitat modification in tropical forest. Nature, 391, 72-76. 
Legendre, P. \& Legendre, L. (1998) Numerical Ecology: Second English Edition. Elsevier Science B.V., Amsterdam.

Lindenmayer, D. B., Cunningham, R. B., Donnelly, C. F., \& Lesslie, R. (2002a) On the use of landscape surrogates as ecological indicators in fragmented forests. Forest Ecology and Management, 159, 203-216.

Lindenmayer, D. B., Cunningham, R. B., Donnelly, C. F., Nix, H., \& Lindenmayer, B. D. (2002b) Effects of forest fragmentation on bird assemblages in a novel landscape context. Ecological Monographs, 72, 1-18.

Mac Nally, R. \& Fleishman, E. (2004) A successful predictive model of species richness based on indicator species. Conservation Biology, 18, 646-654.

Mace, G. M. \& Baillie, J. E. M. (2007) The 2010 biodiversity indicators: Challenges for science and policy. Conservation Biology, 21, 1406-1413.

Manne, L. L. \& Williams, P. H. (2003) Building indicator groups based on species characteristics can improve conservation planning. Animal Conservation, 6, 291-297.

Martensen, A. C., Pimentel, R. G., \& Metzger, J. P. (2008) Relative effects of fragment size and connectivity on bird community in the Atlantic Rain Forest: Implications for conservation. Biological Conservation, 141, 2184-2192.

Mattfeldt, S. D., Bailey, L. L., \& Grant, E. H. C. (2009) Monitoring multiple species: Estimating state variables and exploring the efficacy of a monitoring program. Biological Conservation, 142, 720-737.

Mawdsley, J. \& O'Malley, R. (2009) Development of multi-species indicators for the Nevada Wildlife Action Plan. Ecological Indicators, 9, 1030-1036.

McGarigal, K. \& Marks, B. J. (1995) FRAGSTATS: Spatial pattern analysis program for quantifying landscape structure. General Technical Report PNW-GTR-351.

Metzger, J. P., Ribeiro, M. C., Ciocheti, G., \& Tambosi, L. R. (2008) Uso de índices de paisagem para a definição de ações de conservação e restauração da biodiversidade do Estado de São Paulo. Diretrizes para conservação e restauração da biodiversidade no Estado de São Paulo. ed. by R. R. Rodrigues, C. A. Joly, M. C. W. Brito, A. Paese, J. P. Metzger, L. Casatti, M. A. Nalon, N. Menezes, N. M. Ivanaukas, V. Bolzani, and V. L. R. Bononi, pp. 120-127. Secretaria do Meio Ambiente e Fapesp, São Paulo.

Metzger, J. P., Martensen, A. C., Dixo, M., Bernacci, L. C., Ribeiro, M. C., Teixeira, A. M. G., \& Pardini, R. (2009) Time-lag in biological responses to landscape changes in a highly dynamic Atlantic forest region. Biological Conservation, 142, 1166-1177.

Michel, A. K. \& Winter, S. (2009) Tree microhabitat structures as indicators of biodiversity in Douglas-fir forests of different stand ages and management histories in the Pacific Northwest, U.S.A. Forest Ecology and Management, 257, 1453-1464.

Noss, R. F. (1999) Assessing and monitoring forest biodiversity: A suggested framework and indicators. Forest Ecology and Management, 115, 135-146. 
Pardini, R., Faria, D., Accacio, G. M., Laps, R. R., Mariano-Neto, E., Paciencia, M. L. B., Dixo, M., \& Baumgarten, J. (2009) The challenge of maintaining Atlantic forest biodiversity: A multi-taxa conservation assessment of specialist and generalist species in an agro-forestry mosaic in southern Bahia. Biological Conservation, 142, 1178-1190.

Peters, M. K., Likare, S., \& Kraemer, M. (2008) Effects of habitat fragmentation and degradation on flocks of African ant-following birds. Ecological Applications, 18, 847-858.

R Development Core Team (2008) R: A language and environment for statistical computing. R: A language and environment for statistical computing, Vienna, Austria.

Ranganathan, J., Daniels, R. J. R., Chandran, M. D. S., Ehrlich, P. R., \& Daily, G. C. (2008) Sustaining biodiversity in ancient tropical countryside. Proceedings of the National Academy of Sciences, 105, 17852-17854.

Ribeiro, M. C., Metzger, J. P., Martensen, A. C., Ponzoni, F. J., \& Hirota, M. M. (2009) The Brazilian Atlantic Forest: How much is left, and how is the remaining forest distributed? Implications for conservation. Biological Conservation, 142, 1141-1153.

Rosenthal, R. \& Rosnow, R. L. (1991) Essentials of behavioral research: Methods and data analysis, 2nd edn. McGraw Hill, New York.

Roth, T. \& Weber, D. (2008) Top predators as indicators for species richness? Prey species are just as useful. Journal of Applied Ecology, 45, 987-991.

Su, J. C., Debinski, D. M., Jakubauskas, M. E., \& Kindscher, K. (2004) Beyond species richness: Community similarity as a measure of cross-taxon congruence for coarsefilter conservation. Conservation Biology, 18, 167-173.

Thomson, J. R., Fleishman, E., Nally, R. M., \& Dobkin, D. S. (2005) Influence of the temporal resolution of data on the success of indicator species models of species richness across multiple taxonomic groups. Biological Conservation, 124, 503-518.

Turner, W., Spector, S., Gardiner, N., Fladeland, M., Sterling, E., \& Steininger, M. (2003) Remote sensing for biodiversity science and conservation. Trends in Ecology \& Evolution, 18, 306-314.

Villard, M. A., Trzcinski, M. K., \& Merriam, G. (1999) Fragmentation effects on forest birds: relative influence of woodland cover and configuration on landscape occupancy. Conservation Biology, 13, 774-783.

Weaver, J. C. (1995) Indicator species and scale of observation. Conservation Biology, 9, 939-942. 


\section{Figure Legends}

Figure 1 - Schematic representation of the analysis. We compared the efficiency of two indicator strategies, species-based and landscape structural-based indicators, to represent changes in community integrity (bottom left) at the landscape and regional scales. We also assessed how changes in data resolution (abundance vs. species occurrence for species-based indicators, and $10 \mathrm{~m}$ vs. $30 \mathrm{~m}$ pixel size for structural indicators) affected the results, and assessed the potential transferability of each indicator strategy $\times$ data resolution combination. Paths 1 to 16 represent the selection of indicator sets as explained in the Methods. Paths $a_{11}, a_{22}, a_{33}$ and $a_{44}$ (as well as $b_{11}, b_{22}$ and so on), depicted in thick arrows, represent the selection and testing of indicators using a single dataset (endogenous indicators used for monitoring purposes). All remaining paths depicted in continuous thin arrows (such as $a_{21}, a_{31}, a_{12}$ ) represent analyses at a single spatial scale where indicators selected from one dataset were validated against other datasets (exogenous indicators used for assessment purposes). Paths depicted in dotted lines represent cross-scale validations of selected indicators, where we tested the transferability of indicators from the landscape to the regional scale and vice versa. The letters "b”, “c” and "d" represent the analyses used for assessing the efficiency of indicators using indicator species with low resolution and structural indicators with high and low resolution, respectively. The subscript $j$ refers to the dataset used to select the indicators, and $i$ refers to the dataset used to assess the efficiency of the indicators selected using dataset $i$.

Figure 2 - Results of an ordination of bird community composition (PCoA axis 1) across control landscapes (> $90 \%$ forest cover) and large, medium and small patches in landscapes with 50, 30 and $10 \%$ forest cover. Control landscapes had bird community 
compositions with low ordination scores, and the communities in large patches of the 50\% FC landscape were similar. Community composition gradually changes from that of the control landscapes as the proportion of forest cover in the landscape is reduced and as fragment size decreases. Thick lines represent the median, boxes represent the interquartile range and whiskers represent minimum and maximum values.

Figure 3 - Sensitivity of species-based $(a, b)$ and structural-based $(c, d)$ indicators to changes in bird community integrity, when generated using high data resolution $(a, c)$ and low data resolution $(b, d)$. $R$-squared values represent the explanatory power with which a given indicator set is able to reflect changes in community integrity. Black bars show the efficiency of endogenous indicators (selected and tested on the same dataset), and white bars show the transferability of exogenous indicators (selected from one dataset and tested on another). Numbers on the top of the bars show the number of variables included in the indicator set. From left to right, in the barplot showing the results for indicator species built with high resolution data, bars represent the results from the analyses performed on paths $a_{11}, a_{21}, a_{31}, a_{11}, a_{41}, a_{12}, a_{22}, a_{32}, a_{42}$, and so on (Fig. 1). 
Figure 1

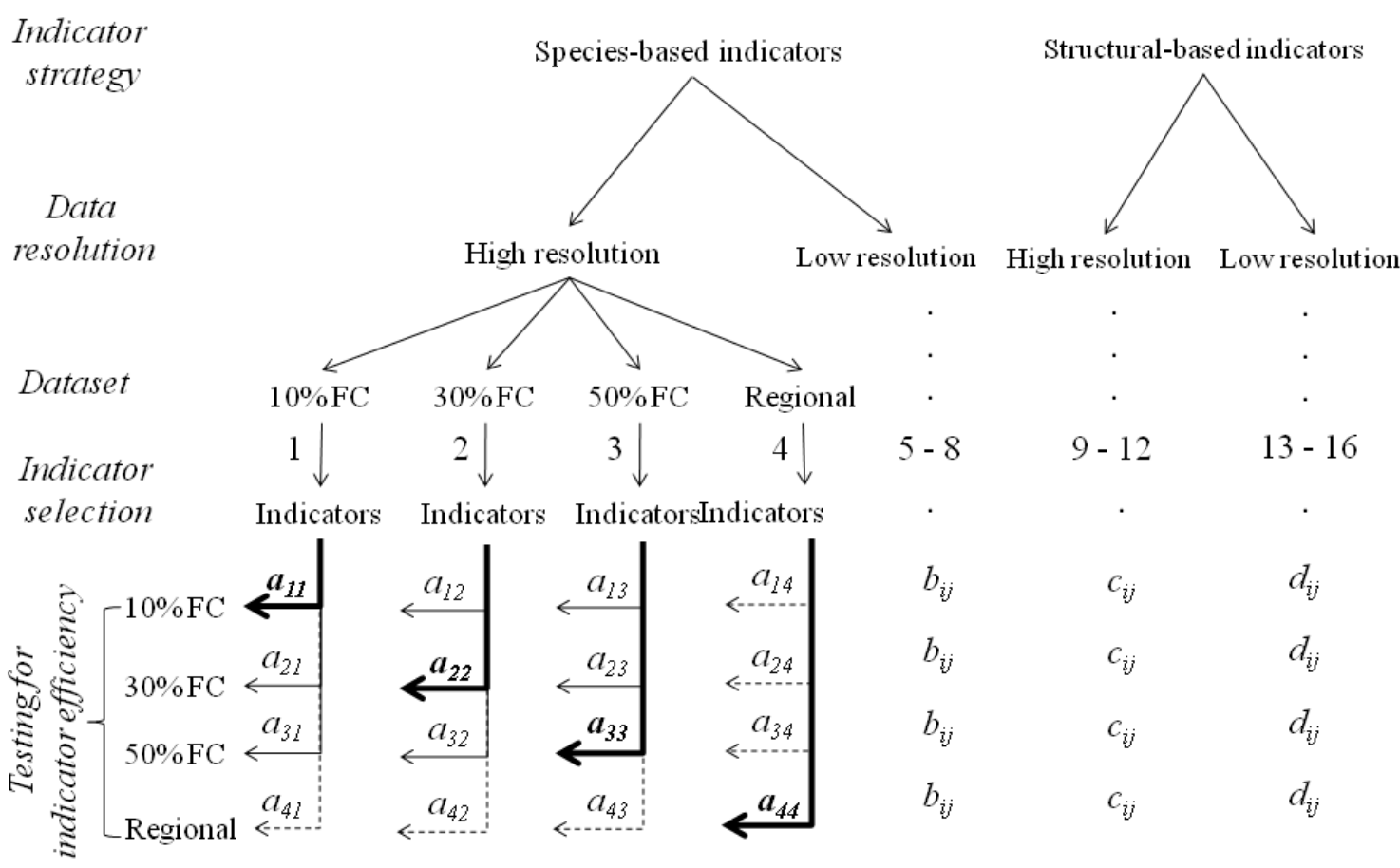


Figure 2

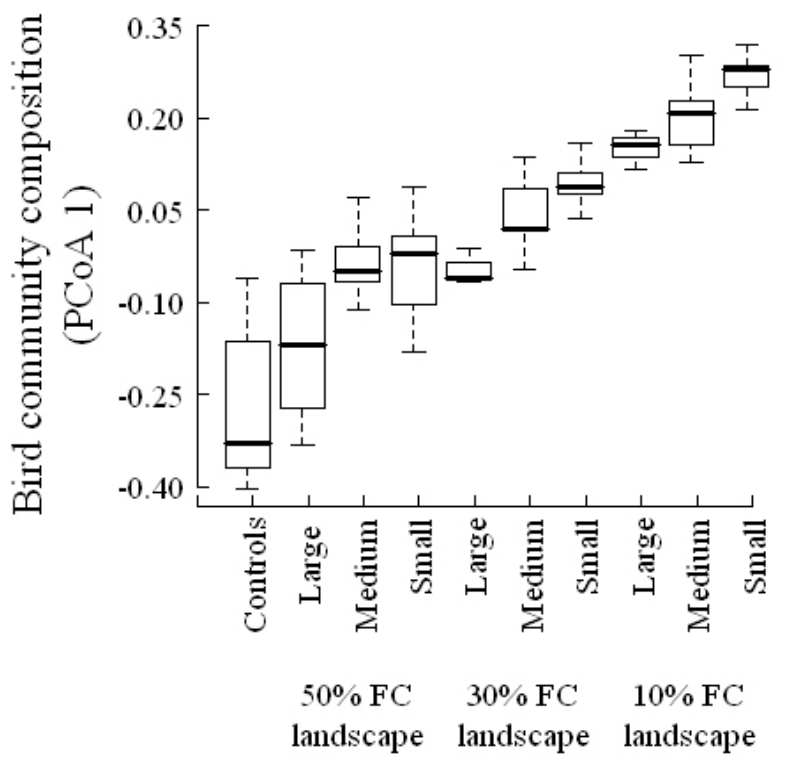


Figure 3

\section{Species-based indicators}

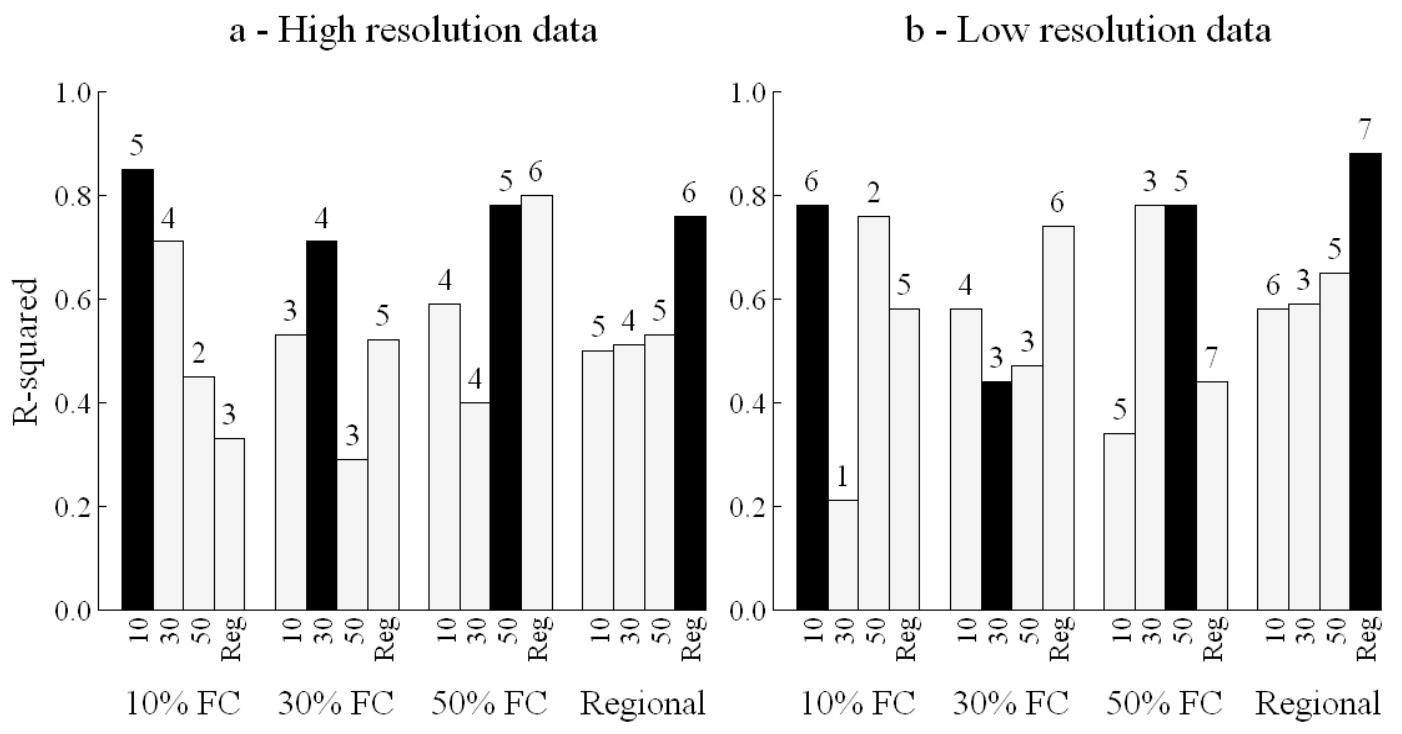

\section{Structural-based indicators}
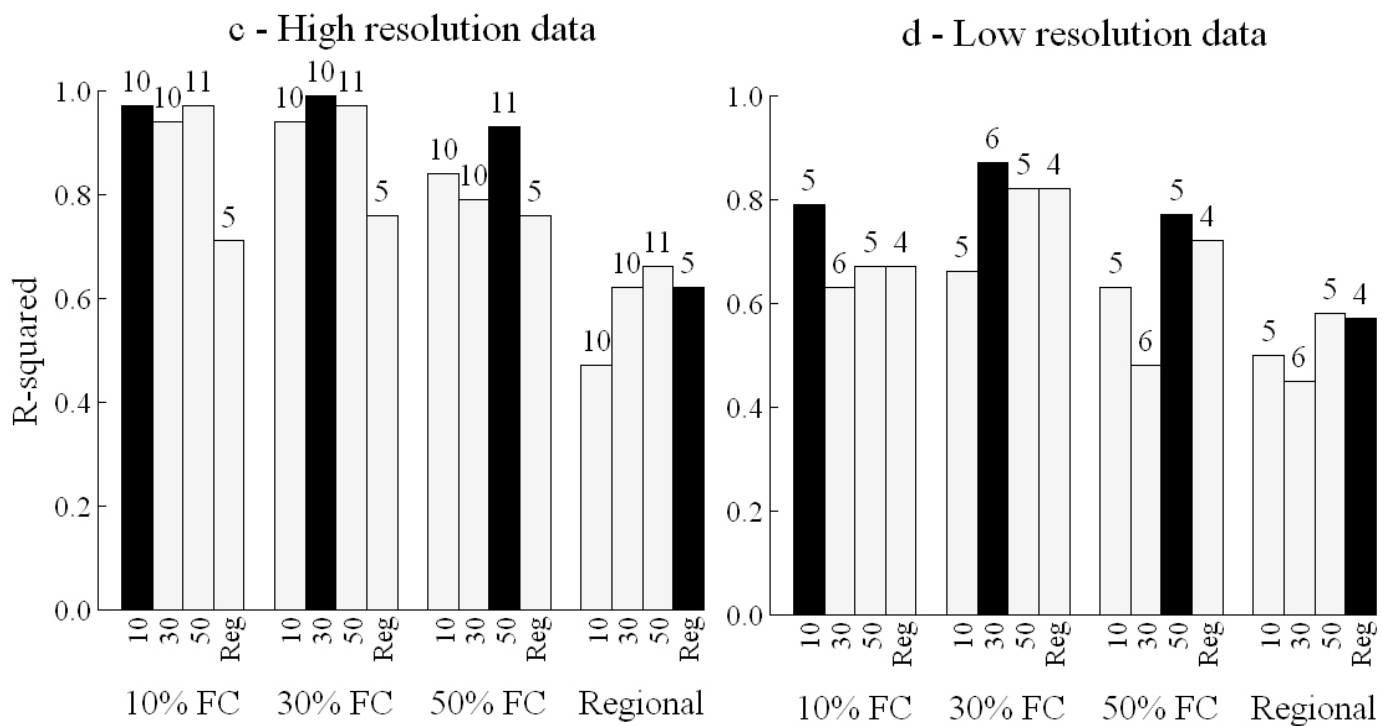


\section{5 - Supplementary Material}

\section{Differences in sampling protocol and effort across sites}

In the $10 \% \mathrm{FC}$ and $50 \% \mathrm{FC}$ landscapes and their paired continuous landscapes, birds were sampled for four surveys of two consecutive days. On the first day, nets were opened at sunrise and closed at sunset; on the second day nets were opened at sunrise and closed six hours later. In the 30\% FC landscape and paired continuous landscape, a slightly different protocol was used. Birds were sampled from sunrise until 9 hours later for eight, non-consecutive, days.

Landscapes varied slightly in sampling effort. Sites in continuous forests were sampled for an average of 624 net-hours (SD=94.2), while in the 10\% FC landscape the mean effort per sampling site was 699 net-hours $(\mathrm{SD}=21.7$ ), in the $30 \%$ FC landscape the mean effort per sampling site was 537 net-hours $(\mathrm{SD}=6.2)$ and in the $50 \% \mathrm{FC}$ landscape there was an equal sampling effort of 680 net-hours per site.

\section{Finding the best ordination procedure to measure changes in community integrity}

We built dissimilarity matrices using the Kulczynski, Gower, Jaccard, Bray-Curtis and Chi-square indices and then submitted these matrices to three ordinations procedures: principal coordinate analysis (PCoA), non-metric multidimensional scaling (NMDS) and hybrid multidimensional scaling (HMDS) (Faith et al., 1987). In all cases, the species by site matrix was standardised by range (values within 0 and 1) along columns (to reduce the influence of the most abundant species) and along rows (to control for differences in sampling effort across sites). We assessed the performance of ordinations 
with Shepard diagrams and by inspecting the scores as suggested by Oksanen (http://cc.oulu.fi/ jarioksa/softhelp/FAQ-vegan.html).

\section{References}

Faith, D. P., Minchin, P. R., \& Belbin, L. (1987) Compositional dissimilarity as a robust measure of ecological distance. Vegetatio, 69, 57-68.

McGarigal, K. \& Marks, B. J. (1995) FRAGSTATS: Spatial pattern analysis program for quantifying landscape structure. General Technical Report PNW-GTR-351. 
Table S1 - Correlation matrix of landscape metrics used for calculating structural-based indicators. Measured metrics were based on a Spot 5 image with $10 \mathrm{~m}$ resolution and calculated using Fragstats 3.3. See McGarigal \& Marks (1995) and text for a detailed explanation of how each metric is calculated. Significant correlations are indicated in bold.

\begin{tabular}{|c|c|c|c|c|c|c|c|c|c|c|c|c|}
\hline & $\begin{array}{l}\text { Patch } \\
\text { size }\end{array}$ & Perimeter & Shape & Contiguity & $\begin{array}{l}\text { Core } \\
\text { area } \\
20 \mathrm{~m}\end{array}$ & $\begin{array}{l}\text { Core } \\
\text { area } \\
50 \mathrm{~m}\end{array}$ & $\begin{array}{c}\text { Core } \\
\text { area } \\
100 \mathrm{~m}\end{array}$ & $\begin{array}{c}\text { Poximity } \\
20 \mathrm{~m}\end{array}$ & $\begin{array}{c}\text { Proximity } \\
50 \mathrm{~m}\end{array}$ & $\begin{array}{c}\text { Proximity } \\
100 \mathrm{~m}\end{array}$ & $\begin{array}{c}\begin{array}{l}\text { Forest } \\
\text { cover } \\
300 \mathrm{~m}\end{array} \\
\end{array}$ & $\begin{array}{c}\text { Forest } \\
\text { cover } \\
500 \mathrm{~m}\end{array}$ \\
\hline Perimeter & 0.972 & & & & & & & & & & & \\
\hline Shape & 0.808 & 0.924 & & & & & & & & & & \\
\hline Contiguity & 0.773 & 0.613 & 0.282 & & & & & & & & & \\
\hline $\begin{array}{l}\text { Core area } \\
20 \mathrm{~m}\end{array}$ & 0.997 & 0.957 & 0.775 & 0.801 & & & & & & & & \\
\hline $\begin{array}{l}\text { Core area } \\
50 \mathrm{~m}\end{array}$ & 0.985 & 0.926 & 0.720 & 0.827 & 0.993 & & & & & & & \\
\hline $\begin{array}{l}\text { Core area } \\
100 \mathrm{~m}\end{array}$ & 0.914 & 0.854 & 0.655 & 0.732 & 0.930 & 0.948 & & & & & & \\
\hline $\begin{array}{l}\text { Proximity } \\
20 \mathrm{~m}\end{array}$ & 0.555 & 0.553 & 0.484 & 0.394 & 0.557 & 0.553 & 0.530 & & & & & \\
\hline $\begin{array}{l}\text { Proximity } \\
50 \mathrm{~m}\end{array}$ & 0.379 & 0.400 & 0.386 & 0.183 & 0.384 & 0.387 & 0.438 & 0.584 & & & & \\
\hline $\begin{array}{l}\text { Proximity } \\
100 \mathrm{~m}\end{array}$ & 0.336 & 0.371 & 0.383 & 0.089 & 0.340 & 0.346 & 0.417 & 0.571 & 0.924 & & & \\
\hline $\begin{array}{l}\text { Forest cover } \\
300 \mathrm{~m}\end{array}$ & 0.850 & 0.790 & 0.598 & 0.709 & 0.863 & 0.877 & 0.879 & 0.451 & 0.481 & 0.458 & & \\
\hline $\begin{array}{l}\text { Forest cover } \\
500 \mathrm{~m}\end{array}$ & 0.708 & 0.685 & 0.567 & 0.483 & 0.724 & 0.738 & 0.803 & 0.485 & 0.690 & 0.707 & 0.867 & \\
\hline $\begin{array}{l}\text { Forest cover } \\
800 \mathrm{~m}\end{array}$ & 0.475 & 0.472 & 0.410 & 0.248 & 0.492 & 0.507 & 0.607 & 0.451 & 0.734 & 0.787 & 0.625 & 0.901 \\
\hline
\end{tabular}


Table S2 - Indicator species selected for the 10\% FC, 30\% FC and 50\% FC landscapes and at the regional level, with high and low data resolution. For each species, we present the sign of correlation with community composition (negative signs represent species that occur in more intact sites and positive signs indicate species that prefer disturbed places), number of captures in the fragments, the number of sites where the species was recorded (from a total of 53) and the measured Umbrella Index (UI).

High resolution data

Low resolution data

\begin{tabular}{|c|c|c|c|c|c|c|c|c|c|c|c|}
\hline \multirow{7}{*}{ 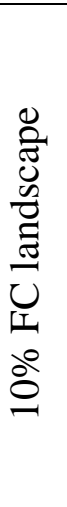 } & Species & Sign & $\mathrm{N}^{\circ}$ Capt & $\mathrm{N}^{\circ}$ sites & UI & \multirow{7}{*}{ 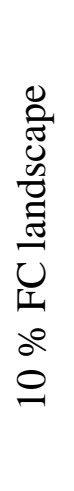 } & Species & Sign & $\mathrm{N}^{\circ}$ Capt & $\mathrm{N}^{\circ}$ sites & UI \\
\hline & Corythopis delalandi & - & 8 & 5 & 1.94 & & Arremon taciturnus & - & 7 & 5 & 1.79 \\
\hline & Habia rubica & - & 21 & 5 & 2.28 & & Haplospiza unicolor & + & 7 & 3 & 1.85 \\
\hline & Lepidocolaptes fuscus & - & 67 & 10 & 1.99 & & Lepidocolaptes fuscus & - & 67 & 10 & 1.86 \\
\hline & Leptopogon amaurocephalus & - & 22 & 9 & 1.93 & & Leptopogon amaurocephalus & - & 22 & 9 & 1.81 \\
\hline & Schiffornis virescens & - & 36 & 8 & 2.04 & & Lochmias nematura & + & 15 & 5 & 1.89 \\
\hline & & & & & & & Schiffornis virescens & - & 36 & 8 & 1.96 \\
\hline \multirow{5}{*}{ 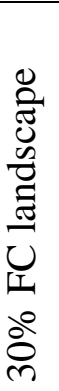 } & Species & Sign & $\mathrm{N}^{\circ}$ Capt & $\mathrm{N}^{\circ}$ sites & UI & \multirow{5}{*}{ 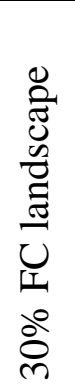 } & Species & Sign & $\mathrm{N}^{\circ}$ Capt & $\mathrm{N}^{\circ}$ sites & UI \\
\hline & Schiffornis virescens & - & 36 & 11 & 2.04 & & Automolus leucophthalmus & - & 18 & 7 & 2.18 \\
\hline & Sclerurus scansor & - & 35 & 10 & 2.37 & & Myrmeciza squamosa & - & 9 & 5 & 1.96 \\
\hline & Sittasomus griseicapillus & - & 22 & 11 & 1.98 & & Sclerurus scansor & - & 35 & 10 & 1.89 \\
\hline & Turdus albicollis & - & 90 & 14 & 2.02 & & & & & & \\
\hline
\end{tabular}


High resolution data

Low resolution data

\begin{tabular}{|c|c|c|c|c|c|c|c|c|c|c|c|}
\hline \multirow{6}{*}{ 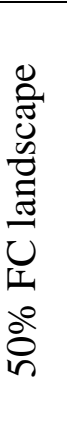 } & Species & Sign & $\mathrm{N}^{\circ}$ Capt & $\mathrm{N}^{\circ}$ sites & UI & \multirow{6}{*}{ 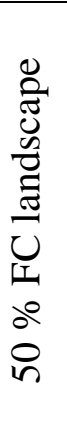 } & Species & Sign & $\mathrm{N}^{\circ}$ Capt & $\mathrm{N}^{\circ}$ sites & UI \\
\hline & Habia rubica & - & 19 & 4 & 2.19 & & Automolus leucophthalmus & - & 12 & 5 & 2.55 \\
\hline & Hylophilus poicilotis & + & 3 & 3 & 2.03 & & Habia rubica & - & 19 & 4 & 2.00 \\
\hline & Mionectes rufiventris & - & 26 & 12 & 1.98 & & Myiobius atricaudus & - & 5 & 5 & 1.90 \\
\hline & Myrmeciza squamosa & - & 14 & 8 & 2.00 & & Myrmeciza squamosa & - & 14 & 8 & 1.90 \\
\hline & Myrmotherula gularis & - & 14 & 7 & 2.32 & & Schiffornis virescens & - & 37 & 11 & 1.95 \\
\hline \multirow{8}{*}{ 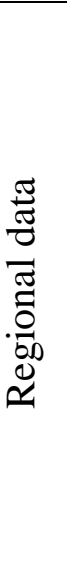 } & Species & Sign & $\mathrm{N}^{\circ}$ Capt & $\mathrm{N}^{\circ}$ sites & $\mathrm{UI}$ & \multirow{8}{*}{ 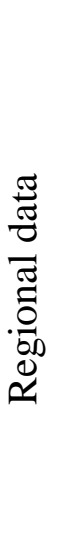 } & Species & Sign & $\mathrm{N}^{\circ}$ Capt & $\mathrm{N}^{\circ}$ sites & UI \\
\hline & Automolus leucophthalmus & + & 198 & 29 & 1.87 & & Lepidocolaptes fuscus & - & 273 & 46 & 1.83 \\
\hline & Myrmeciza squamosa & - & 23 & 13 & 1.88 & & Myrmeciza squamosa & - & 23 & 13 & 1.86 \\
\hline & Myrmotherula gularis & - & 14 & 7 & 2.24 & & Myrmotherula gularis & - & 14 & 7 & 1.88 \\
\hline & Sclerurus scansor & - & 80 & 27 & 1.91 & & Pyriglena leucoptera & - & 156 & 33 & 1.87 \\
\hline & Synallaxis ruficapilla & + & 120 & 32 & 1.88 & & Sclerurus scansor & - & 80 & 27 & 1.92 \\
\hline & \multirow[t]{2}{*}{ Thamnophilus caerulescens } & + & 84 & 30 & 1.91 & & Synallaxis ruficapilla & + & 120 & 32 & 1.86 \\
\hline & & & & & & & Thamnophilus caerulescens & + & 84 & 30 & 1.80 \\
\hline
\end{tabular}




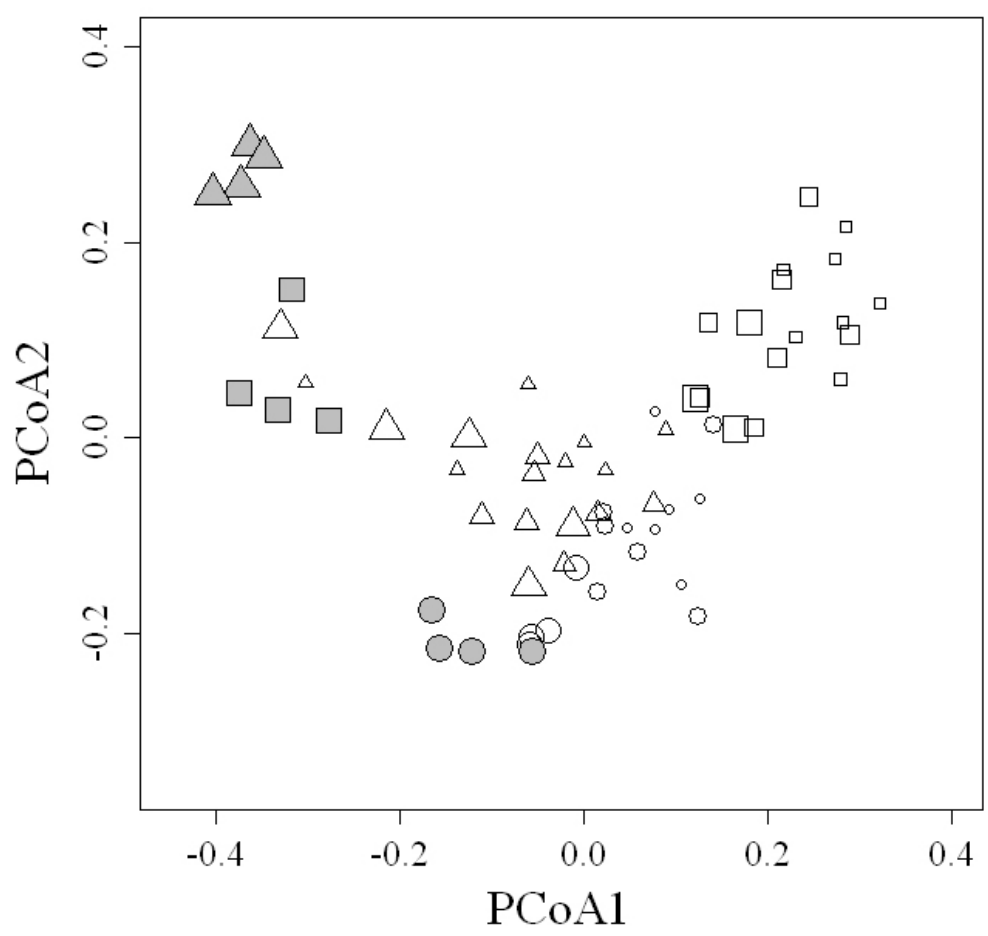

Figure S1 - Principal Coordinate Analysis plot, showing a distinctive horseshoe effect on the second axis. Open symbols represent the sites sampled in fragmented landscapes, triangles represent the sites at the 50\% FC landscape, circles represent the $30 \%$ FC landscape and squares represent the $10 \%$ FC landscape. Filled symbols represent the sites sampled at the control landscapes, with their shape matching that of the fragmented landscape with which they were paired. 


\section{Capítulo 7}

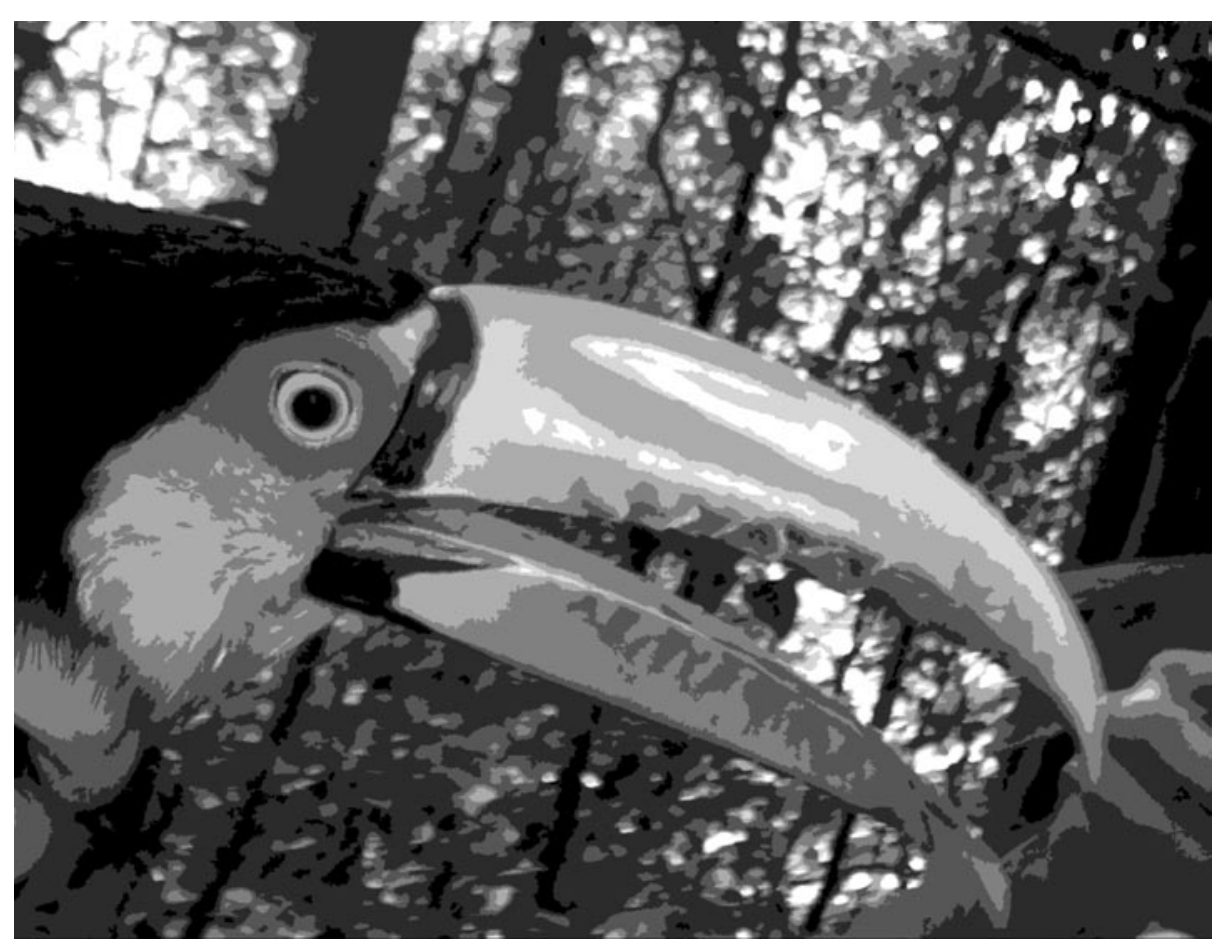




\section{1 - Discussão}

Esta tese proporcionou uma melhor compreensão sobre como a comunidade de aves de sub-bosque é influenciada pelos efeitos das mudanças antropogênicas em habitats de Floresta Atlântica. Ao mesmo tempo, discutiu-se a causa dos padrões encontrados, o grau de influência de fatores correlacionados, e procurou-se avaliar a consistência e poder de extrapolação dos padrões. Por fim, o conhecimento gerado foi usado para propor práticas conservacionistas mais adequadas para a região e demais florestas tropicais.

Em termos gerais, em todos os capítulos apresentados nesta tese mostrou-se que as aves de sub-bosque são fortemente afetadas pelas mudanças na perda, fragmentação e qualidade do habitat em áreas de Floresta Atlântica. Estes resultados não são originais, mas o fato da comunidade de aves ter sido afetada pela perda e fragmentação do habitat simultaneamente, nos leva a uma discussão vigente sobre a importância relativa destes dois efeitos. Um dos artigos clássicos e mais citados sobre os efeitos da fragmentação de habitats sobre as espécies discute que enquanto os efeitos de perda de habitat são sempre fortes e negativos, os efeitos da fragmentação são fracos e variáveis (Fahrig, 2003). Fahrig (2003) considera que uma grande parte dos efeitos da fragmentação se deve aos efeitos de perda de habitat, pois medidas como tamanho de fragmento são basicamente medidas de área (logo, de perda de habitat), mas aponta que existe a influência adicional de efeitos de borda, os quais seriam uma das principais causas desta variabilidade dos efeitos de fragmentação.

Quão importantes são os efeitos de borda?

Efeitos de borda são de fato variáveis, mas estão longe de serem pouco importantes (Capítulo 2). Bordas consistem na justaposição de dois ambientes distintos e podem ser 
encontradas em todos os ambientes terrestres e aquáticos deste planeta. Em condições onde estes habitats ocorrem naturalmente, diversas espécies se especializaram em utilizar bordas enquanto outras ativamente evitam estes habitats (Leopold, 1933; Laurance, 2008). Porém, em paisagens alteradas pela ação humana, o estudo de bordas se voltou para o de bordas antropogênicas, onde há a interação entre um ambiente natural e outro de uso humano. Assim como bordas naturais, bordas antropogênicas também são áreas que apresentam alteração nos fluxos de energia, materiais e organismos (Murcia, 1995), mas, por serem mais recentes, poucas espécies de fato se especializaram em utilizar estes habitats (Villard, 1998; Imbeau et al., 2003). Não obstante, é comum encontrar uma grande disparidade nos efeitos de borda sobre populações ou comunidades, que podem apresentar respostas negativas (e.g. menor abundância em bordas), positivas (e.g. maior abundância em bordas) ou neutras.

Diversas teorias foram propostas para explicar a causa da variabilidade nos efeitos de bordas (Baldi, 1996; Cadenasso \& Pickett, 2001; Ries \& Sisk, 2004; Ries et al., 2004; Ewers \& Didham, 2006; Lindell et al., 2007; Prugh et al., 2008). Alguns autores apontam diferenças biogeográficas, em que aves de ambientes tropicais são principalmente afetadas negativamente, enquanto aves de zonas temperadas tendem a responder positivamente (Lindell et al., 2007), uma vez que áreas temperadas possuem maior ocorrência de áreas abertas naturais e que as espécies mais sensíveis já foram extintas dado ao longo histórico de ocupação humana (Baldi, 1996). Outros autores discutem que parte da variabilidade dos efeitos de borda está relacionada à estrutura e composição das bordas, como a magnitude da diferença na estrutura da vegetação entre os habitats justapostos (Ries et al., 2004). Desta forma, efeitos de borda entre uma floresta e uma pastagem serão muito maiores do que os existentes em uma borda constituída por uma pradaria natural e uma pastagem (Capítulo 2, Fig. 4). Já outras 
teorias lidam com a questão metodológica de que há uma dificuldade intrínseca em estudar efeitos de borda em paisagens fragmentadas, pois há uma forte correlação entre a área de um fragmento e a extensão de sua borda (Laurance \& Yensen, 1991; Malcolm, 1994; Ewers et al., 2007).

Efeitos de borda também são importantes em fragmentos de floresta secundária?

Dado o contexto acima, seria esperado que os efeitos de borda sobre a comunidade de aves em uma área de Mata Atlântica secundária fossem mais fracos do que aqueles encontrados em áreas de vegetação primária contínua da Amazônia (Restrepo \& Gomez, 1998; Restrepo et al., 1999; Laurance, 2004; Laurance et al., 2004a). Os fragmentos estudados nesta tese são principalmente compostos por regeneração secundária após corte raso (Teixeira et al., 2009), o que significa não só que as espécies lá presentes são aquelas que colonizaram os fragmentos após sua extinção local, mas também que as diferenças em vegetação entre as áreas de mata e áreas abertas (dossel médio 15 m, (Develey, 2004)) não são tão grandes quanto na Amazônia, onde há dossel de 30 a 40 m (Laurance et al., 2004a; Laurance et al., 2004b). Mas nossas previsões foram contrariadas, uma vez que a comunidade de aves foi fortemente influenciada por efeitos de borda (Capítulo 3).

Devido ao padrão agregado de cobertura florestal nas áreas de Tapiraí e Jurupará, não foram encontrados locais propícios para a avaliação dos efeitos de borda entre matas primárias contínuas e áreas abertas. Por causa desta limitação e pela falta de outros estudos sobre efeitos de borda conduzidos em áreas contínuas e primárias na Mata Atlântica, aqui se pode apenas fazer uma comparação com os estudos conduzidos na Amazônia. Mas ainda é interessante mostrar que, apesar de nos fragmentos florestais ter sido encontrada uma comunidade de aves menos íntegra que na paisagem contínua 
adjacente (Anexo II), os efeitos de borda ainda foram tão fortes quanto os observados para áreas da Amazônia (Restrepo \& Gomez, 1998; Laurance, 2004), o que mostra que alguns dos padrões já bem estabelecidos para matas primárias podem ser extrapolados para áreas de mata secundária.

Qual a interação entre efeitos de borda e de área de fragmento?

Outro fator que complica a detecção de efeitos de borda é o fato de que o presente estudo foi conduzido em uma paisagem fragmentada. Por causa dos efeitos múltiplos de borda (Malcolm, 1994) e da interação entre efeitos de área e de borda (Ewers et al., 2007), fragmentos pequenos dificilmente possuem áreas não impactadas pelos efeitos de borda (Laurance \& Yensen, 1991). Desta forma, é esperado que se encontre pouca diferença entre a comunidade das bordas e a do interior dos fragmentos. De fato, nossos resultados mostram que fragmentos de tamanho mediano (10 a 40 ha) não mostram grande diferença entre a comunidade de aves das bordas e dos interiores; no entanto, uma diferença bem mais acentuada foi encontrada em fragmentos de 90 a 140 ha (Capítulo 3, Fig. 3). Mas talvez ainda mais interessante é o fato, que a comunidade de aves na Mata Atlântica é afetada da mesma maneira por efeito de bordas e por diminuição da área do fragmento (Capítulo 3, Fig. 2); ou seja, as espécies que são afetadas negativamente em áreas de borda são as mesmas que desaparecem em fragmentos pequenos, e da mesma maneira, espécies afetadas positivamente por efeitos de borda são também beneficiadas pela redução na área do fragmento (Capítulo 3, Fig. 5).

Contudo, uma vez que efeitos de área de fragmento e efeitos de borda são altamente correlacionados é difícil dizer se as espécies são afetadas pela redução em área ou pelos efeitos das múltiplas bordas. Para controlar esta correlação e obter dados 
mais precisos sobre a influência independente da área do fragmento, Fletcher et al. (2007) sugerem que os pontos amostrais estejam sempre à mesma distância da borda, ou que este controle seja feito estatisticamente. No estudo apresentado no Capítulo 3, ambas as formas de controle foram feitas, e em ambos os casos a área do fragmento deixou de ser uma variável importante quando o efeito de borda foi fixado. Estes resultados dão maior peso a sugestões prévias de que uma grande parte dos efeitos de área de fragmento encontrados para paisagens fragmentadas possa ser, na verdade, determinada por efeitos de borda (Ewers et al., 2007; Fletcher et al., 2007); o que sugere que em Biologia da Conservação não se deve focar apenas na preservação de áreas maiores, mas também se deve trabalhar para diminuir os efeitos de borda. Estes resultados também auxiliam na melhor compreensão das diferenças teóricas da relação espécie-área formulada pela Teoria de Biogeografia de Ilhas (MacArthur \& Wilson, 1967) e aquela existente em paisagens fragmentadas pelo homem (Ewers \& Didham, 2006; Laurance, 2008).

A falta de borda entre áreas contínuas e abertas que apresentassem condições adequadas para analisar a influência de efeitos de borda impõe, no entanto, uma limitação: não foi possível fixar os efeitos de área para se testar os efeitos independentes de borda. Como citado no Capítulo 4, sempre que duas variáveis são altamente correlacionadas e há a tentativa de se avaliar a importância relativa entre elas, é crucial que se controle a correlação para ambos os lados; em outras palavras, neste caso seria importante verificar os efeitos de área controlando os efeitos de borda e vice-versa. Apesar de, neste estudo, não ter sido possível controlar os efeitos de área para checar os efeitos independentes de borda, esta análise foi feita indiretamente por todos os estudos em que se avaliou a distância máxima de penetração dos efeitos de borda em áreas contínuas, ou seja, fixando o efeito de área (Restrepo \& Gomez, 1998; Laurance, 2004; 
Ewers et al., 2007; Ewers \& Didham, 2008; Laurance, 2008). Portanto, hoje há uma extensa literatura existente mostrando que, apesar de haver vários moduladores de efeitos de borda (Capítulo 2), efeitos de área jamais poderiam originar os efeitos de borda.

Como as aves são afetadas pela perda de habitat na escala da paisagem, configuração de fragmentos e estrutura do habitat na escala local?

Assim como os efeitos de área e de borda são altamente correlacionados, a fragmentação e perda de habitat também o são. Na medida em que uma área passa a ser modificada para uso humano, o processo de fragmentação ocorre concomitantemente ao de perda de área. Ainda, por conta do dinamismo em paisagens alteradas pela ação humana (Teixeira et al., 2009; Metzger et al., 2009) e dos efeitos de borda na vegetação (Laurance et al., 2007; Santos et al., 2008; Tabarelli et al., 2008; Oliveira et al., 2008), torna-se também bastante difícil separar os efeitos da modificação da estrutura da vegetação (e.g. qualidade do habitat), dos da fragmentação e perda de habitat, pois todas estas variáveis são fortemente correlacionadas. Além de ocorrerem concomitantemente, a influência da perda, fragmentação e qualidade do habitat também ocorrem principalmente em escalas distintas. A perda afeta as aves na escala da paisagem, enquanto que mudanças no tamanho e na forma do fragmento afetam as aves na escala na mancha, e a qualidade do habitat (i.e. na estrutura da vegetação) afetam aves em escalas mais locais (Cushman \& McGarigal, 2003). Por serem escalas espacialmente hierárquicas, a questão da correlação entre as variáveis se torna ainda mais complexa, pois fica explicito que uma variável faz parte da outra.

A influência das mudanças na perda de habitat, da configuração do fragmento florestal, e da qualidade do habitat tem sido há tempos considerada de suma importância para a comunidade de aves (Trzcinski et al., 1999; Villard et al., 1999; Sekercioglu et 
al., 2002; Pearman, 2002; Cushman \& McGarigal, 2002; Cushman \& McGarigal, 2004; Ferraz et al., 2007; Barlow et al., 2007; Martensen et al., 2008). No entanto, devido à natureza altamente correlacionada destas variáveis, torna-se difícil distinguir estatisticamente a importância relativa entre elas. Dada a complexidade desta questão, no capítulo 4 foram usadas técnicas estatísticas para avaliar explicitamente a correlação entre os efeitos da perda de habitat na escala da paisagem, da configuração do fragmento na escala da mancha e da qualidade do habitat na escala local. Os resultados mostram que, em conjunto, as variáveis representando estas três escalas explicam uma porcentagem surpreendentemente grande da variação em riqueza de espécies, abundância de indivíduos e composição da comunidade (Capítulo 4, Tabela 1). Por exemplo, tanto a riqueza quanto a abundância de espécies sensíveis tiveram aproximadamente $92 \%$ de sua variação explicada pelo conjunto destas três escalas, e resultados semelhantes foram encontrados para a composição da comunidade. Porém, a análise de partição de variância mostrou que a correlação existente entre as variáveis é tão grande que seus efeitos dificilmente podem ser separados, e apenas com estes resultados não seria possível apontar quais variáveis são as melhores preditoras da comunidade. Contudo, é importante notar que o grau de contribuição partilhada e única variou conforme a variável resposta (Capítulo 4, Tabela 1), e esta variação foi capturada pelos modelos de equação estrutural de forma que foi possível montar o modelo mais parsimonioso que melhor explicasse a variação na abundância e riqueza de cada guilda (Capítulo 4, Tabela 2).

Qual a importância da escala para detectar variações na comunidade de aves?

Os resultados do Capítulo 4 foram, de forma geral, corroborados pelos resultados obtidos no Anexo I, onde em vez de se ter analisado apenas uma região, 
foram analisadas as três regiões de estudo. A composição da comunidade mostrou uma forte variação desde as regiões mais preservadas até os menores fragmentos da paisagem com menor quantidade de mata (Ribeirão Grande - 10\% de mata), refletindo a substituição de espécies sensíveis por espécies generalistas. Os resultados mostram que a comunidade de aves nos fragmentos grandes de Tapiraí (50\% de cobertura florestal) é mais semelhante à encontrada em áreas de mata secundária contínua, enquanto que os fragmentos médios e pequenos de Tapiraí são mais semelhantes aos fragmentos grandes de Caucaia (30\% de cobertura florestal). O mesmo padrão ocorre em Caucaia, onde os fragmentos grandes possuem uma comunidade diferente daquela encontrada nos fragmentos médios e pequenos, que por sua vez são mais semelhantes aos fragmentos grandes de Ribeirão Grande (10\% de cobertura florestal) (Anexo I, Fig. 1). Apesar de, no geral, haver muitas similaridades entre os resultados do Capítulo 4 e Anexo I, houve uma diferença marcante. A análise da qualidade do habitat na escala da paisagem (paisagens contínuas com diferentes graus de perturbação), ao invés da escala local (parcelas ao redor do ponto amostral), mostrou que a estrutura florestal não afeta somente a guilda das espécies sensíveis, mas também a guilda de espécies generalistas e a composição da comunidade. Resultados como estes reiteram o quanto é importante a escolha da escala espacial correta para avaliar a importância relativa de uma determinada variável, para por fim poder gerar um melhor entendimento de como as espécies são afetadas pelas mudanças nos habitats naturais (Gardner et al., 2009).

Na mesma região de estudo, Bueno (2008) também avaliou a importância da perda, fragmentação e qualidade de habitats para as espécies de pequenos mamíferos, mas esta autora encontrou padrões bastante diferentes. Ao analisar a riqueza e abundância de espécies endêmicas de pequenos mamíferos, Bueno (2008) observou um forte efeito de perda de habitat na escala da paisagem para ambas as variáveis, mas o 
efeito de tamanho de fragmento foi mais fraco e variável (apesar de tamanho de fragmento ter tido forte influência na paisagem com 30\% de cobertura florestal). Na paisagem de Tapiraí também foi encontrado que os pequenos mamíferos não são afetados por efeitos de borda (Naxara, 2008) e que grandes mamíferos são mais influenciados pela proximidade de estradas e presença de cachorros domésticos do que por perda de habitat (Espartosa, 2009).

É interessante que estudando a mesma paisagem e os mesmos fragmentos, foram encontradas diferenças tão marcantes na resposta das espécies. Na paisagem de Tapiraí, onde a perda de habitat causou declínios drásticos na riqueza de espécies sensíveis $\left(R^{2}=\right.$ 0.84, Capítulo 4), estas mesmas variáveis afetaram positivamente a riqueza de espécies generalistas $\left(R^{2}=0.68\right.$, Capítulo 4$)$, e foram fracas preditoras da ocorrência de espécies de grandes mamíferos (Espartosa, 2009); sendo que padrões semelhantes foram encontrados para os efeitos da fragmentação e qualidade do habitat. Esta variabilidade no comportamento inter-específico gera uma grande dificuldade de extrapolação dos resultados, assim como na elaboração de práticas conservacionistas que sejam adequadas para toda a biota e não apenas para um grupo de organismos. No entanto, como visto no Capítulo 5, esta variabilidade comportamental não está restrita a espécies de diferentes táxons.

\section{O protocolo de amostragem afeta os padrões ecológicos observados?}

No Capítulo 5 foi avaliado se há variação na taxa de captura de indivíduos ao longo do dia, entre estações do ano e entre diferentes anos. Foi aqui encontrada uma grande variabilidade temporal na forma como a riqueza de espécies da mesma assembléia, composta pelos mesmos indivíduos, é afetada pela perda de área (Capítulo 5, Fig. 5). Variações na taxa de captura ao longo do tempo no mesmo local são primordialmente relacionadas à movimentação de indivíduos, que é influenciada pelo comportamento, 
disponibilidade de recursos, temperatura, entre outros (Eyster, 1954; Karr, 1981; Remsen \& Good, 1996; Develey \& Peres, 2000). Estas variações são bem conhecidas e até mesmo esperadas, porém os resultados obtidos mostram que estas variações podem também influenciar as estimativas de riqueza de espécies e composição da comunidade e por fim levar a resultados díspares da importância da perda de área para a comunidade de aves. Existe uma extensa literatura a respeito da influência do esforço amostral tanto nas estimativas de riqueza de espécies quanto na relação espécie-área (Mac Nally, 1997; Link \& Sauer, 2007; Molokwu et al., 2008; Elphick, 2008; Borges et al., 2009; McGlinn \& Palmer, 2009; Chapman \& Underwood, 2009; Chao et al., 2009), porém o que neste capítulo é discutido é que as diferenças encontradas se devem muito mais à variação temporal no uso de habitat pelas aves do que por influência puramente metodológica do esforço amostral. Se tivesse sido amostrado apenas o período da manhã, e o protocolo temporal tivesse sido mantido, os resultados obtidos com estas 240 horas-rede teriam sido os mesmos que os encontrados com 680 horas-rede (i.e. um dia e meio de amostragem durante dois períodos secos e dois períodos chuvosos, ao longo de dois anos). Enquanto que se tivessem sido amostrados apenas um dia e meio em uma dada estação (170 horas-rede) ou apenas os períodos chuvosos (340 horasrede), a chance de encontrar padrões significativos na relação espécie-área teria sido bem mais baixa. Estes resultados alertam para o fato de que é importante tomar cuidado com os dados obtidos em amostragens de curta duração, como as praticadas em EIA/RIMA, pois resultados incorretos sobre padrões ecológicos podem levar a estratégias conservacionistas inadequadas.

Quais são os melhores indicadores das mudanças na integridade da comunidade? Até agora todos os resultados discutidos dos capítulos 3 a 5, e Anexo I, apontam para um mesmo padrão geral. A comunidade de aves de sub-bosque é fortemente 
influenciada pela perda de habitat, pela configuração dos fragmentos e qualidade do habitat, porém a forma como esta influência se dá varia entre espécies, entre guildas, ao longo do tempo e em diferentes contextos espaciais. Até mesmo a perda de habitat que é considerada a única variável com resultados consistentes e negativos (Fahrig, 2003), mostrou ter influência variável na riqueza de espécies e abundância de indivíduos dependendo do grupo analisado (Capítulo 4, Anexo I). Esta variação é, no entanto, esperada, pois comunidades naturais são formadas por espécies com características e requerimentos biológicos muito distintos (Gardner et al., 2009); e é apenas ao se ter uma visão mais holística da variação da composição da comunidade total que se percebe que existe um gradiente único de variação na composição da comunidade de aves em áreas alteradas pela ação humana (Capítulo 6, Fig. S1). Na medida em que matas primárias se tornam secundárias, áreas contínuas são fragmentadas, o tamanho dos fragmentos diminui e os efeitos de borda se tornam mais evidentes, dá-se uma substituição graduada e unidirecional de espécies sensíveis por espécies generalistas (Capítulo 3, Capítulo 6 - Fig. S1, Anexo 1). Ao contrário das análises de riqueza e abundância por grupo, a alteração na composição da comunidade em paisagens alteradas pela ação humana, ou seja, a perda de integridade na composição da comunidade de aves é forte, consistente e previsível.

Com resultados como estes, não é surpreendente que não tenha sido encontrada grande eficiência no uso de indicadores biológicos. Por outro lado, a eficiência do uso de indicadores formados por métricas da paisagem para identificar áreas com maior integridade da composição da comunidade gera uma grande perspectiva na aplicação destes indicadores. Afinal, em todas as paisagens foi encontrada forte correlação entre as métricas da paisagem e a variação na composição da comunidade (observado também no Capítulo 4 com apenas duas variáveis), enquanto que a eficiência do uso de espécies 
indicadoras foi permeada por problemas metodológicos e diferenças biológicas entre espécies.

O uso de métricas indicadoras se mostrou vantajoso, pois além do forte poder preditivo dos modelos, estes ainda possuíam grande capacidade de extrapolação para demais paisagens e escalas, de forma que foi encontrada baixa variação na eficiência desta estratégia. O uso de espécies indicadoras, por outro lado, mostrou ter eficiência muito variável e dependente do contexto. De fato, em algumas situações, o índice escolhido para selecionar as espécies indicadoras ("Umbella Index”; Fleishman et al., 2000) não foi muito eficiente e, por vezes, espécies consideradas boas indicadoras para uma paisagem nem ocorreram nas demais paisagens (Capítulo 6). No entanto, é possível que espécies indicadoras tivessem resultados mais consistentes que métricas da paisagem caso outros grupos taxonômicos tivessem sido utilizados. Em Tapiraí, por exemplo, encontrou-se que as espécies de anfíbios são também afetadas pela perda de habitat e fragmentação, porém há forte influência de variáveis de micro-habitat relacionadas à sua reprodução, como distância de corpos d’água (Condez, 2008). O poder explicativo dos modelos para anfíbios foi baixo, sugerindo que muitas das variáveis que afetam estas espécies não foram medidas por serem desconhecidas. Ou seja, em casos onde a biologia das espécies não é bem conhecida, ou em que haja a dificuldade de criar modelos com variáveis ambientais que possuam um alto poder explicativo, é provável que o uso de espécies indicadoras seja mais eficiente do que o de métricas indicadoras.

Os dados obtidos para o projeto no qual esta tese se insere (Metzger, 2006) mostram que as mudanças nos habitats de Mata Atlântica causadas pela ação humana levam à perda de espécies de diversos táxons (Pardini et al., 2005; Bragagnolo et al., 2007; Umetsu \& Pardini, 2007; Martensen et al., 2008; Bueno, 2008; Naxara, 2008; 
Condez, 2008; Metzger et al., 2009; Espartosa, 2009), perda de diversidade genética (Dixo et al., 2009), redução na capacidade de imigração e emigração de indivíduos entre fragmentos (Uezu et al., 2005; Umetsu et al., 2008; Boscolo et al., 2008; Awade \& Metzger, 2008; Hansbauer et al., 2008a; Hansbauer et al., 2008b), entre outras alterações. Ou seja, o uso de métricas indicadoras parece ser a forma mais simples, rápida e prática de se avaliar a importância de áreas para a conservação considerando que: (i) as mudanças nos habitats naturais levam à perda de integridade das comunidades; (ii) amostragens de curta duração produzem resultados pouco consistentes; (iii) as mudanças nos habitats causadas pela ação humana são em geral fortemente correlacionadas (de forma que não é necessário medir todas as variáveis para se obter um bom poder explicativo); e (iv) que a obtenção de métricas da paisagem é muito mais fácil e rápida do que a condução de trabalho de campo para se obter dados biológicos.

\section{Implicações conservacionistas}

Os resultados no Anexo I mostram que houve uma perda significativa na integridade da comunidade em todas as paisagens com alto grau de perturbação humana (matas contínuas secundárias e paisagens fragmentadas) (Anexo I - Fig, 1), de forma que em todos estes locais seriam necessários esforços de restauração para re-estabelecer a integridade da comunidade. Porém, a estratégia mais adequada de restauração varia conforme o contexto. Em paisagens bastante florestadas, com alto grau de conectividade entre os fragmentos, e que possuem as condições necessárias para a ocorrência de espécies sensíveis, a melhor forma de manejo seria de trabalhar para reduzir os efeitos de borda, uma vez que estas espécies são altamente afetadas pela presença de borda (Capítulo 3). No outro extremo, em paisagens com alto grau de distúrbio como a de Ribeirão Grande (10\% cobertura florestal) é prioritário que se trabalhe para aumentar a 
quantidade de mata na paisagem e que se crie corredores com áreas florestas adjacentes, permitindo assim a re-colonização de espécies extintas localmente. Já na paisagem de Caucaia (30\% de cobertura florestal) há maior flexibilidade de conservação, pois tanto o aumento de cobertura florestal como o manejo para redução dos efeitos de borda poderão trazer conseqüências favoráveis. A partir destes resultados muitas outras perguntas ainda são geradas, como: qual é o máximo de perda de habitat que se pode ter para se manter os serviços ecossistêmicos mínimos necessários? Quantas e quais espécies podem ser perdidas sem perder a funcionalidade do ecossistema? Porém, a resposta para estas questões está além do escopo desta tese.

Em conclusão, esta tese mostra que apesar do contexto espacial e temporal influir bastante na forma como as aves são afetadas pela perda, fragmentação e qualidade do habitat; em geral, estas mudanças nos habitats causadas pela ação humana afetam a comunidade de aves de sub-bosque de forma forte e consistente. Devido ao alto poder explicativo, e alto grau de correlação entre as variáveis ambientais que representam as mudanças nos habitats naturais, com poucas métricas de paisagem é possível montar modelos robustos que podem ser usados, em diferentes contextos de paisagem, para a escolha das estratégias mais eficientes para se conservar as aves de Mata Atlântica. 


\section{Bibliografia}

Awade, M. \& Metzger, J. P. (2008) Using gap-crossing capacity to evaluate functional connectivity of two Atlantic rainforest birds and their response to fragmentation. Austral Ecology, 33, 863-871.

Baldi, A. (1996) Edge effects in tropical versus temperate forest bird communities: three alternative hypotheses for the explanation of differences. Acta Zoologica Academiae Scientiarum Hungaricae, 42, 163-172.

Barlow, J., Mestre, L. A. M., Gardner, T. A., \& Peres, C. A. (2007) The value of primary, secondary and plantation forests for Amazonian birds. Biological Conservation, 136, 212-231.

Borges, P. A. V., Hortal, J., Gabriel, R., \& Homem, N. (2009) Would species richness estimators change the observed species area relationship? Acta Oecologica, 35, 149156.

Boscolo, D., Candia-Gallardo, C., Awade, M., \& Metzger, J. P. (2008) Importance of interhabitat gaps and stepping-stones for lesser woodcreepers (Xiphorhynchus fuscus) in the Atlantic Forest, Brazil. Biotropica, 40, 273-276.

Bragagnolo, C., Nogueira, A. A., Pinto-da-Rocha, R., \& Pardini, R. (2007) Harvestmen in an Atlantic forest fragmented landscape: Evaluating assemblage response to habitat quality and quantity. Biological Conservation, 139, 389-400.

Bueno, A. A. (2008) Pequenos mamíferos da Mata Atlântica do Planalto Atlântico Paulista: uma avaliação da ameaça de extinção e da resposta a alteração no contexto e tamanho dos remanescentes. Tese de Doutorado. Universidade de São Paulo, São Paulo.

Cadenasso, M. L. \& Pickett, S. T. A. (2001) Effect of edge structure on the flux of species into forest interiors. Conservation Biology, 15, 91-97.

Chao, A., Colwell, R. K., Lin, C. W., \& Gotelli, N. J. (2009) Sufficient sampling for asymptotic minimum species richness estimators. Ecology, 90, 1125-1133.

Chapman, M. G. \& Underwood, A. J. (2009) Evaluating accuracy and precision of species-area relationships for multiple estimators and different marine assemblages. Ecology, 90, 754-766.

Condez, T. H. (2008) Efeitos da fragmentação da floresta na diversidade e abundância de anfíbios anuros e lagartos de serapilheira em uma paisagem do Planalto Atlântico de São Paulo. Tese de Doutorado. Universidade de São Paulo, São Paulo.

Cushman, S. \& McGarigal, K. (2004) Hierarchical analysis of forest bird speciesenvironment relationships in the Oregon coast range. Ecological Applications, 14, 1090-1105.

Cushman, S. A. \& McGarigal, K. (2002) Hierarchical, multi-scale decomposition of species-environment relationships. Landscape Ecology, 17, 637-646. 
Cushman, S. A. \& McGarigal, K. (2003) Landscape-level patterns of avian diversity in the Oregon coast range. Ecological Monographs, 73, 259-281.

Develey, P. F. (2004) Efeitos da fragmentação e do estado de conservação da floresta na diversidade de aves de Mata Atlântica. Tese de Doutorado. Universidade de São Paulo, São Paulo.

Develey, P. F. \& Peres, C. A. (2000) Resource seasonality and the structure of mixed species bird flocks in a coastal Atlantic forest of southeastern Brazil. Journal of Tropical Ecology, 16, 33-53.

Dixo, M., Metzger, J. P., Morgante, J. S., \& Zamudio, K. R. (2009) Habitat fragmentation reduces genetic diversity and connectivity among toad populations in the Brazilian Atlantic Coastal Forest. Biological Conservation in press.

Elphick, C. S. (2008) How you count counts: the importance of methods research in applied ecology. Journal of Applied Ecology, 45, 1313-1320.

Espartosa, K. D. (2009) Mamíferos terrestres de maior porte e a invasão de cães domésticos em remanescentes de uma paisagem fragmentada de Mata Atlântica: avaliação da eficiência de métodos de amostragem e da importância de múltiplos fatores sobre a distribuição das espécies. Tese de Doutorado. Universidade de São Paulo, São Paulo.

Ewers, R. M. \& Didham, R. K. (2006) Confounding factors in the detection of species responses to habitat fragmentation. Biological Reviews, 81, 117-142.

Ewers, R. M. \& Didham, R. K. (2008) Pervasive impact of large-scale edge effects on a beetle community. Proceedings of the National Academy of Sciences of the United States of America, 105, 5426-5429.

Ewers, R. M., Thorpe, S., \& Didham, R. K. (2007) Synergistic interactions between edge and area effects in a heavily fragmented landscape. Ecology, 88, 96-106.

Eyster, M. B. (1954) Quantitative measurement of the influence of photoperiod, temperature, and season on the activity of captive songbirds. Ecological Monographs, 24, 1-28.

Fahrig, L. (2003) Effects of habitat fragmentation on biodiversity. Annual Review of Ecology, Evolution and Systematics, 34, 487-515.

Ferraz, G., Nichols, J. D., Hines, J. E., Stouffer, P. C., Bierregaard, R. O., Jr., \& Lovejoy, T. E. (2007) A large-scale deforestation experiment: effects of patch area and isolation on Amazon birds. Science, 315, 238-241.

Fleishman, E., Murphy, D. D., \& Brussard, P. E. (2000) A new method for selection of umbrella species for conservation planning. Ecological Applications, 10, 569-579.

Fletcher, R. J., Ries, L., Battin, J., \& Chalfoun, A. D. (2007) The role of habitat area and edge in fragmented landscapes: definitively distinct or inevitably intertwined? Canadian Journal of Zoology, 85, 1017-1030. 
Gardner, T. A., Barlow, J., Chazdon, R. L., Ewers, R. M., Harvey, C. A., Peres, C. A., \& Sodhi, N. S. (2009) Prospects for tropical forest biodiversity in a human-modified world. Ecology Letters, 12.

Hansbauer, M. M., Storch, I., Leu, S., Nieto-Holguin, J. P., Pimentel, R. G., Knauer, F., \& Metzger, J. P. (2008a) Movements of neotropical understory passerines affected by anthropogenic forest edges in the Brazilian Atlantic rainforest. Biological Conservation, 141, 782-791.

Hansbauer, M. M., Storch, I., Pimentel, R. G., \& Metzger, J. P. (2008b) Comparative range use by three Atlantic Forest understorey bird species in relation to forest fragmentation. Journal of Tropical Ecology, 24, 291-299.

Imbeau, L., Drapeau, P., \& Monkkonen, M. (2003) Are forest birds categorised as "edge species" strictly associated with edges? Ecography, 26, 514-520.

Karr, J. R. (1981) Surveying birds with mist nets. Studies in Avian Biology, 6, 62-67.

Laurance, S. G. W. (2004) Responses of understory rain forest birds to road edges in Central Amazonia. Ecological Applications, 14, 1344-1357.

Laurance, S. G. W., Stouffer, P. C., \& Laurance, W. E. (2004a) Effects of road clearings on movement patterns of understory rainforest birds in central Amazonia. Conservation Biology, 18, 1099-1109.

Laurance, W. F. (2008) Theory meets reality: how habitat fragmentation research has transcended island biogeographic theory. Biological Conservation, 141, 1731-1744.

Laurance, W. F., Oliveira, A. A., Laurance, S. G., Condit, R., Nascimento, H. E. M., Sanchez-Thorin, A. C., Lovejoy, T. E., Andrade, A., D'Angelo, S., Ribeiro, J. E., \& Dick, C. W. (2004b) Pervasive alteration of tree communities in undisturbed Amazonian forests. Nature, 428, 171-175.

Laurance, W. F. \& Yensen, E. (1991) Predicting the impacts of edge effects in fragmented habitats. Biological Conservation, 55, 77-92.

Laurance, W. F., Nascimento, H. E. A. M., Laurance, S. G. W., Andrade, A., Ewers, R. M., Harms, K. E., Luizao, R. C., \& Ribeiro, J. E. L. S. (2007) Habitat fragmentation, variable edge effects, and the landscape-divergence hypothesis. PLoS ONE, 2, e1017.

Leopold, A. (1933) Game management. Charles Scribner's Sons, New York.

Lindell, C. A., Riffell, S. K., Kaiser, S. A., Battin, A. L., Smith, M. L., \& Sisk, T. D. (2007) Edge responses of tropical and temperate birds. Wilson Journal of Ornithology, 119, 205-220.

Link, W. A. \& Sauer, J. R. (2007) Seasonal components of avian population change: joint analysis of two large-scale monitoring programs. Ecology, 88, 49-55.

Mac Nally, R. (1997) Monitoring forest bird communities for impact assessment: the influence of sampling intensity and spatial scale. Biological Conservation, 82, 355367. 
MacArthur, R. H. \& Wilson, E. O. (1967) The theory of island biogeography. Princeton University Press, Princeton.

Malcolm, J. R. (1994) Edge effects in Central Amazonian forest fragments. Ecology, 75, 2438-2445.

Martensen, A. C., Pimentel, R. G., \& Metzger, J. P. (2008) Relative effects of fragment size and connectivity on bird community in the Atlantic Rain Forest: Implications for conservation. Biological Conservation, 141, 2184-2192.

McGlinn, D. J. \& Palmer, M. W. (2009) Modeling the sampling effect in the speciestime-area relationship. Ecology, 90, 836-846.

Metzger, J. P. (2006) Conservação da Biodiversidade em Paisagens Fragmentadas no Planalto Atlântico de São Paulo - II. Projeto de Pesquisa, CNPq, Brasília.

Metzger, J. P., Martensen, A. C., Dixo, M., Bernacci, L. C., Ribeiro, M. C., Teixeira, A. M. G., \& Pardini, R. (2009) Time-lag in biological responses to landscape changes in a highly dynamic Atlantic forest region. Biological Conservation, 142, 1166-1177.

Molokwu, M. N., Olsson, O., Nilsson, J. A., \& Ottosson, U. (2008) Seasonal variation in patch use in a tropical African environment. Oikos, 117, 892-898.

Murcia, C. (1995) Edge effects in fragmented forests - Implications for conservation. Trends in Ecology \& Evolution, 10, 58-62.

Naxara, L. (2008) Importância dos corredores ripários para a fauna - pequenos mamíferos em manchas de floresta, matriz do entorno e elementos lineares em uma paisagem fragmentada de Mata Atlântica. Tese de Doutorado. Universidade de São Paulo, São Paulo.

Oliveira, M. A., Santos, A. M. M., \& Tabarelli, M. (2008) Profound impoverishment of the large-tree stand in a hyper-fragmented landscape of the Atlantic forest. Forest Ecology and Management, 256, 1910-1917.

Pardini, R., de Souza, S. M., Braga-Neto, R., \& Metzger, J. P. (2005) The role of forest structure, fragment size and corridors in maintaining small mammal abundance and diversity in an Atlantic forest landscape. Biological Conservation, 124, 253-266.

Pearman, P. B. (2002) The scale of community structure: Habitat variation and avian guilds in tropical forest understory. Ecological Monographs, 72, 19-39.

Prugh, L. R., Hodges, K. E., Sinclair, A. R. E., \& Brashares, J. S. (2008) Effect of habitat area and isolation on fragmented animal populations. Proceedings of the National Academy of Sciences, 105, 20770-20775.

Remsen, J. V. \& Good, D. A. (1996) Misuse of data from mist-net captures to assess relative abundance in bird populations. Auk, 113, 381-398.

Restrepo, C. \& Gomez, N. (1998) Responses of understory birds to anthropogenic edges in a Neotropical montane forest. Ecological Applications, 8, 170-183. 
Restrepo, C., Gomez, N., \& Heredia, S. (1999) Anthropogenic edges, treefall gaps, and fruit-frugivore interactions in a neotropical montane forest. Ecology, 80, 668-685.

Ries, L., Fletcher, R. J., Jr., Battin, J., \& Sisk, T. D. (2004) Ecological responses to habitat edges: mechanisms, models and variability explained. Annual Review of Ecology, Evolution and Systematics, 35, 491-522.

Ries, L. \& Sisk, T. D. (2004) A predictive model of edge effects. Ecology, 85, 29172926.

Santos, B. A., Peres, C. A., Oliveira, M. A., Grillo, A., Alves-Costa, C. P., \& Tabarelli, M. (2008) Drastic erosion in functional attributes of tree assemblages in Atlantic forest fragments of northeastern Brazil. Biological Conservation, 141, 249-260.

Sekercioglu, C. H., Ehrlich, P. R., Daily, G. C., Aygen, D., Goehring, D., \& Sandi, R. F. (2002) Disappearance of insectivorous birds from tropical forest fragments. Proceedings of the National Academy of Sciences, 99, 263-267.

Tabarelli, M., Lopes, A. V., \& Peres, C. A. (2008) Edge-effects drive tropical forest fragments towards an early-successional system. Biotropica, 40, 657-661.

Teixeira, A. M., Soares-Filho, B. S., Freitas, S. R., \& Metzger, J. P. (2009) Modeling landscape dynamics in an Atlantic Rainforest region: Implications for conservation. Forest Ecology and Management, 257, 1219-1230.

Trzcinski, M. K., Fahrig, L., \& Merriam, G. (1999) Independent effects of forest cover and fragmentation on the distribution of forest breeding birds. Ecological Applications, 9, 586-593.

Uezu, A., Metzger, J. P., \& Vielliard, J. M. E. (2005) Effects of structural and functional connectivity and patch size on the abundance of seven Atlantic Forest bird species. Biological Conservation, 123, 507-519.

Umetsu, F., Metzger, J. P., \& Pardini, R. (2008) Importance of estimating matrix quality for modeling species distribution in complex tropical landscapes: a test with Atlantic forest small mammals. Ecography, 31, 359-370.

Umetsu, F. \& Pardini, R. (2007) Small mammals in a mosaic of forest remnants and anthropogenic habitats-evaluating matrix quality in an Atlantic forest landscape. Landscape Ecology, 22, 517-530.

Villard, M. A. (1998) On forest-interior species, edge avoidance, area sensitivity, and dogmas in avian conservation. The Auk, 115, 801-805.

Villard, M. A., Trzcinski, M. K., \& Merriam, G. (1999) Fragmentation effects on forest birds: relative influence of woodland cover and configuration on landscape occupancy. Conservation Biology, 13, 774-783. 
Anexo I 


\section{Dual-scale forest restoration options for Atlantic Forest}

Cristina BANKS-LEITE, Robert M. EWERS, Alexandre MARTENSEN \& Jean Paul METZGER $^{1}$

The combined effects of deforestation, forest fragmentation and forest degradation are driving species to the brink of extinction across the world's tropical zones. One of the most extreme examples is the Atlantic Forest, reduced in extent by nearly $90 \%$ and where an endemic and diverse avifauna must now persist in a region that is home to 150 million people whilst much of the extant forest is second growth and distributed in patches of less than 100 ha. Remarkably, very few species have been driven extinct from this biome, yet many are highly threatened $(1,2)$ and may yet be committed to extinction over the coming decades $(1,2)$ unless precise conservation measures are undertaken. In such a heavily deforested and populated area, the key to successful conservation will be to generate the maximum beneficial impact from the minimum amount of forest restoration. Two alternative strategies present themselves: increase the size of existing forest patches or work directly towards landscape-scale forest mosaics.

To determine which restoration strategy will be most effective, we sampled 7295 forest understory birds from 140 species using mist nets in 65 sites of Brazilian Atlantic Forest varying in size from 2-200 ha, with the range of patch sizes replicated in three 10,000 ha landscapes that have suffered 50, 70 and $90 \%$ forest loss respectively (3). Each landscape was paired with an adjacent control landscape retaining $90 \%$ forest cover, although these varied in their disturbance history (3). Bird community composition changed consistently with vegetation disturbance, patch size and landscape forest cover (Fig. 1). Control landscapes impacted just by selective logging had a community composition considerably more pristine than clear-cut continuous forest. In all fragmented landscapes, large patches had a community more reminiscent of continuous forests than small patches, and the slope of that relationship was the same across the patch size gradient in all landscapes (ANCOVA, interaction effect, $F_{2,58}=0.66, P=$ 0.52). However, the intercept of this relationship was altered such that the avifauna in 
large patches embedded in a more deforested landscape was similar to the avifauna in small patches embedded in landscapes with a larger proportion of forest.

A similar pattern held when we distinguished disturbance-sensitive from habitatgeneralist birds. Disturbance-sensitive species were invariably more prevalent in large than in small patches, but regardless of patch size, were more speciose in more forested landscapes. Even within the three intact landscapes, disturbance-sensitive species showed a dramatic response to the history of forest use: old growth landscapes supported, on average, two times the number of forest-specialist species than old growth forest that had been logged, and nearly five times the number of disturbance-sensitive species than continuous second-growth forest. Across the gradient from continuous old-growth to small patches in highly deforested landscapes, disturbance-sensitive species were replaced with habitat-generalists, showing how deforestation and forest fragmentation precipitates a turnover from the unique and specialized avifauna of Atlantic Forests to a generalist community of cosmopolitan species. Consequently, it appears certain that a proliferation of regrowth will be unable to compensate for the losses of the most specialized species resulting from ongoing conversion of old growth tropical forest (4).

These striking patterns of patch-scale impacts superimposed onto landscape-scale impacts presents a remarkable opportunity for flexibility in conservation options for one of the world's most severely impacted biodiversity hotspots. In a biome where forest cover is beginning to recover in some areas, our data indicate that similar conservation benefit could be attained by focusing on increasing patch sizes or by increasing landscape forest cover. The distinction is important: it takes more land area to increase forest cover across a landscape than it does to increase the size of a single patch, but in a heavily populated area with highly fragmented patterns of land ownership, it may often be more feasible to restore multiple small patches. However, to restore a community rich in forest-specialist species, the strategy becomes more specific. In landscapes with intermediate deforestation, either an increase in patch size or in landscape forest cover will help recover lost species, whereas in heavily deforested landscapes increases in patch size alone will be ineffectual, as the sensitive species have gone locally extinct, and in low deforestation landscapes the best option is to increase patch size, as the present sensitive species are highly affected by edge effects. 
Eventually, to ensure the survival of this unique suite of species, landscape-scale restoration will be essential and large tracts of old-growth have to be seen as irreplaceable. But in the immediate future, patch-based conservation approaches could be efficiently employed. Having the flexibility of being able to initially choose between patch-based and landscape-based conservation actions greatly enhances the chance that we can avoid paying the impending extinction debt of the endemic Atlantic Forest avifauna.

\section{References}

1. T. Brooks, A. Balmford, Nature 380, 115 (1996).

2. T. Brooks, J. Tobias, A. Balmford, Anim. Conserv. 2, 211 (1999).

3. See Supporting Online Material in Science Online.

4. $\quad$ S. J. Wright, H. C. Muller-Landau, Biotropica 38, 287 (2006).

\section{Figure Legends}

The effect of deforestation on Atlantic Forest understory bird community composition (black), species richness of disturbance-sensitive species (red) and habitat-generalist species (blue). Values are mean $\pm 1 \mathrm{SE}$. Open squares, circles and triangles represent large, medium and small patches respectively; filled squares, circles and triangles represent landscapes with near-continuous forest cover in the form of undisturbed old growth forest, logged old growth forest, and secondary forest respectively. Horizontal lines join categories with no statistically significant difference (Tukeys HSD test). 
Figure 1

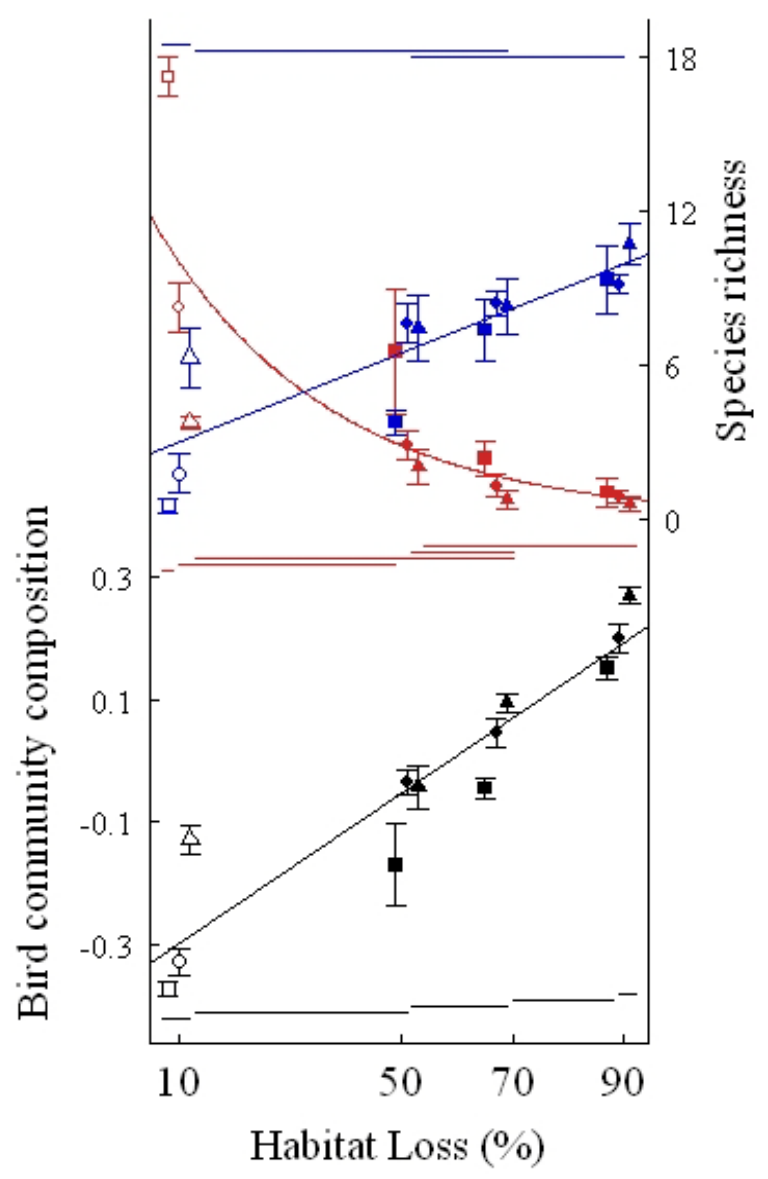




\section{Dual-scale forest restoration options for Atlantic Forest}

Cristina BANKS-LEITE, Robert M. EWERS, Alexandre MARTENSEN \& Jean Paul METZGER

\section{Supplementary Material}

\section{Materials and Methods}

Study sites

Study sites were located in the Atlantic Plateau of the State of São Paulo (Fig. S1). We studied six landscapes of 10,000 ha each, three fragmented (10, 30 and 50\% of forest cover) and three continuous ( $90 \%$ of forest cover). Each fragmented landscape was paired with a nearby continuous landscapes (Capítulo 1, Fig. 1). The fragmented landscapes consist mostly of patches of secondary forest in varying stages of regrowth, croplands and pastures, Pinus and Eucapliptus ssp. plantations and small urban areas. The three continuous landscapes differed in the degree of historical human use. One landscape had been historically subjected to selective logging of hardwood tress and now consists of a highly advanced successional stage, with a species composition and structure approaching that of old-growth forests. The second continuous landscape had a recent history of logging for hardwood trees; however there is no record of clearcutting. The third continuous landscape is known to have been clear-cut to great extent in the past but was left to regenerate around 1900, and is consequently composed almost entirely of second-growth forest.

Land cover classifications for all six landscapes were based on Spot 5 images from 2005, with 10 m resolution. Classified images were analysed in Fragstats 3.3, where landscape cover and patch size metrics were obtained.

\section{Bird sampling}

In each continuous landscape we sampled four sites, and in each fragmented landscape we sampled 17 sites, apart from the 50\% landscape in which 19 patches were sampled. Birds were sampled with the use of mist-nets (12 m length, $2.5 \mathrm{~m}$ height, $31 \mathrm{~mm}$ mesh) 
from 2001 to 2007. All sampling sites were located in areas of similar relief, luminosity and vegetation structure conditions. In total, our sampling effort consisted of 41,444 net-hours (mean $=637$ net-hours per site; SD = 76). All birds were banded and species were indentified in the field and, using published responses to human-disturbances ( $S 1$, 2), we identified species that belonged to two habitat specialization categories, disturbance-sensitive $(S=42)$ and habitat generalist species $(S=44)$.

$\underline{\text { Statistical analyses }}$

To examine patterns of community composition, we used a Principal Coordinates Analyses using a Bray-Curtis dissimilarity index on a abundance matrix standardised (from 0 to 1 ) by species (to reduce the influence of the highly abundant species) and by sites (to control for differences in sampling effort per site). The variation in community composition was mostly explained in the first axis, with the second axis showing a strong horse-shoe effect. Measures of species richness of sensitive species and disturbance-specialist species were controlled for differences in sampling effort and logtransformed for analysis. Patch size was also log-transformed. All analyses were performed using R v.2.7.1 (S3).

\section{References}

S1. D. Stotz, J. W. Fitzpatrick, T. A. Parker III, D. K. Moskovits, Neotropical birds: ecology and conservation (University of Chicago Press, Chicago, 1996).

S2. P. F. Develey, Universidade de São Paulo (2004).

S3. R Development Core Team, R: A language and environment for statistical computing (R Foundation for Statistical Computing, Vienna, 2004). 
Anexo II 
Anexo II - Lista de espécies capturadas na paisagem fragmentada de Tapiraí e área controle contínua, o Parque Estadual de Jurupará. São também apresentados os números de indivíduos capturados no interior dos 19 fragmentos estudados (Interior), das 8 bordas de fragmentos estudadas (Borda), quatro áreas localizadas na paisagem contínua (Controle) e o número total de capturas.

\section{Espécie}

ODONTOPHORIDAE

Odontophorus capueira

ACCIPITRIDAE

Rupornis magnirostris

FALCONIDAE

Micrastur ruficollis

COLUMBIDAE

Leptotila rufaxilla

Leptotila verreauxi

Geotrygon montana

PHAETHORNITHINAE

Ramphodon naevius

Phaethornis eurynome

Phaethornis squalidus

TROCHILINAE

Eupetonema macroura

Florisuga fusca

Chlorostilbon aureoventris

Thalurania glaucops

Leucochloris albicollis

Amazilia versicolor

Amazilia fimbriata

Amazilia lactea

Clytolaema rubricauda

TROGONIDAE

Trogon rufus

MOMOTIDAE

Baryphthengus ruficapillus

BUCCONIDAE

Nonnula rubecula

RAMPHASTIDAE

Ramphastos dicolorus

Selenidera maculirostris

PICIDAE

Picumnus temminckii

Veniliornis spilogaster

Colaptes melanochloros
Interior Borda Controle Total

$\begin{array}{lll}4 & 4 & 8\end{array}$

$\begin{array}{lll}9 & 3 & 12\end{array}$

$\begin{array}{lll}6 & 5 & 11\end{array}$

$\begin{array}{cccc} & & 9 & 9 \\ 54 & 49 & 18 & 121 \\ 2 & 1 & 5 & 8\end{array}$

1

1

3

1

$51 \quad 34$

$6 \quad 6$

23

12

38

$2 \quad 2$

1

2

2

4

3

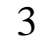

$3 \quad 3$

$1 \quad 1$

1

$1 \quad 1$

$\begin{array}{lll}7 & 2 & 9\end{array}$

$\begin{array}{llll}6 & 2 & 2 & 10\end{array}$

2

\section{2}

1 


\section{Espécie}

THAMNOPHILIDAE

Hypoedaleus guttatus

Batara cinerea

Mackenziana leachii

Thamnophilus caerulescens

Dysithamnus mentalis

Myrmotherula gularis

Myrmotherula minor

Myrmotherula unicolor

Drymophila ochropyga

Drymophila malura

Drymophila squamata

Pyriglena leucoptera

Myrmeciza squamosa

CONOPOPHAGIDAE

Conopophaga lineata

Conopophaga melanops

GRALLARIIDAE

Grallaria varia

RHINOCRYPTIDAE

Scytalopus speluncae

FORMICARIIDAE

Formicarius colma

Chamaeza campanisoma

Chamaeza meruloides

SCLERURIDAE

Sclerurus scansor

DENDROCOLAPTIDAE

Dendrocincla turdina

Sittasomus griseicapillus

Xiphocolaptes albicollis

Dendrocolaptes platyrostris

Xiphorhynchus fuscus

Lepidocolaptes squamatus

FURNARIIDAE

Synallaxis ruficapilla

Synallaxis spixi

Anabacerthia amaurotis

Syndactyla rufosuperciliata

Philydor lichtensteini

Philydor atricapillus

Anabazenops fuscus

Cichlocolaptes leucophrus
Interior Borda Controle Total

$\begin{array}{cccc}6 & & 1 & 1 \\ 1 & 3 & & 9 \\ 9 & 9 & & 1 \\ 58 & 22 & 4 & 18 \\ 14 & 1 & 27 & 42 \\ & & 13 & 13 \\ & & 1 & 1 \\ & & 1 & 1 \\ 1 & 1 & & 2 \\ & & 6 & 6 \\ 89 & 54 & 19 & 162 \\ 14 & 2 & 6 & 22 \\ & & & \\ 108 & 37 & 3 & 148\end{array}$

5

5

1

2

1

39

5

5

49

4

77

30

34

6

20

12

109

17

1

7

24

$\begin{array}{llll}86 & 25 & 14 & 125\end{array}$

12

$\begin{array}{lll}8 & 16 & 24\end{array}$

$1+1$

$\begin{array}{llll}6 & 1 & 3 & 10\end{array}$

$\begin{array}{lll}20 & 7 & 27\end{array}$

$3 \quad 3$

$1 \quad 22 \quad 23$

4

1

(1)

\section{(18}

84

42

13

2

62

2

48

8

5

1

\section{2}

1

1




\section{Espécie}

Automolus leucophthalmus

Lochmias nematura

Heliobletus contaminatus

Xenops minutus

TYRANNIDAE

Mionectes rufiventris

Leptopogon amaurocephalus

Hemitriccus diops

Poecilotriccus plumbeiceps

Tolmomyias sulphurescens

Platyrinchus leucoryphus

Platyrinchus mystaceus

Onychorhynchus coronatus

Myiobius barbatus

Myiobius atricaudus

Lathrotricus euleri

Cnemotriccus fuscatus

Myiodynastes maculatus

Ramphotrigon megacephala

Attila rufus

COTINGIDAE

Carpornis cucullata

Pyroderus scutatus

PIPRIDAE

Ilicura militaris

Manacus manacus

Chiroxiphia caudata

TITYRIDAE

Schiffornis virescens

VIREONIDAE

Cyclarhis gujanensis

Vireo olivaceus

Hylophilus poicilotis

TROGLODYTIDAE

Troglodytes musculus

TURDIDAE

Platycichla flaviceps

Turdus leucomelas

Turdus rufiventris

Turdus albicollis

Turdus amaurochalinus

THRAUPIDAE

Trichothraupis melanops

Interior Borda Controle Total

12

3

2

9

26

13

4

12

\section{2}

98

1

1

5

27

1

1

1

12

1

1

2

106

37

4

2

3

\section{1}

$$
9
$$

2

45

79

1

98
16

30

5

4

13

C. 120

$\begin{array}{llll}26 & 15 & 11 & 52\end{array}$

4

$2 \quad 19$

26

2

2

11

3

$\begin{array}{cc}3 & 3 \\ 20 & 140\end{array}$

1

$\begin{array}{lll}7 & 8\end{array}$

$\begin{array}{llll}2 & 1 & 8\end{array}$

$\begin{array}{lll}7 & 7 & 34\end{array}$

1

1

23

$\begin{array}{lll}6 & 1 & 19\end{array}$

1

1

$3 \quad 3$

2

159

$\begin{array}{llll}37 & 9 & 19 & 65\end{array}$

2

3

3

2

$\begin{array}{llll}9 & 3 & 2 & 14\end{array}$

13

$\begin{array}{lll}2 & 40 & 85\end{array}$

$\begin{array}{llll}34 & 10 & 123\end{array}$

1

19
6
2
3
140
1
8
8
34
1
1
3
19




\section{Espécie}

Habia rubica

Tachyphonus coronatus

Thraupis cyanoptera

Pipraeidea melanonota

Stephanophorus diadematus

Tangara seledon

Tangara desmaresti

EMBERIZIDAE

Haplospiza unicolor

Volatinia jacarina

Sporophila lineola

Amaurospiza moesta

Tiaris fuliginosus

CARDINALIDAE

Saltator similis

PARULIDAE

Basileuterus culicivorus

Basileuterus leucoblepharus

Phaeothlypis rivularis

FRINGILLIDAE

Euphonia violacea

Euphonia pectoralis

\begin{tabular}{|c|c|c|c|}
\hline Interior & Borda & Controle & Total \\
\hline 19 & 1 & 26 & 46 \\
\hline 25 & 13 & 2 & 40 \\
\hline 1 & & & 1 \\
\hline \multirow[t]{3}{*}{2} & & & 2 \\
\hline & 1 & & 1 \\
\hline & & 2 & 2 \\
\hline 7 & & & 7 \\
\hline \multirow[t]{2}{*}{25} & 19 & 25 & 69 \\
\hline & 1 & & 1 \\
\hline \multirow[t]{2}{*}{1} & & & 1 \\
\hline & 1 & & 1 \\
\hline 1 & & & 1 \\
\hline 7 & 1 & & 8 \\
\hline 65 & 31 & 12 & 108 \\
\hline \multirow[t]{3}{*}{50} & 10 & & 60 \\
\hline & & 3 & 3 \\
\hline & & 4 & 4 \\
\hline 2 & & 1 & 3 \\
\hline
\end{tabular}

